\title{
With a little help from our friends
}

Citation for published version (APA):

Groen, G. A. M. (2020). With a little help from our friends: Exploring the transnational party activities of the German SPD, Die Linke and Bündnis 90/Die Grünen in the European Union. [Doctoral Thesis, Maastricht University]. ProefschriftMaken Maastricht. https://doi.org/10.26481/dis.20200424gg

\section{Document status and date:}

Published: 01/01/2020

DOI:

10.26481/dis.20200424gg

Document Version:

Publisher's PDF, also known as Version of record

\section{Please check the document version of this publication:}

- A submitted manuscript is the version of the article upon submission and before peer-review. There can be important differences between the submitted version and the official published version of record.

People interested in the research are advised to contact the author for the final version of the publication, or visit the DOI to the publisher's website.

- The final author version and the galley proof are versions of the publication after peer review.

- The final published version features the final layout of the paper including the volume, issue and page numbers.

Link to publication

\footnotetext{
General rights rights.

- You may freely distribute the URL identifying the publication in the public portal. please follow below link for the End User Agreement:

www.umlib.nl/taverne-license

Take down policy

If you believe that this document breaches copyright please contact us at:

repository@maastrichtuniversity.nl

providing details and we will investigate your claim.
}

Copyright and moral rights for the publications made accessible in the public portal are retained by the authors and/or other copyright owners and it is a condition of accessing publications that users recognise and abide by the legal requirements associated with these

- Users may download and print one copy of any publication from the public portal for the purpose of private study or research.

- You may not further distribute the material or use it for any profit-making activity or commercial gain

If the publication is distributed under the terms of Article $25 \mathrm{fa}$ of the Dutch Copyright Act, indicated by the "Taverne" license above, 


\section{With a little help from our friends}

Exploring the transnational party activities of the German SPD, Die Linke and Bündnis 90/Die Grünen in the European Union

Afke Groen 
(C) copyright Afke Groen, Maastricht 2020

ISBN: 978-94-6380-796-8

Cover: Simone Golob

Printing: ProefschriftMaken

All rights reserved. No part of this publication may be reproduced, stored in a retrieval system or transmitted, in any form or by any means, electronic, mechanical, photocopying, recording or otherwise, without prior permission of the author or the copyright-owning journals for previously published chapters. 


\section{With a little help from our friends}

Exploring the transnational party activities of the German

SPD, Die Linke and Bündnis 90/Die Grünen in the European Union

\section{PROEFSCHRIFT}

ter verkrijging van de graad van doctor aan de Universiteit Maastricht, op gezag van de Rector Magnificus, Prof.dr. Rianne M. Letschert volgens het besluit van het College van Decanen, in het openbaar te verdedigen op vrijdag 24 april 2020 om 12.00 uur

door

Gertrude Afke Maria Groen 


\section{Promotores}

Prof. dr. Christine Neuhold

Prof. dr. Tannelie Blom

\section{Copromotor}

Prof. dr. Ton Nijhuis

\section{Beoordelingscommissie}

Prof. dr. Esther Versluis (voorzitter)

Dr. Anna Herranz-Surrallés

Dr. Mendeltje van Keulen, De Haagse Hogeschool

Prof. dr. Michael Shackleton

Prof. dr. Wolfgang Wagner, Vrije Universiteit Amsterdam

Dit proefschrift is tot stand gekomen met dank aan financiële steun van het Duitsland Instituut Amsterdam (DIA). 


\section{Table of contents}

List of tables $\quad \mathrm{V}$

List of figures vii

List of abbreviations $\quad$ ix

Acknowledgements $\quad$ xiii

$\begin{array}{ll}\text { Introduction } & 1\end{array}$

Setting the scene: National parties and democracy in the European Union 1

The puzzle of transnational party activities of national parties in the European Union 2

Central questions and focus of the dissertation 3

A resource-dependence approach to political parties as transnational actors 6

Design of the empirical study $\quad 8$

$\begin{array}{ll}\text { Structure of the dissertation } & 10\end{array}$

\section{Part I Analytical and theoretical points of departure}

Chapter 1 | The 'playing field': Avenues for transnational party activities in the multi-level European Union

1.1 National parties as transnational actors in the European Union 16

1.2 | Europarties: Historical development and organisational structures 20

1.3 Relations between national parties and political groups in the European Parliament $\quad 24$

1.4 | Processes towards the institutionalisation of inter-parliamentary cooperation 28

1.5 Organisational structures for international cooperation of national parties themselves $\quad 35$

1.6 | Conclusion: The 'multi-level playing field' for national political parties 36

\section{Chapter 2 | State of the art: Transnational party and inter-parliamentary} cooperation in the European Union

2.1 Early debates: What role should parliaments play in the European Union?

2.2 Early 2000s: Studies on institutional (dis)functioning of parliamentary scrutiny and inter-parliamentary cooperation 
2.3 After Lisbon: Studies on the dynamics of parliamentary scrutiny and interparliamentary cooperation

2.4 Lacuna in the literature on national parliaments and inter-parliamentary cooperation

2.5 | After the 1979 direct elections: Studies on the emergence and development of Europarties

2.6 Early 2000s: Studies on the Europeanisation of national parties and the consolidation of Europarties

2.7| Studies on actual transnational activities of Europarties and national parties

2.8 Lacuna in the literature on European and national parties in European integration

2.9 Conclusion and contribution to the academic debate

Chapter 3 | Theoretical framework: A resource-dependence perspective on transnational party activities in the European Union

3.1 | Why this theoretical approach to transnational party activities? 64

3.2 | The basics of Resource Dependence Theory 67

3.3 | Party organisation, behaviour and ideology 74

3.4 | Resource dependencies of national political parties in the European Union 79

3.5 | Setting out expectations: Under what conditions do parties seek transnational contacts?

Chapter 4 | Research design: Methods, case selection and data

4.1 | Research approach: An exploratory strategy

4.2 Operationalising transnational party activities, resource dependencies and systemlevel conditions

4.3 | Case selection

4.4 Data analysis and data collection

\section{Part II | Practices of transnational party cooperation in the EU}

Chapter 5 | Transnational party activities with a view to the European Union Naval Force Mediterranean

5.1 Potential avenues for transnational party activities in European security and defence policy

5.2 What drives and what conditions transnational party activities in the context of

EU military operations? 
5.3 | The German contribution to operation EUNAVFOR Med

5.4 Transnational party activities of German parliamentary parties on operation EUNAVFOR Med

5.5 | Comparative analysis

Chapter 6 | Transnational party activities in the context of campaigning for national and European elections

6.1 Potential avenues for transnational party activities in campaigns for national and European elections

6.2 What drives and what conditions transnational party activities in the context of national and European election campaigns? 157

6.3 | The German Bundestagswablen and Europawablen between 2013 and 2019

6.4 | Transnational party activities on national and European campaigns 164

6.5 | Comparative analysis 181

\section{Part III | Discussion and conclusion}

\section{Chapter 7 | Synthesis and theoretical reflection}

7.1 Synthesis of the findings in light of the resource-dependence perspective on transnational party activities in the EU

7.2 Theoretical reflection: Other approaches to transnational party activities in the $\mathrm{EU}$ in light of the resource-dependence perspective

\section{Conclusion}

With a little help from our friends: Why national parties (don't) engage in transnational party activities in EU affairs 204

Limits, potentials and threats for transnational party activities in the EU 205

Directions for future research on transnational party activities in the EU 207

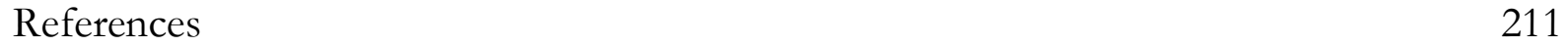

Annex 1 | List of interviews by case study 243

$\begin{array}{ll}\text { Samenvatting } & 245\end{array}$

$\begin{array}{ll}\text { Valorisation addendum } & 249\end{array}$ 



\section{List of tables}

Table 1 | Avenues for transnational party activities in the European Union 18

Table 2 | Development of Treaty articles and EC/EU regulations on Europarties 22

Table 3 | Overview of establishment of political parties at the European level ('Europarties')

Table 4 | Overview of institutionalised forms of inter-parliamentary cooperation in the European Union

Table 5 | Overview of administrative infrastructure for inter-parliamentary cooperation in the European Union

Table 6 Overview of the academic debate on national parliaments and interparliamentary cooperation in the European Union

Table 7 Overview of the academic debate on Europarties and national parties in European integration

Table 8 | Main expectations about the resource dependencies that motivate transnational party activities (by party goal and level of governance)

Table 9 | Main expectations about the system-level factors that condition transnational party activities (by party goal)

Table 10 | Different manifestations of formal and informal transnational party activities based on the interpretation of interviewees

Table 11 | Opposition/government status of parties in the Bundestag, 1990-2017

Table 12 | Case studies in relation to the resource dependencies of the theoretical framework

Table 13 | Frame of reference for the 'scoring' of transnational party activities

Table 14 | Strategy of case analysis per chapter

Table 15 | Number of interviewees per dossier and case study

Table 16 | Policy-seeking and resulting resource dependencies between parliamentary parties at the national and EU level

Table 17 | Resource dependencies and the transnational party activities of the SPD, the Left and the Greens with a view to EUNAVFOR Med

Table 18 | Vote and office-seeking and resulting resource dependencies between parties at the national and EU level

Table 19 | Vote shares and lead candidates in national and European elections in Germany (2013-2019) 
Table $20 \mid$ Resource dependencies and the transnational party activities of the SPD, the Left and the Greens with a view to Bundestagswablen and Europawablen

Table 21 | Evaluating the main expectations about the resource dependencies that motivate transnational party activities when it comes to party goals at the national level 191 Table 22 Evaluating the main expectations about the resource dependencies that motivate transnational party activities when it comes to party goals at the European level

Table 23 | Evaluating the main expectations about the system-level factors that condition transnational party activities 


\section{List of figures}

Figure 1 | Number of Europarties, 1973-2018

Figure 2 | Development of platforms for inter-parliamentary cooperation in the European Union

Figure 3 | Summary of the theoretical argument of what drives transnational party activities

Figure 4 | Seat shares in the Bundestag, 1990-2017

Figure 5 | Annual income and equity of the SPD, Greens and the Left, 2002-2017 104

Figure 6 | Distribution of general ideological positions of the Green, Radical left and Socialist EU party families, 2014

Figure 7 | Distribution of positions towards European integration and left/right positions of the Socialist, Green and Left EU party families, 2014

Figure 8 | Distribution of positions towards EU foreign and security policy of the green, radical left and socialist party families, 2014

Figure 9 | Distribution of positions towards international security and peacekeeping missions of the green, radical left and socialist party families, 2014

Figure 10 | Distribution of positions towards troop deployment and left/right positions of the Socialist, Green and Left EU party families, 2014

Figure 11 | Key decisions on EUNAVFOR Med at EU and German level, April 2015June 2018

Figure 12 Annual spending in euros (millions) on campaigns SPD, the Left and the Greens from 2002-2017

Figure 13 | Distribution of positions towards EU integration of the green, radical left and socialist EU party families, 2014 



\section{List of abbreviations}

AfD

ALDE

$\mathrm{CDU} / \mathrm{CSU}$

CFSP

CHES

CHES

$\mathrm{CMC}$

COSAC

CSDP

DiEM25

DIP

EAC

EC

ECPRD

ECR

EEAS

EGP

Enhl.

EP

EPC

EPP

EU

EUNAVFOR Med

EWS

FDP

Fidesz

FvD

Greens/EFA

GroKo

GUE-NGL
Alternative für Deutschland (Alternative for Germany)

Alliance of Liberals and Democrats in Europe

Christlich Demokratische Union/Christlich-Soziale Union (German

Christian Democratic Union/Christian-Social Union)

Common Foreign and Security Policy

Chapel Hill Expert Survey

Chapel Hill Expert Survey

Crisis Management Concept

Conference of Parliamentary Committees for Union Affairs of

Parliaments of the European Union

Common Security and Defence Policy

Democracy in Europe Movement 2025

Dokumentations- und Informationssystem (Documentation and

Information system of the German Bundestag)

European Affairs Committee

European Community

European Centre for Parliamentary Research and

Documentation

European Conservatives and Reformists Group

European External Action Service

European Green Party

Enhedslisten - De Rod-Gronne (Danish radical left party)

European Parliament

European Political Cooperation

European People's Party

European Union

European Union Naval Force Mediterranean

Early Warning System (for the principle of subsidiarity)

Freie Demokratische Partei (German Free Democratic Party)

Fidesz-Magyar Polgári Szövetség (Hungarian national conservative party)

Forum voor Democratie (Dutch populist radical right party)

Group of the Greens/European Free Alliance (Greens/EFA)

Große Koalition (Grand Coalition)

Confederal Group of the European United Left-Nordic Green Left

High Representative of the Union for Foreign Affairs and 
ICM

IPC

IPC CFSP/CSDP

IPC SECG

IPEX

IR

JPM

JPSG

MEP

MP

MRCC

NGO

NPs

PD

PDS

PEL

PES

PESCO

PG

PRG

PRR

PS

PSC

PSOE

PvdA

QMV

RDT

S\&D

SAP

SEDE

SI

SP

SPD

SPÖ
Security Policy

Interparliamentary Committee Meeting

Interparliamentary Cooperation (field of studies)

Inter-parliamentary Conference for the Common Foreign and

Security Policy and the Common Security and Defence Policy

Inter-Parliamentary Conference on Stability, Economic

Coordination and Governance

InterParliamentary EU information eXchange

International Relations (field of studies)

Joint Parliamentary Meeting

Joint Parliamentary Scrutiny Group

Member of the European Parliament

Member of Parliament

Maritime Rescue Coordination Centre

Non-governmental organisation

National parliaments

Partito Democratico (Italian social democratic party)

Partei des Demokratischen Sozialismus (German Party of Democratic Socialism)

Party of the European Left

Party of European Socialists

Permanent Structured Cooperation

Parti de Gauche (French radical left party)

Parti radical de gauche (French radical left party)

Populist Radical Right

Parti Socialiste (French social democratic party)

Political and Security Committee

Partido Socialista Obrero Español (Spanish social democratic party)

Partij van de Arbeid (Dutch social democratic party)

Qualified Majority Voting

Resource Dependence Theory

Socialists \& Democrats Group

Sveriges socialdemokratiska arbetareparti (Swedish social democratic party)

Subcommittee on Security and Defence in the European

Parliament

Socialist International

Socialistische Partij (Dutch radical left party)

Sozialdemokratische Partei Deutschlands (Social Democratic Party of Germany)

Sozialdemokratische Partei Österreichs 
SWP

Syriza

TFEU

TSCG

US

VIHR

WASG

WEU

ZIF
Stiftung Wissenschaft und Politik. (German Institute for International and Security Affairs)

Synaspismós Rizospastikís Aristerás (Greek radical left party)

Treaty on the Functioning of the European Union

Treaty on Stability, Coordination and Governance in the Economic and Monetary Union

United States

Vibreä liitto (Finnish green party)

Arbeit und soziale Gerechtigkeit - Die Wablalternative (German

Labour and Social Justice - The Electoral Alternative)

Western European Union

Zentrum für Internationale Friedeneinsätze (German Center for International Peace Operations) 



\section{Acknowledgements}

There is tendency in public debates to talk about politics in terms of nation states. And whether it is in the media or in academic pieces, most analyses report either on what happens at the national level or on what happens at the level of the European Union $(\mathrm{EU})$. It is this tendency that I have wanted to challenge in this dissertation. I have been fascinated with political parties ever since I was a young adult. I then became intrigued by transnational perspectives during my bachelor studies. And during my master studies, I developed a special interest in the EU. Working on this dissertation has thus been a great opportunity to bring together my favourite subjects: I set out to explore the transnational activities of national parties in the EU.

I could not have done so without the valuable contributions of the many party politicians and staff members who were willing to talk to me about their work. I am most grateful to them. My supervisors Christine Neuhold, Tannelie Blom and Ton Nijhuis have been indispensable. They gave me the opportunity to do a PhD. Their critical questions, luckily often accompanied with valuable advice, have also made this research project worthwhile. I want to extend a heartfelt thank you to them. Special thanks to Christine, for sparking my interest in parliaments and political parties, and to Tannelie, for sparking my interest in theory. Michael Shackleton was always willing to share his experiences and reflections on European affairs with me. I feel much indebted for this privilege. Thanks also to the Amsterdam Institute for German Studies (DIA) for financial support, without which this project would not have existed.

It has been highly valuable to present and discuss my work at multiple occasions. Many thanks to the participants and discussants at the 2016 DIA Graduiertenkolleg on Conflict and Cooperation in Europe in Amsterdam, the 2017 NIG Research Colloquium on International and EU Governance in the Hague, the 2018 ECPR General Conference in Hamburg, the 2019 Politicologenetmaal in Antwerp, and to my former colleagues in the Politics and Culture in Europe research group in Maastricht. I am particularly grateful to Wolfgang Wagner and Tapio Raunio for inviting me to their workshop on Party Politics of Foreign and Security Policy in Europe in Amsterdam in October 2017. They provided the constructive feedback and support necessary to prepare my article as part of their special issue for Foreign Policy Analysis. And thanks to the teachers at the Netherlands Institute of Government (NIG). I did not only profit from their courses, but also from the experience of questioning and being questioned academically.

I wish to thank the fantastic people at the Faculty of Arts and Social Sciences (FASoS). Esther and Arjan, you gave me the opportunity to take up new responsibilities in the Bachelor in European Studies, which enriched my PhD experience. Patrick, you taught me how to relax after work, which enriched my experience even more. Johan, you were always willing to brainstorm about the next steps in my project. I very much enjoy the side-projects with the both of you on teaching and learning. Aneta and tante Pia, thank 
you for showing me how to surf the waves. My building GG76 companions, and especially Christophe, Joeri, Marloes, Marie, Karlien, Floris, Sven, Dorina, Mayra, Vincent, Annelies, Jelena, Mirko, Maud, and Robin, you made life at FASoS enjoyable.

A most profound thank you to my students at Maastricht University; it has been such a joy to be your tutor and mentor. I know I have learned more from you than you from me. A special word of thanks to Nicolle. You made a vital contribution to this research project by joining me on fieldwork to Berlin.

The biggest thank you is to my friends and family. Dear parents, Rita and Ab, thank you for inspiring me with a love for learning and teaching. Dear brothers, Pieter and Jan Willem, thank you for distracting me with jokes and laughter. Dear Annemiek and Lammert, thank you for supporting me in finishing this dissertation. My dearest friends - in order of appearance in my life - Paola, Nienke, Jessy, Marloes, Pia, Patrice, Florentijn, Dirk-Jan, Simone, Tim, Philip, Anna-Lena, Mignon, Maike, and Maud, thank you for giving me the energy to finish this dissertation. I could not be happier that my two oldest friends will be my paranymphs. Madelon, you are the most amazing cheerleader. Lisa, you made every trip to Berlin a wonderful experience and miraculously kept me safe through autumn, winter, and spring storms. Anke and Tanya, the Feminist Fight Club, thank you for smashing the patriarchy on Wednesdays.

I am most grateful to my friendly giant, Gijs. Your boundless support has given me the courage to complete this book. Thank you, lief. 


\section{Introduction}

\section{Setting the scene: National parties and democracy in the European Union}

National political parties are crucial actors in democratic systems. By participating in elections, they are the most important organisations that link citizens to the institutions of the state. Parties need to respond to the preferences and demands of citizens. And, if they win elections, they need to channel such preferences and demands into proposals for government policies (Sartori, 2005[1976], p. 25). Fundamentally, then, in democratic systems, parties perform the function of "allowing the governed to express their demands freely and in such a way as to render them effective within the very machinery of government" (Sartori, 2005, p. 30). The performance of this function can, at heart, not be replaced by another institution, organisation, or group of actors (p. 28).

In a well-functioning representative democracy, also the policies of the European Union (EU) would ultimately be the result of the expression of citizens' preferences (Hix, Kreppel \& Noury, 2003, p. 310). The EU institutions take highly important policy decisions in many areas. From the area of foreign and security policy, in which they have limited, but special competences; to areas such as the internal market and regional policy, in which they share competences with the member states; and areas like trade, competition, and customs, in which they have exclusive competences. At the same time, member states retain competences to make legislation in other areas, including health and education. The EU is thus fundamentally a 'multi-level system': decisions are made both at the national, member state level and the supranational, EU level. These levels are inextricably linked to each other (Scharpf, 1994; 2001).

The democratic system of the EU is, however, particular. Most importantly, the "electoral connection" between citizens and parties at the European level is weak (Lindberg, Rasmussen \& Warntjen, 2008, p. 1108). Granted, the European Parliament (EP) has become an important, directly elected institution that has equal legislative powers to the Council of Ministers of the European Union (the Council) in many policy areas. It has asserted itself as an actor in EU politics that cannot be ignored (see e.g. Shackleton, 2017). Yet in essence, there are no 'real' political parties at the European level that select candidates to stand in elections, participate directly in societal debates, and 
compete over the office of the European Commission (Follesdal \& Hix, 2006, p. 535537).

In this absence, national parties continue to play a central role in the democratic system of the EU. They are the "vehicles" (Strøm \& Müller, 1999, p. 1) or " "transmission belts"' (Lindberg et al., 2008, p. 1107) between citizens and EU policies. In the media, national parties and politicians enjoy a much higher visibility to voters on EU affairs than politicians or other actors at the EU level (e.g. Boomgaarden et al., 2013). In national parliaments, national political parties perform a crucial democratic function by scrutinising EU affairs, and by justifying their positions to the public in plenary debates (e.g. Hefftler, 2018). And finally, national parties are in charge of the selection of candidates to run in elections to the European Parliament, as they compose the lists of national politicians whom voters can elect (e.g. Hix \& Hagemann, 2009).

\section{The puzzle of transnational party activities of national parties in the European Union}

Against this background of the continuing importance of national parties in the system of representative democracy of the EU, this dissertation explores the transnational party activities of national parties in the European Union. That is, the dissertation studies the interactions between national political parties across national borders, and across the national and supranational level of decision making. Such interactions potentially enhance the ability of national parties to be involved in EU affairs (e.g. Hefftler, 2015; Johansson, 2016; Miklin, 2013; Salm, 2016). In other words, through transnational party activities, national parties could pursue party goals "beyond domestic politics" (Senninger \& Bischof, 2018, p. 141).

Yet it is here that a puzzle emerges. On the one hand, national parties have strategic opportunities to engage in transnational party activities that arise from their various "access points" in the multi-level system of the EU (Ladrech, 2002, p. 400). National parties can, for example, seek to influence the actions and voting behaviour of their Members of the European Parliament (MEPs) (e.g. Faas, 2003; Mühlböck, 2012; Rasmussen, 2008; Senninger \& Bischof, 2018). MEPs can also be an important source of information and expertise on EU affairs (e.g. Aylott, Blomgren \& Bergman, 2013; Poguntke, Aylott, Carter, Ladrech \& Luther, 2007; Raunio, 2000). Moreover, national parties may be involved in setting the political priorities of Europarties (e.g. Klüver \& Rodon, 2012; Külahci, 2010). And they can meet and liaise with sister parties at interparliamentary conferences that bring together parliamentarians from all EU member states (e.g. Gattermann, 2014). When national parties occupy government positions, their leaders may attend political family meetings between leading national and EU politicians, which are organised by Europarties ahead of meetings of the European Council (Delwit, Külahci \& Van de Walle, 2004). Seen in this context, engaging in transnational party activities comes with clear benefits for national parties. 
On the other hand, national parties face constraints in making use of such strategic opportunities. These constraints arise from organisational and political constellations in the domestic realm (Johansson, 1997, p. 220). For example, creating networks with parliamentarians in other countries requires the investment of much time and energy. When would the benefits of these networks outweigh the costs of establishing and taking part in them? More importantly, technical and complex EU policy issues are often not interesting or salient to voters (Saalfeld, 2005). How can national Members of Parliament (MPs) then explain to their national constituency that they invest time in transnational activities on EU affairs? Moreover, even in elections for the European Parliament, national parties compete on issues that are important mostly in the national realm (e.g. Reif \& Schmitt, 1980; Hix \& Marsh, 2011; 2007). The growth of Eurosceptic parties also presents established national parties with a political challenge (e.g. Meijers, 2017). So why would national parties invest time and money in the development of campaigns organised by Europarties? Seen in this context, engaging in transnational party activities in the European Union may not come naturally to national political parties - let alone to individual members of a national parliament.

Previous academic research shows how EU integration has had an - albeit limited - impact on the organisational structures of national political parties and on the development of European political parties (e.g. Aylott et al., 2013; Pogutnke et al., 2007). Research also shows how political parties both at the national and European level have strategically and ideologically positioned themselves on EU affairs (e.g. Bakker et al., 2015; Hix, 2002; Hooghe et al., 2002; McElroy \& Benoit, 2007; Rohrschneider \& Whitefield, 2016). Some scholars, moreover, explore the functioning of formal platforms for interaction between party actors across national borders and levels of governance, such as in Europarties (e.g. Bressanelli, 2014; Johansson, 2016; Külahci, 2010) or at interparliamentary conferences (Crum \& Fossum, 2013a; Fromage, 2016; Herranz-Surrallés, 2019). Yet the regular, more informal, transnational party activities of national parties, as well as the importance of these activities for the political activities of national parties, remain largely unexplored.

\section{Central questions and focus of the dissertation}

The central aim of the dissertation is to answer two research questions, namely 1) what drives transnational party activities of national political parties in European Union affairs? and 2) under what conditions do national political parties engage in transnational party activities in European Union affairs? The rationale for having two questions is that the dissertation seeks to explore transnational party activities both from an actor perspective and from a system perspective. In other words, the first question asks about the intrinsic motivations of national parties to engage in transnational interactions with other parties across borders. Why do parties do what they do in the first place? The second question, then, asks about 
the system-level factors in the domestic or European realm that impact on these motivations. What settings or circumstances affect the choices of parties?

To explore the viability of the theoretical arguments, I conduct a comparative case study of the practices of the three German political parties on the left of the political spectrum with seats in the eighteenth German federal parliament, the Bundestag (20132017). These parties are the social democratic Sozialdemokratische Partei Deutschlands (SPD), the green Bündnis 90/Die Grünen (the Greens) and the radical left Die Linke (the Left). The dissertation focuses on the transnational activities of the parties in parliamentary office and the parties in central office. I investigate transnational party activities with a view to two major issues, namely the controversial EU military operation to combat human trafficking in the Mediterranean Sea, known as EUNAVFOR Med, that was launched in April 2015; and the election campaigns for the elections to the European Parliament of 2014 and 2019, and the elections to the national Bundestag of 2013 and 2017. The research most importantly draws on qualitative data from forty semi-structured interviews with politicians and staff members.

The empirical findings of this dissertation contribute to three bodies of academic literature. First, the findings of this dissertation speak to the literature on Europarties and inter-parliamentary cooperation. In particular the literature on inter-parliamentary platforms for cooperation has increased since the entry into force of the Lisbon Treaty (e.g. Crum \& Fossum, 2009; 2013; Lupo \& Fasone, 2016; Raube, Müftüler-Baç \& Wouters, 2019), while also attention to Europarties has expanded (e.g. Bressanelli, 2014; Gómez-Reino, 2018; Hanley, 2008; Lightfoot, 2006; Van Hecke, 2010). There is evidence that both platforms are relevant to national parties, mostly because they facilitate the exchange of information, experiences and ideas (e.g. Miklin, 2013; Malang, 2019; Von dem Berge \& Poguntke, 2012). In particular Europarties also facilitate the development of collective positions (e.g. Klüver \& Rodon, 2012) and they may even serve as a platform to influence EU negotiations (e.g. Johansson, 2016; Van Hecke, 2012). At the same time, scholars emphasize the limits to such functions. These are, for example, the result of differences in the domestic contexts of parties and parliaments, and the weak formal powers of Europarties and inter-parliamentary conferences (see e.g. Crum \& Fossum, 2013a, p. 3; Johansson, 2017; Raunio, 2009, p. 322-325).

Despite the limited empirical insights into, and the mixed evidence about, the added value of inter-parliamentary conferences and Europarties, scholars are often optimistic about the future relevance of both platforms (e.g. Crum \& Fossum, 2013b; Hertner, 2011b, p. 344; Külahci \& Lighfoot, 2014, p. 81). This dissertation thus makes an important empirical contribution. Contrary to the vast majority of previous literature, it approaches transnational party activities in a "bottom-up" manner, exploring the choices national parties make (Hanley, 2008, p. 201). When do national parties indeed find the platforms of inter-parliamentary conferences and Europarties relevant to their work? If parties mostly rely on other networks or actors to acquire information and expertise, or to develop common positions, this would cast doubts on the usefulness of platforms for 
party and inter-parliamentary cooperation. It would also raise questions about the degree to which the transnational parliamentary and party forums may potentially address a lack of democratic involvement of political parties and parliaments in EU affairs.

Second, the answer to the questions about what drives and what conditions national parties to engage in transnational party activities is of relevance to debates about party politics and politicisation in the European Union. Research has well established that, across Europe, national parties from the same party family tend to hold similar views towards European integration (e.g. Bakker et al., 2015; Hooghe \& Marks, 2018; Hooghe, Marks \& Wilson, 2002; Marks \& Steenbergen, 2002; Prosser, 2016). Particularly liberal, social and Christian democratic parties show very high levels of cohesion in their support for European integration, while parties on the far left and right of the spectrum are generally opposed to integration (Bakker et al., 2015, p. 145). Even in the area of European foreign and security policy, in which party contestation is traditionally said to be unlikely due to the importance of national interests, scholars find that the policy positions of parties that subscribe to the same ideology tend to converge in a manner similar to general patterns of contestation about EU integration (e.g. Angelucci \& Isernia, 2019; Chryssogelos, 2015; Wagner, Herranz-Surrallés, Kaarbo \& Ostermann, 2017). Several scholars also show that political parties increasingly contest European issues in national debates, especially in the context of the euro and Schengen crises of the 2010s (e.g. Börzel \& Risse, 2018; De Wilde, 2011; Miklin, 2014; Rauh, 2015; Raunio, 2016; compare Green-Pedersen, 2012).

Such findings suggest that there is a transnational dimension to party politics in the EU when it concerns the contestation of European integration and affairs. Kinski and Crum (2019) show that there is a transnational dimension even to democratic representation in the EU. They find that, in national parliamentary debates, MPs speak not just for the interests of their national electorate, but also for the interest of foreign nationals. Nevertheless, very little is known about transnational contacts between national parties that may actively foster similar positions within party families or establish "networks of representative claims" (Kinski and Crum, 2019, p. 2). Do parties act across the levels of governance to organise political opposition or support? If national MPs and party officials have an incentive to engage in such transnational partisan activities, and if such activities are visible also in the domestic realm, this may support hopes for a more developed democratic opposition in the EU (e.g. De Wilde \& Zürn, 2012; Hefftler, 2018; Kröger \& Bellamy, 2016; Van Middelaar, 2016).

Third, and finally, the findings of this study can contribute to a better understanding of informal politics in the European Union. Both scholars working on policy making within EU institutions and scholars studying transnational networks in EU integration emphasize that the complex, interconnected system of governance in the EU provides for many opportunities to informally influence EU policies (Salm, 2016, p. 2; see also Börzel \& Heard-Lauréote, 2009; Kaiser, 2008; Reh, Héritier, Bressanelli \& Koop, 2011). In view of such opportunities, scholars particularly pay attention to informal 
networks of non-state actors (e.g. Haas, 1992; Keck \& Sikkink, 1999; Nye, 1974). But also in treaty negotiations and day-to-day decision making, preparatory groups often "precook" or even pre-decide the work of political leaders (Christiansen \& Neuhold, 2013, p. 1199-1200). For national parliaments, informal coordination is highly important in view of the Early Warning System for the principle of subsidiarity - a procedure that allows national parliaments to flag discontent with EU legislative proposals to the European Commission (p. 1200; see also Cooper, 2015).

Existing academic research has, however, barely explored the practices of national parties in this regard (for exceptions see e.g. Miklin, 2013; Salm, 2016). Do national political parties make use of the informal opportunities that the multi-level nature of EU decision making offers? Informal connections can prove important to parties. If opposition parties can informally acquire information from sister parties on a particular EU policy issue, they may be able to strengthen their position vis-à-vis the national government in the national parliament (Mello \& Peters, 2018; Miklin, 2013). And if national parties act transnationally to support or oppose particular EU issues, for example by informally aligning political positions or arguments, they may be able to influence European decision-making processes.

In chapter 2, I discuss the contribution of this dissertation in light of the specific literature on national parties and national parliaments in EU integration in more detail. In the conclusion, I return to the three overall bodies of literature mentioned in this introduction.

\section{A resource-dependence approach to political parties as transnational actors}

To understand the transnational activities of national parties in the European Union, I develop two theoretical arguments. Both theoretical arguments are based on Resource Dependence Theory (RDT). RDT was originally developed by Pfeffer and Salancik (2003[1978]) in their seminal work The External Control of Organizations. It is an organisational theory from the field of studies on private firms and management. Its fundamental proposition is that organisations engage in exchanges with external organisations to acquire the resources necessary for reaching their goals, while seeking to manage both the degree of their dependence on external actors and the social demands that external actors make. By extending the RDT approach to the study of national parties and their transnational activities, I contribute to the further conceptualisation of parliaments and parties as transnational actors in the European Union (Chryssogelos, 2017; Fonck, 2018).

Clearly, politics is a sub-system different from economics, and caution is required in 'translating' theoretical explanations from one field to another. The core logic of RDT, however, provides a powerful tool to sharpen academic understanding of the contacts of national parties across national borders and between levels of governance in the EU. 
First, much more than the approach of Europeanisation, which is dominant in the study of national parties and the EU, RDT provides a solid theoretical basis to understand the active response of national parties to strategic opportunities in the EU. This is because the primary aim of RDT is to theorise about how organisations respond to and manage pressures from their environment, while the primary aim of Europeanisation is to conceptualise the EU as a "stimulus" for change in organisations (Ladrech, 2012, p. 576). RDT is hence more sensitive to the motives that underlie the choices that organisations make, as well as to external pressures other than those arising from the EU to which organisations respond.

This characteristic of RDT contributes to a better understanding of the first research question that this dissertation seeks to answer, namely about what drives transnational party activities of national parties in the EU. My first theoretical argument hence pertains to this first research question and concerns the cause of transnational party activities. In brief, I argue that political parties in the European Union face resource dependencies and that they establish contacts with like-minded parties to manage these dependencies. I identify three sets of resource dependencies, namely resource dependencies related to vote-seeking, to office-seeking, and to policy-seeking behaviour at the national and EU level.

Second, and contrary to the International Relations (IR) approach to transnationalism that focuses on the analysis of transnational networks as such, RDT allows for the integration of insights about domestic politics from Comparative Politics (CP). This is crucial. As Johansson (2004, p. 34) writes, "the remaining and major challenge to future analyses of European party politics [...] is to define and identify the conditions and circumstances under which political parties are able to act on a multilevel and European basis". An attempt to tackle this challenge requires a consideration of the domestic political constellations that constrain and motivate national parties to engage in transnational activities (p. 26). RDT is well-suited to integrate insights from other (sub)disciplines to conceptualise the "acceptable outcomes" that organisations pursue in view of their particular environmental setting (Pfeffer \& Salancik 2003[1978], p. 11; see also Beyers \& Kerremans, 2007, p. 463-464). Previous considerations of RDT beyond management studies also illustrate this, such as in research on interest groups in the EU (Beyers \& Kerremans, 2007; Bouwen, 2002).

This suitability contributes in particular to a better understanding of the second research question of this dissertation, which asks about the conditions under which national parties engage in transnational activities. The second theoretical argument relates to this question and is about the degree to which national parties engage in transnational party activities. My core argument is that three sets of system-level conditions that are important, namely 1) the position of a party in the national political system, 2) the existence of (alternative) routes to obtain resources, and 3) the ideological coherence of the party family. 
A final note about the focus of this dissertation on the party in parliamentary office and the party in central office is necessary. Katz and Mair (1993) famously distinguish "three faces of party organisation" (p. 601). These are the party on the ground, which is made up by party members, activists and loyal voters; the party in central office, which consists of the executive and central party bureau; and the party in public office, which is the party "in government and in parliament" (Mair, 1994, p. 4). Although I recognise that parties on the ground can and do maintain connections across borders, I focus on the faces of party organisation at the national level. This is not only because these parts of the party organisation are most importantly involved in EU affairs (e.g. Poguntke, Aylott, Ladrech \& Luther, 2007, p. 750-752), but also because they are most visible to citizens in national and European elections.

With regard to the party in public office, I focus on the party in parliament, which I refer to as the 'party in parliamentary office'. The few existing studies on transnational party activities of national parties focus mostly on party leaders and elites associated with the party in government office (e.g. Gehler, 2010; Johansson, 2017). This is problematic in view of the alleged problem of "executive bias" in the European Union, which refers to the idea that "national office is the most important entry point to decision making at the European level" (Poguntke et al., 2007, p. 750). As a result, governments enjoy an informational advantage both over their own backbenchers (e.g. Ladrech, 2007) and over the parliamentary opposition (Norton, 1996, p. 6-7; Raunio, 1999a, p. 180-181). The potential importance of transnational activities for actors from the party organisation in parliament hence remains little understood (see Miklin, 2013; Van Hecke, 2012, p. 845847).

\section{Design of the empirical study}

The empirical study of transnational party activities in the European Union follows an exploratory strategy. This strategy is warranted given that the transnational party activities of national parties in the European Union are under-researched both empirically and theoretically, but also given that the context to transnational party activities is still very much in flux (see also Hanley, 2008, p. 5-6). An important implication of the exploratory strategy is that the inquiry is explicitly a tentative one. I aim to provide a first insight into the phenomenon of transnational party activities. Hence, the study is the result of a research process in which I recurrently went back and forth between empirical data and theoretical propositions (Toshkov, 2016, p. 33).

Case studies are particularly suitable for such exploratory research, because they allow for rich contextual insights into the behaviour, motives and environment of relevant actors (Gerring, 2004, p. 349-350). I study the phenomenon of transnational party activities through a comparative case study of the practices of the German national parties SPD, the Left and the Greens. These three German political parties provide excellent cases for the exploratory inquiry into transnational party activities in the European Union, 
because they are substantively important cases. It is particularly noteworthy that the parties have historically been dominant in transnational politics in the European Parliament (Pridham \& Pridham, 1981, p. 155) and play a crucial role in existing transnational party networks, including most notably the Europarties (Hanley, 2008, p. 206; Klüver \& Rodon, 2012). The centrality of Germany in EU decision making furthermore means that the parties have a "superior importance" to national parties in other EU member states (Chiochetti, 2017, p. 8). Hence, because it is important to "[get] the 'big' cases right"' in the development of theoretical approaches (Mahoney \& Goertz, 2006, p. 243), it is highly important to consider the German parties.

Moreover, on the one hand, the similarity of the three German, left-wing parties allows for managing many potentially intervening factors. On the other hand, the variation between the SPD, the Greens and the Left allows for exploring the plausibility of my theoretical arguments: the parties differ with respect to the three system-level conditions that the theoretical framework identifies.

To study the actual transnational party activities of the three German parties with a view to policy-seeking, the EU military operation European Naval Force Mediterranean (EUNAVFOR Med) is particularly interesting. The operation has been highly controversial and Germany has been a central actor during its various phases. This makes it reasonable to expect relatively high levels of scrutiny and control of the operation. Moreover, EUNAVFOR Med is part of the EU's Common Foreign and Security Policy/Common Security and Defence Policy (CFSP/CSDP), in which decision making is in the hands of governments to a much greater extent than in other EU policy areas. Involvement of political parties would hence also be normatively important, given debates about the democratic legitimacy of decision making in this area (e.g. Kesgin \& Kaarbo, 2010; Mello \& Peters, 2018; Raunio \& Wagner, 2017; Wagner, Herranz-Surrallés, Kaarbo \& Ostermann, 2017). These debates are also highly prominent in Germany, given the country's complicated constitutional regime on troop deployments that emerged after World War II (see e.g. Peters, 2018).

Regarding transnational party activities with a view to vote-seeking and office-seeking, the two elections to the Bundestag and two elections to the European Parliament between 2013 and 2019 provide a rich context. During this period, the electoral challenge from the radical right grew substantially, while the social democratic centre-left saw a general decline. Moreover, the 2014 European elections for the first time saw the election of Europarty lead candidates to run for Commission President - a procedure known as the 'Spitzenkandidaten' process. The electoral challenges and the Spitzenkandidaten experiment make it reasonable to expect relatively more interest in contacts and coordination with sister parties in view of election campaigns.

Empirically, the dissertation most importantly draws on semi-structured interviews with German MPs and staff members concerned with security and defence in the Bundestag, staff members in central party offices responsible for election campaigns, and other EU experts of the German parties (see annex 1 for a complete overview). I 
triangulate the information obtained from interviews with interviewees in other EU member states or in the Europarties, with official documents and publications of the three German parties, and with press releases of MPs. I also rely on official EU documents, and on publications of the Europarties and the Bundestag to reconstruct decision-making processes.

\section{Structure of the dissertation}

The dissertation consists of three parts. Part I provides the empirical and theoretical starting points for the analysis of transnational party activities in the EU. Chapter 1 conceptualises national parties as transnational actors in the European Union. It takes stock of existing structures for cooperation between political parties and between parliaments in the European Union, and briefly addresses their historical development. Ultimately, the aim of the chapter is to provide the context to the analysis of the choices that political parties make in engaging in transnational contacts. The description illustrates the potential significance of transnational party activities, and the empirical complexity of the field also provides an additional justification to study the choices and behaviour of political parties.

Chapter 2 reviews existing academic literature about transnational parliamentary and party cooperation in the EU. It contextualises the focus and findings of this literature by also reviewing the broader academic debates about national parliaments in the EU and the effect of European integration on national parties. Hence, the chapter reviews research on national parliaments and EU affairs and the adjacent literature on interparliamentary cooperation, and reviews research on national parties and European integration and the adjacent literature on Europarties. I argue that the study of transnational parliamentary and party cooperation lacks an empirical focus on informal transnational party activities; a theoretical perspective to understand the behaviour and incentives of national parties to engage in transnational activities; and a methodological focus on individual actors and particular areas of cooperation.

Chapter 3 presents the resource-dependence perspective on transnational party cooperation in the European Union. It reviews what the Resource Dependence Theory of Pfeffer and Salancik (2002[1978]) adds to existing approaches that aim to understand the response of national parties to European integration and discusses how the theory relates to the sub-disciplines of International Relations and Comparative Politics. The chapter then goes on to present the basics of RDT, as well as of theoretical approaches to party organisation and party behaviour. The final two sections of the chapter present the twofold theoretical argument about what drives transnational party activities in the EU and what conditions such activities.

Chapter 4 sets out the research design of the empirical study. It discusses the nature of the exploratory study and the choices made in the research design of the empirical study in further detail. The chapter also sets out the justification for the case 
study of the three left-wing German parties. To do so, the chapter draws on data from the Chapel Hill Expert Survey (CHES), the ParlGov database, and the financial accounts of the German parties to map differences between the SPD, the Left and the Greens. The last section of the chapter discusses the processes of data gathering and data analysis.

Part II of the book contains the empirical analysis of practices of transnational party cooperation by the German SPD, the Greens and the Left. Chapters 5 and 6 present the analyses of the two dossiers of transnational party activities to examine the actual behaviour and choices of the three German parties. In chapter 5, I compare the transnational party activities of the three German parties with a view to EUNAVFOR Med. In chapter 6, I compare the transnational party activities of the parties with a view to election campaigns for the two national elections and two elections to the European Parliament between 2013 and 2019. Both chapters first present some more specific theoretical expectations about transnational party activities in the respective area under investigation. These expectations are derived from the resource-dependence perspective presented in chapter 3 . The chapters then present the findings of the exploratory research on the three political parties. They conclude with a comparison of the findings with respect to the causes and degree of transnational party activities.

Part III of the book provides the discussion and conclusion. Chapter 7 synthesises the findings of the two dossiers of transnational party activities. It triangulates these findings with previous research on transnational party cooperation and interparliamentary cooperation. The chapter then reviews the plausibility of the theoretical framework. I argue that the importance that political parties ascribe to transnational party activities on a particular EU dossier is conditioned most importantly by the political position that parties occupy with regard to that dossier within the national political system. Finally, the conclusion presents a brief summary of the findings, discusses the normative implications of the findings, and outlines several directions for future research. 

Part I

\section{Analytical and theoretical points of departure}





\section{Chapter 1}

\section{The 'playing field' \\ Avenues for transnational party activities in the multi-level European Union1}

The aim of this first chapter is twofold: to conceptualise national parties as transnational actors, and to identify the avenues through which transnational cooperation between parties in the multi-level system of the European Union (EU) can take place. In so doing, the chapter also provides important background information for understanding the theoretical argument and the empirical material of the dissertation. In line with the focus of the dissertation, I put the spotlight on avenues for cooperation of the party in central office and the party in parliamentary office: what structures and means for transnational cooperation for national parties exist in the EU?

To answer this question, I analytically distinguish between four avenues for transnational party activities in the EU: 1) The European political party federations (commonly referred to as Europarties); 2) the political groups in the European Parliament (EP); 3) the various platforms for inter-parliamentary cooperation; and 4) organisational structures for transnational cooperation of national parties themselves. Chapters 5 and 6 return to these avenues for transnational activities in the specific context of the cases under scrutiny, namely the field of foreign and security policy and national and European election campaigns.

The chapter shows that the number of platforms, conferences, meetings and tools for party and parliamentary cooperation has grown substantially over the years. The result

1 Part of the material of this chapter is published in Christiansen, T. \& Groen, A. (2018). Interparliamentary cooperation in the European Union: Towards institutionalization? In K. Raube, M. Muftuler-Bac \& J. Wouters (Eds.), Parliamentary Cooperation and Diplomacy in EU External Relations (pp. 29-52). Cheltenham: Edward Elgar. This especially concerns sections 1.2 and 1.4. 
seems to be a myriad of different platforms with diverging purposes and memberships, not least because various avenues for cooperation are interconnected. The presence of these various avenues for cooperation points to the potential significance of transnational contacts between parties, while the complexity of the emerging picture provides an additional justification to study the choices and behaviour of national parties in the field.

I first conceptualise national parties as transnational actors in the EU, and then review the development and nature of the four avenues for cooperation. Because the workings and nature of these avenues can best be understood against the background of their historical development and of broader developments in European integration, I also provide the necessary historical context. I conclude by discussing the complexity of the emerging picture. I draw on a combination of information obtained from secondary and primary sources, including some interviews.

\subsection{National parties as transnational actors in the European Union}

The first question that needs an answer is how a national party can in fact be a transnational actor. Clearly, national parties are first and foremost national actors: they are very often funded by state subsidies, their work is by far and large focused on the institutions of the state, and they compete for votes of the national electorate. But notwithstanding the territorial and organisational foundation of national parties at the level of the national state, national parties are not bound to act only within the limits of the state in which they are founded (Mittag, 2011, p. 6; Salm, 2016, p. 3). They can act across borders and across levels of governance, and as such, interact with (party) actors in other countries. As Johansson (2004) writes, parties can be understood as "linkage actors [as] they operate across levels and they are important, perhaps the most important, political actors in a polity" - including the polity of the EU (p. 19).

In this dissertation, national parties are understood as transnational actors whenever they interact across national levels, or across the national and European level. Thus, and in contrast to most studies on transnationalism in the field of International Relations (IR) (e.g. Haas, 1992; Keck \& Sikkink, 1999), I understand the term 'transnational' to not only refer to those actors that are organisationally detached from states. Instead, I employ the term to denote the actual behaviour of actors (Kaiser \& Starie, 2005 , p. 5). National parties are considered to be transnational actors in their own right in so far as they have the ability to engage in transnational interactions (see also Chryssogelos, 2017, p. 258-260; Fonck, 2018, p. 1307). Transnational party activities, then, are understood as any form of interaction between political parties across borders or levels of governance (see also Miklin, 2013, p. 26).

As the introduction sets out, the focus of this dissertation, and thus of this chapter, is on transnational activities of the party in central office and in parliamentary office. Potential avenues for cross-national activities of the party in government office and of the party on the ground are thus outside the scope of this dissertation, and not 
further discussed. For the party in government office, avenues for cooperation would overlap those of the party in parliamentary office, but would further include various kinds of international meetings of government officials to which parties in parliamentary office do not have access. For the party on the ground, avenues for transnational activities would also include partnerships with local or regional activists abroad, particularly in border regions or Euregions.

\section{Four avenues for transnational party activities in the European Union}

The EU's institutional framework provides several "opportunity structures" that may prompt and facilitate parties to act transnationally (Van Hecke, 2010, p. 409). The political groups in the European Parliament are the most institutionalised example of this. Yet they are only one of several avenues through which national parties can act transnationally. Indeed, in the multi-level system of the European Union, policies are developed in an interplay between the national and supranational level, which creates opportunities for parties to act across these levels. Because decision-making processes are often also highly informal, national parties have many "access points" for transnational cooperation (Salm, 2016, p. 2).

In this context, there are four avenues through which national parties can act transnationally in the EU.2 Table 1 summarises these avenues. First, transnational cooperation can occur through the Europarties. Europarties are party organisations at the supranational level that bring together national parties from the same ideological party family. The oldest, most developed, and well-known Europarties are the Christiandemocratic and conservative European People's Party (EPP), the social democratic and Socialist Party of European Socialists (PES), the liberal and centrist Alliance of Liberals and Democrats in Europe Party (ALDE), and the Green European Green Party (EGP) (Van Hecke, 2010, p. 399-400). Some of these parties originate from long-standing international party organisations such as the Socialist International (SI), and several Europarties maintain close ties to these international party organisations.

Second, the political groups in the EP can be an avenue through which transnational cooperation between parties takes place. The political groups are the parliamentary groups of the European Parliament. In these groups, parties from different member states that ascribe to a similar ideology act together in decision making about EU policies (e.g. Hix, Noury \& Roland, 2007; compare Bowler \& McElroy 2015). They are crucial in the organisation and daily work of the Parliament. The interaction between Members of the European Parliament (MEPs) from various member states is usually only located at the supranational level - that is, within the EP itself. Nevertheless, EP political groups occasionally organise meetings that also involve national parliamentarians (MPs), for example about particularly salient issues (e.g. Miklin, 2013, p. 31). Moreover, many

2 See chapter 4, section 4.2, for a brief reflection on how I identified these avenues, and for an overview of how interviewees interpreted formal and informal contacts. 
national parties engage in regular contacts with MEPs from their own national party delegations in the EP (Miklin \& Crum, 2011; Mühlböck, 2012). Although cooperation with the national delegation in the EP does not cut across a national border, it does transcend different levels of decision making.

Third, transnational party activities can take place at inter-parliamentary conferences. Inter-parliamentary conferences bring together MPs and MEPs, usually from particular parliamentary committees. The Conference of Parliamentary Committees for Union Affairs of Parliaments of the European Union (COSAC), for example, brings together representatives from the various committees for European Union affairs, while the Interparliamentary Conference on the CFSP/CSDP (IPC CFSP/CSDP) brings together representatives from defence and foreign affairs committees. Although these platforms are designed along national delegations, national parties can and do use it to seek cooperation along the lines of sister parties (Gattermann, 2014; Miklin, 2013, p. 37). Indeed, the largest EP political groups also facilitate party family meetings on a regular basis at the various inter-parliamentary conferences.

Fourth, national parties can engage in direct contacts with national parties in other member states through their own organisational structures for transnational cooperation. National parties have, for example, often appointed or elected international secretaries who are responsible for maintaining international contacts. These international secretaries maintain close transnational networks, and also play an important role in maintaining contacts with Europarties and other international party organisations (see e.g. Salm, 2016). Some, mostly larger, national parties additionally maintain departments for international affairs. These organisational structures facilitate regular transnational exchanges, which can range from informal, bilateral phone calls to conferences that bring together several parties.

Table 1 | Avenues for transnational party activities in the European Union

\begin{tabular}{ll} 
Location of the avenue & $\begin{array}{l}\text { Actors through and with which national parliamentary } \\
\text { parties can engage in transnational party activities }\end{array}$ \\
\hline Supranational level & Europarties* \\
& European Parliament political groups \\
& Inter-parliamentary conferences \\
& European political foundations** \\
National level & National political foundations** \\
& National party organisational structures
\end{tabular}

* Some authors position Europarties at the 'transnational' level (e.g. Niedermayer, 1984; V an Hecke, 2010, p. 398). I locate them at the supranational level, however, because most Europarty secretariats are located in Brussels, and the Europarties are regulated and funded by the EU.

** Political foundations are not further considered in this dissertation.

It is important to recognise that also political foundations, and in particular the German political foundations, can play a significant role in facilitating transnational party activities. Political foundations are usually publicly financed, and they complement the work of 
political parties. For example, they contribute to debates about the development of policies, carry out analyses, organise conferences, meetings and workshops, and implement development policies. The German politische Stiftungen have the longest history: they date back to the Weimar Republic and further developed after 1945. After the end of the Cold War, the "model" of foundations "spread internationally" (Dakowska, 2009, p. 201), as new political foundations established themselves to promote democratic values. Such national foundations have played a fundamental role in facilitating transnational party exchange in the EU, most importantly in the process of enlargement. The German Stiftungen, for example, maintain close contacts with political and administrative elites abroad through their foreign offices and run projects with partner organisations in EU enlargement countries (on the European and global activities of the German foundations, see e.g. Brucker 2007; Dakowska, 2005; Pinto-Duschinsky, 1991; Weissenbach, 2010; for a comparative perspective, see e.g. Anheier, 2001; Scott, 1999).

At the European level, political foundations affiliated to the Europarties have received funding from the EU budget since 2008 (see Dakowska, 2009). Since then, most Europarties have established a European political foundation - although the political foundation of the Left, Transform!, was created in 2001 already. The European foundations mostly act as networks of national foundations, but they can also support the programmatic work of the Europarties (Gagatek \& Van Hecke, 2014, p. 96 and 101). Organisational linkages between European foundations and their respective Europarties are, for example, facilitated by the Executive Boards of foundations. These boards often include MEPs or leaders of Europarties, just like leading national party politicians often feature on the boards of national foundations.

Although I do recognise the importance of European and national foundations in organising, facilitating, and financing transnational party activities of the party in central or parliamentary office, I do not further discuss them in detail in this chapter. This is because political foundations are not party or parliamentary actors as such.

\section{Complexity and different types of transnational party activities in the European Union}

For analytical purposes, table 1 presents the different avenues for cooperation as separate from each other. The subsequent discussion of the four channels illustrates that they are in fact interlinked. For instance, EP political groups organise party family meetings in the fringe of inter-parliamentary conferences and representatives of national parties can arrange follow-up bilateral or multilateral contacts at Europarty meetings.

In all avenues, transnational party activities can be both formal and informal. Informal activities are based on informal rules of interaction, often involve a limited number of actors, have no final outcome, and are not publicly reported (Reh, Héritier, Bressanelli and Koop, 2013, p. 1115-1117). Informal exchanges and activities are particularly frequent in bilateral or multilateral contacts organised by national parties themselves. Other avenues, such as inter-parliamentary conferences, are based mostly on formalised formats for interaction. They can, however, be preceded by informal meetings 
around particular themes (Fromage, 2016, p. 757-763), and they can facilitate informal networking during social activities. Table 10 in chapter 4 of this dissertation presents a summary of the interpretation of 'formal' and 'informal' activities by the interviewees.

Finally, transnational party activities can have different degrees of complexity (Kuper, 2006, p. 93-94). That is, some activities only cross one level of governance and are thereby rather "simple" (p. 93). For instance, bilateral or multilateral transnational interaction between national parties only horizontally crosses national levels, while coordination between a national party and its national delegation in the EP party group only vertically crosses levels. Other activities are more "complex" (p. 93), as they consist of both horizontal and vertical interactions. Examples are an exchange between an MEP and a national party from another member state or coordination between two national parties in the context of a Europarty meeting. Lastly, some avenues for transnational cooperation can "reduce complexity", because they direct activities through a particular institutionalised platform. Inter-parliamentary conferences, for example, bring together MPs and MEPs from different member states (p. 94).

The following four sections review the four avenues to transnational party activities in more detail.

\section{2 | Europarties: Historical development and organisational structures}

\section{Historical development of the Europarties}

Europarties are the most obvious European platforms for cooperation between national parties. Attempts to facilitate cooperation between like-minded political parties existed well before the creation of the first European communities, namely in the form of international party organisations. The Socialist International (SI) is the most notable example of this. The roots of this world-wide network of Socialist, Social Democratic, and Labour parties date back to the 19th century (see Joll, 2014[1955]). Christian democratic parties established an organisation just after the First World War (see Papini, 1997), while liberal parties created the Liberal International after the Second World War (Smith, 1997). It was, however, the process of European integration that gave a major spur to cooperation between like-minded parties in Europe (Delwit, Külahci \& Van der Walle, 2004, p. 5).

The emergence of Europarties was neither instant nor linear. Instead, it can be observed in various 'waves', both in terms of the role and importance of Europarties, and in terms of the number of Europarties (Hix, 1996; Van Hecke, 2010, p. 401ff). Figure 1 below visualises some of these waves. In this development, key moments were the introduction of direct elections to the European Parliament in 1979 and the 2003 regulation on Europarties.

First, in 1969, the decision to introduce direct elections to the EP pushed early formats for the coordination of work within the Parliament to deepen cooperation also outside of the Parliament. Thus, in 1974, the Socialist International replaced its Liaison 
Bureau of delegates from the six member parties of the European Communities (EC) with the Confederation of the Socialist Parties of the EC (Lightfoot, 2005, p. 29; see also Hix \& Lesse, 2002, p. 11-25). Liberal parties established the Federation of the Liberal Parties in the EC in 1976. The ambition of the Christian democrats went even further with the establishment of the EPP in 1976, but disagreements over the identity and membership of the EPP complicated the process. In 1978, this ultimately led to the establishment of the European Democrat Union, which brought together conservative parties and sister parties from outside the EC (Jansen \& Van Hecke, 2011, p. 34ff).

\section{Figure 1 | Number of Europarties, 1973-2018*}

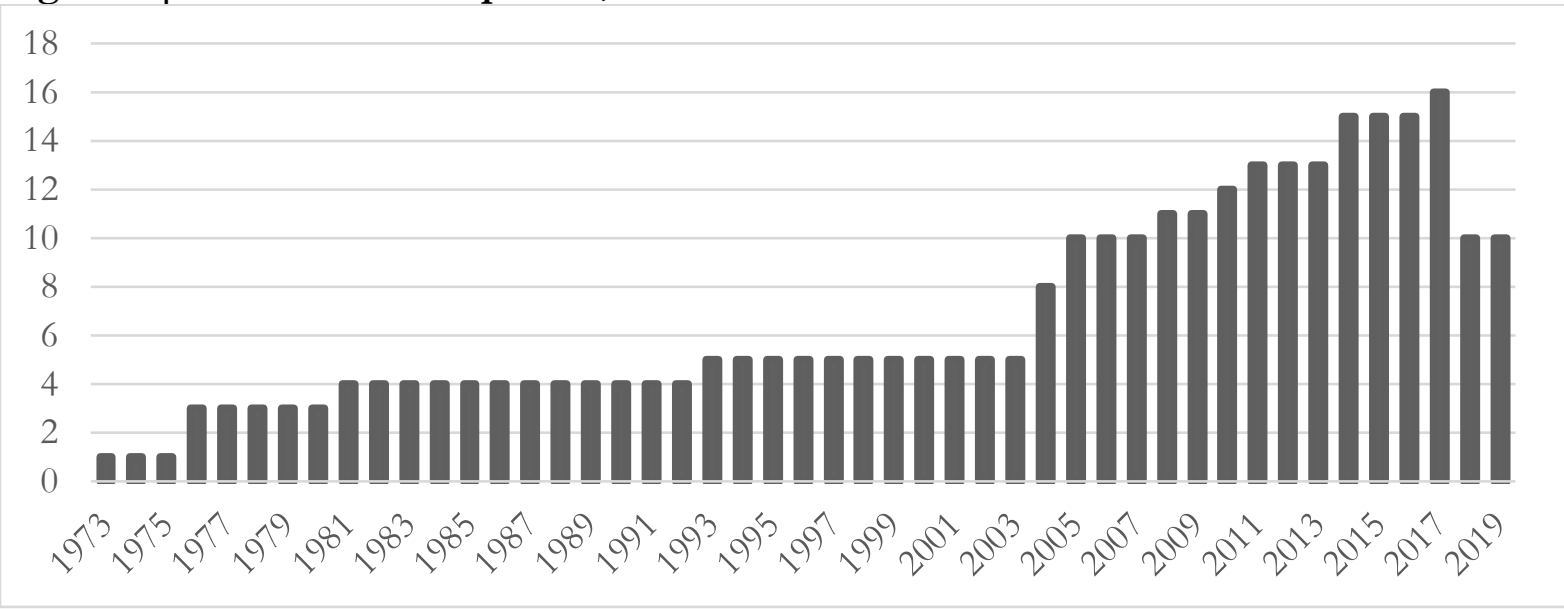

See table 3 for an overview of the creation and dissolution of Europarties. Own compilation and European Parliament (n.d.) Funding from the European Parliament to political parties at European level per party and per year, bttp:/ / wmw.europarl.europa.eu/pdf/grants/funding_amounts_parties_01-2019.pdf.

* The category 'Europarties' includes those parties that have been recognized by the EU since 2004 and that were awarded funding.

Despite the initial optimism in the 1970s, the years after the first direct elections were a "period of stagnation" (Hix, 1996, p. 316ff). Drafting of Europarty election manifestos proved to be difficult, let alone developing common election campaigns. Yet in the 1990s, a second wave in the development of the European party federations occured. This concerned not so much an increase in the number of Europarties, but rather a further development of the role and organisation of Europarties. That is, in the negotiations ahead of the Maastricht Treaty, party leaders started to meet prior to European Council meetings to discuss the highly political matters on the agenda of the Inter-Governmental Conference (p. 318ff). These meetings were subsequently institutionalised. Thereby, Europarties acquired a role as "forums for coalition building" prior to high-level intergovernmental meetings (p. 319-320; see also Ladrech, 2003, p. 116ff on the PES). The Maastricht Treaty also for the first time recognised "political parties at the European level" as "a factor for integration within the Union" (Article 138a, see also table 2).

A third wave then took place in 2004. This time, there was an increase in the number of Europarties. One may suspect that this increase was due to the substantial enlargement of the EU at the time, but parties from the 2004 and 2007 member states 
mostly joined existing Europarties (Bressanelli, 2014). Rather, a new regulation on the funding of Europarties, established in November 2003, opened the door for Europarties to receive money from the EU budget (see table 2). The regulation acted as "catalyst" for the establishment of new political parties Johansson, 2009, p. 160; see also Lightfoot, 2006 , p. 309). In the years immediately after the regulation, the number of Europarties doubled (see figure 1). Membership of these newly established parties was rather 'mixed' between parties from older and newer member states.

Table 2 | Development of Treaty articles and EC/EU regulations on Europarties

\begin{tabular}{|c|c|c|}
\hline Year & Treaty/Regulation & Importance \\
\hline 1992 & $\begin{array}{l}\text { Maastricht Treaty, } \\
\text { Article } 138 \mathrm{a}\end{array}$ & Recognises European parties \\
\hline 2001 & $\begin{array}{l}\text { Nice Treaty, Article } \\
\text { 191, Declaration } 11\end{array}$ & Provides basis for adoption of regulations and rules for funding \\
\hline 2003 & $\begin{array}{l}\text { Regulation (EC) No } \\
2004 / 2003\end{array}$ & Enables Europarties to receive funding from the EU budget \\
\hline 2007 & $\begin{array}{l}\text { Regulation (EC) No } \\
1524 / 2007\end{array}$ & $\begin{array}{l}\text { Allows for establishment of European political foundations and } \\
\text { for financing campaigns in European elections }\end{array}$ \\
\hline 2014 & $\begin{array}{l}\text { Regulation (EU, } \\
\text { Euratom) No } \\
1141 / 2014\end{array}$ & $\begin{array}{l}\text { Grants Europarties European legal status and founds the } \\
\text { Authority for Europarties and European political foundations }\end{array}$ \\
\hline 2018 & $\begin{array}{l}\text { Regulation (EU, } \\
\text { Euratom) 2018/673 }\end{array}$ & $\begin{array}{l}\text { Lowers co-financing requirement, posits that individuals cannot } \\
\text { sponsor Europarty registration, and requires member parties to } \\
\text { publish Europarty programme and logo }\end{array}$ \\
\hline
\end{tabular}

See also Johansson (2009, p. 166).

Finally, the creation of various "populist nationalist" Europarties was as a fourth and somewhat longer wave in the development of Europarties (Gómez-Reino, 2017, p. 168ff). This wave occurred in concurrence with the growing electoral success of populist nationalist parties across many EU member states. Over the years 2009-2017, seven Europarties on the populist nationalist side of the political spectrum were created that received EU funding, while three dissolved (see table 3). As from 2018, another six parties stopped receiving EU funding. The development of Europarties on this side of the political spectrum has thus clearly been fragmented (Gómez-Reino, 2017, p. 168).

\section{How Europarties organise and facilitate linkages between national political parties}

The development of the Europarties has been closely connected to the development of the political groups in the European Parliament. Indeed, the European Parliament has by far and large been the "institutional point of focus" of the Europarties (Pridham, 1986, cited in Hix, 1996, p. 318) and, up until 2004, the Europarties were also financially dependent on the political groups.

The Europarties, however, gradually institutionalised also outside the framework of the EP. For one, they have been explicitly recognised in Treaty articles, and their functioning has been established in regulations (see e.g. Johansson, 2009, p. 165ff; 
Lightfoot, 2006). Table 2 provides a summary of these developments. Most importantly, Europarties have become entitled to receive funding directly from the budget of the EU and have obtained European legal personality. This means that their organisation is no longer dependent on various national provisions (Grosek, 2018). At the same time, Europarties do by far and large rely on the financial resources of the EU budget, so that they are highly dependent on the EU and have little incentive to strengthen ties to wider society (Nielsen, 2018).

In terms of their organisation, most Europarties have a Presidency, a Congress, and a Council - although these bodies go by different names in different Europarties. The Presidency is the executive organ. It functions as the political representation of the Europarty and implements decisions taken by the Council. It is usually elected by the Congress and often includes the leader of the EP political group. The Congress convenes delegates from full member parties, as well as from affiliated members. It is often the highest organ of Europarties, as it may approve a common election programme and common top candidate(s) for European elections. The Council normally brings together the Presidency, delegates of member parties, and other important political actors, including members or delegates from the EP political group. It may, for example, decide on Europarty membership, the budget, party statutes, and on the appointment of a Secretary General - although some of these decisions may also be up to the Congress. Europarty decisions are usually made through simple or qualified majority, but Europarties cannot enforce decisions upon national parties. Finally, several Europarties additionally have "working groups" to discuss and propose ideas around particular European issues and a Secretariat or Team as a "permanent body" that is responsible for day-to-day management (Külahci, 2010, p. 1284-1285).

The presence of a permanent team facilitates informal day-to-day contacts between Europarties and national parties, and between national parties themselves. Particularly Secretary Generals and Deputy Secretary Generals often maintain a strong network of personal contacts in member parties. Other staff members can be seconded from the member parties or the EP party group, which may further facilitate the development of cross-party linkages. Several Europarties have also incorporated responsibilities for informal relations in their administrative infrastructure. This includes the maintaining of databases of member parties (e.g. at the EPP), assistants who are specifically assigned with member party relations (e.g. at the EGP), and staff responsible for advising member parties on issues such as fundraising, campaign management and party organisation (e.g. at the ALDE). Some parties, including ALDE, EGP, EPP, and PES also organise regular meetings between the campaign or social media managers of member parties.

Apart from facilitating transnational linkages between national party offices, Europarties facilitate links between party elites in government. Over the course of the 1990s, they have institutionalised the so-called 'summits' between party leaders prior to European Council meetings or important ministerial meetings. These summits are usually organised by the PES, EPP, and ALDE, because their member parties most regularly 
hold government office. The main motive of the summits is "to discuss items on the agenda, develop strategies, and - whenever possible - hammer out a common line" (Johansson, 2015, p. 6). Because the summits bring together national leaders, Commissioners and MEPs, they play an important role in mobilising political alliances across EU institutions (e.g. Hix, 1996, p. 318; Johansson, 2015, p. 10; Van Hecke, 2010, p. 406;).

Finally, the formulation of common Europarty positions on EU policies connects member parties and signals links between them. In view of European elections, most Europarties formulate some form of a common manifesto or programme. Several Europarties also ongoingly publish policy positions on particular issues, often in the form of resolutions. Crucially, the largest Europarties have elected lead candidates to run for Commission President since the 2014 elections. This was a response to a provision in the Lisbon Treaty that establishes a link between the European elections and the proposition of a candidate for Commission President by the European Council. Through this practice, several, but not all, Europarties seek to introduce an elected President who represents a majority in the European Parliament. Although the system's success in achieving its ultimate aim has been mixed, the Spitzenkandidaten do symbolise the presence of a party family and the increasing role that Europarties seek to play in interinstitutional decision making (see e.g. Christiansen, 2016; for a history of the Spitzenkandidaten procedure, see Peñalver García \& Priestley, 2015; Reiding \& Meijer, 2019; Westlake, 2016).

\section{3 | Relations between national parties and political groups in the European Parliament}

\section{Role and development of the political groups in the European Parliament}

The political groups in the European Parliament consist of national party delegations that have organised themselves by political affiliation. They are also the intra-parliamentary organisations of the Europarties. Because not all member parties of a Europarty are represented in the European Parliament, the membership of a political group is usually smaller than that of the respective Europarty. Coordination between political groups and Europarties is facilitated not only through organisational linkages, but also through joint meetings and working groups.

Nevertheless, the political groups are relatively autonomous from the Europarties (Raunio, 2018[1997]; Delwit et al., 2004, p. 12-13). Undoubtedly, this is because political groups are the "Organisational foci" of Europarties (Bardi, 1994, p. 360). On a large majority of policy issues, the groups control how MEPs vote, even though they have no formal power to enforce group discipline on the national delegations (Hix et al., 2007; Hix \& Noury, 2009; Yordanova \& Mühlböck, 2015; compare Bowler \& McElroy, 2015). Amongst other aspects, they also direct the election of the President of the EP, divide chairs of parliamentary committees and rapporteurs on legislative proposals, and allocate 
time to speak in the plenary (Delwit et al., 2004, p. 22). As such, the political groups provide the most important infrastructure for the organisation of the European Parliament's work.

It is thus not surprising that the official recognition of the political groups significantly pre-dates that of the Europarties. In 1953, the Assembly of the European Coal and Steel Community adapted its Rules of Procedure so as to officially recognise the groups that had already developed in practice. The three political groups at the time - the Christian-Democratic Group, the Socialist Group, and the Group of Liberals and Allies also acquired financial resources, which allowed them to organise independent administrative support structures and hire own staff members. The groups subsequently further structured the organisation of the EP, for instance by dividing important positions amongst each other. When in 1979 the first direct elections were held, the political groups "dominated all aspects of the parliament's work" (Hix et al., 2007, p. 23; see also Raunio, 2018[1997]).

As a result of further European integration, and of the increasing powers of the EP to control the Commission and participate in law-making, the political influence of the political groups grew substantially over the years. The largest political groups, the EPP and the S\&D, have dominated decision making. This is because the Parliament normally decides by majority and important parliamentary positions are allocated proportionally to the size of the groups. The EPP and the S\&D have held the majority of seats from the first up until the eight European Parliament, and hold about $45 \%$ of seats in the tenth Parliament (2019-2024). A coalition between these two blocks long dominated politics in the EP, but since the late 1990s, coalitions on the centre-left and centre-right have increasingly acted against each other (e.g. Kreppel \& Hix, 2003; Kreppel \& Tsebelis, 1999). The other political groups (see table 3) have usually held between $5 \%$ and $10 \%$ of seats.

The administrative infrastructure of the political groups has substantially increased over the course of the further development of the EP. In the period 1979 to 1982, for example, the number of full-time administrative posts of the political groups rose from 66 to 123. This was a response to the introduction of direct elections (Corbett, 1998, p. 90). Thereafter, the number of staff members increased more gradually as a result of further integration and the enlargement of the EU (see also Bressanelli, 2014). The staff of the political groups is organisationally separate from the assistants of MEPs and the Secretariat of the EP. Moreover, the political groups employ significantly more people than the Europarties do. For example, while both the S\&D and EPP political groups employ nearly 300 staff members, the corresponding Europarties PES and the EPP only employ nearly 40 and 50 staff members respectively. 
Table 3 | Overview of establishment of political parties at the European level ('Europarties')

\begin{tabular}{|c|c|c|c|}
\hline Europarty & $\begin{array}{l}\text { Founding } \\
\text { conference* }\end{array}$ & $\begin{array}{l}\text { Funding } \\
\text { by EU } * *\end{array}$ & EP political group* \\
\hline Party of European Socialists & $1974 / 1992 * *$ & Since 2004 & $\begin{array}{l}\text { Group of the Progressive Alliance of Socialists and } \\
\text { Democrats }(\mathrm{S} \& D)\end{array}$ \\
\hline Alliance of Liberals and Democrats for Europe Party & 1976 & Since 2004 & Renew Europe (previously ALDE) \\
\hline European People’s Party & 1976 & Since 2004 & Group of the European People's Party (EPP) \\
\hline European Greens & $1993 / 2004^{* *}$ & Since 2004 & Group of the Greens/European Free Alliance (Greens/EFA) \\
\hline European Christian Political Movement & 2002 & Since 2010 & European Conservatives and Reformists Group (ECR) \\
\hline Alliance for Europe of the Nations & 2002 & 2004-2009 & Union for Europe of the Nations \\
\hline European Democratic Party & 2004 & Since 2004 & Renew Europe (previously ALDE Group) \\
\hline European Free Alliance & 2004 & Since 2004 & Group of the Greens/European Free Alliance ((Greens/EFA) \\
\hline Party of the European Left & 2004 & Since 2004 & $\begin{array}{l}\text { Confederal Group of the European United Left - Nordic } \\
\text { Green Left (GUE-NGL) }\end{array}$ \\
\hline Europeans United for Democracy & 2005 & $2006-2017$ & $\begin{array}{l}\text { Confederal Group of the European United Left - Nordic } \\
\text { Green Left (2005-2009) Independence/Democracy }\end{array}$ \\
\hline Alliance of Independent Democrats in Europe & 2005 & $2006-2008$ & Independence/Democracy \\
\hline The Libertas Party Limited & 2008 & 2009 & No information \\
\hline Alliance of Conservatives and Reformists in Europe & 2009 & Since 2010 & European Conservatives and Reformists Group (ECR) \\
\hline Alliance of European National Movements & 2009 & 2012-2017 & Non-attached members \\
\hline European Alliance for Freedom & 2010 & $2011-2017$ & Europe of Nations and Freedom Group \\
\hline Movement for a Europe of Liberties and Democracy & 2011 & $2012-2015$ & Europe of Freedom and Democracy Group \\
\hline Alliance for Direct Democracy in Europe & 2014 & $2015-2017$ & Europe of Freedom and Direct Democracy Group \\
\hline Movement for a Europe of Nations and Freedom & 2014 & Since 2015 & Europe of Nations and Freedom Group \\
\hline Alliance for Peace and Freedom & 2015 & 2016-2017 & Non-attached members \\
\hline Coalition pour la Vie et la Famille & 2017 & 2017 & No seats \\
\hline
\end{tabular}

* Information from the websites of the Europarties, Janssen (2016), Johansson (2009, p. 161), Nordsieck (2019), and Salm (2019). 
** The parties themselves refer to the later years (1992 and 2004 respectively) as their year of their foundation. They were, however, preceded by transnational party federations launched earlier, namely the Confederation of the Socialist Parties of the EC established in 1974 (see Lightfoot, 2005) and the European Federation of Green Parties in 1993 (see Dietr, 2000).

*** Source: European Parliament (n.d.). 


\section{Contacts between EP political groups and national parliamentarians}

When discussing the transnational contacts of national parties with the EP political groups, an important distinction needs to be made between contacts of national parties with their own national party delegation in the European Parliament, and contacts with MEPs or staff from delegations of other member states. That is, national parties engage most frequently with their own national party delegation (Miklin \& Crum, 2011, p. 6). This is logical, given that MEPs are a member of national parties and are elected on the basis of national lists. There is thus an incentive to coordinate political positions and behaviour with each other, and such coordination is facilitated by relatively short lines of communication. Coordination with the national party delegation in the EP exists both at the level of the party in central office and at the level of the party in parliamentary office. It is sometimes formally organised. For example, in some national parties the leader of the national delegation in the EP is a member of the national party executive (on the organisational adaptation of national parties to the EU, see e.g. Poguntke, Aylott, Carter, Ladrech \& Luther, 2007). Most contacts are, however, informal (Miklin \& Crum, 2011, p. 6-7).

Transnational contacts between national parties and EP delegations from other member states can also both be formal and informal. On the more formal side of this spectrum are multilateral meetings on particular issues or policy areas. Several EP political groups occasionally organise these with their counterparts in national parliaments. The EPP Group, for example, organises biannual summits during which all parliamentary group chairs of affiliated parties meet. On the more informal side, political groups may maintain networks of young MPs or of spokespersons for EU affairs (e.g. EPP Group, n.d.). To maintain such contacts with MPs, the secretariats of the political groups usually employ one or more administrators in charge of relations with national parliaments.

Cross-national contacts between MPs and MEPs also occur informally. They are, for instance, facilitated by the personal networks of MPs and MEPs, or of their staff members. This may become particularly relevant when an MEP within the party group is the responsible EP rapporteur on a dossier that is salient in a particular national parliament (interview 34).

\subsection{Processes towards the institutionalisation of inter-parliamentary cooperation}

\section{Historical development of inter-parliamentary contacts}

Platforms for inter-parliamentary cooperation in the European Union developed considerably later than the Europarties and EP political groups (see table 4 and figure 2). A first inter-parliamentary meeting took place when the speakers of the national parliaments and the European Parliament gathered in Rome in 1963. It was initiated by Gaetano Martino, President of the Parliamentary Assembly at the time (IPEX, 2018), who 
had first suggested the idea to the governments of the six Member States (European Communities, 2001, p. 33). The aim of the meeting was to coordinate the activities of the European Parliament with those of the national parliaments, so that the activities of the former would find more resonance in the latter. At the time, this was believed to be important in the context of a broader concern with inciting a "European awareness" among citizens (EU Speakers Conference, 1963). Thus, the concern was mostly with developing bilateral cooperation between the EP and individual national parliaments (NPs) (Kieffer \& Millar, 1979, p. 43).

After a next meeting of the Speaker's Conference in Rome in 1975, coordination between the NPs and the EP became more institutionalised. In 1975, it was stressed that more cooperation could address "the relationship between their [national] parliaments and that of the Community" as well as "general problems of parliamentary democracy in modern times" (EU Speakers Conference, 1975, p. 31). The parliaments established the format and frequency of their future meetings and discussed the creation of a commission in the EP to deal with inter-parliamentary relations. The Speakers' Conference eventually became autonomous in 1999. The 1975 Conference also provided for the creation of the European Centre for Parliamentary Research and Documentation (ECPRD) to facilitate cooperation between parliamentary libraries, research, and data-processing services. The ECPRD can be seen as the "first attempt to achieve cooperation in this field on a multilateral basis between parliaments in Europe" (Kieffer \& Millar, 1979, p. 43; see table 5 for an overview of the administrative infrastructure for inter-parliamentary cooperation in the EU).

Subsequent developments, however, changed the nature of relations between the EP and NPs. In 1979, the first direct elections to the European Parliament put an end to the 'dual mandate' of parliamentarians (Herman \& Van Schendelen, 1979). That is, before 1979, parliamentarians had a mandate as member of both the EP and of their respective national parliament. With the introduction of direct elections, the role of MEPs mostly became defending the European interest vis-à-vis the Council of Ministers, while the role of MPs mostly became scrutinising the government representatives in the Council (Kieffer \& Millar, 1979, p. 44).

In this context, representatives from the EP and the newly established parliamentary committees for EU affairs in the national parliaments first met in 1989. The conference was a response to the feeling that NPs "were losing contact with Community policies" as a result of direct elections to the EP, but also a response to emerging debates about the so-called 'democratic deficit' in the EU (COSAC, 2014a, p. 4-5). Over the course of the early 1990s, the conference institutionalised in the Conference of Parliamentary Committees for Union Affairs (COSAC), which aims to focus on "the practical aspects of parliamentary scrutiny" of EU affairs (Rules of Procedure, 2011, p. 3). In practice, COSAC has, for example, published reports about developments in scrutiny of EU affairs in NPs and has taken up an important role in the coordination of reasoned opinions under the Early Warning System (EWS) (Hefftler \& Gattermann, 2015, p. 97). 
Table 4 Overview of institutionalised forms of inter-parliamentary cooperation in the European Union

\begin{tabular}{|c|c|c|c|c|c|}
\hline & First meeting & Frequency & Main purpose & Participants & Treaty base \\
\hline \multicolumn{6}{|c|}{ General conferences and meetings } \\
\hline $\begin{array}{l}\text { EU Speakers } \\
\text { Conference }\end{array}$ & $\begin{array}{l}1975 \text { (also } \\
1963 \& 1973)\end{array}$ & Once a year & $\begin{array}{l}\text { Coordinate inter-parliamentary } \\
\text { activities }\end{array}$ & $\begin{array}{l}\text { Speakers of the NPs and the } \\
\text { President of the EP }\end{array}$ & None \\
\hline COSAC & 1989 & Twice a year & $\begin{array}{l}\text { Facilitate exchange of information, } \\
\text { best practices and views }\end{array}$ & $\begin{array}{l}6 \mathrm{MPs} \text { of Committee for } \\
\text { Union Affairs of each NP } \\
\text { and } 6 \text { MEPs }\end{array}$ & $\begin{array}{l}\text { TFEU, Protocol 1, } \\
\text { Article } 10\end{array}$ \\
\hline European Assizes & 1990 & Single event & $\begin{array}{l}\text { Discuss future development of EU } \\
\text { integration and treaty reform }\end{array}$ & $\begin{array}{l}173 \text { participants from the } \\
\text { NPs and } 85 \text { from the EP }\end{array}$ & $\begin{array}{l}\text { Declaration } 14, \\
\text { Maastricht Treaty }\end{array}$ \\
\hline $\begin{array}{l}\text { Joint Parliamentary } \\
\text { Meetings }\end{array}$ & $\begin{array}{l}2005 \text { (last } \\
\text { meeting 2011) }\end{array}$ & $\begin{array}{l}2-3 \text { times a } \\
\text { year }\end{array}$ & $\begin{array}{l}\text { Promote dialogue on major policy } \\
\text { areas }\end{array}$ & Delegations of NPs and EP* & None \\
\hline \multicolumn{6}{|c|}{ Specialized conferences and meetings } \\
\hline $\begin{array}{l}\text { Inter-Parliamentary } \\
\text { Committee } \\
\text { Meetings }\end{array}$ & no information & $\begin{array}{l}\text { About } 10-15 \\
\text { times a year }\end{array}$ & $\begin{array}{l}\text { "Discuss concrete matters of } \\
\text { legislative proposals", "focused } \\
\text { exchanges between experts"** }\end{array}$ & $\begin{array}{l}\text { MEPs and MPs from the } \\
\text { relevant parliamentary } \\
\text { committee }\end{array}$ & None \\
\hline $\begin{array}{l}\text { Joint Committee } \\
\text { Meetings }\end{array}$ & 1994 & $\begin{array}{l}1-2 \text { times a } \\
\text { year** }\end{array}$ & $\begin{array}{l}\text { "Promote dialogue between } \\
\text { European and national } \\
\text { parliamentarians at committee } \\
\text { level"** }\end{array}$ & $\begin{array}{l}\text { MEPs and MPs from the } \\
\text { relevant parliamentary } \\
\text { committee }\end{array}$ & None \\
\hline $\begin{array}{l}\text { CFSP/CSDP } \\
\text { Conference }\end{array}$ & 2012 & Twice a year & $\begin{array}{l}\text { Exchange of information and best } \\
\text { practices in CFSP and CSDP area }\end{array}$ & $6 \mathrm{MPs}+16 \mathrm{MEPs}$ & $\begin{array}{l}\text { TFEU, Protocol 1, } \\
\text { Article } 10\end{array}$ \\
\hline SECG Conference & 2013 & Twice a year & $\begin{array}{l}\text { Discuss budgetary policies and other } \\
\text { issues covered by the TSCG }\end{array}$ & $\begin{array}{l}\text { Composition and size of } \\
\text { delegation determined by } \\
\text { each parliament }\end{array}$ & TSCG, Article 13 \\
\hline JPSG on Europol & 2017 & Twice a year & $\begin{array}{l}\text { Monitor Europol's activities, and } \\
\text { discuss its budget and organisation }\end{array}$ & $\begin{array}{l}4 \text { MPs }+16 \text { MEPs selected } \\
\text { by each parliament }\end{array}$ & $\begin{array}{l}\text { TFEU, Article } 88 \text { and } \\
\text { Regulation 2016/794, } \\
\text { Article } 51\end{array}$ \\
\hline
\end{tabular}


Figure 2 | Development of platforms for inter-parliamentary cooperation in the European Union

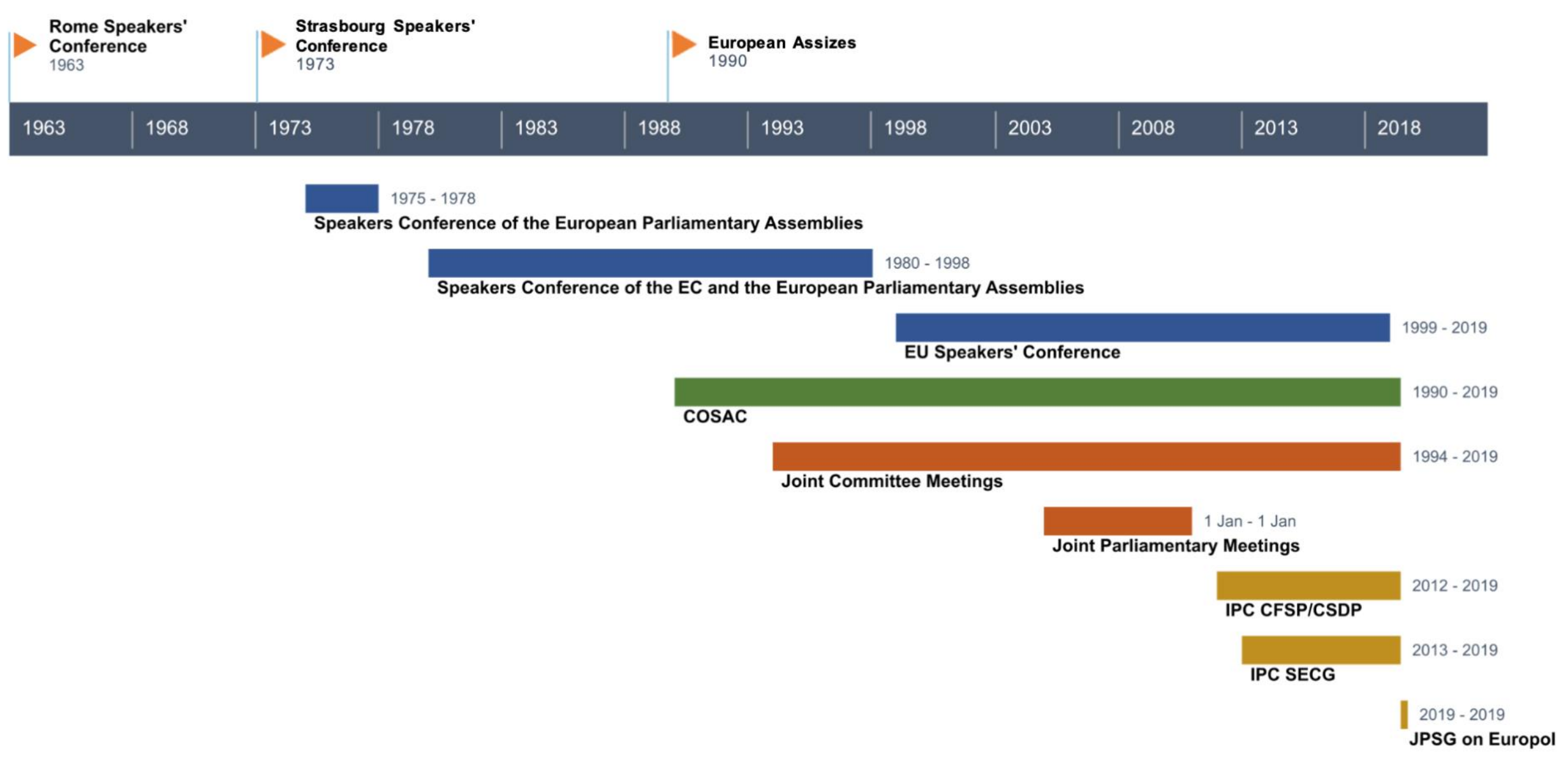

Meetings of Speakers of parliaments are shown in blue, meetings of committees for Union affair are shown in Green, meetings initiated by the European Parliament are shown in orange, and specialised inter-parliamentary meetings are shown in yellow. 
In another attempt to respond to the alleged democratic deficit, there have been repeated calls to create a general conference of parliamentarians to discuss the overall direction of European integration. Such a so-called 'Assizes', however, only took place once in Rome in 1990 in the context of the upcoming treaty negotiations in Maastricht. Although the Maastricht Treaty invited the organisation of subsequent Assizes, the format never institutionalised. Amongst other issues, there was resistance against the idea of having a new institution and experiences had been rather poor during the Rome Assizes (Shackleton, 1995, p. 172-174). In the early 2000s, the idea to create a Third Chamber of NPs encountered much opposition for similar reasons (Groen \& Christiansen, 2015).

\section{'Specialisation' of inter-parliamentary cooperation}

Institutionalisation of inter-parliamentary cooperation also advanced through other routes. Already in the early 1990s, the EP emphasized the importance of meetings and exchanges of information between MPs and MEPs along the lines of the respective parliamentary committees (see e.g. Cravinho Report, 1991; see also Neunreither, 1994). Particularly around the mid-1990s, contacts at the committee level increased, as MEPs were no longer required to seek authorisation for contacts with MPs with the Bureau of the EP (Neunreither, 2005, p. 469). In the period 2005-2011, the EP, together with the NP of the state holding the rotating Council presidency, organised regular Joint Parliamentary Meetings (JPMs) on broad European issues or policy areas.

After 2011, the interest in JPMs declined, arguably because of a trend towards 'specialisation' in the aftermath of the Lisbon Treaty that entered into force in 2009 (Cooper, 2017; Hefftler \& Gattermann, 2015, p. 97-98). That is, inter-parliamentary meetings became more specialised topic-wise, through a focus on narrower policy areas (see figure 2). These contacts have taken the form of bilateral meetings between one NP and an EP committee, but also of multilateral Joint Committee Meetings (JCMs) and Interparliamentary Committee Meetings (ICMs) (see table 4). Chairpersons of the various national parliamentary committees have also frequently visited the relevant EP committee (Hefftler \& Gattermann, 2015, p. 98-99).

Three specialised meetings institutionalised. Although these conferences do not have permanent secretariats, they can be seen as autonomous platforms. First, the Lisbon Treaty provided for the creation of the Inter-Parliamentary Conference on the CFSP/CSDP (IPC CFSP/CSDP). This conference replaced cooperation between national parliaments in the Parliamentary Assembly of the Western European Union (see Herranz-Surrallés, 2014). Second, in the aftermath of the financial crisis, the InterParliamentary Conference on Stability, Economic Coordination and Governance (IPC SECG) was established in 2013. It resulted from the Treaty on Stability, Coordination and Governance in the Economic and Monetary Union (TSCG) of 2012. The IPC SECG replaces the meetings of committee chairpersons on this topic (Rules of Procedure, 2015, art. 2.2; see also Cooper, 2016; Kreilinger, 2013). Third, a Joint Parliamentary Scrutiny Group (JPSG) on the EU agency Europol was established in 2017. Its roots can be found 
in the Lisbon Treaty, which emphasized the importance of parliamentary oversight in the area of Justice and Home Affairs.

The result of these processes towards institutionalisation of inter-parliamentary contacts may seem a labyrinth, but the various platforms have become rather streamlined with each other. As Cooper (2017) writes, the various events do not occur "in isolation but within the context of an increasingly elaborate biannual calendar of parliamentary events" (p. 15). This calendar most importantly consists of the Parliamentary Dimension, which is a series of inter-parliamentary conferences organised by the parliament of the member state holding the rotating Presidency (p. 15). Likewise, since 2013, the EP has brought together various meetings in a European Parliamentary Week in the context of the yearly European semester on the coordination of economic policies. This includes various ICMs and the IPC SECG.

Finally, inter-parliamentary cooperation has become supported by an administrative infrastructure (see table 5). COSAC has its own Secretariat, consisting of one permanent member and administrators from the national parliaments that are part of the Troika of the rotating Presidency. Other inter-parliamentary conferences and meetings are supported by the Directorate for Relations with National Parliaments of the European Parliament. NPs have also created a network of permanent representatives in the European Parliament - known as 'liaison officers' - in view of the frequent interaction between parliaments and the resulting need for expertise in parliamentary affairs (Neuhold \& Högenauer, 2016, p. 238). This network appeared in the early 2000s (p. 243). The primary role of the liaison officers is to establish contacts, facilitate the exchange of information and experiences, coordinate reasoned opinions under the EWS, and organise work visits (Mastenbroek et al., 2014, p. 19). Indeed, there are various informal visits of MPs to the EP, for instance to discuss specific policy proposals in the relevant parliamentary committee of the EP (COSAC, 2014b, p. 29).

Table 5 | Overview of administrative infrastructure for inter-parliamentary cooperation in the European Union

\begin{tabular}{|c|c|c|}
\hline Administrative infrastructure & Year & Main purpose \\
\hline $\begin{array}{l}\text { National permanent representatives in } \\
\text { Brussels }\end{array}$ & $\begin{array}{l}1991 \\
*\end{array}$ & Facilitate day-to-day exchange of information \\
\hline $\begin{array}{l}\text { European Parliament Directorate for } \\
\text { Relations with National Parliaments }\end{array}$ & $\begin{array}{l}1991 \\
* *\end{array}$ & Provide organisational support \\
\hline IPEX & 2000 & $\begin{array}{l}\text { Provide a platform for electronic exchange of } \\
\text { information }\end{array}$ \\
\hline ECPRD & 1977 & $\begin{array}{l}\text { Exchange information "to compare legislative } \\
\text { activities and parliamentary practice"*** }\end{array}$ \\
\hline \multicolumn{3}{|c|}{$\begin{array}{l}\text { * Year of first representative in Brussels, most representatives began their work in the period 2003-2008 } \\
\text { (Neubold \& Högenauer, 2016, p. 242-243). } \\
\text { ** Decision to provide funding taken in 1990: first an administrative service; from } 2003 \text { to } 2009 \text { a directorate } \\
\text { under the Directorate General for Internal Policies; since } 2009 \text { under the Directorate-General for the Presidency } \\
\text { (Neunreither, 2005, p. 482; Pegan \& Högenauer, 2016). } \\
\text { *** See bttps:// ecprd.secure.europarl.europa.eu/ecprd/public/page/about. }\end{array}$} \\
\hline
\end{tabular}




\section{How inter-parliamentary cooperation facilitates transnational party activities}

Inter-parliamentary conferences were thus designed to facilitate cooperation between national and EP delegations of parliamentarians, based on expertise. In practice, however, parliamentarians and party staff also use inter-parliamentary meetings to seek cooperation along political lines (Gattermann, 2014; Miklin, 2013, p. 37; Miklin \& Crum, 2011, p. 11;). The largest political groups in the European Parliament usually organise party family meetings on the fringe of the COSAC, the IPC SECG and the CFSP/CSDP Conference, but not at the JPSG on Europol. These meetings add a party-political dimension to interparliamentary conferences. They facilitate the development of common political lines on conference conclusions or amendments to conclusions, and also facilitate networking (interview 35). Although the meetings are frequently referred to as meetings of the political groups, they are not formally held by the EP political groups, as the latter only exist in the Parliament (interview 35). This is why I refer to them as party family meetings in this dissertation.

Party family meetings appear on the agenda of COSAC for the first time at the 32rd ordinary meeting in Amsterdam in 2004 and have been organised prior to the opening of the conference since the 34th ordinary meeting in London in 2005. The frequency with which a political group hosts the meetings depends on them being part of the EP delegation to the conference (interviews 35, 36 and 37). Thus, particularly the EPP and the S\&D, but also ALDE, have hosted family meetings at COSAC, while the Greens have less frequently done so. Family meetings by other political groups are not mentioned on the COSAC agendas, but meetings organised by GUE-NGL and ECR do appear on the agendas of the specialised IPC CFSP/CSDP and IPC SECG. For the latter conferences, also meetings organised by the ALDE, EPP, S\&D, and the Greens have been regularly mentioned on the agenda ever since 2013 .

Finally, while liaison officers play a neutral, non-partisan role that is restricted mostly to sharing information (Mastenbroek et al., 2014, p. 19; Neuhold \& Högenauer, 2016, p. 250), the officers can open the door for transnational party activities of MPs, for instance by sharing information on events in Brussels and by organising visits. This is particularly the case for the German liaison office, as it is - uniquely - both staffed by administrators from the national parliament and from the national parliamentary groups. The latter administrators "gather information about topics that are of particular interest for the parliamentary groups" and maintain "close links with the [MEPs] of the groupings to which their own parties are affiliated, MEPs' staff and other political contacts" (Deutscher Bundestag, n.d., p. 5). In practice, they coordinate the work of the parliamentary group with that of the national group in the EP, for instance through the organisation of joint meetings. Occasionally, they arrange contacts between MPs and MEPs from other member states - depending on the political issue at stake (interviews 15 and 34). 


\section{5 | Organisational structures for international cooperation of national parties themselves}

This chapter has already hinted at some of the key parliamentary actors within national parties that engage in transnational party activities: MEPs from the own member state, spokespersons on EU affairs, and MPs who attend inter-parliamentary conferences. Particularly larger parties, however, also have organisational structures of their own to organise multilateral and bilateral contacts with other national parties, and to maintain an own network with sister parties. These organisational structures are usually located within the central party office. International secretaries can, in particular, play a key role in managing day-to-day contacts with sister parties in the EU. Other important actors may be - depending on party tradition, size and resources - staff within the international department, secretary generals, and party leaders and their deputies (Hanley, 2008, p. 59).

The position of the international secretary has a long tradition in some parties, especially so in European social democratic parties. The British Labour Party, for example, appointed its first international secretary, William Gillies, already in 1920. Commonly, however, international secretaries started to play a more important role after the Second World War, when larger political parties expanded their bureaucracies and processes towards European integration started. For instance, in 1946, the newly appointed international secretary of the Labour Party expanded the party's international department, the Swedish Sveriges socialdemokratiska arbetareparti (SAP) appointed a party bureaucrat as international secretary, and the Austrian Sozialdemokratische Partei Österreichs (SPÖ) instituted a new international department (Costa, 2018a, p. 71-80).

The role of international secretaries nevertheless "varies enormously" (Hanley, 2008, p. 58). For one, it depends on the role that other high-ranking officials or politicians take on. International secretaries usually become less powerful when a party is in government office and the prime minister or foreign secretary takes on a more active role in international affairs (e.g. Costa, 2018; Hertner, 2011a; Kaiser, 2010, p. 92-93; Poguntke et al., 2007). Depending on their prior party careers, secretary generals, as well as party chairs and their deputies, have historically also been important players in international party relations. Nevertheless, within various parties, it has been the case that the same person was in charge of attending international party meetings and maintaining networks over long periods of time. At the German SPD, for example, Hans-Eberhard Dingels occupied the post of international secretary to the party board from 1961 to 1995 (see e.g. Drögemöller, 2005). Arguably, such long-term appointments facilitated the development of tight transnational networks (Salm, 2015, p. 16) and in the past of "international fraternal relations" - given that the positions were by far and large occupied by men (Costa, 2018, p. 4).

Over time, the work of many international secretaries of political parties has become more focused on EU affairs and on managing relationships with Europarties. Indeed, various parties only instituted the office of the international secretary after EU accession, such as the Austrian Green party (Luther, 2007, p. 31-32). International 
secretaries are often primarily tasked with managing relations with sister parties and with the national delegation in the EP. They also represent their parties in transnational forums, including in the Europarties and in international party organisations. Some secretaries still play a role in formulating the content of international and European policy preferences, particularly if their party is in opposition (see e.g. Hertner 2011a; Poguntke et al., 2007). Europarties themselves organise regular meetings with the international secretaries of member parties and some Europarties have instituted special organisational bodies for this, such as the PES' "coordination team".

International secretaries often have considerable autonomy to make decisions within international or European forums. This autonomy may emanate from their position close to the party leadership (e.g. Gehler, p. 2010), but also from the administrative nature of the decisions they take, such as within Europarties (e.g. Luther, 2007 , p. 43). The degree of freedom and influence of international secretaries usually depends on internal party constellations. Some parties do not have the resources to appoint a full-time, high-ranking international secretary, while other parties employ fulltime international secretaries who are a full member of the party board (see e.g. Hanley, 2008, p. 58-60; Poguntke et al., 2007).

Finally, parties with larger financial endowments may also maintain international departments. These departments are often staffed with a small number of employees in comparison to other departments (e.g. Hanley, 2008; Poguntke et al., 2007). With further European integration, several international departments have become more 'specialised' on EU affairs. They have an individual staff member or even a sub-unit charged with EU affairs (Ladrech, 2007, p. 197). The latter has, for instance, been the case within the Swedish SAP (Aylott, 2007, p. 154) and the German SPD (Hertner, 2011a, p. 197). Beyond organising relations with sister parties, these staff members or subunits may advise the party on EU affairs and participate in the formulation of national party manifestos for European elections (see e.g. Hertner, 2011a, p. 194-199; Poguntke et al., 2007).

\section{6 | Conclusion: The 'multi-level playing field' for national political parties}

In this chapter, I have presented an analytical framework to study the transnational activities of national parties in parliamentary and party office in the European Union. National parties are understood as transnational actors. That is, although national parties are national organisations by nature, they are also transnational actors in so far as they have the capacity to act across national borders and across levels of governance (Kaiser \& Starie, 2005, p. 5). Such cross-border and cross-level interactions can take place through various avenues, including most importantly the Europarties, the political groups in the European Parliament, inter-parliamentary conferences, and, finally, own party organisational structures. 
In the remainder of the chapter, I have taken stock of the development of avenues for transnational party cooperation. The chapter shows that, with further European integration, the number of platforms, conferences, meetings, and tools for party and parliamentary cooperation has grown substantially. Europarties have grown in number and in organisational capacity, even though they are still small organisations compared to many of their member parties and to their counterparts in the European Parliament. Indeed, the political groups in the EP have become more powerful in many policy areas, and the oldest and largest groups maintain sizeable administrations. The number of interparliamentary platforms has likewise increased, while conferences have become more specialised in particular policy areas. Finally, political parties themselves often have a history of maintaining own organisational capacities to engage in contacts across borders.

The emerging picture is one of a 'multi-level playing field' that national parties in the EU can engage in (on the notion of the 'multi-level parliamentary field', see Crum \& Fossum, 2009; on the notion of the 'multi-level party system', see Swenden \& Maddens, 2009). That is, parties can interact and compete with each other at different levels of governance in the EU. Such transnational activities are structured by several institutions and organisations, as well as by historically rooted rules of the 'game'. Indeed, Europarties, EP political groups, inter-parliamentary conferences, and the organisational structures for international cooperation of national parties have different functions in the context of the political system of the EU. At the same time, both their development and their actual functioning are highly interlinked. To give just a few examples, several EP political groups organise family meetings prior to inter-parliamentary conferences, the development of the Europarties has long been dependent on that of the EP political groups, and the international secretaries of national parties are key contacts in Europarty networks.

On the one hand, the nature of the multi-level playing field, with its many access points for transnational activities of political parties, may lead to optimism. Most strikingly, the various avenues have become, by and large, focused on actual decision making in the EU, rather than on discussions about the general outlook of the EU. This is visible for example in the trend towards specialisation of inter-parliamentary cooperation and in the development of Europarties as more independent organisations. On the other hand, the playing field has also been unstable and uncertain. Several platforms are new, such as some of the inter-parliamentary conferences and own party organisational structures of national parties. Some older avenues for cooperation are still subject to frequent organisational and regulative changes, which is particularly the case for the Europarties. Indeed, the mere existence of institutional platforms for cooperation does not necessarily mean that they are useful for national parties.

The complexity of the image shows that the study of the behaviour of national parties in the EU requires a focus on "the fusion of various interaction patterns, both administrative and political” (Johansson, 2004, p. 18). Thus, having analytically distinguished between avenues for cooperation, the dissertation subsequently draws these 
Chapter 1

avenues together again. Given the complexity of the multi-level playing field, what drives national parties to engage in particular types of transnational activities? Which party actors do so? When are particular avenues for cooperation most useful to them? And what domestic factors condition such choices? 


\section{Chapter 2}

\section{State of the art}

\section{Transnational party and inter-parliamentary cooperation in the European Union}

The primary aim of this chapter is to demonstrate the academic contribution this dissertation makes. I show how this research project speaks to the broader academic literature surrounding its topic, and, more importantly, how it addresses some of the lacuna in existing research. To do so, I review previous literature that has touched upon the subject of transnational party cooperation and identify its strengths and shortcomings. My discussion emphasizes those studies that have particular relevance for the topic of the dissertation. In chapter 3, I take up some of the specific findings of this literature as building blocks for my theoretically informed expectations. Providing these building blocks is thus the secondary aim of this chapter.

I put the spotlight on two bodies of literature, namely 1) research on national parliaments and EU affairs and the adjacent literature on inter-parliamentary cooperation, and 2) research on national parties and European integration and the adjacent literature on Europarties. It is important to consider both these bodies of literature, given the focus of the dissertation on the party in parliament and the party in central office. That is, to understand what drives transnational activities by actors of the party in parliament, one needs to understand how parliaments deal with EU affairs. And to understand what drives transnational activities by actors of the party in central office, one needs to understand how parties have been affected by EU integration. Although the two bodies of literature have developed disjointly from each other, they show similarities in the way they have advanced.

The main argument of this chapter is that existing literature has failed to systemically consider the informal side of transnational party activities, and the constraints and opportunities for transnational party activities that arise from domestic politics. 
Instead, by and large, scholars focus on the formal structures of cooperation, and on the functions of interaction between parliamentary and party actors at the European level. To show this, I first discuss the literature on national parliaments and inter-parliamentary cooperation; from the early, normative debates to the increasing focus on institutions and, eventually, on dynamics of parliamentary scrutiny and cooperation. I then discuss the literature on political parties and EU affairs and transnational party cooperation; reviewing the debate on the impact of European integration on the organisations of national parties and on the maturing of Europarties, as well as the few - mainly historical - contributions on actual transnational party activities. Throughout, the chapter returns to the four avenues for transnational party activities identified in chapter 1.

\section{1 | Early debates: What role should parliaments play in the European Union?}

It is not until the emerging debates about the so-called 'democratic deficit' of the 1990s that the role of parliaments in the EU really attracts academic attention (see table 6 for an overview of the bodies of literature on national parliaments 3 and inter-parliamentary cooperation4). In early debates, two questions are of particular interest, namely about the position of national parliaments vis-à-vis national governments in EU affairs, and about the position of national parliaments vis-à-vis the European Parliament.

At the time, academic literature paid considerably more attention to the former question than to the latter question. Scholars had previously signalled a persisting decline of parliamentary influence on legislation that resulted from the rise of larger and more powerful governments (see Flinders \& Kelso, 2011, p. 254-260). But in the late 1990s, some scholars develop the argument that European integration accelerates that process, as integration shifts extensive decision-making powers from the national to the European level (Raunio \& Hix, 2000, p. 147-151; see also Judge, 1995; Norton, 1996). Crucially, early studies on the role of national parliaments in the EU find that national governments enjoyed considerable freedom to promote their own preferences during Council and European Council negotiations (e.g. Judge, 1995; Laursen \& Pappas, 1995; Norton, 1996; Smith, 1996).

As the key cause for this, scholars identify an informational disadvantage of parliaments vis-à-vis governments in EU affairs (Norton, 1996, p. 6-7; Raunio, 1999a, p. 180-181). That is, because national parliaments do not have a seat at the table during Council negotiations, they do not exactly know what position the own minister adopts, what the content of the negotiations is, and what the positions of other EU member

3 See Goetz and Meyer-Sahling (2008), Raunio (2009), Winzen (2010), Rozenberg and Hefftler (2015) and Strelkov (2016) for more extensive reviews of the literature on national parliaments and the European Union.

4 See Hefftler and Gattermann (2015) for a more extensive review on inter-parliamentary cooperation in the EU. 
states are (see Héritier, 2003). Moreover, EU dossiers are often highly complex, and national parliaments may not have the necessary expertise to follow up on such technical dossiers (Neuhold \& De Ruiter, 2013; Raunio \& Hix, 2000, p. 162). The early literature stresses that the extended use of Qualified Majority Voting (QMV) for decision making in the Council made matters worse: even if national parliaments manage to control the position of the government, the government can be outvoted in the Council (Bergman, 1997, p. 375; Katz, 1999, p. 23; Norton, 1996, p. 6-7).

The idea that parliaments have lost out in the European integration process is known as the 'de-parliamentarization thesis'. First empirical studies of the 1990s look for signs of institutional adaptation to the EU of national parliaments. Such signs, for example, include the creation of specialised committees on EU affairs and formal parliamentary rights to receive information from the government (e.g. Laursen \& Pappas, 1995; Norton, 1996; Smith, 1996). Conclusions are bleak, however. National parliaments were not only institutionally and procedurally ill-equipped to instruct and scrutinise the government, but also unwilling to take up an important role in EU affairs. Amongst other reasons, this was due to a strong commitment to supranational integration, and to mistrust between MPs and MEPs (Norton, 1996, p. 189-190).

Indeed, early work on inter-parliamentary relations discusses how growing powers of the European Parliament lead to conflicts with national parliaments (Burban, 1972; Herman \& Van Schendelen, 1979; Pöhle, 1987; Scoffoni, 1992; Shackleton, 1995). On the one hand, scholars observe this conflict in practice. Westlake (1995, p. 69-71), for example, discusses rivalry between the national parliaments and the EP. On the other hand, scholars also engage in a normative discussion. That is, the growth of the EP's powers can lead to "potentially overlapping European and national parliamentary competences" (p. 59). In this respect, most early scholars, especially in the 1990s, argue in favour of a clear separation of roles (e.g. Neunreither, 1994; Westlake, 1995). As Neunreither (1994) puts it, "national parliaments [should] not give way to the temptations to get involved directly in the EU institutional system" (p. 313). Thus, the European Parliament should control the European Commission, while the national parliaments should control the Council. It is not surprising, then, that first studies on interparliamentary cooperation view cooperation as a potential way to enhance the different, but complementary roles of national parliaments and the EP (e.g. Neunreither, 1994, p. 309-311; Westlake, 1995, p. 71).

\section{2 | Early 2000s: Studies on institutional (dis)functioning of parliamentary scrutiny and inter-parliamentary cooperation}

The early 2000s see an increasing emphasis on the importance of national parliaments in the European Union, particularly in view of the momentum of the Convention on the Future of Europe that took place from 2002 to 2003 (Groen \& Christiansen, 2015; see also Rozenberg \& Hefftler, 2015, p. 6-15). In academia, a new wave of studies on national 
parliaments emphasizes a more active response of parliaments to European integration (Strelkov, 2015, p. 17). This literature particularly focuses on the institutional functioning of parliamentary scrutiny. Also the literature on inter-parliamentary cooperation shifts attention to the functioning of institutional forums for cooperation, especially in view of the further institutionalisation of cooperation at the time.

\section{Through what instruments do parliaments exercise control over governments in EU affairs?}

A key topic in the debate on national parliaments and EU affairs is the question of parliamentary strength vis-à-vis the national government. Various scholars seek to theorise on the relation between parliament and government, and to develop indicators for parliamentary strength (e.g. Auel \& Benz, 2005; Bergman, 2000; Saalfeld, 2005). While such indicators differ, the literature generally highlights three important institutional abilities of national parliaments in EU affairs (Winzen, 2012; see also Auel, 2007, p. 489490; Raunio, 2005).

First, there is widespread agreement that access to information about EU affairs and Council negotiations is key to successful parliamentary control (e.g. Benz, 2004; Auel \& Benz, 2005; Miller \& Ware, 1996). Some authors also emphasize the importance of the timing and scope of information (Raunio, 2005, p. 321-322; see also Maurer \& Wessels, 2001).

Second, many scholars stress that the ability to process information is important. That is, national parliaments face such a complex body of information about EU affairs that they may struggle to filter out what is relevant (Hegeland \& Neuhold, 2002; Miller \& Ware, 1995). In this context, scholars generally emphasize the importance of the parliamentary committees for European Affairs (EACs) in coordinating the scrutiny of EU affairs, and in monitoring government representatives in the Council (Raunio, 2005, p. 321; see also O’Brennan \& Raunio, 2007; Saalfeld, 2005). There are, however, also large differences between the roles of EACs across member states (e.g. Bergman, 1997; Hefftler, Neuhold, Rozenberg \& Smith, 2015; Maurer \& Wessels, 2001; Norton, 1996; Winzen, 2012). Some scholars emphasize the importance of sectoral committees, as these committees have more expertise on highly specialized EU dossiers (Gattermann, Högenauer \& Huff, 2016; Raunio, 2005). Finally, a few scholars study the role of administrative staff in providing technical support and in pre-selecting information (e.g. Högenauer, Neuhold \& Christiansen, 2016; Högenauer \& Neuhold, 2015).

Third, literature points to the importance of parliamentary mandates or opinions about the position that a minister can adopt in Council negotiations (e.g. Pahre, 1997; Raunio, 2005; Winzen, 2012). In a few member states, these mandates are legally binding, but they are more often informal or politically binding (Mastenbroek et al., 2014, p. 15). There is also variation between parliaments in the timing of mandates. While some parliaments give instructions prior to meetings, questioning afterwards is more important in others (Raunio, 2005, p. 322-323). 
Another key debate is about what explains differences in the institutional set-up of parliamentary scrutiny of EU affairs. In this regard, institutionalist approaches and concepts from the study of comparative politics have been dominant (Goetz \& MeyerSahling, 2008, p. 10). These explanations, for example, point at prior institutional constellations and slow institutional adaptation (Benz, 2004; Dimitrakopoulos, 2001); perceptions of European integration (Norton, 1996) and national political culture (Bergman, 1997); and the strategic interests of MPs and electoral salience of EU affairs (Raunio, 2005; Saalfeld, 2005; compare Karlas, 2011).

\section{How do platforms for inter-parliamentary cooperation function?}

The literature on inter-parliamentary cooperation of the early 2000s is closely linked to the concerns of the literature on national parliaments about the scrutiny of governments in EU affairs. Most scholars focus on the institutional functioning of cooperation with a view to reinforcing the parliamentary strength of national parliaments vis-à-vis governments. Particularly COSAC receives much attention (e.g. Bengtson, 2007; Costa \& Latek, 2001; Larhant, 2005; Tordoff, 2000; see also Mitsilegas, 2007 on the area of justice and home affairs). Although these studies are highly descriptive (Raunio, 2009, p. 324), they do provide some first insights into the potential benefit of cooperation for national parliaments. Bengtson (2007), for example, argues that the main function of COSAC is to facilitate the exchange of information and best practices for parliamentary scrutiny. Larhant (2005) similarly finds that the exchange of information has been one of the main functions of cooperation. Authors also highlight coordination of the scrutiny of specific policy dossiers and of common positions as a potential function of cooperation, but generally suggest that such coordination is not effective (e.g. Bengtson, 2007; Larhant, 2005; Mitsilegas, 2007).

Indeed, first studies on the functioning of cooperation in particular interparliamentary forums first and foremost illustrate the limits of cooperation. Tordoff (2000), for example, finds that there are problems with COSAC both in terms of its organisation and in the conduct of its meetings. He critiques the "high level of generality" of debates that results from great diversity in national parliamentary practices and political preferences (p. 7). Costa and Latek (2001) likewise argue that there are "limits" particularly to COSAC, as the most important forum at the time. They point to the nonbinding character of contributions and the ambiguous position of the European Parliament as an actor in COSAC. Given the structural problems of "heterogeneity of national parliaments" and "constitutional friction between MEPs and MPs" (Kiiver 2006, p. 125), Raunio (2009) concludes that inter-parliamentary cooperation is "bound to remain of limited importance" (p. 324). 


\section{3 | After Lisbon: Studies on the dynamics of parliamentary scrutiny and inter-parliamentary cooperation}

After 2007, the conclusion of the Lisbon Treaty gives research on national parliaments and inter-parliamentary cooperation a new boost (see Gattermann \& Hefftler, 2015a; Rozenberg \& Hefftler, 2015, p. 13-15). New studies on national parliaments want to go "beyond institutional capacity", as formal parliamentary strength does not always predict actual parliamentary involvement (Gattermann \& Hefftler, 2015b). Also the literature on inter-parliamentary cooperation turns towards the study of practices in certain policy areas. An important theme in the new wave of studies on national parliaments are motivations to engage in parliamentary scrutiny, but this theme only receives limited attention in the literature on inter-parliamentary cooperation.

\section{The Early Warning System for the principle of subsidiarity and the notion of the multi-level parliamentary field}

In the post-Lisbon literature on national parliaments and inter-parliamentary cooperation, two new strands of research stand out, namely research on the Early Warning System for the principle of subsidiarity (EWS) and research on the emergence of inter-parliamentary forums in specific policy areas.

First, Protocol 2 of the Lisbon Treaty added the instrument of the EWS to the toolbox of national parliaments. In brief, the EWS grants a national parliament the possibility to send a so-called 'reasoned opinion' to the European Commission if it believes that a proposed piece of legislation breaches the principle of subsidiarity. If the number of opinions reaches the threshold of one third of the votes allocated to all national parliaments in the EU, a 'yellow card' is issued. The Commission must then review its proposal. Research on the actual working of the EWS within national parliaments shows that the instrument leads to an increased amount of information that parliaments have to digest (Högenauer \& Neuhold, 2015, p. 388). Engaging with the subsidiarity checks may, however, give rise to more attention to EU issues overall (Miklin, 2017). Moreover, for the system to work the EWS requires much exchange of information between national parliaments, which creates a need for new interparliamentary platforms (Kaczyński, 2011; see also Granat, 2018).

Indeed, literature on inter-parliamentary cooperation emphasizes that cooperation is crucial for the effective functioning of the EWS. This is the result of the nature of the EWS as a collective tool for parliaments (Knutelská, 2013, p. 47). In his analysis of the first yellow card on the Monti II regulation, Cooper (2015) shows that coordination is key to reach the threshold of one third of the votes. He finds that one national parliament can take on the role of "initiator" for a yellow card, that COSAC can provide an informal venue for contact between MPs to lobby for a yellow card, and that the liaison officers play a crucial role in coordination and information exchange (p. 1412). Neuhold and Högenauer (2016) more strongly emphasize the importance of contacts at the administrative level. They find that the national parliamentary representatives in Brussels 
make up a routinised information network that facilitates effective domestic scrutiny and use of the yellow card procedure (p. 16).

Second, literature on Inter-Parliamentary Cooperation (IPC) - which authors by this time start to refer to as a distinct field of studies - takes up the study of practices of cooperation in particular policy fields. On the one hand, this reflects actual developments in the field, as a number of specialised platforms for inter-parliamentary cooperation emerge after 2012. On the other hand, this results from conceptual developments in the literature. That is, Crum and Fossum (2009) introduce the notion of the "multi-level parliamentary field". They argue that the European Parliament is a "direct" channel of representation at the supranational level, while the national parliaments are an "indirect" channel of representation at the national level (p. 251-254). Parliamentary representation in the EU thus occurs at different levels, so that the role of one parliament can only be understood in relation to others (p. 269). Because the division of powers between the national and European level differs by policy area, the notion of the multi-level parliamentary field directs attention to cooperation in particular areas (e.g. Crum \& Fossum 2013).5

In this context, studies on inter-parliamentary cooperation in the field of the CFSP have been particularly plentiful (but see Ruiz de Garibay, 2013 on Justice and Home Affairs and Lupo \& Griglio, 2018 on Stability, Economic Coordination and Governance). Several scholars see cooperation in this field as promising for better democratic processes in the EU. That is, the CFSP is an intergovernmental area in which the EP has few formal powers and in which also many national parliaments traditionally have weak scrutiny powers (e.g. Raube, Müftüler-Baç \& Wouters, 2019; Herranz-Surrallés, 2014; Peters, Wagner \& Deitelhoff, 2010). Herranz-Surrallés (2014; compare Herranz-Surrallés, 2019), however, shows that inter-parliamentary cooperation within the IPC CFSP/CSDP may also give rise to a multi-level parliamentary "battlefield". She argues that interparliamentary relations can become confrontational when there is a discrepancy between the formal authority and the actual resources, expertise, and network of the EU and of the national parliaments.

\section{Opening the 'black box' of national parliaments: Motivations to engage in parliamentary scrutiny}

After Lisbon, scholars on national parliaments also increasingly study motivations of parliamentary parties and MPs to engage in parliamentary scrutiny of EU affairs. Crucially, these studies open the 'black box' of parliaments, and point to the importance of dynamics between government and opposition parties. That is, to explain why some parliaments or parliamentary actors make more use of formal instruments than others, several studies argue that the motivation to engage in EU scrutiny is linked to the lines of conflict within parliaments (see Winzen, 2010, p. 5-6). 
Scholars most importantly argue that government parties have less incentive than opposition parties to use scrutiny instruments in EU affairs, and that opposition and government parties employ different strategies to different ends (see Auel, 2007, p. 491492). This is because government parties hold a majority of seats in the national parliament in most European parliamentary systems. As party discipline is generally strong, the government can count on its parliamentary majority to support its policies and positions. Hence, Auel and Benz (2005), for example, explore how coalition and opposition parties deal with a "dilemma" between scrutinising the government in EU affairs and, for opposition parties, obstructing such negotiations or, for coalition parties, going against the own government (see also Maurer \& Wessels, 2001, p. 464).

Such interactions between and amongst government and opposition parties can play out differently in different parliaments. This depends on the formal power of opposition parties to scrutinise the government in EU affairs (Holzacker, 2005) and, in particular, on the usual modes of interaction between parties within a parliament (Holzacker, 2002; Damgaard \& Jensen, 2005; Pollak \& Slominski 2003; Strelkov, 2015). A detailed case study of the Dutch parliament suggests that usual government/opposition relations also explain the degree to which parties are involved in scrutiny during the phase of transposition of EU law into national law (Mastenbroek, Spendzharova \& Versluis, 2014).

Only very few studies, however, more systematically explore differences in the degree to which government and opposition parties engage in scrutiny activities. Most importantly, the large study of Finke and Herbel (2015) covers eight member states over a period of thirteen years. They find that opposition parties especially engage in parliamentary scrutiny when they are against the position of the government and when the government only controls a small majority of seats in parliament. As such, "opposition parties carefully consider their chances of successfully influencing the government's policy position" before they actually engage in scrutiny (p. 508). Other authors emphasize the importance of considering different types of scrutiny activities of government and opposition parties (Sprungk, 2010; Hefftler, 2018). In particular, Hefftler (2018) shows that government/opposition dynamics are strongly visible in parliamentary debates about EU affairs, even when they are less clear from how often parties use formal scrutiny instruments.

Existing studies provide two other explanations for the level of engagement in actual parliamentary scrutiny. First, some scholars highlight the importance of the availability of expertise. Sprungk (2010), for example, finds that the involvement of specialized sectoral committees is crucial, because parliamentarians in these committees act as "policy experts" and can formulate more precise instructions to the government (p. 16; see also Neuhold \& De Ruiter, 2010).

Second, some literature argues that the political salience of an EU dossier is important. That is, from a rational-choice perspective, MPs who seek re-election are more motivated to be active on dossiers that are politically important or attract much media 
attention (e.g. Huff 2015; Saalfeld 2005). Other scholars connect salience to levels of Euroscepticism or support for EU integration (e.g. Auel, Rozenberg \& Tacea, 2015; Raunio, 2005). Although this argument may explain variation in the strength of institutional parliamentary procedures (e.g. Bergman, 1997; Raunio, 2005; Saalfeld, 2005), empirical evidence about the importance of Eurosceptic attitudes for actual levels of national parliamentary scrutiny is inconclusive (compare Auel \& Höing, 2015; Huff, 2015).

\section{Why parliamentarians (do not) engage in inter-parliamentary cooperation}

While the literature on national parliaments thus emphasizes differences between government and opposition parties for patterns of domestic scrutiny of EU affairs, most literature on inter-parliamentary cooperation pays little attention to the role of political parties as such. Indeed, there are only very few studies that provide insights into the motivation of parliamentary actors to engage in inter-parliamentary cooperation. These studies mostly provide explanations for variation in the level of involvement of national parliaments and individual MPs in inter-parliamentary cooperation (e.g. Gattermann, 2014; Gattermann \& Heffler, 2015b; Hefftler, 2015; Miklin, 2013; Malang, 2019; Wagner, 2013). There are also some insights from surveys (e.g. Miklin \& Crum, 2011) and casestudy descriptions (e.g. Crum \& Fossum, 2013a).

Importantly, the few studies that do consider parties' incentives to engage in interparliamentary cooperation first suggest that cooperation along the lines of national political parties is more highly valued than cooperation within formal inter-parliamentary institutions (Hefftler, 2015; Miklin, 2013). They also find that most cooperation takes place between national parties and their own national counterparts in the EP (Miklin \& Crum, 2011; Miklin 2013). Based on quantitative data about attendance of MEPs at Joint Parliamentary Meetings, Gattermann (2014), for example, argues that parliamentarians seek cooperation with ideologically similar parties even during inter-parliamentary meetings. In short, then, the majority of cooperation seems to take place between MPs from ideologically similar parties (Gattermann, 2014; Hefftler, 2015; Miklin, 2013; Miklin \& Crum, 2011).

Second, studies suggest that the majority/opposition dynamic may also matter in inter-parliamentary cooperation, given that opposition parties have a higher incentive to use cooperation for information and coordination. In a case study on the Austrian political parties, Miklin (2013, p. 26-27) finds that MPs from opposition parties are more prone to engage in cooperation, because they may not receive information from the government as easily as governing parties. In a case study on the German Parliament, Auel and Benz (2005) likewise find that opposition parties use networking with MPs from Member States where the respective "sister party is in government [...] to compensate for the information head-start of the government" (p. 387). Evidence is mixed, however, as Malang (2019, p. 17 and 19) does not find that MPs from opposition parties make more use of information acquired at inter-parliamentary platforms. 
Table 6 Overview of the academic debate on national parliaments and inter-parliamentary cooperation in the European Union

\begin{tabular}{|c|c|c|c|}
\hline Origin & Main focus & Main arguments and debates on NPs* & Main arguments and debates on IPC \\
\hline $\begin{array}{l}1970 \mathrm{~s} \\
/ \\
1990 \mathrm{~s}\end{array}$ & $\begin{array}{l}\text { De- } \\
\text { parliamentarisation } \\
\text { thesis, and relation } \\
\text { NPs and EP }\end{array}$ & $\begin{array}{l}\text { Asks if NPs play any relevant role in the EU } \\
\text { - Focus: development of new institutional } \\
\text { parliamentary tools to engage in EU affairs } \\
\text { - Debate: relevant role of NPs in the EU in the context } \\
\text { of the 'democratic deficit' } \\
\text { - Argument: NPs have lost out of integration } \\
\text { - Relevant authors: Bergman, 1997; Judge, 1995; Katz, } \\
\text { 1999; Laursen \& Pappas, 1995, Norton, 1996; Raunio } \\
\text { \& Hix, 2000; Smith, } 1996\end{array}$ & $\begin{array}{l}\text { Asks what cooperation should look like } \\
\text { - Focus: development of relations between NPs and } \\
\text { EP } \\
\text { - Debate: appropriate roles of the NPs and EP } \\
\text { - Argument: cooperation has added value in the } \\
\text { context of separate roles of the NPs and EP } \\
\text { - Relevant authors: Herman \& Van Schendelen, 1979; } \\
\text { Neunreither, 1994; Scoffoni, 1992; Shackleton, 1995; } \\
\text { Westlake, } 1995\end{array}$ \\
\hline $2000 \mathrm{~s}$ & $\begin{array}{l}\text { Institutional } \\
\text { adaptation of NPs } \\
\text { and functioning of } \\
\text { forums for } \\
\text { cooperation }\end{array}$ & $\begin{array}{l}\text { Critiques perception of NPs as 'losers' of integration } \\
\text { - Focus: 'fighting back' of NPs and strength of } \\
\text { institutional power vis-à-vis the government } \\
\text { - Debate: indicators of parliamentary strength and } \\
\text { explanations for variation in degree of strength } \\
\text { - Argument: NPs have also 'fought back' } \\
\text { - Relevant authors: Auel \& Benz, 2005; Bergman, 2000; } \\
\text { Gattermann et al., 2016; Hefftler et al., 2015; Karlas, } \\
\text { 2011; Kiiver, 2006; Maurer \& Wessels, 2001; } \\
\text { O'Brennan \& Raunio, 2007; Saalfeld, 2005; Tans et } \\
\text { al., 2007; Winzen, 2012 }\end{array}$ & $\begin{array}{l}\text { Asks how cooperation actually functions } \\
\text { - Focus: experiences with cooperation in existing } \\
\text { forums } \\
\text { - Debate: functions of and difficulties with institutional } \\
\text { inter-parliamentary cooperation } \\
\text { - Argument: inter-parliamentary cooperation may fulfil } \\
\text { important functions, but is also an unfulfilled promise } \\
\text { - Relevant authors: Bengtson, 2007; Costa \& Latek, } \\
\text { 2001; Mitsilegas, 2007; Larhant, 2005; Neunreither } \\
\text { 2005; Tordoff, } 2000\end{array}$ \\
\hline
\end{tabular}


Table 6 (continued)

\begin{tabular}{|c|c|c|c|}
\hline Origin & Main focus & Main arguments and debates on NPs* & Main arguments and debates on IPC \\
\hline $\begin{array}{l}\text { After } \\
\text { Lisbon } \\
\text { Treaty } \\
(2007)\end{array}$ & $\begin{array}{l}\text { Parliamentary } \\
\text { practices and } \\
\text { specialization of } \\
\text { inter-parliamentary } \\
\text { cooperation }\end{array}$ & $\begin{array}{l}\text { Critiques focus on institutional factors as indicators of } \\
\text { parliamentary involvement in EU affairs } \\
\text { - Focus: actual parliamentary practices and involvement } \\
\text { of NPs in EU affairs } \\
\text { - Debate: what explains the use of institutional } \\
\text { parliamentary tools and level of scrutiny } \\
\text { - Argument: institutional strength alone cannot explain } \\
\text { use of parliamentary tools in EU affairs } \\
\text { - Relevant authors: Auel et al., 2015; Finke \& Herbel, } \\
\text { 2015; Gattermann \& Hefftler, 2015b; Holzhacker, } \\
\text { 2005; Huff, 2015; Miklin, 2017; Neuhold \& De } \\
\text { Ruiter, 2010; Sprungk, 2010; Strelkov, 2015 }\end{array}$ & $\begin{array}{l}\text { Moves towards theoretically informed analyses of } \\
\text { (variation in) parliamentary cooperation } \\
\text { - Focus: actual practices of cooperation in the context } \\
\text { of specific procedures or policy fields } \\
\text { - Debates: structure of cooperation in policy fields and } \\
\text { explanations for variation in level of engagement } \\
\text { - Argument: inter-parliamentary cooperation has } \\
\text { become more important } \\
\text { - Relevant authors: Crum \& Fossum, 2009; 2013; } \\
\text { Gattermann \& Heffler, 2015a; Hefftler, 2015; } \\
\text { Herranz-Surrallés, 2019; Malang, 2019; Miklin, 2013; } \\
\text { Lupo \& Fasone, 2016; Raube et al., 2019 }\end{array}$ \\
\hline $\begin{array}{l}\text { Since } \\
2014\end{array}$ & $\begin{array}{l}\text { Communicative } \\
\text { turn** }\end{array}$ & $\begin{array}{l}\text { Critiques focus on scrutiny and control function of NPs } \\
\text { in the EU } \\
\text { - Focus: link between NPs and citizens through study } \\
\text { of parliamentary debates and communication } \\
\text { - Debate: functions that NPs should fulfil } \\
\text { - Argument: there is (limited) potential in parliamentary } \\
\text { debates about the EU to increase democratic } \\
\text { accountability } \\
\text { - Relevant authors: Auel \& Raunio, 2014; Closa \& } \\
\text { Maatsch, 2014; De Wilde, 2011; Karlsson \& Persson, } \\
\text { 2018; Kröger \& Bellamy, 2016; Rauh, 2015; Wendler, } \\
\text { 2016; Winzen, De Ruiter \& Rocabert, 2018; Wonka, } \\
\text { 2016 }\end{array}$ & $\begin{array}{l}\text { Critiques focus on scrutiny and control function of NPs } \\
\text { in the EU } \\
\text { - Focus: representative function of inter-parliamentary } \\
\text { cooperation and its link to citizens } \\
\text { - Very little empirical research: Fasone (2012) finds that } \\
\text { communicative function is not fulfilled }\end{array}$ \\
\hline
\end{tabular}


At the same time, opposition parties usually cannot rely on the government to promote their policy interests in European negotiations on legislation, as governments can ignore their demands (Miklin, 2013, p. 27). Opposition MPs may thus try to influence EU decision making directly at the European level by seeking contacts and engaging in coordination with sister parties (Auel \& Benz, 2005, p. 387; see also Gattermann, 2014). Finally, Miklin (2013, p. 27-28) proposes that cooperation along party lines may also be easier and more flexible than institutional cooperation, because interests are more similar and party families have long-standing networks in Europarties and EP political groups.

\subsection{Lacuna in the literature on national parliaments and inter- parliamentary cooperation}

Overall, the literature on national parliaments and inter-parliamentary cooperation has been state-focused (see Salm, 2016, p. 6 for a similar critique). That is, by far and large, studies focus on the scrutiny and control function of parliaments in EU affairs vis-à-vis the government (on this critique, see Auel, 2007; Raunio, 2011; Auel \& Raunio, 2014). Literature on national parliaments has long focused on the formal instruments that parliaments have to control the government. Even the studies from the third wave after the Lisbon Treaty (see table 6), which look at actual practices of scrutiny in parliaments, have focused on the use of formal instruments to control government actors. Literature on inter-parliamentary cooperation has similarly studied the function of cooperation in view of scrutiny and control of the government, and of the democratic system of the EU at large (e.g. Crum \& Fossum, 2009).

As a result, there is too little attention to the informal dimension of transnational cooperation by individual parliamentary parties, as well as to functions of cooperation other than those of information and coordination to circumvent dependence on the national government. Studies that address the motivation of particular political parties and MPs to engage in inter-parliamentary cooperation are more promising in this regard. Yet the trend in the literature on national parliaments towards studying the incentives of parties and MPs to engage in EU affairs, has not continued into the literature on interparliamentary cooperation. The studies that do consider incentives mostly address motivation on a side-note, being primarily interested in the overall functioning of interparliamentary platforms (e.g. Crum \& Fossum, 2013a). Gattermann (2014) changes the level of analysis to parliamentary parties and individual MPs, but she looks only at attendance rates of Inter-Parliamentary Meetings. Malang (2019) and Hefftler (2015) combine the study of attendance rates with qualitative interviews with MPs, but likewise most importantly address the question of attendance of formal conferences.

Literature in the field of IPC that studies informal cooperation between parties or through avenues other than formal inter-parliamentary conferences is rare. Hefftler (2015) considers the liaison officers in Brussels and informal contacts to EP political groups. Miklin (2013) additionally examines the Europarties and direct contacts to sister parties. 
They both, however, study overall practices of parliamentary parties and frequency of interaction, which provides little insight into the question of when certain parties seek transnational cooperation and how that informs their work in parliament. Indeed, these questions require a move away from the focus on overarching policy areas of cooperation, and a move towards the study of substantive policy dossiers (see Fasone, 2012, p. 57). They also require a closer look at the ties between parties of the same party family beyond the party in parliament. This brings into focus the literature on the Europeanisation of national parties and Europarties.

\section{5 | After the 1979 direct elections: Studies on the emergence and development of Europarties}

Interest in the emergence and development of parties at the European level originates from the first direct elections to the European Parliament of 1979 (Deschouwer, 2000, p. 21). At the time, scholars discussed how the introduction of direct elections should be an impetus to the development of Europarties (e.g Pridham \& Pridham, 1979; 1981). Central to this literature, and also to subsequent literature, is a neo-functional concern with further European integration as a stimulus for the development of Europarties (Haas, 1958; see e.g. Johansson, 1997; Ladrech, 1993).

To start with, early literature particularly recognises that the development of Europarties can only be understood by considering both the importance of external developments in the process of European integration and of internal developments in the emerging party federations (Day, 2014, p. 8; see e.g. Johansson, 1997, p. 107-126; Pridham \& Pridham, 1981). As such, most literature describes or analyses the evolution of Europarties, aiming to identify the institutional and political factors that influence this process (e.g. Bardi, 1996; 1997). Claeys and Loeb-Mayer (1979), for example, evaluate the "nature" of the European party federations that emerged in view of the 1979 elections and ask if there is "a step towards the formation of genuine parties" (p. 477). In the 1990s, Hix (1996) and Hix and Lord (1997) identify several phases in the evolution of Europarties. From "optimism" in 1970s following direct elections and "stagnation" in the 1980s in the absence of clear role, to an eventual "renaissance" in 1990s as Europarties took up a role in the negotiations of the Maastricht Treaty.

To evaluate the development of different Europarties more systematically, some authors set out to formulate "criteria or stages to measure progress towards party-political integration” (Pridham \& Pridham, 1979, p. 64). In this respect, Niedermayer's framework (1983) has been influential (see e.g. Dietz, 1997; 2000). He distinguishes between a phase of "contact", during which communication between parties is only temporary; a phase of "cooperation", during which communication is permanent; and a phase of "integration", during which interaction between parties of the same family occurs in a supranational organisation (p. 37). Crucially, the latter phase would be characterised by majority decision making between parties (compare Hix, 1996, p. 321-322). Niedermayer concludes, 
however, that the European federations of the time did not go beyond the cooperation phase. Other authors similarly highlight the weak organisational structures of the Europarties (see e.g. Bardi, 1994).

Indeed, while some research on Europarties up to the late 1990s stresses that Europarties will or have become more relevant (e.g. Bell \& Lord, 1998; Johansson, 1997; Ladrech, 1993; 1997), other research emphasizes that they remain very weak compared to 'real' political parties (e.g. Bardi, 1996; 1997; Hix \& Lord, 1997; Mair, 2000; Niedermayer, 1983). At the time, scholars identified two most important constraints on progress towards real parties at the European level (e.g. Claeys \& Loeb-Mayer, 1979; Pridham \& Pridham, 1981).

First, scholars stress that the primacy of the national political realm is a major constraint on the emergence of Europarties, because it prevents the emergence of party competition between Europarties in the European realm (see Mair, 2000, p. 38-39). Hix (1996, p. 323), for example, points to the institutional arrangements of the EU, in which the executive, the Commission, is appointed rather than elected and the Council is the predominant legislative actor (see also Claeys \& Loeb-Meyer, 1979, p. 468-469). Scholars also mention the focus of the media on national politics (Hix, 1996, p. 324; Pridham \& Pridham, 1979, p. 68).

Second, scholars highlight the heterogeneity of member parties as a limitation to the effective functioning and further integration of the Europarties, both in terms of the structures and ideological positions of member parties (Claeys \& Loeb-Mayer, 1979, p. 464-468; Pridham \& Pridham, 1979, p. 67). Johansson (1997), for example, shows that differences in socio-economic positions and attitudes towards European integration were strong constraints on the formation of an alliance between the EPP and the British Conservatives. Gómez-Reino (2018) shows that strong ideological heterogeneity is also an important cause for the fragmentation of nationalist parties in transnational party forums. And Dietz (2000, p. 204-205) shows how ideological concerns about good party organisation can be a cause for reluctance to give up national sovereignty to a supranational party organisation.

\section{6 | Early 2000s: Studies on the Europeanisation of national parties and the consolidation of Europarties}

In the early 2000s, a new strand of literature moves away from the focus on parties at the European level. Instead, it asks how European integration affects parties at the national level. Some scholars had already inquired into this over the course of the 1990s (e.g. Aylott, 1997; Gaffney, 1996; Guyomarch, 1995; Raunio, 1999b), but their work did not form a "cumulative body of theory" yet (Deschouwer, 2000, p. 21; see Ladrech, 2002). New studies start from the observation that particularly the extension of Qualified Majority Voting in the Council, as well as the increase of EU competences, put national parties "under pressure to adapt" (Carter, Luther \& Poguntke, 2007, p. 7; see also Carter 
\& Poguntke, 2010). Regarding Europarties, new studies show a small change in emphasis from asking how the EU is a stimulus for their development, to asking how Europarties consolidate themselves (Day, 2005, p. 60).

\section{How does European integration impact on national parties?}

In the literature on the impact of European integration on national parties, the concept of 'Europeanisation' is central.6 This concept is much debated (see e.g. Radaelli, 2000; Bulmer, 2006), but in this strand of literature Ladrech's (2002) initial definition of Europeanisation is influential. Ladrech conceptualises Europeanisation of national parties as change in the internal organisation of parties that results from "EU political, social and economic dynamics" (p. 392; see also Carter et al., 2007, p. 4-5). In his call for a new research agenda on national parties and European integration, he formulates five areas of investigation, namely 1) programmatic change, especially in party programmes; 2) changes in the formal or informal organisation of national parties; 3) changing party strategies or the emergence of new parties on the basis of a distinctively pro or anti-EU stance; 4) relations between party members in government and the rest of the party; and 5) transnational cooperation with parties from other EU member states (p. 396-400).

Most literature on the Europeanisation of national parties falls into the first and third of Ladrech's research areas. The vast majority of research is on the first area: the position of national parties towards the EU (e.g. Bakker et al., 2015; Gaffney, 1996; Marks, Wilson \& Ray, 2002; Pennings, 2006). Such research usually highlights that the classical ideological left/right cleavage and the newer Green/Alternative/Libertarian to Traditional/Authoritarian/Nationalist (GAL/TAN) cleavage predict the positions that parties adopt towards the EU (Hooghe, Marks \& Wilson, 2002).

Concerning the third research area, a large group of scholars studies the Eurosceptic attitudes of - often new - national parties (e.g. Kopecký \& Mudde, 2002; Taggart \& Szczerbiak, 2004). In this respect, some argue that European integration has little impact on competition between parties in the national realm (e.g. Mair, 2000; Reif \& Schmitt, 1980). Others show how both mainstream parties and parties on the extremes do employ pro or anti-EU stances as strategies to respond to voters' preferences and to gain electoral support (e.g. De Vries \& Edwards, 2009; Meijers, 2015; Williams \& Spoon, 2015). Indeed, in this respect, Külahci (2012) shows that Europeanisation of national parties does not necessarily go hand-in-hand with Europeanisation of national party systems.

Regarding Ladrech's second and fourth research areas, comparatively little research explores the impact of European integration on national party's organisation and intraparty relations. The most comprehensive comparative case studies focus on the power of party elites, including most importantly government actors, and the power of EU 
specialists, including MEPs (Aylott, Blomgren \& Bergman, 2013; Carter \& Poguntke, 2010; Poguntke, Aylott, Carter, Ladrech \& Luther, 2007). Two interesting findings stand out.

First, scholars argue that party elites become more important in national party organisations when a party is in government (e.g. Raunio, 2002). This is because party elites that hold a government position enjoy an informational advantage over other party members, and especially over back-bench MPs. Moreover, government actors may advance policy initiatives that are too risky in the domestic arena and subsequently " "blame" the outcome on the EU (Ladrech, 2007, p. 201). This advantage is lost once a party returns to opposition.

Second, research suggests that EU specialists, notably MEPs, gain more weight in national parties in particular when that national party is small or in opposition (Raunio, 2000). Poguntke et al. (2007) show that the expertise and information that MEPs can provide is important to opposition parties as a source of information and advice on EUrelated matters. Ladrech (2007), however, draws the more sobering conclusion that "this information and expertise do not enable party elites to directly influence the EU legislative process, or even challenge the incumbent national government in a meaningful manner" (p. 201).

The extent to which national parties exercise control over MEPs is indeed debated. Mühlböck (2012; 2013), for example, finds that MEPs from parties that govern domestically are mostly influenced by their EP party group, and not by the position of the minister from the same national party in the Council (Mühlböck, 2012, p. 625). Rasmussen (2008, p. 1179), however, shows that national parties do control who is sent to Brussels, so that there is little need to subsequently control the daily work of MEPs in the EP. And Senninger and Bischof (2018) argue that national parties even articulate similar issues at the national and the European level. They term this the "transfer of policy issue priorities" between MPs and MEPs (p. 157).

For all that, a key question in the emerging strand of literature on the Europeanisation of national parties is whether observed changes in political parties can really be attributed to European integration. That is, party organisational and programmatic changes may also be part of an ongoing and fore-going process of "professionalisation" (Bomberg, 2002, p. 45). And, as Ladrech (2012) argues, the mere presence of changes in national parties does not prove that European integration is the catalyst for change. To address this, several authors pay explicit attention to how the reality of the EU precisely impacts on national parties (see also Carter et al., 2007; Mair, 2007; Mühlböck, 2012; Raunio, 2002; Van Biezen \& Molenaar, 2012).

\section{Studies on the consolidation of the Europarties after Regulation 2004/2003}

In the early 2000s, literature on Europarties somewhat changes perspective. It focuses less on the impact of further integration on Europarty development, and more on how 
Europarties take up different roles and try to consolidate themselves (Day, 2005, p. 60; see e.g. Delwit, Külahci \& Van der Walle, 2004).

This reflects actual developments in the EU at the time. Regulation 2004/2003, for example, provides Europarties with direct funding from the EU budget. Lightfoot (2006) argues that this regulation stimulated the organisational consolidation of existing Europarties and gave rise to the creation of new parties. In view of the 2004 and 2007 enlargements of the European Union, Bressanelli (2014, p. 163-164) finds that Europarties responded to the enlargement of their membership by strengthening the capacity of their organisations to make decisions and to coordinate with member parties. At the same time, Europarties remained ideologically cohesive. Gagatek and Van Hecke (2014) show that the European political foundations that saw the light of day in 2007 may also strengthen the Europarties.

To understand such consolidation of Europarties, as well as the roles that Europarties fulfil, scholars increasingly emphasize the conceptual and theoretical underpinnings of their research (Day, 2005, p. 60; see e.g. Timuş \& Lightfoot, 2014). First, also in this strand of literature, the Europeanisation approach has been popular. Authors frequently refer to the fifth research area on Ladrech's (2002) agenda about transnational party cooperation. Johansson (2002a), for example, uses the prism of Europeanisation to study the role of Europarties and party families in shaping new European treaties. Other authors employ the concept of Europeanisation to analyse the development of particular European party families, such as those on the far right (Gómez-Reino, 2018) or on the far left (Dunphy \& March, 2013).

Second, several studies turn to other theories or concepts. Revisiting the earlier work on the stages of Europarty development, some studies evaluate the extent to which Europarties are organisationally 'integrated' parties Johansson \& Zervakis, 2002; Lightfoot, 2006). Other authors, instead, draw on models of party organisation or party behaviour that are traditionally employed in the literature on political parties. They evaluate the extent to which Europarties resemble so-called 'catch-all' or 'cartel' parties (e.g. Bardi \& Calossi, 2009; Bressanelli, 2014) or explore the "policy-seeking" character of particular Europarties (e.g. Lightfoot, 2005). Applying approaches from comparative politics to Europarties is, however, contested. This is because Europarties do not have the same calibre as national parties, as they are founded and controlled by national parties (see Lightfoot, 2006, p. 304; Hanley, 2008, p. 22-23).

Third, and finally, only few studies apply general theories not to Europarties as independent actors, but to the national parties that constitute and interact with them. Hanley (2008), for example, employs Principal-Agent theory to understand why and how national parties delegate authority to Europarties. He argues that, overall, national parties have a preference for creating "relatively weak agents" to which they delegate "a number of clearly defined - and supervised - functions" (p. 202). The preferences of parties may, however, vary, most importantly depending on the relative size of parties within their party families and on their domestic opposition or government status (p. 204-210). 
Klüver and Rodon (2012) draw on party behaviour models and coalition theory to explain how member parties "upload" their policy preferences to their Europarty. They find that larger parties, with more legislative resources - measured as seat shares in the EP -, are more successful in shaping the common positions of Europarties than smaller parties.

To this should be added that the election of 'Spitzenkandidaten', or lead candidates, for the position of President of the European Commission, opens up another area of research on the consolidation of Europarties. Hertner (2011b), for example, studies the development of Europarty campaigns in the case of the Party of European Socialists, and explores the use of these campaigns by some of the largest PES member parties. Put, Van Hecke, Cunningham and Wolfs (2016) draw on a theoretical framework for candidate selection in national parties to evaluate the way in which Europarties selected their Spitzenkandidaten in the 2014 elections to the European Parliament. By far most research on the Spitzenkandidaten, however, concerns their salience in the campaigns of national parties and their salience to voters. Literature on both the former (e.g. Braun \& Popa, 2018; Braun \& Schwarzbözl, 2019) and the latter type of salience (e.g. Hobolt, 2014; compare Schmitt, Hobolt \& Popa, 2015) shows that the visibility of the Spitzenkandidaten remains limited.

\section{7| Studies on actual transnational activities of Europarties and national parties}

The previous sections already show that the majority of literature on Ladrech's (2002) fifth research area - "relations beyond the national party system" (p. 399) - focuses on Europarties, and more specifically on the constitutionalisation and institutionalisation of these parties. Nevertheless, there is some literature that explores the actual transnational activities of Europarties or of national parties with a view to EU affairs.

To start with, some studies describe the role of Europarties during treaty negotiations or moments of EU policy change. Several of these studies highlight that there are opportunities for Europarties to influence EU affairs, but that these opportunities are often "missed" (Külahci, 2012, p. 1295). This is due to factors such as ideological differences, the absence of majorities, and national economic and political interests (e.g. Johansson, 2017; Külahci, 2012; Lightfoot, 2005; Van Hecke, 2012). Nonetheless, Johansson (e.g. 2002a; 2002b; 2016; see also Budden, 2002) shows that the European People's Party did play a decisive role in treaty negotiations. Particularly during negotiations for the Single European Act and the Maastricht Treaty, the Europarty facilitated networks, agreements, and common positions between leaders from the Christian-democratic party family. And whereas Van Hecke (2012) finds little influence of transnational parties on the outcome of the Convention on the Future of Europe, he does stress that transnational parties successfully organised networks between MEPs and MPs as a counterbalance to the influence of national governments. 
Another small body of research within the discipline of Political Science studies transnational party activities with a view to EU enlargement and the EU's neighbourhood policy. Most of this literature concerns the influence of Europarties on national parties in Central and Eastern European countries in the process towards EU accession. Conclusions are mixed. Some authors argue that Europarty influence on new member parties is small (e.g. Haughton, 2009, p. 420-421; Holmes \& Lightfoot, 2011), while others find evidence for more substantial impact (e.g. Pridham, 1999a; 1999b; Von dem Berg \& Poguntke, 2013). Chryssogelos (2017) shows how Europarties also promote certain EU interests and norms in countries within the eastern neighbourhood by offering political benefits to national parties, including open political support during moments of domestic conflict. Timus, (2014) additionally argues that the Konrad Adenauer Foundation (KAS), affiliated to the German CDU, played an important role in supporting the Europarty applications of parties in the eastern neighbourhood.

Indeed, a few authors document informal transnational activities by national parties in the EU - and, more importantly, by their political foundations - with a view to their partners in Eastern Europe. Dakowska (2002; 2005), for example, shows how the German political foundations played a key role in creating networks between the Europarties and parties in applicant countries during the period prior to EU accession. They also facilitated an exchange of expertise on EU rules and affairs. Other authors examine practices of international aid by European and American party actors to national parties in developing democracies more generally. These studies, for example, show that the organisation of exchange visits, trainings, and seminars is widespread. In particular aid by political foundations from EU member states often - but not always - occurs along partisan lines. Scholars, however, also agree that the effects of such activities are limited (Burnell \& Gerrits, 2010; Carothers, 2006; Erdmann, 2006).

Finally, a few, mostly historical studies address the transnational relations of or between certain national political parties in the EU. The large majority of these studies are part of the research agendas on the transnational history of European integration and the 'governance turn' in EU studies, both of which emerged in the 2000s (see Kaiser, Leucht \& Gehler, 2010; Mittag, 2006). Authors analyse the historical transnational contacts amongst party leaders and other party officials, usually with a focus on the Western European Christian-democratic and social democratic party families. Although these studies look at different time periods - ranging from the early 1950s to the early 1980s they often flag that transnational party relations were tight and predominantly of an informal nature (see also Costa, 2018a). They also show how networks between national parties contributed to the development of common beliefs and ultimately shaped important decisions. This included decisions about the course of very early European integration (Kaiser, 2007; 2010), the fields of enlargement and development aid in the EC (Salm, 2016), accession to the EC (Gehler, 2010; Steinnes, 2008), and foreign affairs matters (Rathkolb, 2010). 
Table 7 Overview of the academic debate on Europarties and national parties in European integration

\begin{tabular}{|c|c|c|c|}
\hline Origin & Main focus & Main arguments and debates on Europarties & $\begin{array}{l}\text { Main arguments and debates on Europeanisation of } \\
\text { national parties }\end{array}$ \\
\hline $\begin{array}{l}\text { After } \\
\text { direct } \\
\text { elec- } \\
\text { tions } \\
(1979)\end{array}$ & $\begin{array}{l}\text { Emergence of } \\
\text { Europarties }\end{array}$ & $\begin{array}{l}\text { Asks if Europarties develop into 'genuine' parties } \\
\text { - Focus: development of transnational party federations } \\
\text { in the EU } \\
\text { - Debate: about the function and success of the } \\
\text { Europarties } \\
\text { - Argument: Europarties have developed to some extent, } \\
\text { but remain very weak } \\
\text { - Relevant authors: Bardi, 1996; Bell and Lord, 1998; } \\
\text { Claeys and Loeb-Mayer, 1979; Dietz, 2000; Hix and } \\
\text { Lord, 1997; Johansson, 1997; Ladrech, 1993; 1997; } \\
\text { Niedermayer, 1983; Pridham and Pridham, 1981 }\end{array}$ & $\begin{array}{l}\text { Asks how national parties deal with the European Union } \\
\text { - Focus: national parties' stances towards European } \\
\text { integration } \\
\text { - Little empirical research, mostly shows how national } \\
\text { parties have developed positions on EU integration } \\
\text { - Relevant authors: Aylott, 1997; Gaffney, 1996; } \\
\text { Guyomarch, 1995; Raunio, 1999b }\end{array}$ \\
\hline $2000 \mathrm{~s}$ & $\begin{array}{l}\text { Europeanisati } \\
\text { on of national } \\
\text { parties and } \\
\text { consolidation } \\
\text { of } \\
\text { Europarties }\end{array}$ & $\begin{array}{l}\text { Moves towards more theoretically informed analyses of } \\
\text { Europarties } \\
\text { - Focus: consolidation of Europarties and their roles in } \\
\text { the European Union } \\
\text { - Debate: about the function and success of the } \\
\text { Europarties } \\
\text { - Argument: Europarties have further institutionalised } \\
\text { and taken up a more important role in the EU, but are } \\
\text { still weak organisations } \\
\text { - Relevant authors: Bardi and Calossi, 2009; Bressanelli, } \\
\text { 2014; Delwit et al., 2004; Day, 2005; Gómez-Reino, } \\
\text { 2018; Hanley, 2008; Hertner, 2011b; Johansson and } \\
\text { Zervakis, 2002; Klüver and Rodon, 2012; Lightfoot, } \\
\text { 2006; Van Hecke, 2010 }\end{array}$ & $\begin{array}{l}\text { Asks about the impact of European integration on } \\
\text { national parties } \\
\text { - Focus: signs of adaptation to the EU in national parties } \\
\text { - Debate: about the extent to which changes in political } \\
\text { parties can be attributed to European integration } \\
\text { - Argument: national parties show some, but limited, } \\
\text { signs of Europeanisation } \\
\text { - Relevant authors: Aylott et al., 2013; Bomberg, 2002; } \\
\text { Carter and Poguntke, 2010; Ladrech, 2002; Mair, 2007; } \\
\text { Mühlböck, 2012; Poguntke et al., 2007; Rasmussen, } \\
\text { 2008; Raunio, 2002 }\end{array}$ \\
\hline
\end{tabular}


Table 7 (continued)

\begin{tabular}{|c|c|c|c|}
\hline Origin & Main focus & Main arguments and debates on Europarties & $\begin{array}{l}\text { Main arguments and debates on Europeanisation of } \\
\text { national parties }\end{array}$ \\
\hline
\end{tabular}


There are also a few books on the historical bilateral relations between certain political parties, of which mostly social democratic parties in Western Europe. These studies likewise demonstrate the relevance of informal relations between national parties, also in the absence of formal structures for cooperation. Moreover, given their focus on longer periods of time, authors illustrate how certain historical or political events, as well as particular personalities within national parties, negatively or positively impacted longstanding bilateral relationships. Case studies include relations between the Dutch Partij van de Arbeid (PvdA) and the German SPD between 1945 and 1990 (Drögemoller, 2005), and between the Norwegian and British Labour parties in the years after World War II (Insall, 2010).

\subsection{Lacuna in the literature on European and national parties in European integration}

The literature on Europarties and national parties in European integration has by far and large focused on the formal organisational capacities of these parties. When it comes to the Europarties, the major concern has been with the neo-functional question of the extent of Europarties' development into 'real' party organisations at the European level. When it comes to national parties and EU affairs, the major concern has been with their organisational capacities to adjust to European integration. This branch of literature has been heavily influenced by the Europeanisation approach. The conclusions of both strands of literature are rather bleak. Europarties and national parties have developed organisational capacities in EU affairs, but only to a limited extent.

There is, however, a lack of knowledge about the more informal transnational activities of national parties. In the discipline of Political Science, a few studies indirectly touch upon the role of national parties in transnational party networks. This most importantly includes research on the actual activities of Europarties with a view to influencing treaty negotiations, particular policy questions, or EU enlargement (e.g. Budden, 2002; Chryssogelos 2017; Johansson, 2016; 2017; Külahci, 2010), or with a view to developing European election campaigns (e.g. Hertner, 2011b). Also some studies in the discipline of History address the transnational networks of national parties. Importantly, such work illustrates that the interaction between parties that are ideologically close to each other has a "long tradition" (Mittag, 2011, p. 6), and that exchange primarily occurs through informal contacts rather than through formal platforms for cooperation (e.g. Salm, 2016).

Yet most studies on transnational party networks focus on the level of the transnational networks of party leaders or of other actors in the central party office, rather than on the level of individual parties that participate in these networks (e.g. Kaiser, 2010; Salm, 2016). As such, they only provide limited insight into the motivations of, and constraints on, national parties that emanate from the domestic realm. Moreover, the majority of studies on transnational party activities are concerned with constitutional 
questions about European integration, rather than with certain policy areas (Salm, 2016, p. 6; e.g. Gehler, 2010; Johansson, 2017; Van Hecke, 2012). And in studies that analyse bilateral contacts between two national parties, European integration or EU affairs are not a primary issue (Salm, 2016, p. 7; e.g. Drögemoller, 2008). Finally, given the historical focus of most studies on actual transnational party networks, the question remains what such networks look like after various important developments in European integration, including EU enlargement, the further integration of key policy areas, and the "more prominent position" of Europarties (Switek, 2016, p. 737).

\subsection{Conclusion and contribution to the academic debate}

This chapter shows that much progress has been made in research on national parliaments and national political parties in the European Union. Within the traditions of these bodies of literature, scholars have also increasingly paid attention to formats for cross-national and cross-level coordination between parliaments and parties. In particular the body of literature on inter-parliamentary platforms in the EU has grown significantly after the entry into force of the Lisbon Treaty. But also attention to Europarties has gained momentum with the new position Europarties acquired in view of Regulation 2004/2003 and the Spitzenkandidaten process. At the same time, the literature on the organisational adaptation of national parliaments to European integration is much more developed than the literature on the organisational adaptation of political parties. Yet overall, research has led to valuable empirical insights, and to some further development of theoretical and analytical perspectives.

Nevertheless, the conclusions of this chapter about the lacuna in the literature on transnational party activities and inter-parliamentary cooperation echo those of Salm (2016) and Hanley (2008). From his empirical study on the development of transnational parties in Europe, Hanley (2008) concludes that 'much more 'bottom-up' work is required on national parties and their links across frontiers, including bi- and multi-lateral ties” (p. 201). From his brief review of existing research on transnational party networks, Salm concludes that "scholars have failed to systematically analyse the informal dimensions of the cooperation of political parties in the form of transnational networks active in the multi-level European governance system" (p. 7). The current review likewise shows that scholars by far and large study the formal instruments, platforms, and functions of interaction between parliamentary and party actors in the EU. They mostly do so at the level of the formal platforms in place, rather than from the perspective of national parties themselves.

In this dissertation, I thus seek to make a threefold contribution to the literature. First, I contribute to knowledge about informal transnational activities of national parties, both in the context of inter-parliamentary platforms, and in the context of Europarties or EP political groups. This is important, because the existing emphasis on institutionalised platforms of cooperation, and on the formal functions of such platforms, may well lead to 
an underestimation of the actual transnational contacts that take place. Indeed, the nature of decision making in the EU allows for much informality and networking. My focus on the behaviour of national parties, and on the two specific dossiers for transnational activities of EUNAVFOR Med and election campaigns, allows me to move away from the focus on formal institutions.

Second, I explicitly consider the 'politics' of transnational party activities. Most studies on either inter-parliamentary cooperation or transnational party activities have looked at interaction at the supranational or transnational level, paying little attention to how this interaction links back to the national realm. Yet as Johansson (1997) observes, "when the activities of political parties cross state borders, their representatives are not suddenly transformed into free-floating elites. They remain constrained by factors emanating from the domestic arenas of party politics" (p. 220). My "bottom-up approach" (Hanley, 2008, p. 23) starts with observing the practices of individual national parties, rather than those of a group of parties. This helps to better understand the interaction between political activities at the supranational, transnational, and national level. By considering the drivers and constraints on transnational party activities that emanate both from the national and the European realm, I thus cut across the bodies of literature on national parliaments, inter-parliamentary cooperation, and parties in the European Union.

The third contribution of this dissertation is theoretical. The literature on interparliamentary cooperation has long been highly descriptive (Raunio, 2009, p. 324), and much of the literature on actual transnational party activities is mostly historically informed. Scholars do employ some concepts or approaches to interpret the contacts and cooperation within party families. Yet these concepts, including most importantly transnationalism and Europeanisation, do little to understand the particular behaviour and choices of individual parties. This also goes for the conceptual approach of the multi-level parliamentary field in the literature on inter-parliamentary cooperation, which additionally has a strong normative connotation. In the next chapter, I thus develop a theoretical framework to generate expectations about what drives parties to act transnationally and what conditions them in doing so. In so doing, I integrate several of the findings of the literature discussed here. 


\section{Chapter 3}

\section{Theoretical framework}

\section{A resource-dependence perspective on transnational party activities in the European Union}

The aim of this chapter is to develop a theoretical argument about what drives transnational party activities in the European Union, and about what conditions the degree to which parties engage in transnational activities. Thus, I develop a theoretically informed understanding both of the cause of transnational party activities and of the degree of such activities. To do so, I build on insights from Resource Dependence Theory, originally developed by Pfeffer and Salancik (2003[1978]). I combine this with insights from the literature on party organisation and behaviour, as well as from the literature on inter-parliamentary and transnational party cooperation that chapter 2 discusses. The theoretical approach departs from the conceptualisation of national parties as transnational actors that chapter 1 presents.

The purpose of the theoretical framework is to set out the lines of enquiry for the empirical investigation of national parties' transnational activities in the multi-level system of the EU. Rather than advancing strict hypotheses to be 'tested', I develop broader expectations to guide and inform the subsequent empirical exploration. As Hanley (2008, p. 5-6) argues, such a strategy suits the current state of the literature well, because little is still known about the strategies of national parties in transnational cooperation. The strategy also accords to the state of development of transnational party cooperation in the EU. As chapter 1 shows, such cooperation is still very much in flux.

Because Resource Dependence Theory has not previously been applied to understand transnational party contacts, I first discuss the relevance of this framework in view of existing approaches in Political Science. I subsequently introduce the premises of Resource Dependence Theory and discuss how organisations manage the uncertainty they face in their environment. In the second half of the chapter, I relate Resource 
Dependence Theory to transnational activities of political parties in the European Union. Ultimately, I set out a framework to understand the motivations of parties to engage in transnational party activities, as well as three sets of expectations about the conditions under which parties seek transnational contacts.

My core argument is that political parties in the European Union face resource dependencies and establish contacts and relationships with like-minded parties to manage these. I identify such dependencies in view of the vote, office, and policy-seeking behaviour of parties, both at the national and the EU level. The degree to which a political party engages in transnational party activities depends on a number of conditions. These conditions include the position of the party in the national political system, the extent to which the party has access to resources through alternative routes, and the degree of ideological coherence between the party and its sister parties. Table 8 summarises the resource dependencies that can drive transnational party activities, while table 9 brings together the main theoretical expectations. Chapter 7 returns to the theoretical contribution of this dissertation, taking into account the empirical findings of this dissertation.

\subsection{Why this theoretical approach to transnational party activities?}

Pfeffer and Salancik (2003) introduce Resource Dependence Theory (RDT) in The External Control of Organizations, originally published in 1978. RDT is an organisation theory and is related to the group of theories that emphasizes the importance of the environment for organisations, such as contingency theory, population ecology, and neoinstitutional theory (see Hult, 2003). Its basic, core argument is twofold. First, organisations are dependent upon their environment to acquire the resources necessary for their survival. Second, organisations respond to these environmental dependencies by engaging in contacts with other organisations, while seeking to manage their dependence on these organisations (Pfeffer \& Salancik, 2003[1978]).

RDT has subsequently been developed in the context of American literature on private firms and management. Conceptually, this is mostly clearly visible in the options that scholars have formulated for organisations to manage environmental dependencies (for a review, see Hillman, Withers \& Collins, 2009). For example, Pfeffer and Salancik (2003) discuss management strategies such as mergers, joint ventures, and changes in boards of directors. The core logic of Resource Dependence Theory, however, helps to conceptualise relations between organisations and their environment beyond private firms (Davis \& Cobb 2010, 31; Lipson, 2017, p. 81; see e.g. Bouwen, 2002; Fonck, 2018; Rhodes, 1981; Rhodes \& Dunleavey, 1995; Vantaggiato, 2019). 
Shortcomings of existing approaches to understand the response of national parties to their environment

RDT has not previously been applied to the study of transnational party or interparliamentary cooperation. The argument of Fonck (2018) about how resource exchange characterises cooperation between parliamentary and executive diplomats, however, resembles a resource-dependence approach. Pfeffer and Salancik's original work provides a promising framework to study the transnational activities of political parties, because it can address some of the shortcomings of existing approaches to political parties in the European Union.

To start with, many scholars have discussed the alleged decline of political parties. Developments such as European integration, fast changes in political communication and digital media, and declining levels of party membership challenge the role of political parties in representative democracies (e.g. Dalton \& Wattenberg, 2002; Van Biezen, Mair \& Poguntke, 2012). As Mair (1997; compare Mair, 2013), however, observes, political parties also "continue to survive" and remain pivotal actors in democratic systems (p. 8990). A crucial conceptual question is therefore about parties' response to challenges in their environment.

The development of theoretical approaches is an important step to further investigate the relation between parties and their environment (Montero \& Gunther, 2002, p. 15). Yet the Europeanisation approach, which is dominant in the study of political parties and European integration (e.g. Ladrech, 2002; Poguntke, Aylott, Carter, Ladrech \& Luther, 2007; Van Hecke, 2009; compare Aylott, Blomgren \& Bergman, 2013, p. 7), is not well-suited to theorise about the active response of political parties to their environment. The strength of the Europeanisation approach lies in the attention it directs to the EU as a significant element of the "operating environment" of national political parties (Ladrech, 2002, p. 394; see also Carter, Luther \& Poguntke, 2007, p. 9). The approach also recognises that European integration alters the distribution of resources between actors involved in EU decision making (see Börzel, 2002, p. 18-22).

At the same time, however, the concept of Europeanisation directs attention almost exclusively to the effect of European integration on national parties, such as on parties' internal organisations and ability to reach party goals. In so doing, it treats parties as actors that adapt themselves primarily because they are forced to do so by external pressures. Indeed, the fundamental aim of the Europeanisation literature is to conceptualise the EU as a "stimulus" for party change (Ladrech, 2012, p. 576), and to study "adaptational pressure" and resulting "domestic institutional change" (Börzel, 2002, p. 13-42).

Changes in parties, however, do not “'just happen”" (Harmel \& Janda, 1994, 621). That is, national parties do not just 'passively' adapt themselves to European integration. Rather, they have the capacity to actively respond to changes in their environment and to engage in relations with other actors. As Hix and Lord (1997) write, "parties are not completely dependent upon their political and institutional surroundings. [They] possess 
significant political and financial resources that enable them to adapt to their surroundings" (p. 74). Indeed, European integration comes with new opportunities that parties can seize (Bomberg, 2002, p. 46; see also Strelkov, 2015).

An answer to the question of how parties respond to the multi-level EU environment thus requires an understanding of the relations between national parties and other actors in the EU environment, and of how parties are likely to manage these relations (Pfeffer \& Salancik, 2003[1978], p. 257). RDT provides a good starting point to develop such an understanding, because it emphasizes the need for organisations to exchange resources with other actors and helps to understand the resulting interdependent relations that emerge.

\section{How Resource Dependence Theory relates to existing approaches in Political Science}

Some of the core ideas of RDT resonate in theories from the field of International Relations (IR), a sub-discipline of Political Science. Traditional IR theories focus on the role of governments in the international arena. Yet in the 1970s and 1990s, branches of IR literature emerge that challenge this view by bringing transnational networks into focus (Keohane \& Nye, 1972; Rosenau, 1990; see Risse, 2007 for a review). Older work mostly aims to show that transnational activities of non-state actors affect the abilities of states in international politics (Keohane \& Nye, 1972, p. 24). Yet more recent work emphasizes the importance of transnational networks of both state and non-state actors. Such work examines regular cross-national exchanges between public and private actors that may "shap [e] political and social outcomes at home, abroad, and in an emerging global sphere of governance" (Orenstein \& Schmitz, 2006, p. 482). Thus, much like RDT, IR approaches to transnationalism analyse interdependent relations that emerge between organisations in the search for particular societal or policy outcomes (on studies that combine RDT and IR, see Biermann \& Harsch, 2017).

In such IR approaches, national political parties are, however, rarely examined as non-state actors that take part in transnational networks (for exceptions, see e.g. Chryssogelos, 2017, p. 259-260; Johansson, 1999; Smith, 2001). Instead, IR studies on transnational activities by non-state actors focus mostly on multinational companies, experts, non-governmental organisations (NGOs), and social movements (e.g. Cross, 2013; Haas, 1992; Keck \& Sikkink, 1999; Mundy \& Murphy, 2001; Nye, 1974). One clear reason for the lack of attention to national parties is that parties are much more bound by domestic constraints than most other non-state actors. Indeed, as Smith (2001) argues, parties are "essentially domestic political organisations" (p. 59). Problematically, the IR approach to transnationalism provides little insight into the important domestic political constellations that constrain national parties to engage in transnational activities (Johansson, 2004, p. 26). It neither provides much insight into the domestic constellations that motivate parties to do so.

Clearly, an understanding of the interactions of parties across national borders and between levels of government in the EU requires a theoretical approach that allows 
scholars to integrate levels of analysis (Johansson, 2004, p. 18; see also Scharpf, 2001, p. 2ff). RDT is well-suited for this for two reasons. First, contrary both to the Europeanisation approach and the IR perspective on transnationalism, the level of analysis of RDT is that of organisations. As such, RDT provides a tool to theorise about what drives political parties as organisations to engage in transnational interactions. In other words, RDT allows for a focus on the behaviour of national parties as transnational actors in the European Union.

I thus extend the few recent considerations of resource dependence as driver for inter-organisational activities in the literature on European Studies to the transnational activities of national parties. Such previous considerations include research on the lobbying activities of companies and other interest groups in the EU (Beyers \& Kerremans, 2007; Bouwen, 2002), the pooling of resources between expert and regulatory agencies in the EU (Vantaggiato, 2019; Vestlund, 2017), and the diplomatic activities of actors in the European Parliament (Fonck, 2018)

Second, RDT allows for the integration of insights about domestic politics offered by Comparative Politics (CP), the other main sub-discipline of Political Science, to theorise about the specific conditions under which political parties engage in transnational interactions (see Hillmann et al., 2009, p. 1416). CP scholars have developed theories about party behaviour and categorisations of party organisation at the national level. As Johansson (2004) points out, however, these insights from CP have not been integrated in the study of party interactions across levels in the European Union. Therefore:

The remaining and major challenge to future analyses of European party politics more broadly is to define and identify the conditions and circumstances under which political parties are able to act on a multilevel and European basis - and thereby avail themselves of various institutional changes and 'opportunity structures' in the European arenas - given the constraints they suffer. (p. 34).

The resource-dependence perspective on transnational party activities that I develop in this chapter is a first attempt to identify these "conditions and circumstances" (p. 34). I depart from the basic assumption that political parties in the European Union establish contacts with like-minded parties to manage the resource dependencies that they face in view of vote, office, and policy-seeking at the national and the EU level.

\subsection{The basics of Resource Dependence Theory}

An understanding of the relation between organisations and their environment starts with a conceptualisation of organisations as such. In their original approach, Pfeffer and Salancik (2003[1978]) emphasize two basic and inter-related aspects in this regard. First, the authors define organisations by the activities that they perform. This contrasts to 
approaches that define organisations by a common goal or set of goals (p. 23), by the individuals that participate in an organisation (p. 30), or by formal or informal bureaucratic structures (see also Scott, 2003[1981]). To argue that organisations are defined by their activities rather than by their goals is not to say that organisations do not have goals or preferred 'outcomes' (Pfeffer \& Salancik, 2003[1978]). Rather, it is to see organisations as defined by their inter-connected activities to obtain those outcomes. It is also to recognize that individuals within the organisation do not always have the same goals. Different individuals may pressure their organisation to pursue different outcomes (Scott, 2003[1981], p. 29). Ultimately, however, the pursuit of "acceptable outcomes and actions" is a key concern for organisations, because organisations are evaluated by their ability to meet the demands of relevant external actors (Pfeffer \& Salancik, 2003[1978], p. 11).

The latter observation leads to the second key aspect in conceptualising organisations, which is that organisations cannot survive on their own as systems closed to the outside world. Instead, as Katz and Kahn (1966) write, organisations are "flagrantly open systems in that the input of energies and the conversion of output into further energic input consists of transactions between the organization and its environment" (p. 16-17; see also Thompson, 1967, p. 10). Importantly, this perspective on organisations as 'open systems' emphasizes that organisations face a need to acquire resources from their environment to ensure their survival (Pfeffer \& Salancik, 2003[1978], p. 2-3).

In this context, the term 'resources' is broadly understood. Resources can be anything of "tangible or intangible" value that organisations can exchange (Saidel, 1991, p. 544). Organisations can seek to obtain a broad variety of resources depending on their goal. For businesses, typically important resources include investment, sales, staff, and lobbying access (Pfeffer \& Salancik, 2003[1978]). Governments may rely on external actors for the provision of public services, such as health care and education (Saidel, 1991). And public institutions generally face a strong need for skills, expertise, and information from external actors (e.g. Bouwen, 2002; Vestlund, 2017).

The phrase 'resource dependence' thus refers to the situation that organisations depend on external actors to obtain the resources they need. Organisations must "transact with other elements in their environment to acquire needed resources" (Pfeffer \& Salancik, 2003[1978], p. 2). This makes organisations open to pressures from outside. External pressures change when the environment changes, for example when new actors enter the scene or when certain resources become scarce (p. 3).

\section{Emergence of interdependence with actors in the environment}

Because virtually all organisations are dependent upon other actors in the environment, interdependence between organisations emerges. Clearly, some organisations are more resource dependent than others. The degree of resource dependency, for example, depends on an organisations' need for scarce resources (Scott, 2003[1981], p. 118) and on an organisations' capacity to generate resources by itself. Inter-organisational activities are, 
however, rarely unidirectional. Instead, they are usually based on an "exchange relation" between organisations that are mutually dependent upon each other for reaching their goal (Bouwen, 2002, p. 368). Such exchange relations can be symmetrical, when organisations depend on each other to the same extent, or asymmetrical, "when the exchange is not equally important to both organisations" (Pfeffer \& Salancik, 2003[1978], p. 53).

Indeed, Casciaro and Piskorski (2005) argue that Pfeffer and Salancik's original notion of interdependence consists of two dimensions that are both distinct and interrelated. First, mutual dependence refers to the existence of resource dependencies between two or more organisations. It is the sum of the dependencies between actors. This sum of dependencies may change over time with technological, societal, or political developments in the environment of organisations (Pfeffer \& Salancik, 2003[1978], p. 43). Second, power imbalance refers to the situation that an organisation has an advantage over another organisation, because it has more or more important resources. In other words, in a relationship, one organisation may be more dependent than the other. There is thus a difference in "the power of each actor over the other" (Casciaro \& Piskorski, 2005, p. 170). Importantly, such power is not an "attribute" of an actor, but a "property" of a social relation (Emerson, 1962, p. 32).

Importantly, organisations do not engage in exchange relations with just any organisation in their environment. That is, the organisational environment does not include the "entire system" of actors and institutions that somehow affect the capacity of an organisation to carry out its tasks (Pfeffer \& Salancik, 2003[1978], p. 62). Rather, it refers only to those elements with which an organisation can interact and that it can perceive. That is, organisations cannot possibly transact with all elements in their environment given limits to the amount of money and time that they have. They also cannot possibly view all elements in their environment (p. 62), because the 'environment' of an organisation is not a given reality that exists independently of organisations.

How then do organisations know their environment? According to Pfeffer and Salancik (2003[1978], p. 13 and 72), organisations interpret and create their environment, while making differentiations between what is important and what is not. In the context of resource dependence, this involves a consideration of the "actions and reactions" of those actors in the environment that have relevant resources (Lenz \& Engledow, 1986, p. 335-336; Pfeffer \& Salancik, 2003[1978], p. 84-85). Based on an initial, 'naïve' conception of the environment, organisations select and ignore certain pieces of information (Pfeffer \& Salancik, 2003[1978], p. 74). Because organisations are in a constant process of observing and interacting with their environment, they can evaluate and alter their perception when too much environmental information does not match previous beliefs about the environment (see Weick, 1979[1969]). It is thus the environment that organisations can perceive, the "enacted environment", that influences the behaviour of organisations (Pfeffer \& Salancik, 2003[1978], p. 63). In turn, events outside of the 
enacted environment may influence organisations' ability to obtain outcomes (200[1978], p. 63).

Finally, even though individuals within an organisation often rely on the same organisational structures and information systems to acquire resources from the environment, environments may still be different for different individuals or subgroups within an organisation (Pfeffer \& Salancik, 2003[1978], p. 74 and 89). This is a problem to which also open system theorists and neo-institutionalists have drawn attention (Scott, 2003[1981], p. 134; see Powell \& DiMaggio, 1991). Units or individuals within an organisation may have different tasks or immediate goals. This does not only mean that they are likely to face different types of dependence upon the environment, but also that they are in contact with different types of external actors and entities. As such, as Pfeffer and Salancik (2003[1978]) conclude, "it may be more reasonable to speak of different environments, attended to or enacted by different individuals and groups within the organization" (p. 74).

\section{The need for organisations to respond to external social demands}

So far, I have focused on the question of why organisations depend on other actors in their environment. The observation that organisations engage in mutual exchanges of resources, however, also raises the question of the conditions under which an organisation contributes resources to another organisation. In this respect, and crucially, Resource Dependence Theory presumes that actors outside of an organisation only contribute resources if they believe that the outcome the organisation strives for is legitimate. As Pfeffer and Salancik (2003[1978]) explain, based on the argument of Parsons (1956):

since organisations [use] resources, which, presumably, could find alternative use elsewhere, organizations [are] continually being assessed on the appropriateness of their activities and the usefulness of their output. In other words, since organizations [consume] society's resources, society [evaluates] the usefulness and legitimacy of the organization's activities (p. 24).

Thus, although some scholars, including Scott (2003[1981], p. 133), argue that Pfeffer and Salancik "privilege" material resources, Resource Dependence Theory in fact emphasizes that organisations need to acquire non-material support from their environment if they want to obtain resources from external actors. Such support is based on perceived legitimacy. As the quote illustrates, external actors individually evaluate the legitimacy of organisations. At the same time, such evaluations are based on congruence with existing, socially constructed "norms of acceptable behaviour" (Dowling \& Pfeffer, 1975, p. 122). As Suchman (1995) summarises, legitimacy can thus be defined as "a generalized perception or assumption that the actions of an entity are desirable, proper, or 
appropriate within some socially constructed system of norms, values, beliefs, and definitions" (p. 574).

This does not mean that all participants in an exchange relation must agree to work towards the same, ultimate goal that is collectively perceived as legitimate (Pfeffer \& Salancik, 2003[1978], p. 24). Indeed, a key problem for organisations is that different actors in society hold different beliefs about legitimate organisational outcomes, even to the extent that these beliefs are conflictual. As a result, organisations must make choices about which pressures from the environment to ignore and which to attend (p. 27). In so doing, they need to maintain a coalition of social support that is large enough for the organisation to ensure sufficient access to resources (March \& Simon, 1958).

The need for resources from other actors thus makes organisations open to interests and pressures from their environment. That is, the actors that contribute resources to an organisation can make demands towards the organisation. For example, large institutional investors can demand compliance to certain societal values as a prerequisite for investment, such as adherence to standards for transparent financial reporting (e.g. Verbruggen, Christiaens \& Milis, 2011) or equal representation of genders in management boards (e.g. Hillman, Shropshire \& Cannella, 2007). The extent to which an organisation is forced to respond to such demands depends on various factors. These factors include the importance of the resource for obtaining desired organisational goals, the discretion of the outside actor over access and use of the resource, and the availability of alternative sources (Pfeffer \& Salancik, 2003[1978], p. 45-51).

\section{Managing dependence to respond to uncertainty}

Although the title of Pfeffer and Salancik's (2003[1978]) book, The External Control of Organizations, may suggest otherwise, the question that RDT seeks to answer is not primarily about the demands of outside actors towards organisations. Rather, RDT seeks to answer the question of how organisations are likely to respond to external demands ( $\mathrm{p}$. 43). The concept of uncertainty is crucial in understanding this response. That is, resource dependencies and ensuing interdependence between organisations result in "uncertainty" and "unpredictability" (p. 42). This is because organisations cannot be sure "about what the actions will be of those with which the organization is interdependent" (Pfeffer, 1987, p. 26). Such unpredictable exchange relations are problematic, because they create uncertainty about an organisation's capacity to achieve its desired outcomes. As Thompson (1967) writes, "the central problem for complex organizations is one of coping with uncertainty" (p. 13).

In response to uncertainty, organisations seek to "manage" their environment (Hillman et al., 2009, p. 11). Of course, simply complying to the external demands of those actors that hold important resources is possible. Compliance, however, does not only lead to a loss of organisational autonomy, but also to vulnerability vis-à-vis future demands (Drees \& Heugens, 2013, p. 5; Pfeffer \& Salancik, 2003[1978], p. 94-96). Managing dependencies is therefore usually the preferred option of organisations. Such 
managing often consists of the creation of persistent patterns and networks, because preexisting structures of interaction can make relations between organisations and actors more predictable (Pfeffer, 1987, p. 26). This implies that more interdependence with respect to resource dependencies results in "problems of uncertainty regarding outcomes", which, in turn, results in more "interdependence with respect to behaviour" (Pfeffer \& Salancik, 2003[1978], p. 42).

Organisations can manage such uncertainty in two ways. First, organisations can manage their actual resource dependencies with other actors. As Drees and Heugens (2013, p. 5) explain, interorganisational activities can stabilise resource supply in view of mutual dependence and address power imbalances. For example, organisations can engage in strategic alliances or joint strategies with other organisations to pursue shared objectives. Organisations can also take a more radical step and "absorb uncertainty" by merging with an actor on which it is resource-dependent (Davis \& Cobb, 2010, p. 25). However, managing resource dependencies does not always have to involve interorganisational relations. Organisations can, for instance, look for alternative sources for a particular resource, or lobby decision-making authorities to change or introduce constraints on the allocation of certain resources (for a literature review of different strategies, see Hillman et al., 2009).

Second, organisations can manage the social demands of actors on which they are dependent, so as to successfully maintain a coalition of support. On the one hand, organisations can do so without directly engaging in contacts with others. Pfeffer and Salancik (2003[1978], p. 97-106) particularly emphasize the strategic use of information and communication, such as restricting access to information or manipulating the ability of outside organisations to make their demands known. Historical institutionalists, who put more emphasis on dynamics in entire organisational fields, point to the importance of mimicking the behaviour and outlook of other organisations to look legitimate (Powell \& DiMaggio, 1991; on the difference between the RDT and institutional approaches to legitimacy, see Suchman, 1995, p. 575-577). That is, "an organization conforming to norms of strategic behavior demonstrates that it is acting in an acceptable manner and social actors should evaluate it as legitimate" (Deephouse, 1996, p. 1026; see also Dowling \& Pfeffer, 1975).

On the other hand, organisations can manage external social demands through inter-organisational activities, and thereby "stabilize their relations with resourceproviding parties" (Drees \& Heugens, 2013, p. 8). This can take the form of symbolic arrangements or alliances. That is, to maintain a coalition of support, organisations can engage in inter-organisational contacts that symbolise their legitimacy or appropriateness, but that do not as such contribute to organisational efficiency (e.g. Meyer \& Rowan, 1977; Pfeffer, 1981; Suchman, 1995; compare March \& Olsen, 1984). An example of Meyer and Rowan (1977) serves to illustrate this: 
Hiring a Nobel Prize winner brings great ceremonial benefits to a university. The celebrated name can lead to research grants, brighter students, or reputational gains. But from the point of view of immediate outcomes, the expenditure lowers the instructional return per dollar expended and lowers the university's ability to solve immediate logistical problem (p. 355).

Managing external social demands can thus also occur through the development of interorganisational relations, because such relations signal societal acceptance by particular institutions or actors in the environment (see Pfeffer \& Salancik, 2003[1978], p. 193-202). External actors who are regarded as highly legitimate are particularly interesting in this regard (e.g. Baum \& Oliver, 1991; Galaskiewicz, 1985, p. 296-297), because "their legitimacy might 'rub off"' on another organisation (Drees \& Heugens, 2013, p. 7).

\section{Organisational autonomy and the dilemma between stability and flexibility}

Importantly, it also comes with drawbacks to engage in inter-organisational relations - be it to manage actual resource dependencies or to manage the social demands of resourcecontrolling actors. Complying to external demands has the drawback of losing organisational autonomy, but inter-organisational agreements to manage external demands likewise decrease the autonomy of an organisation. Organisational autonomy in this context concerns the ability of an organisation to make own decisions about the use of resources for activities it deems important (Oliver, 1991, p. 944-945). In this regard, Pfeffer and Salancik (2003[1978]) identify the following dilemma:

On the one hand, future adaption requires the ability to change and the discretion to modify actions. On the other hand, the requirements for certainty and stability necessitate the development of interorganizational structures of coordinated behaviors - interorganizational organizations. The price for inclusion in any collective structure is the loss of discretion and control over one's activities. Ironically, to gain some control over the activities of another organization, the focus organization must surrender some of its own autonomy (p. 261).

The dilemma also implies that there can be a trade-off between managing social demands and managing actual resource dependencies. Of course, inter-organisational activities can simultaneously aim at managing resource dependencies and "constitute a symbolic response to institutional pressures" (Drees \& Heugens, 2013, p. 7-8). Yet it may well be that organisations must choose between inter-organisational relations that preserve flexibility to preserve autonomy and relations that create "highly visible linkages with reputed outsiders" to enhance perceived legitimacy (p. 23).

Moreover, given that both types of relations can occur simultaneously, organisations can perform "contradictory activities" (Pfeffer \& Salancik, 2003[1978], p. 
261). This bears some similarity to what more institutional perspectives call "gaps" between the actual activities of organisations and the formal structures through which organisations show allegiance to external demands (Meyer \& Rowan, 1977, p. 355-356). In organisational sociology, the term "organised hypocrisy" likewise refers to organisations that manage a gap between formal decisions and capabilities, and normative "talk" (Brunsson, 1986, p. 171; for applications of this concept in European Studies, see e.g. Cusumano, 2018; Lavanex, 2018).

In view of the dilemma between stability and flexibility, RDT stresses that "organisations purposely strive to avoid the loss of decision-making autonomy" (Drees \& Heugens, 2013, p. 1673). This implies that organisations are averse to establishing interorganisational agreements in so far as these agreements are not necessary to manage the uncertainties that surround access to resources and maintaining a coalition of support (Oliver, 1991, p. 943). The cause of such aversion is that inter-organisational agreements may limit the capacity of an organisation to flexibly respond to demands of actors outside the agreement, as well as to future, yet unforeseen developments in the environment ( $\mathrm{p}$. 945-946). Initial inter-institutional agreements may also well "escalate" if they lead to additional demands (p. 946; Pfeffer \& Salancik, 2003[1978], p. 95). As Drees and Heugens (2013) put it, they "tend to plant the seed for new patterns of interdependence" (p. 5).

Given the uncertainty and complexity of the environment of organisations, however, the relationship between the loss of autonomy and the inclination to engage in inter-organisational relations is not a simple one. Oliver (1991, p. 957-959), for example, shows that other considerations also come into play. These include a search for organisational legitimacy, a consideration of a mutual loss of autonomy and of alternative strategies to acquire resources, and the heuristics involved in making individual decisions about inter-organisational relationships.

Finally, organisations are also likely to create in-house capacities to deal with external dependencies. This, for example, includes the appointment of particular individuals in "boundary-spanning roles", in which these individuals maintain links to outside organisations (Aldrich \& Herker, 1977; see also Schotter, Mudambi, Doz \& Gaur, 2017; Williams, 2002). While this may enhance the capacity of organisations to deal with resource dependencies, it may also attribute power to those in boundary spanning roles, for example because 'boundary spanners' "filter" incoming information (Aldrich \& Herker, 1977, p. 226-228).

\section{3 | Party organisation, behaviour and ideology}

The discussion of Resource Dependence Theory and the role of institutional factors serves as the basis for the development of a resource-dependence perspective on transnational party activities in the EU. In the following, I undertake three steps in setting out this approach. First, I reflect upon the political party as a type of organisation. This also includes a discussion of the 'outcomes' or goals that parties can strive for. Second, I 
discuss which resources potentially create interdependencies between national political parties in the European Union. Third, I draw on some of the literature discussed in chapter 2 to set out expectations about the type of contacts that political parties are likely to seek.

\section{Political parties as flexible and open organisations}

It is not easy to define what a political party is in the context of organisational approaches. As Monroe (2001) puts it, "definitions are as numerous as the authors who write about the parties", not least because there are strong normative beliefs about what parties should do or look like (p. 15). It is not my intention here to provide a single definition of the political party. Rather, I present some conceptual reflections on political parties as a particular kind of organisation. This includes the relation of parties to their environment, the activities they perform, what outcomes they can strive for, and what resources they have. The term 'political party' is used to denote many different things in many different places across the world; what I reflect on here is the organisation of parties in "freely working democratic elections" (Schlesinger, 1984, p. 374).

In line with the conceptualisation of organisations in Resource Dependence Theory, I define political parties by the activities that they perform, rather than by particular bureaucratic structures or by an ultimate political goal (see also Monroe, 2001, p. 17). I view political parties as largely flexible and open organisations that face a need to be responsive to demands and pressures from their environments. Clearly, political parties do have several bureaucratic characteristics, and traditionally parties have indeed mostly been studied in terms of their organisational structure (e.g. Duverger, 1954). For example, political parties have formal party roles, such as chairs and board members; formal organisational structures to facilitate party activities, such as local departments and party statutes; and professional staff with expertise in a variety of areas.

By their very nature, however, political parties are "open structures", not least because "tenure is unstable [and] personal relationships are uncertain" (Eldersveld, 1964, p. 11). Indeed, Sartori (2005[1976], p. 64) emphasizes the importance of sub-units of political parties, arguing that "whatever the organisational - formal or informal arrangement, a party is an aggregate of individuals forming constellations of rival groups". He (2005) also defines parties as "organisational networks" or "groups" that "go far beyond the party itself, for it includes all the 'space' that a party is able to occupy de facto, and no matter under which form, in whatever setting" (p. 8). This "organisational network" is multi-layered. That is, a party is not a unitary actor controlled by party leadership, but rather consists of several layers that are connected through various processes (see also Wolkenstein, Senninger \& Bischof, 2019). 


\section{Katz and Mair's three faces of party organisation}

To analytically distinguish between different layers within political parties, Katz and Mair (1993) identify "three faces of party organisation" (p. 601). In practice, these three faces may "intersect" with each other (p. 601). First, there is the party on the ground, which consists of formal members and "regular activists, financial supporters, and even loyal voters" (p. 597). This dimension of political parties is particularly fluid, because "entry and exit are, for the most part, based on the private choices of the individual members" (p. 597). The party on the ground contributes resources to the party organisation that are important for elections, including labour, money and votes, but can also provide the party with knowledge. For some, it is the party on the ground that provides political parties with legitimacy, because it serves as "the political embodiment of the segment of society that the party as a whole claims to represent" (p. 598).

The second element of the party is the party in central office, which consists of the national executive party office and the central party bureau (Katz \& Mair, 1993). The executive party office may be a rather open structure if top party members come and go. In other cases, however, the executive office may be more of a closed, "self-perpetuating and autonomous elements of the overall party structure" (p. 599) if jobs are divided between long-term party insiders. The central party bureau is usually the most closed and bureaucratic part of the party organisation. Key resources that the party in central office provides to the overall party organisation are expertise and the ability to coordinate the overall party organisation (p. 599-600).

Finally, the third element of the political party is the party in public office. The party in public office is usually viewed as the most important element of political parties. In particular, most scholars emphasize the importance of the party in government office (e.g. Downs, 1957; Monroe, 2001; Schlesinger, 1984). Yet in the multi-party parliamentary systems that are dominant in Europe, political parties may also have a long history of being in 'opposition office' in the national parliament. Because the legitimate existence of political parties is usually coupled to electoral support, holding government office or many opposition seats can be viewed as major party success (Katz \& Mair, 1993, p. 596). This electoral support may, however, be unstable, so that the party in public office may face sudden growth or sudden decline. The party in office is thus very open to outside pressures and developments. Holding parliamentary or government office provides parties with several important resources, namely:

the legal authority to make governmental decisions [..., paid salaries that allow [members] to devote full time to politics [..., experience and expertise [in formal positions] [..., and] access to the expertise and information gathering and processing capabilities of the state bureaucracy. Finally, the party in public office has the legitimacy conferred by a public mandate (p. 597). 
The observation that parties have different "images" (Eldersveld, 1964) has ignited a debate about the different balances of resources between the various party elements. This has led to many scholarly discussions about party types and trends in the development of party models. Parties have historically been categorised into cadre and mass parties (Duverger, 1954). The 'cadre party' broadly refers to a first generation of elite-centred parties focused on the party in public office, while the 'mass party' broadly refers to a second generation of parties with organised mass membership and active involvement of the party on the ground. Scholars have later criticised this distinction and have added other types of parties (e.g. Panebianco, 1988; Sartori, 2005[1976]), including the influential idea of the 'catch-all' party (Kirchheimer, 1966). Simply put, the catch-all party describes a development towards parties that attach little value to ideology so as to increase their potential to receive broad public support (for a review, see Wolinetz, 2002).

Another important addition is Katz and Mair's (1995) thesis of the rise of the socalled 'cartel party'. This entails a twofold argument. First, parties in Western Europe have become highly dependent on the state for their existence. And second, parties tend to form complicit agreements with each other to avoid strong competition on policy issues. They rather base competition on de-politicised "claims to efficient and effective management" and they cooperate to ensure "collective organisational survival" with stable electoral support for all parties in the 'cartel' (p. 19-20).

\section{Strom's model of competitive party behaviour}

The discussion about the various layers and types of political parties is, however, still largely focused on the organisational features of parties. Although this focus is certainly crucial for comparative studies, as such it provides little insight into party activities, nor into the informal aspects of parties (see further Wolkenstein et al., 2019). Indeed, parties are held together not so much by a common organisational structure, but rather by a set of inter-connected activities to obtain certain party goals (see also Monroe, 2001, p. 1718). To better understand party activities, it is helpful to consider different models of party behaviour and the outcomes parties may strive for. An analytical distinction between different party goals can be derived from the work of Strøm (1990), who identifies three models of competitive party behaviour.

First, parties can be vote seeking. In this model of party behaviour - commonly referred to as the 'Downsian party' (e.g. Wolinetz, 2002, p. 151) - parties seek to "maximize their electoral support for the purpose of controlling government" (Strøm, 1990 , p. 566). In other words, the goal of political parties is first and foremost to win elections (see also Downs, 1957; Monroe, 2001; Schlesinger, 1984). Parties formulate and manipulate policy positions to win elections and office (Wolinetz, 2002, p. 151; see also Schlesinger, 1984).

Second, political parties may be office seeking, which means that they seek to "maximize [...] control of elected office" (Strøm, 1990, p. 567), even if this comes at the expense of votes or policy goals (Wolinetz, 2002, p. 152). Because the idea of the office- 
seeking party originates in studies on government coalitions, the term 'elected office' traditionally refers to governmental positions or appointments, such as ministerial office. Office-seeking behaviour may be particularly visible in multi-party parliamentary systems, in which governments often consist of coalitions of parties (Wolinetz 2002, p. 152; see also Budge \& Laver, 1986; Riker, 1962). Yet scholars working on the European Parliament have extended the interpretation of elected office to parliamentary office (Bressanelli, 2012; Whitaker \& Lynch, 2014). That is, parties may pursue certain strategies to form an official parliamentary group so as to gain access to the benefits attributed to parliamentary groups, including speaking time and financial resources.

Third, if a party is policy seeking, its main goal is to "[maximize] its effect on public policy" (Strøm, 1990, p. 597). Policy-seeking parties are thus issue-oriented. As Wolinetz (2002) puts it, "the main characteristic would be that the party more often than not gave greater priority to articulation or defence of its policies than to either the maximization of votes or securing office" (p. 151).

In practice, the various party goals are highly interrelated. For example, parties need votes to obtain seats in parliaments and to be eligible to hold office. Holding office can be a strategy to gain electoral support, not least because it can make a party look trustworthy to voters (Budge, 1994, p. 447). Holding office is also beneficial to obtain desired policy outcomes. It is thus helpful to think about the distinction between the three party goals in terms of more general party "orientations" (Wolinetz, 2002, p. 150). Parties, then, tend to give priority to a specific goal at a specific moment in time (Strøm, 1990). In other words, they move from one point in the 'space' of options to the other.

Importantly, however, Budge (1994, p. 451) points out that the room for manoeuvre of parties to freely pursue different goals is constrained by party ideology. That is, parties do not have sufficient information to calculate the risks involved in seeking to maximise their chances of reaching a particular party goal. As an alternative cognitive framework, parties rely on party ideology to delimit their own "space" within the entire space of possibilities (p. 446). Party ideology, then, can be understood as "a body of normative and factual assumptions about the world, relatively resistant to change, which produces plausible reasons for action of one sort or another" (p. 445-446).7

Finally, it is important to recognise that different layers, sub-units, and individuals within political parties may very well have different orientations or immediate goals. For example, policy success may be most important for the party on the ground, electoral success may be most important for the party in public office, and holding office may be a key goal of the party in central office (Katz \& Mair, 1993, p. 595-600).

\footnotetext{
7 It is beyond the scope of this dissertation to review the large and long-standing debate on the importance, definition, and measurement of party ideology for political parties (see e.g. Mair \& Mudde, 1998, p. 217-220). 


\section{4 | Resource dependencies of national political parties in the European Union}

In this section, I identify the resource dependencies of national political parties in the EU. My argument is that political parties in the EU establish contacts and relationships with like-minded parties to manage the resource dependencies they face. In line with the focus of this dissertation, the discussion focuses on the resource dependencies of the party in central office and the party in parliamentary office. As discussed in section 3.3, these different faces of party organisations are interlinked with each other. For example, the party in central office may have a strong say about the policy priorities of the party in parliamentary office, while those in parliamentary office may be influential in determining the priorities of the central party bureau.

Because national parties can strive to obtain the party goals of seeking votes, office and policy both in the national arena and in the European arena, there are two sets of resource dependencies for each party goal. One set is related to the national level and one set is related to the European level. In line with the approach in RDT, 'resources' are broadly understood. They can be anything that parties need with a view to reaching their goals and that they can exchange or coordinate with sister parties, be it of "tangible or intangible" value (Saidel, 1991, p. 544). Finally, although there are general patterns to interdependencies, resource dependencies are likely to be different depending on the policy area, issue, or even policy dossier at hand. This is why I further elaborate the specific interdependencies between political parties relevant to the two dossiers that I explore in this dissertation in the respective empirical chapters, namely chapter 5 on the European Union Naval Operation Mediterranean, and chapter 6 national and European election campaigns.

The next three sub-sections discuss the main expectations about the resource dependencies that motivate transnational party activities by the party goals of vote, office, and policy respectively. The fourth sub-section discusses the importance for parties to also acquire trans-organisational legitimacy. Table 8 summarises this framework.

\section{Resource dependencies related to vote-seeking}

In the EU's 'multi-level playing field', national parties can seek electoral success both in elections to the national parliament - in bicameral systems most importantly the lower house - and in elections to the European Parliament.8 Direct elections to the EP take place every five years, whereas national elections in the EU member states mostly take place every four or five years. Article 14 of the Treaty on the European Union stipulates that the allocation of seats in the EP proceeds through a degressively proportional system, whereby the smallest member states have 6 seats and the largest have no more than 96 . 
Importantly, even though most national parties become a member of a political group in the EP, national parties run their own national lists with candidates for Member of the European Parliament.9

Although seeking electoral success thus primarily occurs at the national level, national parties may seek to maximise votes at the European level. Such a statement sounds odd, because - except perhaps for the Eurovision song contest - there are no elections that have a European electorate. However, if parties seek votes by promoting a certain political project or political ideology, they are likely to find it important that their sister parties are also successful. This is pertinent especially in the environment of the EU. The size of political groups in the EP depends on the outcome of European elections also in other EU member states, and decision making in general is shared across borders and levels of governance. It is indeed the concern with the electoral success of sister parties that can be an important reason for a party to share resources with sister parties.

Engaging in transnational party activities can thus be a way for national parties to acquire resources to maximise electoral success at the national and at the European level. There are two resource dependencies that are related to maximising votes at the national level and two resource dependencies that are related to maximising votes at the European level.

First, in seeking to maximise electoral success at the national level, parties may seek campaign expertise from sister parties about effective party campaigning. Indeed, parties have faced various systematic challenges, including a decline in party membership (Van Biezen et al., 2012) and changes in the speed with which news reaches citizens (Jacobs \& Spierings, 2016). Moreover, mainstream parties have been challenged by the electoral success of anti-establishment parties (Abedi, 2002). In response to these developments, parties can seek to adapt and professionalise their campaigns (Gibson \& Römmele, 2001). To do so, they may seek campaign expertise from other national parties. Such campaign expertise, for example, includes knowledge and skills related to campaign strategies, techniques, and organisation. Exchanges of campaign expertise can, for example, take place through workshops, mutual visits, or a temporary exchange of party staff (Dolowitz, Greenwold \& Marsh, 1999, p. 720-722).

Second, parties may also be dependent on sister parties to obtain resources related to electoral positions. This, for example, refers to input into the development of a party manifesto for national or European elections. That is, given limited time and resources to prepare election campaigns, parties may resort to using the election manifestos of their sister parties or their Europarties to design their own. In a more sophisticated manner, parties can also seek to obtain knowledge about what electoral positions lead to electoral success (Böhmelt, Ezrow, Lehrer \& Ward, 2016), about the design of a manifesto, or about the core ideological issues in the context of a certain party family (Van Haute, 
2016a, p. 320). Moreover, electoral positions of other parties, be they sister parties or Europarties, can also be used to politicise certain issues in domestic contestation. As Külahci (2010) writes, "national party elites might be helped by Europarty common positions in domestic political struggles with opposition/government parties and/or interest groups leading party elites eventually to politicize an issue for electoral advantage" (p. 1285).

Third, and moving to resource dependencies to seek electoral success at the European level, national parties can develop collective electoral positions. This includes a common election manifesto of the Europarty that is directly accessible to European citizens. Most Europarties publish such an election manifesto, which is negotiated by the member parties. These manifestos usually outline policy priorities and introduce the profile of Europarties. They present citizens with a 'choice', although this is clearly not as advanced as in national election manifestos (see Bressanelli, 2013). Apart from Europarty manifestos, collective electoral positions can also be other common positions or statements, such as press statements or shared media content. These can be issued by a Europarty, but also by a smaller group of parties.

Fourth, and finally, parties can develop collective campaign strategies. Most importantly, this concerns the organisation of a common election campaign through the Europarty. Although Europarties have very few financial resources compared to their largest member parties (Hertner, 2011b, p. 327-328), they can offer a number of other resources. These, for example, include promotional material, rally events, and online campaign content (Gagatek, 2009, p. 35-36 and 69), as well as activities by activists trained by certain Europarties (Hertner, 2011b, p. 338-341). In the European elections of 2014 and 2019, most Europarties also presented lead candidates for the office of President of the European Commission. These Spitzenkandidaten participate in European debates running up to the elections and are present at rallies in member states (see e.g. Braun \& Schwarzbözl, 2019; Hobolt, 2014; Schmitt, Hobolt \& Popa, 2015). As Braun and Popa (2018, 1131 and 1137) show, parties may positively - or negatively, for that matter emphasize this procedure to gain votes.

\section{Resource dependencies related to office-seeking}

Also office-seeking can occur both nationally and at the European level. There are two resources related to office-seeking that national parties may search through transnational party activities.

First, for the purpose of seeking office nationally, parties can seek public legitimacy as a competent government party or legitimate opposition party in the national political system (Poguntke, Aylott, Ladrech \& Luther, 2007, p. 749). That is, engaging in transnational activities can make parties and party leaders look more legitimate (Johansson, 2005, p. 145). Likewise, affiliation to a Europarty or an international party organisation can increase the domestic status of a political parties and be a source of "respectability and successful tradition" (Costa, 2018b, p. 162). At the same time, parties 
may appear less legitimate to the national public if "a national party's ideological identity [...] differs from that of an alliance partner at the European level" (Johansson, 1997, p. 156).

The resource of public legitimacy is important to show respectability as a party in parliamentary office, but particularly so in government office. As McDonnell and Werner (2018) explain, engaging in transnational contacts or alliances may help a party to appear as a respectable coalition partner, or, in other words, as a party that is "coalitionable" (p. 750; see also Startin \& Brack, 2016, p. 41-42). Parties can acquire such public legitimacy, for example, through public statements, the organisation of international conferences or visits, or the formation of transnational alliances. And, notwithstanding controversies over whether or not the Spitzenkandidaten system enhances the democratic legitimacy of the EU (e.g. compare Christiansen, 2016; Fromage, 2019; Gattermann, De Vreese \& Van der Brug, 2016), national parties may promote a European Spitzenkandidat during European elections to foster public legitimacy. That is, parties can present themselves as being capable of running for the office of President of the European Commission (see also Braun \& Popa, 2018, p. 1129-1130).

This dynamic to gain public legitimacy is closely related to vote-seeking behaviour. Indeed, without public legitimacy, voters are unlikely to support a political party. However, the resource dependency is understood here primarily as an aspect of officeseeking behaviour, because it concerns the public legitimacy of a party as a legitimate part of the political system and as a potential, trustworthy coalition partner (compare McDonnell \& Werner, 2018, p. 750).

Second, at the European level, office-seeking national parties may search for access to parliamentary and party resources. They can do so by aligning themselves with or forming a Europarty and political group in the European Parliament. Membership of a formal European party can be an important condition for getting appointed into high-ranking positions, including Presidencies, Vice-Presidencies or Commissioners (see e.g. Peñalver García \& Priestley, 2015). In the EP, members of political groups gain access to the administrative resources of a parliamentary group, as well as also to opportunities to fulfil positions as rapporteur on a policy dossier or chair of a parliamentary committee. National parties may thus join political groups to get access to such benefits of office (Bressanelli, 2012; Startin \& Brack, 2016, p. 401; Whitaker \& Lynch, 2014). In this respect, larger groups are most interesting, as office positions are divided according to the size of the party groups in the EP (Bressanelli, 2012, p. 742). New parties, which are not affiliated to a political group or Europarty yet, may particularly seek such access.

\section{Resource dependencies related to policy-seeking}

In the European Union, competences to make policies are (re)divided between the supranational and the national level. National political parties can thus use two main strategies to influence policy making on European Union affairs. They can seek to influence the position of the national government on an EU matter and they can seek to 
directly influence positions of other actors at the European level. For both strategies, national may seek to obtain a number of resources from sister parties.

First, in those policy areas that are transferred to the EU level, national parliaments no longer have (exclusive) legislative competence. National governments, however, do have legislative competences via the Council of the European Union. To ensure control over the actions of government representatives in the Council, most parliaments have developed new procedures. Yet the type and strength of such procedures strongly differs between national parliaments. In this respect, research shows that individual national parties often lack the resources to effectively scrutinise and control the national government (see chapter 2, sections 2.1 to 2.4). Parties may thus engage in transnational party activities to obtain the necessary resources.

Three resource dependencies stand out. To start with, parties require political expertise about the positions that other governments adopt during negotiations in the Council, as well as about the positions adopted in the EP and the Commission. Sister parties, particularly those that are in government, may have such information. National parliamentarians may also obtain political expertise from discussions at interparliamentary conferences (e.g. Malang, 2019, p. 19; Hefftler, 2015, p. 4).

Additionally, parties require subject-matter expertise about the technical and normative aspects of difficult questions in European politics or of a particular EU policy dossier (e.g. Hix \& Lord, 1997, p. 73; Malang, 2019, p. 19). Such expertise is valuable not only to scrutinise the viewpoint and actions of the national government, but also to aid the development of own policy positions and to formulate the arguments to defend them.

Finally, national parties need procedural expertise, that is, knowledge about the procedures of EU policy making. Because national parties may not always have in-house experts on the EU, they may turn to sister parties or their Europarties for advice. They may also learn about procedures and priorities in policy making at multilateral parliamentary or party meetings (e.g. Miklin, 2013, p. 34-35).

Second, the various institutions and frameworks of the European Union also offer an "intergovernmental and supranational arena in which policy seeking occurs" (Carter et al., 2007, p. 8). This arena may become particularly important to national parties when they cannot pursue their preferences in the national realm. National parties could put pressure on European actors to reach certain policy goals, such as on the European Commission, European Parliament or other national governments than their own (Külahci, 2010).

Because individual political parties usually lack the collective political positions and collective political strategies necessary to create such pressure, parties could seek coordination with other parties. Collective political positions refer to common policy positions. One way to arrive at such positions is through the Europarties. Collective positions, however, do not necessarily have to involve all members of a Europarty. As Külahci (2010) notes, there can be "different types of coalitions (...) between domestic parties within the Europarties" (p. 1286). 
Table 8 | Main expectations about the resource dependencies that motivate transnational party activities (by party goal and level of governance)

\begin{tabular}{lll} 
Party goals & $\begin{array}{l}\text { Resource dependencies related to party goals at the } \\
\text { national level }\end{array}$ & $\begin{array}{l}\text { Resource dependencies related to party goals at the } \\
\text { European level }\end{array}$ \\
\hline
\end{tabular}

- Electoral positions input to the national manifesto for elections or positions to use in national debates (Böhmelt

Electoral success (voteseeking) et al., 2016; Dolowitz et al., 1999; Külahci, 2010; Van Haute, 2016a)

- Campaign expertise knowledge about effective party campaigning (Dolowitz et al., 1999)

Benefits of office (officeseeking)

- Public legitimacy public perception as a legitimate government or opposition party (McDonnell \& Werner 2017; Poguntke et al., 2007; Startin \& Brack, 2016)

- Political expertise knowledge about preferences of EU actors and national governments (e.g. Crum \& Fossum, 2013a; Hefftler, 2015; Malang, 2019; Miklin, 2013)

- Subject-matter expertise knowledge about technical and

Policy success (policy-seeking) normative aspects of EU dossiers (e.g. Crum \& Fossum, 2013a; Hefftler, 2015; Hix \& Lord, 1997; Malang, 2019; Miklin, 2013)

- Procedural expertise knowledge about procedures of EU policy making (e.g. Crum \& Fossum, 2013; Hefftler, 2015; Miklin, 2013)**
- Collective electoral positions common election manifesto and common positions (e.g. Bressanelli, 2013; Külahci, 2010)

- Collective campaign strategies common election campaign and lead candidates (e.g. Gagatek, 2009; Hertner, 2011b; Hobolt, 2014)

- Collective access to parliamentary and party resources acceptance as a member of a party group in the European Parliament and European political party (Bressanelli, 2012; Whitaker \& Lynch, 2014)**

- Collective political positions common policy positions at the EU level (e.g. Külahci, 2010)

- Collective political strategies access to EU decision-making processes and skills to steer EU negotiations (e.g. Van Hecke, 2010; Johansson, 2016)

All party goals Trans-organisational legitimacy to maintain a “coalition of support” and access to resources (Pfeffer \& Salancik, 2003[1978], p. 24-27)

* See also section 4.2, chapter 4, for a discussion of how I arrived at this operationalisation of resource dependencies between political parties in the EU.

** Note that these resource dependencies are not further studied in this dissertation, as they were not found to be relevant as drivers of the transnational activities within the cases explored. See further in chapter 4, section 4.2. 
Finally, the resource of collective political strategies refers to a collective ability to coordinate and steer EU negotiations to a preferred outcome. This can, for example, occur through informal networking during negotiations (e.g. Johansson, 2002a).

\section{The importance of trans-organisational legitimacy}

There is one last resource that needs discussion, namely that of trans-organisational legitimacy. As set out in section 3.2, Pfeffer and Salancik (2003[1978], p. 24-27) emphasize the importance of a "coalition of support" for organisations (March \& Simon, 1958). This refers to a group of external actors on which an organisation can rely for access to resources. These external actors hold beliefs about the legitimate outcomes and appropriate behaviour of an organisation, and they make demands towards the organisation to obtain such outcomes or show such behaviour. Organisations need to manage these external, social demands to maintain a "viable" coalition of support and access to resources (Pfeffer \& Salancik, 2003[1978], p. 25).

For the question about the purpose of transnational party activities of national parties in the EU, this implies that some activities can primarily be symbolic. For example, parliamentarians may attend inter-parliamentary conferences to showcase their involvement and allegiance in a particular field of EU affairs. In this way, they manage external demands about appropriate behaviour and they maintain access to other resources in the future. Indeed, Peters (2017, p. 12-13; see also Herranz-Surrallés, 2014) shows that the creation of the inter-parliamentary conference on the CFSP/CSDP involved various discussions about the symbolic implications of different rules of procedure of the conference. Ultimately, Peters (2017) argues, "the presence of different types of actors [...] has a symbolic effect" (p. 6-7). By being a member of an interparliamentary conference, "actors are established as parliamentary actors of relevance (in that policy field and on that level of political organization)" (p. 7).

A similar argument can be made about other transnational party activities. Gehler (2010), for example, explores the transnational activities of the Austrian Socialist and Christian Democratic parties in the period prior to the accession of Austria to the EU in 1995. He finds that one important driver for networking by party elites was that of "ideological anchoring in largely cross-border policy traditions" (p. 212). In a study on transnational cooperation by radical right parties, Startin and Brack (2016) provide an example of the consequences of a loss of trans-organisational legitimacy. That is, more moderate or "reformed" right-wing parties excluded parties that they considered "too extreme" from the pan-European group 'Europe of Nations and Freedom' (p. 42). The excluded parties thus no longer had access to the resources provided by the group.

In short, national parties may engage in transnational party activities not with the aim to obtain resources for the party goals of vote, office or policy, but with the aim to maintain a 'coalition of support' and future access to resources. Trans-organisational legitimacy thus refers to support for national parties amongst other parties. It is based on 
the perceived legitimacy of the behaviour of a national party and of its party goals (see also Dowling \& Pfeffer, 1975; Meyer \& Rowan, 1977).

\section{5 | Setting out expectations: Under what conditions do parties seek transnational contacts?}

The purpose of this final section of the theoretical framework is to lay down the parameters for the empirical investigation of the transnational activities of national parties in the multi-level system of the European Union. Importantly, chapter 2 shows that current literature provides only few clues about the strategies of national parties as transnational actors, while chapter 1 illustrates that the various avenues for transnational party activities are still very much in development. Therefore, and following the advice of Hanley (2008, p. 5-6), rather than advancing strict and testable hypotheses, my lines of inquiry take the form of broad expectations. That is, they are "educated inferences" that guide and inform the empirical exploration (Schwartz-Shea \& Yanow, 2012, p. 53).

This section thus advances expectations about the conditions under which political parties engage transnational contacts with sister parties to acquire resources. These expectations are based on Resource Dependence Theory. To substantiate them, I also draw on some of the findings of existing literature on transnational party cooperation and inter-parliamentary cooperation that is discussed in chapter 2. Figure 3 summarises the theoretical argument of the previous section.

Figure 3 | Summary of the theoretical argument of what drives transnational party activities

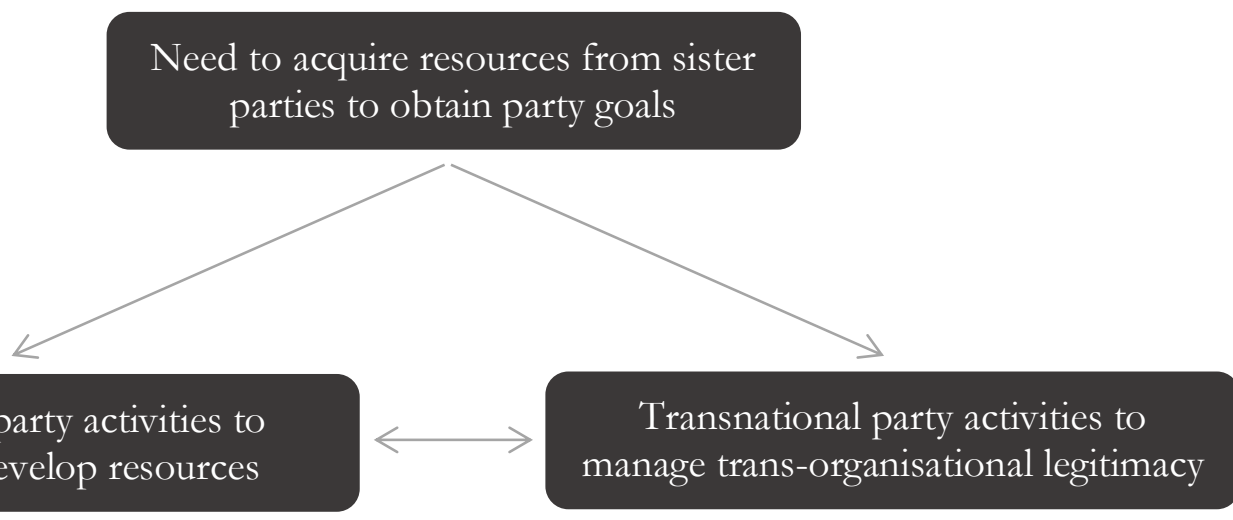

What then, are the system-level conditions that may impact on the extent to which national parties engage in transnational contacts with other parties? In other words, what conditions the 'drive' to acquire resources from sister parties? Three such sets of conditions are likely to be important, namely 1) the position of a party in the national political system, 2) the existence of (alternative) routes to obtain resources, and 3) the ideological coherence of the party family. Table 9 summarises the theoretical argument about what conditions transnational party activities and also specifies the general 
expectations for each type of party behaviour. The sub-sections below discuss each of the three sets of conditions respectively.

\section{The position of a party in the national political system}

The first set of expectations concerns the position of a political party within the national political system. To start with, when it comes to vote-seeking behaviour of political parties, the position of a party vis-à-vis its electorate likely conditions the extent to which a party engages in transnational party activities to acquire vote-seeking resources. That is, compared to parties with stable electoral support, parties that face changes in their electorate have a more urgent need to learn about new ways to campaign and to adopt new electoral positions.

This especially concerns changes that involve a decline in electoral support (Gibson \& Römmele, 2001; see also Tenscher \& Mykkänen, 2014, p. 36-38; Tenscher, Mykkänen \& Moring, 2012, p. 150). Dolowitz et al. (1999), for example, show how the British Labour Party and the US Democrats both perceived a shift to the right by their electorate. To respond to this perceived challenge, the parties mutually exchanged expertise about effective party campaigning in such a political context (p. 720-722). Labour also borrowed ideas about social policy from the Democrats to challenge public perceptions that, being a left-wing party, it would be fiscally irresponsible (p. 722-725; see also Böhmelt et al., 2016).

With respect to office-seeking behaviour, the resources of public legitimacy and collective access to parliamentary resources are likely to be most relevant to new political parties. Indeed, research shows that particularly new radical right parties in the European Union have searched both public legitimacy and access to the benefits of a parliamentary group in the EP by forging new alliances or joining existing ones (McDonnell \& Werner, 2018; Startin \& Brack, 2016). There is anecdotal evidence that this also led to conflicts between new and existing national parties with a view to public legitimacy. In the Netherlands, for example, the Christian Union left the EP political group of the European Conservatives and Reformists (ECR) after the arrival of the far-right party Forum for Democracy (FvD), as it did not want to be associated with the FvD (see e.g. Van den Dool, 2019).

The search for public legitimacy is also more urgent for parties that seek to obtain government office without - recently - having been in office before. If elections are competitions for government office10, then government parties have an advantage in this competition. This is because government parties can advance their ideas through official channels and they usually receive more media attention (Walter, Van der Brug \& Van Praag, 2014, p. 553). As a result, government parties can rely on an "established reputation" as a party that is capable of holding government office (p. 553). Opposition 
parties that aspire to become part of the government would have to build such an image of 'suitability' as government incumbent, given that newly occupying government office comes with important challenges (see e.g. Heinisch, 2003, p. 101-102). Engaging in transnational party activities can be one way to showcase or develop perceived suitability, particularly if sister parties do occupy government office (e.g. Böhmelt et al., 2016).

Finally, regarding policy-seeking behaviour, the position of a party in government or in opposition impacts on the extent to which a party is resource-dependent on sister parties in seeking to influence policy making. As Ladrech (2007) observes, the information and expertise available to the government is "far more extensive" than that available to the parliament (p. 203). Government parties have more and easier access to the policy-making resources available in the national executive. Opposition parties, in turn, are more dependent on other sources of information. As Johansson (1997) writes, "the transnational channels provided by alliances with like-minded parties are important for opposition parties since they are not in control of the governmental machinery" ( $p$. 214). Contacts to sister parties can, for example, provide opposition parties with information about debates and government positions in other member states. And, if sister parties occupy government office, about negotiations in the Council of Ministers (Miklin, 2013, p. 26-27).

A similar argument goes for the ability of national parties to influence decision making at the European level. Through their governments, government parties have direct access to EU negotiations, while opposition parties do not. Particularly for the latter, engaging in transnational party activities can thus be a relevant way to promote and influence policies (Miklin, 2013, p. 27). Hix (1996) discusses one example of this. He writes that Europarties can provide parties that are "out of office in the national arena" with a "back door" into inter-governmental conferences on treaty change (p. 319; see also Johansson, 2016). Miklin (2013) provides the example of coordination by the Austrian Green party. When the party was in opposition, it attributed high importance to resolutions agreed in the Council of the European Green Party as "a basis for further common actions in NPs and the EP" (p. 34).

From this discussion, three expectations can be derived. Expectation 1.1 is that, with a view to vote-seeking, parties that face a changing electorate have more incentive to engage in transnational party activities. Expectation 1.2 is that, with a view to office-seeking, newly established parties and parties that seek to obtain government office after a period of being in opposition have more incentive to engage in transnational party activities. And expectation 1.3 is that, with a view to policy-seeking, opposition parties have more incentive to engage in transnational party activities than government parties.

With regard to the empirical case studies on the transnational party activities of the SPD, the Left and the Greens, these expectations imply that the opposition parties, namely the Left and the Greens, have more incentive to engage in transnational party activities with a view to policy-seeking. In turn, the SPD has more incentive to engage in 
transnational party activities with a view to vote and office-seeking, given its declining electoral support and endeavours to regain government office.11

\section{The existence of (alternative) routes to obtain resources}

When national political parties face resource dependencies, clearly, their strategy to manage these dependencies does not necessarily involve transnational contacts to sister parties. The extent to which national parties turn to their sister parties is likely to be conditioned by two general factors, namely one related to alternative ways to obtain resources, and one related to the availability of sister parties with relevant resources.

First, political parties often have many contacts in wider society, for example to press, think tanks, labour unions, NGOs, and other interest groups (see e.g. Allern, 2010; Heaney, 2010; Thomas, 2001a). Such contacts may allow political parties to acquire extensive resources related to vote and policy-seeking. This includes expertise about party campaigning and, in particular, expertise about policies and policy areas. Indeed, with regard to the latter, in many European countries there are historical allegiances between interest groups and political parties, such as between labour unions and social democratic parties, and between farmer's union and agrarian parties (Allern, 2010, p. 4). Although formal inter-organisational linkages between such groups and political parties have generally declined (Thomas, 2001b), informal and personal contacts can still be widespread and influential (Allern, 2010; see also Beyers, De Bruyker \& Baller, 2015). Also in view of office-seeking, political parties may well rely on other external actors than sister parties to acquire public legitimacy, such as on celebrities (see e.g. Street, 2012).

Moreover, some parties maintain large administrative structures and political foundations of their own through which they can generate resources. The German political parties in particular have large organisations and adjacent foundations. Through this 'in-sourcing', parties may face fewer resource dependencies on external actors. In turn, parties with few resources of their own are likely to face more resource dependencies on external actors, including on sister parties and Europarties. In view of European elections, for example, small parties with only few staff members may not have the capacity to develop a European manifesto (see e.g. Van Haute, 2016a, p. 320). An important qualification to this argument is, however, that parties with very few resources are unlikely to have the ability to engage in transnational activities in the first place. As Vantaggiato (2019) observes in the case of regulatory agencies, for organisations that are "highly constrained (...), the benefits of networking may not outweigh the costs" (p. 2).

Second, it is most interesting for political parties to engage in contacts with those sister parties that have relevant resources. For example, with a view to policy-seeking, if sister parties likewise have little political expertise, because they are also in opposition or

11 Chapter 4, section 4.3, as well as the second sections of chapter 5 and 6 respectively contain data and further explanations about the variation between the SPD, the Left, and the Greens with regard to the theoretical expectations. 
have fewer parliamentary prerogatives, there is little added value to transnational activities. Sister parties that are in government or that have easier access to in-house information, are hence more attractive partners. As large government parties, the German SPD and the Christian Democratic Union/Christian-Social Union (Christlich Demokratische Union/Christlich-Soziale Union, CDU/CSU), for example, have this status within their party families.

A similar argument can be made regarding resource-dependencies in view of vote and office-seeking. Regarding vote-seeking, parties with relevant electoral positions and campaign expertise are those parties that have been electorally successful. Böhmelt et al. (2016), for example, show that national parties "learn from and emulate the policies of successful political parties in other countries" (p. 407). To explain this, they argue that the degree to which a foreign party is successful serves as a useful "heuristic" for decision making (p. 400). In their words, "the foreign party's success (or failure) may come more readily to mind than complex and uncertain calculations about the party's home domain" (p. 400). This is also likely to be the case for the use of campaign strategies of sister parties as example for the design of campaign strategies at home (see e.g. Dolowitz et al., 1999).

Regarding office-seeking, for newly established parties or parties that newly seek to obtain government office, sister parties with relevant public legitimacy that may "rub off" are those parties that are already in parliament or in government (Drees \& Heugens 2013, p. 7). Again, if such 'successful' parties do not exist in the party family, engaging in transnational party activities to acquire these resources has little relevance.

This leads to general expectation 2.1 that parties with many alternative networks or much in-house capacity to generate resources have less incentive to engage in transnational party activities and general expectation 2.2 that parties are more likely to engage in transnational party activities with sister parties that have relevant access to resources.

These expectations imply that the SPD has less incentives to engage in transnational party activities than the Left and the Greens, given its substantially larger inhouse resources. At the same time, the SPD has more sister parties with relevant access to resources than the Left and the Greens.

\section{The ideological coherence of the party family}

Beyond directing attention to resources as 'drivers' for inter-organisational exchanges, Resource Dependence Theory also stipulates that an outside organisation will share resources with another organisation only if it perceives the outcome that the latter strives for as appropriate (Pfeffer \& Salancik, 2003[1978], p. 24). For transnational party activities, this implies that parties are unlikely to exchange resources with each other when they do not share the same view. In other words, when faced with resource dependencies, national parties establish contacts with like-minded parties to overcome these.

Such like-minded parties are usually parties that ascribe to the same party ideology. This is because party ideologies play a crucial role in differentiating between appropriate 
and inappropriate policy goals. As Miklin (2013, p. 28) writes, cooperation between political parties requires a degree of "trust and overlap of interests" and "cooperation in the party channel therefore is much more likely to proceed between parties that share similar views in various areas" (p. 28). Dolowitz et al. (1999) similarly find that the transfer of campaign strategies and policies between the US Democrats and British Labour Party in 1990s was most crucially facilitated by "shared ideology", as this meant that the parties had a "similar perception of policy problems" (p. 726).

This leads to the formulation of a twofold argument about the degree to which parties engage in transnational party activities in view of both policy-seeking, vote-seeking and office-seeking behaviour. First, when faced with resource dependencies, strong ideological coherence within a party family will lead parties to seek broad cooperation through multilateral channels, most importantly Europarties. This is because resources can be more easily and widely exchanged through multilateral networks. Resources to collectively reach goals at the European level are also likely to be more important, including collective electoral positions and strategies, access to collective parliamentary and party resources, and collective political positions and strategies.

Second, weak ideological coherence or ideological disputes within a party family will make informal and bilateral cooperation a preferred avenue for national parties. That is, even in the absence of general agreement within the party family, there may still be individual parties, or groups of parties, that share similar beliefs (Külahci, 2010, p. 1286). Resources to collectively reach goals at the European level are, however, likely to be more difficult to attain.

Ideological coherence in this context may concern overall coherence, because of the need for trans-organisational legitimacy. Put differently, if ideological differences grow too large, there may be a risk that a party can no longer maintain a coalition of support. In the running up to the 2019 European elections, this situation, for example, occurred between the EPP and Fidesz-Hungarian Civic Alliance (Fidesz-Magyar Polgári Szövetség, Fidesz) of Hungarian prime minister Viktor Orbán (see e.g. Brzozowski, Rios \& Fortuna, 2019). Yet even if there is general ideological coherence in a party family, there can still be "problems of congruence" on particular issues or policy areas (Johansson, 1997, p. 216). Külahci (2010) provides one example of this. He shows that conflicts about social democracy and fiscal competition in the Party of European Socialists were "aggravated by substantive ideological preferences" (p. 1293). Thus, there is also a strong issue-specific aspect to ideological coherence.

In short, general expectation 3 is that parties are more likely to seek cooperation through multilateral channels when ideological coherence within their party family is strong, while they are more likely to rely on bilateral cooperation when ideological coherence is weak.

Overall, this expectation implies that the SPD is more likely to seek cooperation through multilateral channels than the Greens and the Left, as it is ideologically positioned more closely to its sister parties. 
Table 9 | Main expectations about the system-level factors that condition transnational party activities (by party goal)

\begin{tabular}{|c|c|c|c|}
\hline & $\begin{array}{l}\text { Position in the national } \\
\text { political system }\end{array}$ & $\begin{array}{l}\text { Existence of (alternative) routes to obtain } \\
\text { resources }\end{array}$ & $\begin{array}{l}\text { Ideological coherence of the party } \\
\text { family }\end{array}$ \\
\hline $\begin{array}{l}\text { Transnational } \\
\text { party activities } \\
\text { related to vote- } \\
\text { seeking }\end{array}$ & $\begin{array}{l}\text { (1.1) Parties that face a changing } \\
\text { electorate have more incentive } \\
\text { to engage in transnational party } \\
\text { activities }\end{array}$ & $\begin{array}{l}\text { (2.1) Parties with many alternative networks or } \\
\text { much in-house capacity to generate vote- } \\
\text { seeking resources have less incentive to engage } \\
\text { in transnational party activities } \\
\text { (2.2) Parties are more likely to engage in } \\
\text { transnational party activities with successful } \\
\text { vote-seeking sister parties }\end{array}$ & $\begin{array}{l}\text { (3) Parties are more likely to seek } \\
\text { cooperation through multilateral } \\
\text { channels when ideological coherence } \\
\text { within their party family is strong, } \\
\text { while they are more likely to rely on } \\
\text { bilateral cooperation when ideological } \\
\text { coherence is weak }\end{array}$ \\
\hline $\begin{array}{l}\text { Transnational } \\
\text { party activities } \\
\text { related to office- } \\
\text { seeking }\end{array}$ & $\begin{array}{l}\text { (1.2) Newly established parties } \\
\text { and parties that seek to obtain } \\
\text { government office after a period } \\
\text { of being in opposition have } \\
\text { more incentive to engage in } \\
\text { transnational party activities }\end{array}$ & $\begin{array}{l}\text { (2.1) Parties with many alternative networks to } \\
\text { generate office-seeking resources have less } \\
\text { incentive to engage in transnational party } \\
\text { activities } \\
\text { (2.2) Parties are more likely to engage in } \\
\text { transnational party activities with successful } \\
\text { office-seeking sister parties }\end{array}$ & $\begin{array}{l}\text { (3) Parties are more likely to seek } \\
\text { cooperation through multilateral } \\
\text { channels when ideological coherence } \\
\text { within their party family is strong, } \\
\text { while they are more likely to rely on } \\
\text { bilateral cooperation when ideological } \\
\text { coherence is weak }\end{array}$ \\
\hline $\begin{array}{l}\text { Transnational } \\
\text { party activities } \\
\text { related to policy- } \\
\text { seeking }\end{array}$ & $\begin{array}{l}\text { (1.3) Opposition parties have } \\
\text { more incentive to engage in } \\
\text { transnational party activities } \\
\text { than government parties }\end{array}$ & $\begin{array}{l}\text { (2.1) Parties with many alternative networks or } \\
\text { much in-house capacity to generate policy- } \\
\text { seeking resources have less incentive to engage } \\
\text { in transnational party activities } \\
\text { (2.2) Parties are more likely to engage in } \\
\text { transnational party activities with sister parties } \\
\text { that have relevant access to policy-seeking } \\
\text { resources }\end{array}$ & $\begin{array}{l}\text { (3) Parties are more likely to seek } \\
\text { cooperation through multilateral } \\
\text { channels when ideological coherence } \\
\text { within their party family is strong, } \\
\text { while they are more likely to rely on } \\
\text { bilateral cooperation when ideological } \\
\text { coherence is weak }\end{array}$ \\
\hline
\end{tabular}




\section{Chapter 4}

\section{Research Design \\ Methods, case selection and data}

This chapter presents the research design of the dissertation. It provides the methodological basis for the empirical chapters 5 and 6 . The research follows a qualitative, exploratory strategy. Most importantly, this means that I explicitly recognise that this inquiry is a tentative one. I do not pretend to provide a generalisable, conclusive answer about transnational party activities of national parties in the European Union. Rather, I provide a first insight into the phenomenon, probing into the plausibility of my theoretical propositions. This approach is warranted given that transnational party activities of national parties in the European Union are under-researched both empirically and theoretically, as chapter 2 reviews. It is also warranted given that the context to transnational party activities is still very much in flux, as chapter 1 shows (see also Hanley, 2008, p. 5-6).

The three left-wing German political parties under scrutiny, namely the SPD, the Greens, and the Left, show important variation with regard to the theoretical expectations. They are also substantively important cases of national parties engaging in transnational party activities in the European Union. This is not least the result of their sheer size and organisational capacities, and of the centrality of Germany in EU decision making. I furthermore identify two dossiers to observe the practices of transnational party activities of the three parties, namely the highly contested military operation to combat human trafficking in the Mediterranean Sea, EUNAVFOR Med, and election campaigns for national elections (2013 and 2017) and European elections (2014 and 2019).

I explore the case studies through a comparative analysis. I employ a "structured, focused comparison", in which I examine similarities and differences both across cases and within cases (George \& Bennett, 2004, p. 67ff). I collect data through semi-structured 
interviews and triangulate the interviews with other sources. Overall, this strategy is wellsuited to answer questions about the behaviour, motivations, and perceptions of actors.

In the following, I first discuss what the exploratory strategy entails. I subsequently set out the approach to operationalisation that results from this strategy. I then discuss case selection. This section includes data about the SPD, the Left, and the Greens with regard to the expectations of the theoretical framework. I also introduce the two dossiers for transnational party activities that are part of the inquiry. Finally, I discuss the methods of analysis and data collection. This includes an overview of the forty semi-structured interviews that the exploration draws on (see also annex 1).

\section{1 | Research approach: An exploratory strategy}

One of the favourite arguments of social scientists is about the questions of how scholars can know about and study social phenomena (for a discussion, see e.g. Moses \& Knutsen, 2007). When it comes to qualitative research strategies in Political Science, the biggest argument is between those who believe that qualitative research should follow the same objectives and strategies as quantitative research (King, Keohane \& Verba, 1995), and those who believe that qualitative and quantitative approaches are "alternative cultures [with] own values, beliefs and norms” (Mahoney \& Goertz, 2006, p. 227). The current inquiry falls within the second broad perspective. Additionally, it follows an exploratory strategy. This implies several choices.

Firstly, I primarily adopt a “"causes-to-effects' approach to explanation” (Mahoney \& Goertz, 2006, p. 230-232). This means that I seek to explore why a certain case shows a certain outcome. Specifically, I explore why a particular political party engages in much transnational party activities on a particular dossier and why another party does not. This contrasts to "effects-of-causes" approaches to explanation, which start by deductively hypothesising about potential causes and then systematically test how much effect each cause has on an outcome (p. 231). Gattermann (2014), for example, adopts such an approach to explaining inter-parliamentary cooperation. She estimates the effect of majority/minority status of EP political groups, political group size and cohesiveness, and Eurosceptic ideology on attendance rates of MEPs at Joint Parliamentary Meetings (JPMs).

Secondly, my explanations are "of a provisional character" (George \& Bennett, 2004, p. 90-91). Of course, and as is common in case study research, my study ultimately aims to contribute to a better understanding of a broader phenomenon. That is, by looking at certain instances of transnational party activities, I aim to better understand national parties' transnational party activities in general. A crucial qualification to this aim, however, is that it is in the nature of exploratory case studies that any conclusions about the wider phenomenon are tentative. Given limited variation between the case studies and little previous research, I can ultimately not be sure about in how far my inferences "exten[d] beyond the unit under study" (Gerring, 2004, p. 347). 
Thirdly, my theoretical approach "supports" and guides the exploration (Toshkov, 2016, p. 82). This contrasts to effects-of-causes approaches, which hierarchically test hypotheses with the goal to ultimately retain or reject these hypotheses. It also contrasts to purely inductive approaches, such as grounded theory, which construct theory on the basis of empirical observations (see e.g. Charmaz, 1996). Rather, my prior theoretical expectations are an informed idea about where to start looking to understand the phenomenon of transnational party activities. Theory serves as the tool to structure and interpret the empirical findings; it provides a conceptual lens. My approach thus implies that I "do not [approach] observations in a theoretically neutral way" (Mahoney \& Goertz, 2006, p. 241). Some pieces of empirical information are more important as evidence in favour or against my theoretical expectations than other pieces of information (see e.g. Collier, 2011).

Fourthly, and relatedly, my exploratory study is a sort of "game" in which I go back and forth between empirical data and theory, trying out and generating new ideas (Toshkov, 2016, p. 33). This means that I deductively arrived at some theoretical propositions, but also inductively adjusted others (see section 4.2). The purpose of a combination of deductive and inductive reasoning is simply to arrive at a better explanation of the outcome of interest (Mahoney \& Goertz, 2006, p. 242). The inspiration from a theory that originates in the field of Business and Management studies, discussed in chapter 3, adds to this 'game' and generation of ideas. Importantly, the exploratory strategy does not exclude an investigatation of existing presumptions about transnational party cooperation in the EU, such as regarding different interests of opposition and government parties (e.g. Hefftler, 2015; Miklin, 2013; compare Malang, 2019).

\subsection{Operationalising transnational party activities, resource dependencies and system-level conditions}

The research project requires an operationalisation at three levels: at the level of transnational party activities in the EU (the outcome to be explained), at the level of the identified resource dependencies that drive these activities (the causes of the outcome), and at the level of the identified system-level factors that condition these activities (the conditions for the cause). At the same time, the exploratory approach requires an openness to new insights. Therefore, after developing an initial analytical and theoretical framework, I allowed for the further development of concepts and indicators "to take place during fieldwork" (Schwartz-Shea \& Yanow, 2012, p. 50). This results in the following approach to operationalisation.

\section{Operationalising transnational party activities}

Chapter 1 identifies four avenues for transnational party activities in the EU on the basis of prior research, namely Europarties, EP party groups, inter-parliamentary conferences, and the organisational structures of national parties themselves. These avenues to 
transnational activities were maintained throughout the research project, with one important adjustment. I initially dismissed interaction with the own national delegation in the European Parliament as an instance of transnational party activities, because this interaction does not involve contacts across nationalities. Many interviewees, however, brought up contacts with MEPs or party staff from their own party in Brussels when they were asked about their contacts across national borders. Indeed, interaction with the own national EP delegation crosses a level of decision making (see also Miklin \& Crum, 2011). I hence ultimately included this as an avenue to transnational party activities.

Within the framework of the four avenues, I defined transnational party activities as "any form of interaction between political parties from the same party family" (chapter 1, section 1.1). 'Transnational party activities' thus include activities as diverse as attendance of conferences or councils, meetings in person, video conferences, phone calls, and e-mail exchanges (see also Miklin, 2013, p. 26). During my interviews, I hence used the general terms 'contacts' or 'being in touch' to ask about transnational activities.

On forehand, I broadly defined informal transnational party activities as contacts that "are based on informal rules of interaction, often involve a limited number of actors, have no final outcome, and are not publicly reported" (chapter 1, section 1.1; based on Reh, Héritier, Bressanelli and Koop, 2013, p. 1115-1117). In practice, formal and informal transnational party activities indeed manifested themselves in these terms. Interviewees most importantly interpreted informal activities as those activities that are not public. Both formal and informal transnational party activities, however, had final and openended outcomes. The interviews also provided a number of additional insights into what practices of formal and informal transnational activities look like. Table 10 summarises the different manifestations of formal and informal transnational party activities.

Table 10 | Different manifestations of formal and informal transnational party activities based on the interpretation of interviewees

\begin{tabular}{ll}
$\begin{array}{l}\text { Practices of formal transnational } \\
\text { party activities }\end{array}$ & $\begin{array}{l}\text { Practices of informal transnational } \\
\text { party activities }\end{array}$ \\
\hline
\end{tabular}

\begin{tabular}{lll}
\hline $\begin{array}{l}\text { Means of } \\
\text { interaction }\end{array}$ & $\begin{array}{l}\text { Usually in person or via video } \\
\text { conferences }\end{array}$ & $\begin{array}{l}\text { Usually through a phone call or via e- } \\
\text { mail, but also during (preparatory) } \\
\text { meetings in person before or during } \\
\text { conferences or events }\end{array}$ \\
\hline $\begin{array}{l}\text { Number of } \\
\text { participants }\end{array}$ & $\begin{array}{l}\text { Mostly multilateral (at least three, but } \\
\text { usually more parties involved) }\end{array}$ & $\begin{array}{l}\text { Mostly bilateral (with only one sister } \\
\text { party), sometimes multilateral }\end{array}$ \\
\hline $\begin{array}{l}\text { Initiator } \\
\text { Often an external institution or } \\
\text { organisation at the European level, } \\
\text { such as a Europarty, EP party group, } \\
\text { or inter-parliamentary conference }\end{array}$ & $\begin{array}{l}\text { Often a particular political party, MP, } \\
\text { MEP or staff member of a national or } \\
\text { European party }\end{array}$ \\
\hline $\begin{array}{l}\text { Frequency of } \\
\text { meetings }\end{array}$ & $\begin{array}{l}\text { At a regular interval } \\
\begin{array}{l}\text { Complexity } \\
\text { (Kuper, 2006, } \\
\text { p. 93-94) }\end{array}\end{array} \quad \begin{array}{ll}\text { Usually complex, involving party staff } \\
\text { or representatives both from member } \\
\text { states and 'Brussels' }\end{array}$ & $\begin{array}{l}\text { Usually simple, involving interaction } \\
\text { either across national levels or across } \\
\text { the national and European level }\end{array}$ \\
\hline
\end{tabular}




\section{Operationalising resource dependencies that motivate transnational party activities}

The framework of resource dependencies that motivate transnational party activities in the EU is presented in table 8 of chapter 3 . These resource dependencies were initially identified based on existing literature about transnational party and inter-parliamentary cooperation. I subsequently explored the resource dependencies both at the conceptual and at the indicator level. In other words, drawing on first interview findings, I probed into the plausibility of the resource dependencies that I initially identified and adjusted the framework where appropriate. For example, I asked interviewees general questions about their political goals, their resulting needs to reach those goals, and their go-to sources to fulfil these needs. I subsequently asked general questions about the occurrence of any contacts with sister parties and inquired into the general 'why' and added value of these contacts. Only then I asked about the resource dependencies identified in the theoretical framework more specifically.

Following this strategy, I made several adjustments to my first theoretical understanding of the resource dependencies of national parties in the EU. I added some dependencies and specifications of dependencies that emerged from the interviews, including that of public legitimacy related to office-seeking at the national level. I specified other resource dependencies on the basis of the interview findings and subsequent further reading. For example, collective electoral positions and collective campaign strategies related to voteseeking at the EU level are specifications of an initial hunch about the importance of collective electoral resources. I also maintained some of the initial resource dependencies. These include political expertise and subject-matter expertise, both of which are related to seeking policy success nationally.

Finally, I maintained two resource dependencies in the theoretical framework that were not found to be relevant as drivers of the transnational activities within the cases explored. This concerns procedural expertise related to policy-seeking at the national level and collective access to parliamentary and party resources related to office-seeking at the European level. Procedural expertise may be important to political parties from less well-endowed national parliaments, as well as in the context of policy proposals that parliaments scrutinise under the EWS (e.g. Cooper, 2015). Collective access to parliamentary and party resources may be relevant to newly established parties (e.g. McDonnell \& Werner, 2018; Startin \& Brack, 2016). For the sake of the comprehensiveness of the framework, I maintained these resource dependencies. Nevertheless, I did not further explore them within the research project.

\section{Operationalising system-level factors that condition transnational party activities}

To operationalise the system-level factors that are theoretically expected to condition transnational party activities - as presented in table 9 of chapter 3 - I adopt a dual approach.

On the one hand, I rely on descriptive statistics from various databases and sources to indicate the differences between the SPD, Greens, and the Left with regard to most of 
the system-level conditions. I draw on data from the Chapel Hill Expert Survey (CHES) about party positioning on ideology and particular policy areas (Bakker et al., 2015), on the ParlGov database about election results and cabinets (Döring \& Manow, 2018), and on the financial accounts of the German parties about the annual income and spending (archive of the Bundestag).

On the other hand, I rely on the perception of interviewees to interpret or further unravel several of the system-level conditions. This is highly important, because the experiences of practitioners may not always reflect 'factual' circumstances and abstract data cannot always manifest the impressions of practitioners (e.g. Luker, 2008, p. 113124). In this respect, some of the conditions are straightforward, such as whether a party is in opposition or in government. Other conditions, however, can be perceived differently by the actors within political parties. For example, data may suggest that certain ideological differences between sister parties are small, but party elites may experience them as insurmountable if differences concern highly salient issues.

Thus, the descriptive statistics primarily serve as background knowledge and the discussion of the findings is mainly based on the interviews and other qualitative sources. In chapters 5 and 6 respectively, I thus discuss quantitative data that relates to the two dossiers of EUNAVFOR Med and elections prior to discussing qualitative findings.

\section{3 | Case selection}

To explore the phenomenon of transnational party activities in the EU, it is crucial to acquire rich insights into the behaviour, motives and environment of relevant actors. Because case studies allow for such contextual richness, they are particularly suitable for exploratory research (see e.g. George \& Bennett, 2004). In this section, I first provide background information about the three left-wing German parties under scrutiny. I then discuss why these parties are important cases to understand transnational party activities. I also provide data about the expected variation between the parties in relation to the theoretical expectations about system-level conditions on transnational party activities. Finally, I introduce the two dossiers to observe actual practices of transnational party activities, namely EUNAVFOR Med and national and European elections. In so doing, I also provide some first background information about these dossiers.

\section{Background information about the SPD, the Left and the Greens}

The empirical study explores the transnational party activities of the three political parties on the left of the political spectrum with seats in the eighteenth (2013-2017) German Bundestag, namely the Sozialdemokratische Partei Deutschlands (SPD), Die Linke and Bündnis 90/Die Grünen. To stay close to how the parties understand themselves, I use the English translations of party names or the abbreviations that the parties themselves usually employ (Aylott, Blomgren \& Bergman, 2013, p. 24). I thus refer to the SPD, the Left and the Greens. 
The SPD, which translates to Social Democratic Party of Germany, is a social democratic party. The party was established in 1875 and has its roots in the labour movements of the nineteenth century. After the Second World War, the SPD emerged as one of the two major parties in the German political system, next to the CDU. It occupied the position of senior government party from 1969 to 1974 and from 1998 to 2005.

Like other social democratic parties in Europe, the SPD saw a programmatic shift towards more right-wing economic and social policies over time. In the 1990s, the party adopted a neo-liberal agenda, which it implemented under the Chancellorship of Gerhard Schröder (1998-2005). During Schröder's second term, the SPD's Agenda 2010 on labour market and welfare reforms ultimately "inflamed relations" with the labour unions and led to major internal divisions (Lavelle, 2008, p. 16; see also Braunthal, 2003). Since then, the party has seen a strong downward trend in electoral support. Programmatically, the SPD moved towards more left-wing economic and social policies in the aftermath of the financial crisis of the late 2000s (Bremer, 2017, p. 4).

Die Linke, literally the Left, is a party on the socialist, far-left side of the German political spectrum. The party was founded in 2007, after a merger between the Party of Democratic Socialism (Partei des Demokratischen Sozialismus, PDS) and the Electoral Alternative for Labour and Social Justice (Arbeit und soziale Gerechtigkeit - Die Wablalternative, WASG). The PDS had been represented in the Bundestag since 1990, as the legal successor of the East-German Communist party, the Socialist Unity Party of Germany (Sozialistische Einheitspartei Deutschlands). The WASG was a protest movement that split from the SPD in 2004 in response to Schröder's Agenda 2010 (about the merger, see e.g. Hough, Koss \& Olsen, 2007, p. 134-152).

The PDS initially emerged as a 'regional' party, as it represented the interests of citizens from the former German Democratic Republic in Eastern Germany (see e.g. Segert, 2002). Particularly after the merger with the WASG, however, the party developed a stronger profile as a national party to the left of the SPD (see e.g. Hough \& Keith, 2019). Not least given the origins of the Left both in Eastern Germany and in the protest movement against the SPD, the party is characterised by major internal ideological conflicts. Overall, however, the party "has developed a policy profile centring on issues of social justice, pacifism and a malleable form of protest against the way German politics works" (Hough \& Keith 2019, p. 131).

Finally, Bündnis 90/Die Grünen, literally Alliance 90/The Greens, is a Green party that is likewise the result of a merger between two parties. In West Germany, Die Grünen was founded in 1980 as "the party-organisational follow-up" to the social movements of the early 1970s (Bukow, 2016, p. 112). The party then entered the Bundestag in 1983. Ten years later, the party merged with the East German Alliance 90 - an alliance of citizens movements that emerged during the Peaceful Revolution of 1989-1990 (about the merger, see Poguntke, 1998). 
Much like the Left, the Greens were at first a party at the fringes of the German political system. However, over the course of the 1990s, the party "move[d] from being principally a party of opposition to a party of government" (Hough et al., 2007, p. 66). It has long faced internal disagreements between more leftist factions, the so-called Fundis, and more pragmatic factions, the Realos. Generally, the Greens have moved towards the centre-left of the political spectrum over time. Their programme combines an emphasis on environmental protection with progressive policies on financial and economic sustainability, and social justice (Bukow, 2016, p. 125-128).

\section{The SPD, the Left and the Greens as empirically rich and substantively important cases}

The 'typical' question of social scientists would then concern what sort or type of case transnational party activities by the three German parties is, as opposed or in comparison to other, potential cases (see e.g. Gerring 2006; Levy, 2008; Seawright \& Gerring, 2008). That is, the primary aim of most case selection practices is to reach maximum generalisability. Cases are selected in such a way that they can tell the researcher something about the entire class of cases. This procedure requires substantial prior knowledge not only about theory, but also about the range of possible cases and the qualities of these cases. It is on the basis of clear-cut hypotheses and prior knowledge about the population of cases that one can distinguish between a more or less likely case.

In the present research design, however, it is difficult to provide an unambiguous answer to these questions. Indeed, because there is so little previous research specifically on transnational party activities by national political parties, it is awkward to classify the three German parties as a particular type of case (see also Miklin, 2013, p. 28).

On the one hand, the three parties could be considered a most likely case for national parties engaging in transnational party activities. With 630 members, the Bundestag is one of the largest parliaments in the EU.12 It is known as a 'working parliament', in which most MPs are experts on particular policy areas, efficiency-oriented, and focused on participation in law making (see e.g. Schüttemeyer, 2009). The Bundestag and the German political parties are very well-endowed in comparison to parties from lessendowed parliaments, so that the parties have the funds, staff, and infrastructure to engage in transnational activities. Transnational party cooperation also fits well with the political tradition and culture of the German parties. All three parties have an established tradition of engaging in transnational party contacts (see e.g. Chiochetti, 2017, p. 82; Dietz, 1997; Drögemöller, 2005) Germany also traditionally has a strong multilateral and 'Europeanist' political culture, particularly in the area of security and defence (e.g. Chappell, 2016).

On the other hand, the three parties could be considered an unlikely case to find that transnational party activities take place. This is precisely because the German 
Bundestag is a relatively strong parliament compared to other national parliaments in the EU, both in terms of institutional capacity and in terms of powers to scrutinise the national government in EU affairs (see Hefftler, Neuhold, Rozenberg \& Smith, 2015). The parliament also has far-reaching information rights and systems (Höing, 2015).13 The German political parties may thus simply obtain the resources they need from the government or through in-house staff. They may therefore face a lower need to engage in transnational activities to obtain resources from outside. Given these considerations, parties in a parliament with weak institutional capacity and weak constitutional powers in EU affairs would constitute a more likely case, such as the Belgian parties.

Is it problematic that the three cases cannot easily be classified as more or less likely cases? I find that it is not. As discussed in section 4.1, the primary concern of the exploratory inquiry is not with generalising theoretical propositions to a wide set of cases, but with further developing the plausibility of a framework to understand transnational party activities. A case that is most suitable for the purpose of generalisation may not be most suitable for the purpose of exploration.

The three German parties under scrutiny are well qualified for the exploratory endeavour. Most importantly, the transnational party activities of the SPD, the Left, and the Greens are substantively important cases (Mahoney \& Goertz, 2006, p. 242-243). Three reasons for this stand out. First, the SPD, the Left and the Greens have long dominated transnational politics in the European Parliament, both numerically, organisationally, financially, and in terms of their commitment to European integration (Pridham \& Pridham, 1981, p. 155). Second, the three parties are all "heavily influential" within their respective Europarties (Hanley, 2008, p. 206; see also Klüver \& Rodon, 2012). They occupy important positions within their Europarties, including the positions of Secretary General of the PES, President of the PEL, and Co-Chair of the EGP respectively. Historically, the three parties have also been highly influential in informal transnational party networks outside the Europarties. They maintain very strong international networks, also through their political foundations (see e.g. Chiochetti, 2017, p. 82; Salm, 2016). And third, given the weight of Germany in terms its demography, politics and economy, the parties have "an objectively superior importance" for national parties in other EU member states (Chiochetti, 2017, p. 8).

Arguably, substantively important cases are "of special normative interest because of a past or current major role in domestic or international politics" (Mahoney \& Goertz, 2006, p. 242). For a theoretical approach to be persuasive, it is essential that it provides a convincing understanding of such substantively important cases. As Mahoney and Goertz (2006) write, "qualitative researchers almost instinctively understand the requirement of getting the 'big' cases right and worry when it is not met" (p. 243). As such, the three

13 These rights are established in the Constitution, the Act on Cooperation between the Federal Government and the German Bundestag in Matters concerning the European Union (EUZBBG) and the Responsibility for Integration Act (IntVG). 
German parties provide an excellent case. Moreover, the contextual factors just mentioned also make the German parties an empirically rich case. This empirical richness is a feature of interesting case studies that is often stressed by interpretivists, as it allows for the rich description that is necessary to understand the "whys' and 'hows" of behaviour (Schwartz-Shea \& Yanow, 2012, p. 48).

\section{$V$ ariation between the Greens, the Left and the SPD with regard to the theoretical expectations}

The similarity of the parties allows me to manage many potentially intervening factors. The parties operate within the same national parliament and within the context of a shared national political history and culture, and they are geographically located in the same capital city. They are also all positioned at the same, centre-left end of the political spectrum. My cases are thus "closely related to each other" (Gerring, 2007, p. 91), which arguably "serves to eliminate a lot of potentially confounding background variables" (Aylott et al., 2013, p. 22).

At the same time, the Greens, the Left and the SPD show variation on the three sets of sets of system-level factors that condition transnational party activities in the EU, as outlined in chapter 3 (see table 9). This allows me to avoid the potential problems associated with researching causality in a design without such variation (Haverland, 2006) and to explore the plausibility of my theoretical arguments. Most importantly, the parties differ with respect to being in and out of government, with respect to their in-house resources and the presence of successful sister parties, and with respect to the ideological coherence of their party families.

Table 11 | Opposition/government status of parties in the Bundestag, 1990-2017

\begin{tabular}{|c|c|c|c|c|}
\hline Years & Cabinet & $\begin{array}{l}\text { Senior } \\
\text { coalition party }\end{array}$ & $\begin{array}{l}\text { Junior coalition } \\
\text { party }\end{array}$ & $\begin{array}{l}\text { Opposition (in order of } \\
\text { size in parliament) }\end{array}$ \\
\hline 1991-1994 & Kohl IV & $\mathrm{CDU} / \mathrm{CSU}$ & FDP & SPD, the Left, Greens \\
\hline 1994-1998 & Kohl V & $\mathrm{CDU} / \mathrm{CSU}$ & FDP & SPD, Greens, the Left \\
\hline $1998-2002$ & Schröder I & SPD & Greens & CDU/CSU, FDP, the Left \\
\hline $2002-2005$ & $\begin{array}{l}\text { Schröder } \\
\text { II }\end{array}$ & SPD & Greens & CDU/CSU, FDP, the Left \\
\hline 2005-2009 & Merkel I & $\mathrm{CDU} / \mathrm{CSU}$ & SPD & FDP, the Left, Greens \\
\hline $2009-2013$ & Merkel II & $\mathrm{CDU} / \mathrm{CSU}$ & FDP & SPD, the Left, Greens \\
\hline 2013-2017 & Merkel III & $\mathrm{CDU} / \mathrm{CSU}$ & SPD & the Left, Greens \\
\hline 2018- & Merkel IV & $\mathrm{CDU} / \mathrm{CSU}$ & SPD & AfD, FDP, Greens, the Left \\
\hline
\end{tabular}

Data from ParlGov database (Döring \& Manow, 2018). The row with the years 2013-2017 (eighteenth Bundestag) is marked in grey as this is the focus of this dissertation.

Note: between September 2017 and March 2018, there was a caretaker government of the CDU/CSU and SPD.

First, in the eighteenth Bundestag (2013-2017), the SPD was the junior coalition party in a government with the CDU/CSU, while the Greens and the Left were in opposition. 
Historically, the Left has never been part of the federal government, whereas the Greens were the junior coalition partner of the SPD during the years 1998 to 2005. Table 11 provides an overview of the minority or majority status of the German parties since 1990.

Of the three parties, the SPD has had the highest seat shares in the Bundestag, although the party has seen a decline over the last decade. The Greens have held around $10 \%$ of the seats since the turn of the century and so has the Left since its "breakthrough" in 2005 (Hanley, 2008, p. 149). Figure 4 displays the seat shares in the Bundestag since the first federal elections after Germany's unification in 1990.

Figure 4 | Seat shares in the Bundestag, 1990-2017

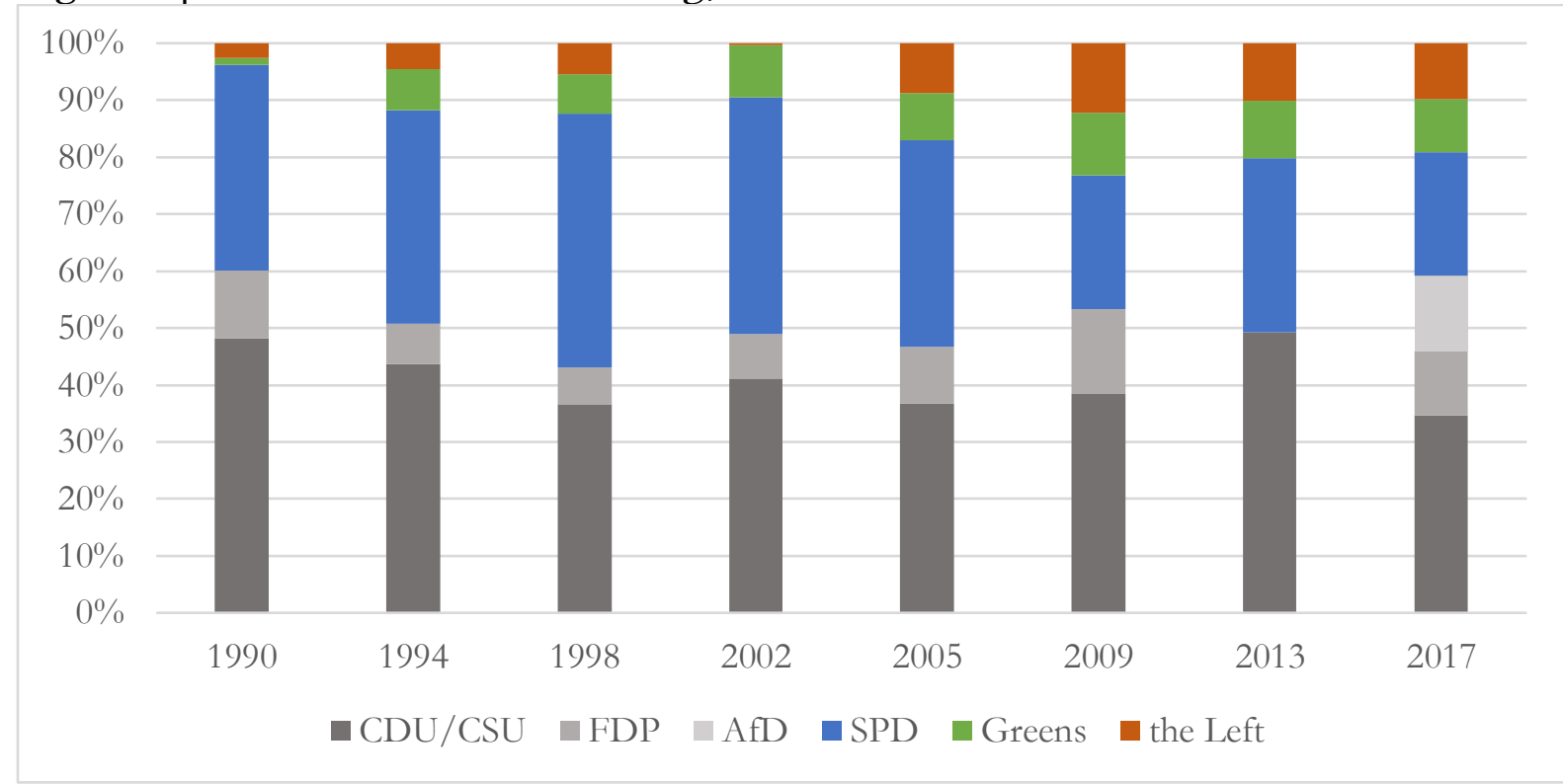

Data from ParlGov database (Döring \& Manow, 2018).

Second, in the various member states of the European Union, considerably more sister parties of the SPD occupied government or parliamentary office than did sister parties of the Left and the Greens. From 2013 to 2019, there were socialist heads of government in Austria, Belgium, the Czech Republic, Denmark, Spain, France, Italy, Lithuania, Malta, Portugal, Romania, Slovakia, and Sweden. Parties from the socialist party family were also junior coalition partner in Estonia, Finland, Greece, Ireland, Luxembourg, the Netherlands, and Slovenia. By contrast, there were only two heads of government in the radical left party family, namely in Cyprus (from 2008 to 2013) and Greece (from 2015 to 2019). In Finland, the Left Alliance was part of the coalition government from 2011 to 2014. There were no heads of government within the green party family in the EU, although Latvia had a prime minister from a localist party in a parliamentary alliance with the Latvian green party. Green parties were, however, part of coalition governments in Denmark, Finland, France, Luxembourg, Latvia, and Sweden.14 
Moreover, given the larger size of the SPD, it is not suprising that the party also has considerably more in-house resources than the smaller Greens and the Left, both in parliament and in central office (Hefftler, 2015, p. 8; Schüttemeyer, 2009, p. 8). Figure 5 displays the annual income and equity of the three parties. It clearly illustrates that the SPD is much richer than the Greens and the Left, while the Greens are somewhat richer than the Left.

Figure 5 | Annual income and equity of the SPD, Greens and the Left, 2002-2017

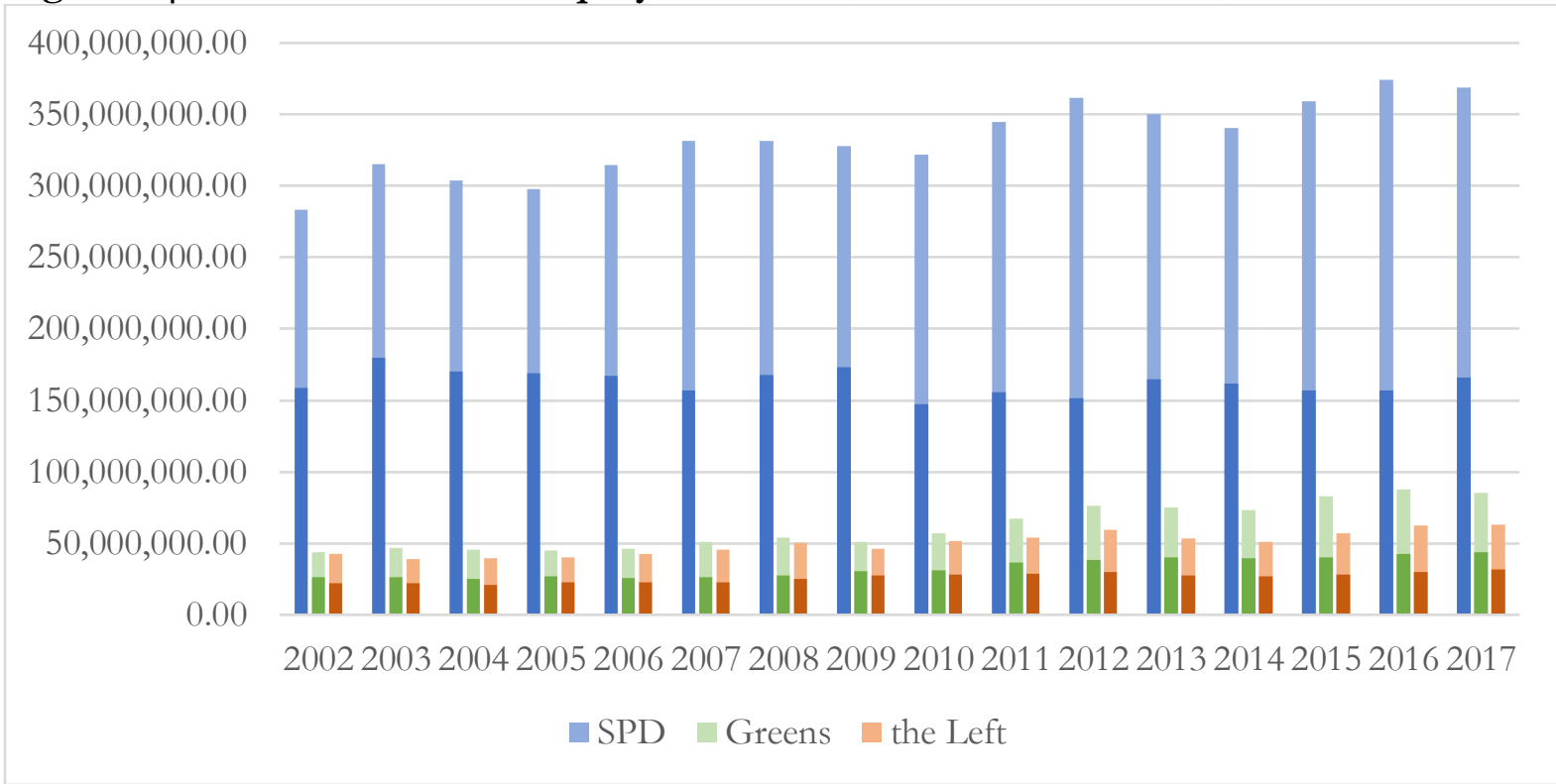

Data from the statements of accounts 'Rechenschaftsberichten', available via http://pdok.bundestag.de. The darker parts of the columns display annual income, while the lighter parts display equity.

Note: The graph does not display the annual income and equity of the WASG, which existed as an official separate party with its own financial resources in 2006 and 2007.

Third, data from the 2014 Chapel Hill Expert Survey (CHES) (Polk et al., 2017) and the 1999-2014 CHES trend file (Bakker et al., 2015) suggests that the socialist party family is more ideologically coherent than the green and radical left families (see also Klüver \& Rodon, 2012).15 Figure 6 shows that most parties in the socialist and radical left party

15 The 2014 CHES dataset provides information on the positioning of political parties in all EU member states. It is based on average expert judgement scored, administered through a survey. The codebook explains that the question on EU integration (EU_POSITION) is "overall orientation of the party leadership towards European integration in 2014". The question on left/right general (LRGEN) is "position of the party in 2014 in terms of its overall ideological stance". I included the Croatian parties in the figures, even though Croatia was not an EU member at the time the survey was conducted. I excluded Switzerland and Norway. I used data from the 1999-2014 CHES trend file that classifies the parties into party families. This classification is based on Hix and Lord (1997), and, for the Central and Eastern European parties, on Derksen classification, "triangulated by membership or affiliation with international and EU party associations, and self-identification" (codebook, p. 14). I cross-checked the party family classification with data from the Comparative Manifesto Project. To improve the CHES dataset, I made four changes after manually checking Europarty and EP party group party affiliation of parties categorised 
families are economically more left-wing than most parties in the green party family. Conversely, most green parties are more progressive than most socialist and radical left parties. Several distributions are skewed, however. Most strikingly, the positions of all three party families are skewed towards the TAN dimension. Moreover, the economic left/right position of the green family is skewed towards the left, which is mainly due to the positions of the Irish and Cypriot green parties, and the Dutch Party for the Animals.

The box plots in figure 6 suggest that socialist parties are more clustered around the same general left/right position than green and radical left parties. The range of positions is smaller, and the population standard deviation is also lower (0.568) than those of the green (1.334) and radical left (0.833) party families. Neither family, however, shows coherence on the GAL/TAN dimension.

\section{Figure 6 | Distribution of general ideological positions of the Green, Radical left and Socialist EU party families, 2014}

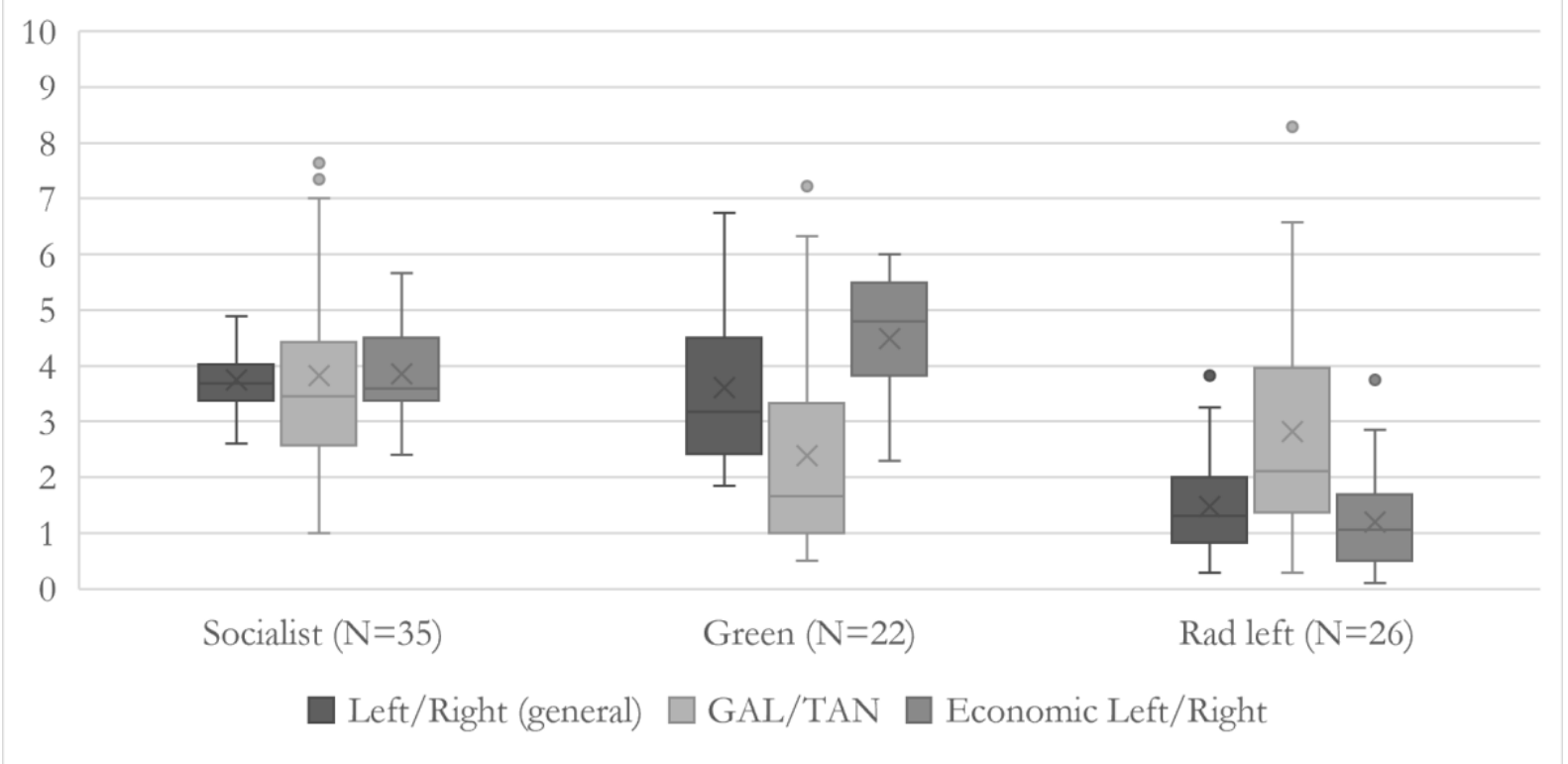

Source: 2014 CHES (Polk et al., 2017) and 1999-2014 CHES trend file (Bakeker et al., 2015).

Note: The scales left/right (general) and economic left/ right run from 0 (extreme left) to 10 (extreme right). The scale GAL/TAN runs from 0 (Libertarian/Postmaterialist) to 10 (Traditional/Authoritarian). None of the indicated outliers are major parties in the European Parliament or parties from large EU member states.

Finally, figure 7 shows that the socialist parties in the EU are generally closer to the general left/right and EU integration stance of the SPD than the green parties and the radical left parties in the EU are to the Greens and Left respectively. 
Figure 7 | Distribution of positions towards European integration and left/right positions of the Socialist, Green and Left EU party families, 2014

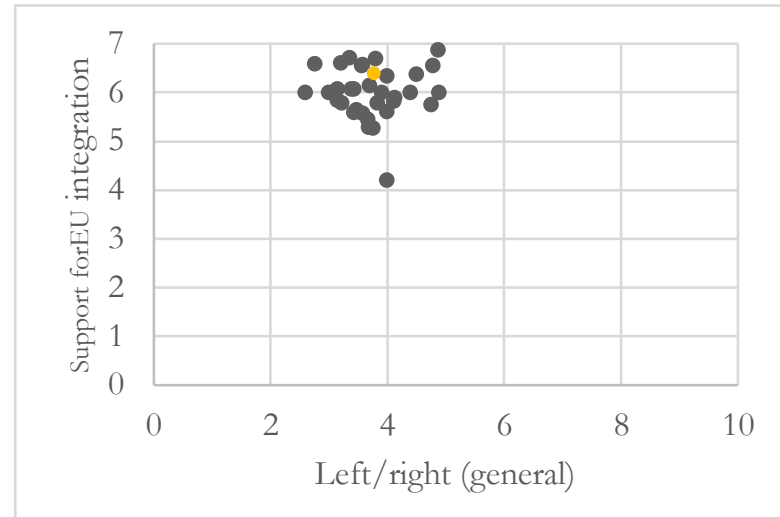

Socialist family $(\mathrm{N}=34$, missing data Maltese PL)

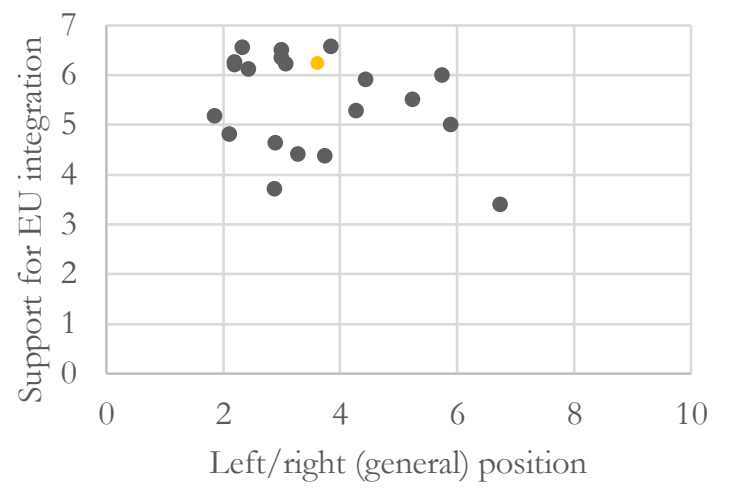

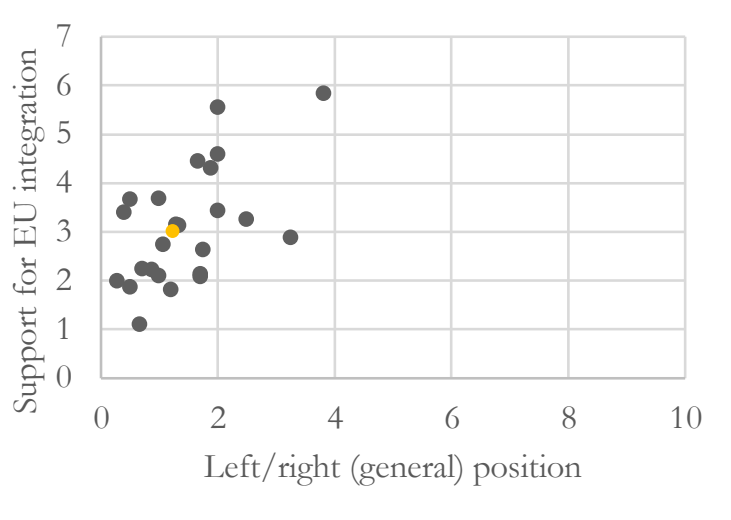

Radical left family $(\mathrm{N}=26)$
Source: 2014 CHES (Polk et al., 2017) and 1999. 2014 CHES trend file (Bakeker et al., 2015). Note: The scale European integration runs from 0 (strongly opposed) to 7 (strongly in favour). The scale left/ right runs from 0 (extreme left) to 10 (extreme right). The German parties are marked with a yellow dot.

Green family (N=21, missing data German Die Tier)

The "building blocks": EUNAVFOR Med and national and European elections as dossiers to study transnational party activities

To study transnational party activities in response to resource dependencies, it is crucial to observe the actual vote, office, and policy-seeking behaviour of political parties. I thus need to explore the transnational party activities of the SPD, the Left and the Greens within the context of particular events or 'dossiers'. The two dossiers that are explored in this dissertation are the EU military operation against human trafficking in the Mediterranean Sea, called European Naval Force Mediterranean (EUNAVFOR Med), and national and European election campaigns.

These two dossiers are the "building blocks" for the overall resource-dependence perspective on transnational party activities in the EU (George \& Bennett, 2004, p. 76, 78). This means that the dossiers cover different aspects within the overall theoretical framework.16 That is, I explore transnational party activities in the context of policy-seeking

${ }_{16}$ Some authors use the term 'case-within-a-case' for a subcase that is part of the larger case of interest (e.g. Gondo, Amis \& Vardaman, 2012). The two dossiers in the current research design are, however, not just 'cases within cases'. Rather, they cover different aspects of the overall theoretical framework. The term "building block" of George and Bennett (2004) more explicitly captures that characteristic. 
behaviour through the dossier of EUNAVFOR Med. I explore transnational party activities in the context of vote and office-seeking behaviour through the dossier of national and European election campaigns. Table 12 shows how these case studies cover the various resource dependencies set out the theoretical framework of chapter 3.

EUNAVFOR Med is an EU military operation that was decided upon within the realm of the CSDP. It has been politically and publicly highly contested, both in Germany and in other EU member states (see e.g. House of Lords, 2017). Such contestation is most importantly due to the nature of the operation as a military response to the death of many thousands of people in the Mediterranean Sea, which became known as the 'refugee' or 'migration crisis' in early 2015. Ever since the launch of EUNAVFOR Med in spring 2015, there have been controversies around the strategy and mandate of the operation (e.g. Faleg \& Blockmans, 2015). In particular, EUNAVFOR Med has arguably prioritised border control and actions against smugglers over operations to rescue people at sea (see e.g. Cusumano, 2018). 17

Germany has been a central actor both during the phase in which EUNAVFOR Med was designed and during the actual execution of the operation. After initial hesitance, the German government ultimately put itself in the lead of plans to launch a military operation in the Mediterranean. This can best be understood as a response to criticisms that it had been too lenient in the face of the 'refugee crisis' (Rettman, 2015; Johansen, 2017, p. 520; Nováky, 2018, p. 202; see further in chapter 5). The topic of illegal migration has been high on the German political agenda ever since, not least given the growing popularity of the Alternative for Germany (Alternative für Deutschland, AfD). EUNAVFOR Med has also been contested in the Bundestag, as the opposition parties the Greens and the Left voted against a German contribution to the operation.

Given the contested nature of EUNAVFOR Med and the centrality of Germany in the operation, it is reasonable to expect that the German parties have been highly involved in the scrutiny and control of EUNAVFOR Med. Indeed, a study by Jäger, Oppermann, Höse and Viehrig shows that deployments of the German army, the Bundeswehr, have been one the most important foreign affairs issues to German MPs (2009, p. 427-428; see also Huff, 2015, p. 409). Herbel (2017) finds that the political importance of a CFSP issue has a "powerful positive effect on the likelihood of scrutiny" (p. 717). Huff (2015) likewise argues that the degree of political salience of an issue can explain the willingness of MPs to "invest time and resources in CFSP [and CSDP] scrutiny" (p. 408). It is likely that the domestic salience of an issue is also important to explain the willingness of national parties to engage in contacts within the network of the party family (Hix \& Lord, 1997, p. 73-74).

17 Note that EUNAVFOR Med is referred to as 'Operation Sophia' in many public or political debates. This is because the Council officially renamed the operation in October 2015 after the birth of a child on one of the ships partaking in the operation. However, I here refer to the operation as EUNAVFOR Med, because several political parties contest the name Operation Sophia. 
Table 12 Case studies in relation to the resource dependencies of the theoretical framework

\begin{tabular}{|c|c|c|c|}
\hline $\begin{array}{l}\text { Party goals } \\
\text { considered }\end{array}$ & Dossier & Details of the case study & Resource dependencies explored* \\
\hline $\begin{array}{l}\text { Electoral success } \\
\text { (vote-seeking) }\end{array}$ & $\begin{array}{l}\text { Transnational party } \\
\text { activities with a view to } \\
\text { national and European } \\
\text { elections }\end{array}$ & $\begin{array}{l}\text { Activities of the SPD, Greens and the Left in } \\
\text { view of the } 2014 \text { and } 2019 \text { European elections, } \\
\text { and the } 2013 \text { and } 2017 \text { Federal elections }\end{array}$ & $\begin{array}{l}\text { - National level: electoral positions, campaign } \\
\text { expertise } \\
\text { - European level: collective electoral } \\
\text { positions, collective campaign strategies }\end{array}$ \\
\hline $\begin{array}{l}\text { Benefits of office } \\
\text { (office-seeking) }\end{array}$ & $\begin{array}{l}\text { Transnational party } \\
\text { activities with a view to } \\
\text { national and European } \\
\text { elections }\end{array}$ & $\begin{array}{l}\text { Activities of the SPD, Greens and the Left in } \\
\text { view of the } 2014 \text { and } 2019 \text { European elections, } \\
\text { and the } 2013 \text { and } 2017 \text { Federal elections }\end{array}$ & - National level: public legitimacy \\
\hline $\begin{array}{l}\text { Policy success } \\
\text { (policy-seeking) }\end{array}$ & $\begin{array}{l}\text { Transnational party } \\
\text { cooperation on the } \\
\text { European Naval Force } \\
\text { Mediterranean }\end{array}$ & $\begin{array}{l}\text { Activities of the SPD, Greens and the Left in } \\
\text { view of EUNAVFOR Med between spring } \\
2015 \text { and autumn } 2018\end{array}$ & $\begin{array}{l}\text { - National level: political expertise, subject- } \\
\text { matter expertise } \\
\text { - European level: collective political strategies, } \\
\text { collective political positions }\end{array}$ \\
\hline
\end{tabular}


Moreover, there is special relevance to observing the transnational activities of national parties in the domain of CFSP/CSDP, because the democratic scrutiny of the CFSP/CSDP as such is a contested issue. Contrary to most other policy areas, decision making in the CSDP is inter-governmental and the powers of the EP vis-à-vis the Council of Ministers are limited. As discussed in chapter 1, platforms for inter-parliamentary cooperation have in particular been established in those policy areas governed by intergovernmental decision making. The inter-parliamentary conference for the CFSP/CSDP was indeed the first 'specialised' conference, which reflects concerns about democratic scrutiny of this area (Herranz-Surrallés, 2014).

That is, foreign and security affairs have long been considered a domain of decision making that should be kept in the hands of governments. But the debacles of the Afghanistan and Iraq wars in the early 2000s led to new concern with the democratic involvement of parliaments in European foreign and security affairs (see e.g. Dieterich, Hummel \& Marschall, 2014; Fonck, Haesebrouck \& Reykers, 2019; Mello \& Peters, 2018; Raunio \& Wagner, 2017; Wagner, Herranz-Surrallés, Kaarbo \& Ostermann, 2017). This debate about parliamentary control over troop deployments is of particular relevance in the German context. As Peters (2018) writes, "German history has produced a unique and complicated constitutional regime on the deployment of the German military abroad" (p. 246). Indeed, the German Bundestag has voted on more troop deployments than any other parliament in the world (Wagner, 2017).

The focus of the dossier on national and European election campaigns is on the 2013 and 2017 national elections (Bundestagswabl) and the 2014 and 2019 European elections (Europawab). The Bundestagswahl is the most important national election in Germany. It does not only determine the composition of the Bundestag, but also which party can form a government and deliver the Chancellor.18 Both the 2013 and 2017 national elections were regular elections, which means that parties had time to prepare their campaigns (see further in chapter 6).

The 2013 elections were a crucial test to the SPD in particular. The 2009 federal elections had been "boring" yet "extreme" (Rattinger, Roßteutscher, Schmitt-Beck \& Weßels 2011). Most importantly, the SPD had obtained the lowest number of votes and seats in its history. It returned to the opposition of the seventeenth Bundestag from 2009 to 2013, using the time to "start a process of consolidation and programmatic renewal" (Faas, 2015, p. 239). During the eighteenth legislative period, the 'refugee crisis' became a critical issue in the German political debate. The AfD benefitted from polarisation around questions about migration and integration (Hansen \& Olsen, 2018). In the 2017 elections, this presented an important challenge to the three left-wing parties, not least because German election campaigns are traditionally run on the basis of socio-economic rather than socio-cultural positions (Franzmann, Giebler \& Poguntke, 2019).

18 The other chamber of the German parliament, the Bundesrat, is not directly elected, but composed of delegations from the German states. 
The 2014 and 2019 Europawablen gained significance in the context of the major changes in Germany's national party system that resulted from the 2013 and 2017 Bundestagswablen (e.g. Möller, 2019; Poguntke, 2019). In addition, it is reasonable to expect more transnational party activities by the three German parties in light of the introduction of the Spitzenkandidaten system. The 2014 elections of the European Parliament for the first time saw campaigns by lead candidates for the office of Commission President (see e.g. Christiansen, 2016). Both the SPD and the Greens supported politicians from within their own ranks to run as Spitzenkandidat for their Europarty: the SPD with Martin Schulz in 2014, and the Greens with Ska Keller in 2014 and 2019.

The time period of both dossiers is around and during the eighteenth Bundestag, which was in office from October 2013 to October 2017. The time frame of the study on EUNAVFOR Med is from the start of talks about the launch of a military operation in spring 2015 up to the end of the eighteenth Bundestag. When interviewees shared information about transnational activities during the subsequent, nineteenth Bundestag, I have included this to further support my findings. Studying transnational activities both at the start of and during the military operation allows for considering different dynamics. The study of two national and two European elections likewise allows for considering a broader set of dynamics. Moreover, because several interviewees had already been active in party campaigning well before 2013, I also obtained insights into transnational exchange regarding election campaigns from earlier elections. I have included such insights to further corroborate evidence. The similar time period of both dossiers allows for a comparison of the findings.

\subsection{Data analysis and data collection}

Where does one find data about transnational party activities? And how can such data best be analysed? In the current section, I first introduce the type of comparative analysis that the dissertation employs. I subsequently discuss the use of semi-structured interviews with political elites and the challenges that come with that. Finally, I discuss the use of other primary sources to triangulate interview findings.

\section{The 'structured, focused comparison'}

The discussion of my case selection already reflects that I explore the transnational party activities of the SPD, the Left, and the Greens through a comparative analysis. Overall, the research design follows the strategy of a "structured, focused comparison" (George \& Bennett, 2004, p. 67ff). As George \& Bennett explain:

This method is 'structured' in that the researcher writes general questions that reflect the research objective and that these questions are asked of each case under study to guide and standardize data collection, thereby making systematic comparison and cumulation of the findings of the cases possible. 
The method is 'focused' in that it deals only with certain aspects of the historical cases examined (p. 67).

The 'focus' of the comparison is primarily provided by the theoretical lens (p. 70). In this dissertation, this is the resource-dependence perspective on transnational party activities in the EU. This theoretical lens also provides the 'structure' for the comparison. That is, I systematically compare the transnational party activities of the SPD, the Left, and the Greens on the basis of the resource dependencies identified to drive transnational party activities. In other words, the description of transnational party activities is "theoreticallyfocused" (p. 94). Given the variation between the three parties described in section 4.3 above, this allows me to draw conclusions about the plausibility of the theoretical expectations concerning the system-level factors that condition transnational party activities.

I ultimately compare the variation between the transnational party activities of the three parties in terms of the importance that interviewees generally attributed to transnational activities with a view to a particular resource dependency. For the sake of parsimony, I use the categorisation 'no importance', 'limited importance', 'some importance', and 'substantial importance' (on describing variance in comparative case studies, see George \& Bennett, 2004, p. 84ff). Table 13 below spells out these categories and the criteria for operationalisation. Clearly, given the nature of the data, it is not possible to formulate strict cut-off points for "scoring" transnational party activities in one category or another (2004, p. 90). Table 13, however, presents the overall frame of reference for describing the importance of transnational party activities.

Table 13 | Frame of reference for the 'scoring' of transnational party activities

\begin{tabular}{ll}
\hline Category & Description \\
\hline No importance & $\begin{array}{l}\text { Interviewees did not provide examples of actual transnational party } \\
\text { activities and found such activities irrelevant to their work. }\end{array}$ \\
\hline $\begin{array}{l}\text { Limited } \\
\text { importance }\end{array}$ & $\begin{array}{l}\text { Interviewees recalled only anecdotal examples of actual transnational } \\
\text { party activities and believed these activities to be of limited relevance to } \\
\text { their work. }\end{array}$ \\
\hline Some importance & $\begin{array}{l}\text { Interviewees provided some examples of transnational party activities. } \\
\text { They believed that these were relevant to their work or of symbolic value. }\end{array}$ \\
& $\begin{array}{l}\text { The transnational activities were pursued mostly on an irregular basis. } \\
\text { Substantial }\end{array}$ \\
importance & $\begin{array}{l}\text { acterviewees provided various examples of actual transnational party } \\
\text { their work or stressed the symbolic value of transnational activities. The } \\
\text { transnational party activities were also systematically pursued. }\end{array}$ \\
\hline
\end{tabular}

While the primary strategy of analysis is thus a comparison across the cases of the SPD, the Left, and the Greens, the analysis also has two important within-case aspects. 
First, I am interested not only in the differences between the transnational party activities of the three parties, but also in the particularities of each case. Therefore, I maintain an openness to insights from within these cases. This also suits the exploratory strategy of the research design. Such insights for example, concern why a party especially sought after a certain type of expertise or how a party managed expectations about particular norms of appropriate behaviour in transnational party activities.

Second, the analysis of the two dossiers of EUNAVFOR Med and election campaigns is primarily within-case. Most importantly, this means that I explore the transnational activities of the three political parties within the context of the dossiers at hand. In other words, I both describe and interpret transnational party activities in view of the context in which they took place (Ponterotto, 2006, p. 543). This strategy allows me to 'match' the theoretical expectations about system-level conditions to descriptions of broader political dynamics and actual transnational party activities (see e.g. Mahoney, 2000, p. 409ff). It also allows me to draw conclusions about what resource dependencies are the main 'drivers' for transnational party activities in the context of the characteristics of the dossiers at hand.

In chapter 7, I subsequently synthesise the findings and draw a comparison across the two dossiers. I evaluate the plausibility of the resource-dependence perspective on transnational party activities in the EU in view of the available data. I also evaluate if the perspective can be supported by existing studies (George \& Bennett, 2004, p. 91). Although there is a small temporal aspect to my research design, analysing changes over time is not my primary objective. The study is therefore not "comparative-historical" (Gerring, 2004, p. 343). Table 14 summarises the strategy of analysis per chapter.

\section{Strategies and challenges of conducting elite interviews on transnational party activities}

To analyse transnational party activities of the SPD, Greens, and the Left on EUNAVFOR Med and national and European elections, I most importantly rely on forty semi-structured interviews. Table 15 presents the number of interviewees per dossier and case study. A complete overview of the affiliation of interviewees, and the place and date of interviews can be found in annex 1. Before discussing my data collection in more detail, however, two remarks about studying transnational party activities are in order.

First, transnational party activities are in practice often informal (see also Hefftler, 2015; Miklin, 2013; Salm, 2016). Even when contacts across national boundaries or between a national and European party take place in a more systematic manner, information is usually not made public or is only superficial. Scholars studying informal transnational party activities have previously mostly relied on archival material (e.g. Drögemoller, 2005; Salm, 2016) or combined archival research with interviews (e.g. Johansson, 2002a; Külahci, 2010). The drawback of this approach is that archival research is ill-suited to study transnational activities of parties that are recent at the moment of conducting the research. This may be problematic given fast-changing dynamics in national politics and European integration. 
Second, the topic of transnational party activities can be sensitive for political parties. That is, MPs or staff members may feel that they should engage in contacts with counterparts in sister parties, given their normative beliefs about the importance of such contacts. Yet in practice, they may not act transnationally in the face of more immediate concerns. Clearly, it is sensitive to talk about why one does not engage in something that one sees as normatively important. At the same time, also contacts that do take place may be sensitive, particularly when they involve attempts to influence the position of sister parties or to share politically sensitive information.

These two issues, the informality and sensitivity of transnational activities, have implications for my research design. For one, it was my initial ambition to also include the CDU in the study, along with the parliamentary alliance of the CDU/CSU. However, I faced difficulties in scheduling a sufficient number of interviews with its MPs or staff. Repeated requests were rejected either for the reason of lack of time, perceived lack of relevance, or perceived sensitivity. Therefore, I ultimately had to exclude the CDU/CSU. Clearly, this is to the detriment of the potential generalisability of my findings about the transnational activities of national parties. However, such generalisability was never the primary objective of my research. The advantage of dropping the CDU/CSU is that it leaves me with three cases that are more similar to each other (see section 4.3).

Moreover, I took into account the informality and potential sensitivity of transnational activities in approaching interviewees. Most importantly, I treated information that interviewees provided anonymously (see e.g. Lancaster, 2017). Given the political sensitivity and informality of the topic, I also do not use quotes from the interviews. I phrased my request for a research interview in broad terms, because I also wanted to talk to those actors who had not engaged in transnational party activities (on getting access to respondents, see e.g. Goldstein, 2002).

For the study on EUNAVFOR Med, I initially contacted all MPs who had been involved in the scrutiny of the operation. For the study on national and European elections, I retraced and initially contacted all party officials who had worked on election campaigns between 2013 and 2019. About half of my requests were rejected, usually for the reason of lack of time. By the end of each interview, I used the so-called 'snowballing technique', which involves asking interviewees whom they would recommend as interview respondent on the topic. To triangulate sources (Natow, 2019, p. 5-7), I talked to party elites at different levels in the party organisation. I also contacted party elites in other EU member states that were mentioned as contacts. However, interviewees often did not recall their names and the response rate to these requests was low.

Because I have not spoken to all MPs and staff members who may have possibly been involved in transnational party activities, I cannot be certain about the extent to which the SPD, the Greens and the Left have engaged in contacts with MPs, MEPs or staff members from sister parties elsewhere. The objective of this dissertation, however, is indeed not measure such an extent, but to identify what drives transnational party activities and under what conditions party engage them. Ultimately, for the purpose of the exploratory 
endeavour, the quality of interviews is more important than their quantity, or their representativeness of the whole 'population' of potential interviewees.

I initially recorded interviews, because of the benefits of having verbatim transcriptions (see e.g. Kvale \& Brinkmann, 2009, 180ff) and because recording allowed me to focus on the conversation. Several interviewees were, however, uncomfortable with the recorder (see also Peabody et al., 1990, p. 454). Indeed, there is disagreement about whether recording interviews is beneficial, and some authors argue that recording is to the detriment of establishing a comfortable atmosphere (see e.g. Harvey, 2011, p. 436-437). I hence took recourse to note taking. Note taking does not permit for a complete and exact transcript of the interview. Nevertheless, as Peabody et al. (1990) argue, "by jotting down key words and phrases of the respondent's answers [the researcher] can jog the memory, permitting the rest of what was said to come back later" (p. 454). I filled "gaps and phrases" in my written notes immediately after interviews and transcribed notes on the same day whenever possible (p. 454).

Finally, I conducted interviews in person whenever possible. This has the benefit of establishing a personal relationship with the interviewees and of being able to interpret non-verbal communication (see also Harvey, 2011, p. 435-436). Yet because politicians and their staff members are often highly pressed for time, I also conducted interviews via telephone and Skype to allow for more flexibility. A few respondents answered to written questions via e-mail or voice messages. It has previously been argued that telephone interviewees, and written responses in particular, are less detailed than face-to-face interviews (for a discussion, see Sturges \& Hanrahan, 2004). E-mail and voice-recorded responses to written questions were indeed considerably shorter, but telephone interviews were as long as face-to-face interviews. They additionally provided the benefit of "relative anonymity" to the interviewees (Sturges \& Hanrahan, 2004, p. 108-109).

\section{Documents to triangulate interview findings on transnational party activities}

In the context of the topic of the dissertation, it may be that interviewees exaggerated involvement in transnational party activities or, by contrast, did not share information about activities in the face of political sensitivity. More generally, as Natow (2019) points out, “elite interviews may be limited by elites' faulty memories, self-serving statements, misrepresentations, or elusiveness" (p. 2). I have therefore relied on various documents to triangulate interview findings. These documents included policy documents, news media, and internet-based data (p. 7).

Although the use of other documents can help the researcher to verify what interviewees say (Natow, 2019, p. 2), in practice, triangulation through multiple data sources and through multiple types of data is more about "justifying and underpinning knowledge by gaining additional knowledge" (Flick, 2004, p. 179). That is, documents are produced within a particular setting and these settings have their own - political - logic. Parliamentary speeches, for example, are heavily influenced by the speaker's awareness of 
the public stage and of the political processes preceding actual decision making. I thus mostly relied on documents as additional sources of information.

For the study on EUNAVFOR Med, I most importantly retrieved all relevant legislative records of the German Bundestag through the Documentation and Information system of the parliament (Dokumentations- und Informationssystem, DIP). This included parliamentary debates, motions (Entschliessungsantrag), answers to parliamentary questions (Kleine Anfragen)19, proposed resolutions (Beschlussempfehlung), and requests for a decision (Antrag). I also retrieved biennial briefings about the international visits of MPs. At the level of individual MPs involved in the scrutiny of the operation, I searched personal websites for press statements about international activities or EUNAVFOR Med. Furthermore, I retrieved conference proceedings of the IPC CFSP/CSDP through the platform InterParliamentary EU information eXchange (IPEX), and searched the websites of Europarties and EP party groups for positions towards EUNAVFOR Med. Finally, I relied on official EU publications to reconstruct decision-making processes about the operation.

For the study on election campaigns, I most importantly triangulated interview findings with official documents of the three German parties. This included the parties' national party manifestos and, when retrievable, campaigns plans, and evaluations of election campaigns. I also drew on Europarty manifestos and, when retrievable, European election campaign plans. Through the - archived - websites of the three parties, I furthermore gathered information about the line-up of speakers at all national party congresses of the three parties between 2012 and 2019. Finally, I relied on newspaper articles about visits of foreign party leaders to the SPD, the Greens and the Left. I retrieved these through the database LexisNexis, which is a large electronic database for legal and press documents that also provides access to the archives of German newspapers.

${ }_{19}$ Kleine Anfragen, literally translated as 'small inquiries', are collections of parliamentary questions. They are often between twenty and thirty questions long, but can also be longer or shorter than that. 
Table 14 Strategy of case analysis per chapter

\begin{tabular}{llll}
\hline & Chapter 5 & Chapter 6 & Chapter 7 \\
\hline Dossier & EUNAVFOR Med & National and European elections & Synthesis: EUNAVFOR Med and elections \\
Primary strategy & Within-case analysis & Within-case analysis & Across-case analysis \\
\hline Cases within the dossier & SPD, Greens, the Left & SPD, Greens, the Left & SPD, Greens, the Left \\
Primary strategy & Across-case analysis & Across-case analysis & Across-case analysis \\
\hline
\end{tabular}

Table 15 Number of interviewees per dossier and case study

\begin{tabular}{|c|c|c|c|c|c|c|c|c|c|c|c|c|}
\hline & \multicolumn{5}{|c|}{ EUNAVFOR Med } & \multicolumn{5}{|c|}{ National and European elections } & Other & Total \\
\hline $\begin{array}{l}\text { Number of } \\
\text { interviewees }\end{array}$ & $\begin{array}{l}\text { SPD } \\
7\end{array}$ & $\begin{array}{l}\text { Greens } \\
5^{*}\end{array}$ & $\begin{array}{l}\text { the Left } \\
4^{* *}\end{array}$ & $\begin{array}{l}\text { Other } \\
2\end{array}$ & $\begin{array}{l}\text { Total } \\
18\end{array}$ & $\begin{array}{l}\text { SPD } \\
6\end{array}$ & $\begin{array}{l}\text { Greens } \\
2\end{array}$ & $\begin{array}{l}\text { the Left } \\
2 * *\end{array}$ & $\begin{array}{l}\text { Other } \\
7\end{array}$ & $\begin{array}{l}\text { Total } \\
17\end{array}$ & $\begin{array}{l}\text { Various } * * * \\
5\end{array}$ & 40 \\
\hline
\end{tabular}

* One interview was conducted with two interviewees.

** One interviewee was interviewed for both dossiers.

*** This particularly includes interviews relevant to chapter 1, for example about party family meetings organised in the fringe of inter-parliamentary conferences. 


\section{Part II}

\section{Practices of transnational party cooperation in the EU}





\section{Chapter 5}

\section{Transnational party activities with a view to the European Union Naval Force Mediterranean20}

In this chapter, I explore the transnational party activities of the German SPD, the Left and the Greens with a view to the EU military operation to combat human trafficking in the Mediterranean Sea, called European Union Naval Force Mediterranean (EUNAVFOR Med). The chapter focuses on the time period from spring 2015 until approximately the end of the eighteenth Bundestag in October 2017. I focus on policyseeking behaviour of the parties in parliamentary office.

Operation EUNAVFOR Med is particularly interesting for the study of transnational party activities of policy-seeking parties. First, the operation has been highly controversial. It was launched in response to the dying of people at Sea on their way to Europe and to what has been called the 'refugee crisis'. Second, the operation was mandated within the EU's area of the CFSP/CSDP. In this area, decision making is in the hands of governments to a much greater extent than in most other policy areas. Hence, the area of foreign policy, in general, and the CFSP/CSDP, in particular, have increasingly been subject to debate about democratic scrutiny of government decisions. For example, in the Inter-parliamentary Conference on the CFSP/CSDP, national and European parliamentarians have battled about who has the legitimate authority to scrutinise the area (Herranz-Surrallés, 2015). And academics have long debated the question if parliaments and parties are actually involved in foreign policy or if politics infamously 'stops at the water's edge' (on this matter in European politics, see e.g. Kesgin \& Kaarbo, 2010; Mello \& Peters, 2018; Rathbun, 2004; Wagner, Herranz-Surrallés, Kaarbo \& Ostermann, 2017).

20 The material in this chapter has been accepted for publication as A. Groen (forthcoming). Loose coordination or ideological contestation? Transnational party activities of German political parties on the EU military operation EUNAVFOR Med. Foreign Policy Analysis. I reworked the format of that article for the purpose of the dissertation. 
With regard to the latter question, recent studies suggest that there is a transnational partisan dimension to foreign and security policy in Europe. That is, the policy positions of national parties that subscribe to the same ideology tend to converge across countries. Wagner et al. $(2017,24)$ show that across Europe, right-wing parties support participation in military missions more than left-wing parties. Chryssogelos (2015, p. 239-243) finds that also competition between the major Europarties and EP political groups on foreign and security policy is based on ideological and integration preferences. Nevertheless, existing literature chiefly focuses on preferences expressed in party manifestos or votes in parliament. Very little is thus known about the transnational behaviour of national parties and the actual transnational contacts along party lines in the area of foreign policy (but see Chryssogelos, 2017; Fonck, 2018).

The structure of the chapter is as follows. Returning to the broad analytical framework of chapter 1, I first set the scene with a discussion of the potential avenues for transnational party activities in the area of the EU's security and defence policy. In the second section, I return to and specify the theoretical argument of chapter 3 to formulate specific expectations about the dossier of EUNAVFOR Med. I briefly discuss the background of the military operation and the role of Germany therein in the third section. In the fourth section, I zoom in on the transnational activities of the German SPD, the Left, and the Greens regarding EUNAVFOR Med. The fifth, and final, part of the chapter contains the comparative analysis of the findings in view of the resourcedependence perspective on transnational party activities in the EU.

\section{1 | Potential avenues for transnational party activities in European security and defence policy}

The EU's foreign policy, and especially its Common Security and Defence Policy (CSDP), has rapidly developed since the late 1990s. Until the end of the Cold War, loose cooperation on foreign policy by the members of the European Community took place within the European Political Cooperation (EPC). The Treaty of Maastricht (1992) integrated the EPC within the European institutions with the creation of the CFSP, but kept decision making in this area in the hands of governments. The Maastricht Treaty also granted the Western European Union (WEU) the authority to make and implement decisions on defence.21

With the Amsterdam (1997), Nice (2001), and Lisbon (2007) treaties, the EU gradually incorporated the WEU. Defence coordination also further institutionalised with the creation of various diplomatic and military bodies (Vanhoonacker, 2005, p. 78-85; Vanhoonacker, Dijkstra \& Maurer, 2010). The EU launched its first operation in 2003

21 The WEU was an international organisation to facilitate defence cooperation between countries in Western Europe. It was originally established in 1948, but was barely active from the mid-1950s to the mid-1980s. It became fully incorporated into the EU institutions with the Lisbon Treaty of 2009. 
and had established a total of thirty-five military and civilian operations by 2017. Decision making in the CSDP, however, remains essentially inter-governmental. The member states decide on most matters by unanimity in the European Council and the Council of Ministers (compare Sjursen, 2011).

Nevertheless, national parties can be transnational 'participants' in decision making on military and civilian missions within the realm of the CSDP (see Chryssogelos, 2017, p. 258-260; Fonck, 2018, p. 1307). Based on the analytical framework of chapter 1, I distinguish four potential avenues for transnational party activities in the EU's security and defence policy, namely the Europarties, the political groups in the European Parliament, the Inter-Parliamentary Conference on the CFSP/CSDP (IPC CFSP/CSDP), and own party organisational structures.

First, national parties could engage in transnational activities through the Europarties. Although there is little literature that explores the role of Europarties in the EU's foreign policy, the work of Chryssogelos (2017) suggests that Europarties can have modest influence. Most notably, to strengthen their own position, Europarties maintain ties with parties outside of the EU. In so doing, they can promote the foreign policy goals of the EU (see e.g. also Holmes \& Lightfoot, 2011; Pridham, 1999b; Von dem Berge \& Poguntke, 2013).

Research shows that the largest Europarties, the EPP, PES, and ALDE, also formulate distinct policy positions on foreign and security policy (Chryssogelos, 2015, p. 229-233). Their positions are in line with general patterns of political contestation on foreign policy between more left-wing and right-wing parties (p. 234-236). The positions of Europarties on the extreme right and left of the spectrum are, however, informed more by opposition to European integration (p. 239; see also Wagner et al., 2017). Europarties also have different priorities in the CFSP/CSDP. Compared to the EPP and ALDE, the PES is critical towards the CSDP, while the EGP and the PEL are strongly opposing (Calossi \& Coticchia, 2013, p. 6-9).

Second, national parties may engage in cooperation with MEPs or staff in the political groups in the EP, either from their own national party or from other member states (see Miklin \& Crum, 2011). Some EP groups, for example, organise occasional multilateral meetings that bring together national parties to discuss a specific, "hot' topic" (Miklin, 2013, p. 31). Political groups may also discuss security and defence issues during regular summits with their counterparts in national parliaments.22

Several EP political groups also regularly organise party family meetings at the Inter-Parliamentary Conference on the CFSP/CSDP. At this conference, representatives from national parliaments and the European Parliament meet annually. They are usually members of parliamentary committees on foreign affairs. The party family meetings bring

22 An example is the 26th Summit of Chairmen of EPP Parliamentary Groups, Retrieved May 10, 2018, from https://www.eppgroup.eu/newsroom/news/national-parliaments-debate-future-of-europeandefence 
together MPs and MEPs attending the conference from the same party family. The meetings have been indicated on the official programme since the 2013 IPC CFSP/CSDP in Lithuania and normally take place before the plenary session. The programmes usually mention family meetings of the EPP, PES, ALDE, and the Greens, and more infrequently also of GUE-NGL and ECR. Whether EP political groups organise party family meetings depends on the presence of MEPs and MPs from these families at the IPC CFSP/CSDP.23

Contacts with the political groups in the EP can also be informal or bilateral. In this respect, however, it is important to note that the European Parliament has few powers in the area of security and defence. It has no veto over military operations, no formal say on the budget of military operations, and has only restricted access to confidential information.

Nevertheless, in practice, MEPs have still taken up an active role, as the EP has informally increased its capacities and influence on the CSDP (e.g. Peters, Wagner \& Glahn, 2014; compare Herranz-Surralés, 2019). Through inter-institutional agreements in 2002 and 2006 respectively, the EP gained limited access to sensitive Council information on security and defence, as well as limited consultation rights with the institutionalisation of joint meetings (Rosén, 2015; Rosén \& Raube, 2018). The Parliament has also provided its opinion on the launch of certain military operations (Barbé \& Herranz-Surrallés, 2008, p. 91). The creation of the European External Action Service (EEAS) in 2010 was another "opportunity" for the EP to "secure access to classified information" (Blom \& Vanhoonacker, 2015, p. 216) and to increase its influence, for example through establishing a close working relationship with the High Representative of the Union for Foreign Affairs and Security Policy (HR/VP) (Rosén \& Raube, 2018, p. 74-75).

Third, the IPC CFSP/CSDP may be an avenue for cooperation as such. The conference was established in 2012 with the goal to enhance exchange of "information and best practices" between national parliaments, and between the latter and the EP (Rules of Procedure, 2014, p. 1). The function of the inter-parliamentary platform is limited, for example by its non-binding character, and by the diverse interests and backgrounds of the participants. This is particularly so in comparison to the Parliamentary Assembly of the WEU that existed until June 2011, which had more extensive control powers and an own permanent secretariat (Marschall, 2008; Herranz-Surrallés, 2014, p. 959). The IPC CFSP/CSDP may facilitate a general exchange of views and information through plenary sessions and working groups (for a review, see Hefftler \& Gattermann, 2015). Early debates were, however, inhibited by tensions between MPs and MEPs, as both national parliaments and the EP both claimed the authority to make decisions in the

${ }_{23}$ E-mail exchange with the Directorate for Relations with National Parliaments in the European Parliament, 4 December 2017. Most group meetings can be found in the programmes of conferences, available via www.ipex.eu. Note, however, that the conference programmes do not always indicate all party family meetings. 
field of foreign and security policy (Herranz-Surrallés, 2014, p. 971-972; compare Herranz-Surrallés, 2019).

Despite such limitations as an inter-parliamentary platform, the IPC CFSP/CSDP could still constitute a useful channel for transnational party activities. That is, the conferences bring together MPs and MEPs who are elected party politicians. Parliamentarians can thus seek cooperation along party lines during IPCs (e.g. Gattermann, 2014). Such contacts may be more fruitful, because parliamentarians from the same party family are more likely to have similar viewpoints and may know each other through other networks (e.g. Miklin, 2013, p. 37). Indeed, besides the plenary and committees, the WEU Assembly was also organised along political groups (HerranzSurrallés, 2014, p. 959). Political groups likewise play a role in the parliamentary assemblies of the North Atlantic Treaty Organization, the Organization for Security and Co-operation in Europe, and the Council of Europe (Marschall, 2007, p. 13).

Fourth and finally, parties have their own party means and structures to engage in transnational contacts. MPs or party staff members can organise visits to or from sister parties, simply make a phone call, or engage in an e-mail exchange (Hefftler, 2015, p. 6; Miklin, 2013, p. 37; Peters et al., 2014, p. 443). Some larger national party groups, such as the groups in the German Bundestag, also have working groups on security and defence policy and on EU affairs, which have the resources to regularly invite external guests.

\subsection{What drives and what conditions transnational party activities in the context of EU military operations?}

Resource dependencies of national parties with a view to the Common Security and Defence Policy

To understand what drives transnational party activities in the context of EU military operations, the focus of this chapter is on the resource dependencies of national parties in the EU that are related to seeking policy success. These resource dependencies are set out in chapter 3 of this dissertation. Table 16 below serves as a reminder.

Importantly, there are some specific difficulties when it comes to the ability of national parties in parliamentary office to scrutinise or influence decisions in European security and defence policy. These have to do with the relatively more (intergovernmental nature of decision making in this field. As Huff (2015) explains:

[The EU's CSDP is] situated at the nexus of two fields that have generally proven problematic for parliamentary scrutiny: foreign and security policy, and EU integration. Many European legislatures have long treated foreign policy as a matter for executive competence, having limited involvement in policymaking and weak scrutiny mechanisms relative to other fields. This problem is often exacerbated in CFSP/CSDP, where policy-making takes place at a level even further removed from national parliaments (p. 396). 
Specifically, decisions about the launch of EU military operations are taken by the national ministers in the Foreign Affairs Council. Political and strategic direction of operations is the responsibility of national ambassadors in the Political and Security Committee (PSC). And the operational direction of military activities is the responsibility of the national chiefs of defence in the European Union Military Committee.

In CSDP, decision making can move fast in response to international emergencies. This makes it difficult for MPs to acquire necessary information and scrutinise operational mandates within the limited time available - even if a parliament has formal capacities in security and defence policy (e.g. Fonck, Haesebrouck \& Reykers, 2019, p. 93; Huff, 2015, p. 397). Moreover, national governments negotiate in secret about the launch of military operations in the European Council. National parliaments thus neither oversee the positions of other member states nor changes of position by the own government (Bono, 2006, p. 440). The "information asymmetries" between governments and parliaments that are prevalent already in EU affairs are thus relatively large in the area of the CSDP (Raunio \& Wagner, 2017, p. 9).

\section{Table 16 | Policy-seeking and resulting resource dependencies between parliamentary parties at the national and EU level}

Resource dependencies related to policy seeking at the national level
Resource dependencies related to policy seeking at the European level
- Political expertise knowledge about preferences of EU actors and national governments (e.g. Crum \& Fossum, 2013a; Hefftler, 2015; Malang, 2019; Miklin, 2013)

- Subject-matter expertise knowledge about technical and normative aspects of EU dossiers (e.g. Crum \& Fossum, 2013a; Hefftler, 2015; Hix \& Lord, 1997; Malang, 2019; Miklin, 2013)

- Procedural expertise* knowledge about procedures of EU policy making (e.g. Crum \& Fossum, 2013; Hefftler, 2015; Miklin, 2013)

Trans-organisational legitimacy to maintain a "coalition of support" and access to resources (Pfeffer \& Salancik, 2003[1978], p. 24-27)

*Note that this resource was not mentioned as an important resource to be acquired from external actors by the German parties in the dossier of EUNAVFOR Med. It was thus dropped from further investigation (see chapter 4, section 4.2).

Transnational party activities can be one way for national MPs and their staff members to redress such information asymmetries. They can, for example, be a route to obtain expertise about the standpoints of actors involved in negotiations and about the highly specialised aspects of EU military operations. Because national parliaments in the EU, and also the EP, have different levels of access to information about scrutiny and 
defence, a party may be able to obtain information from a sister party to which it does not have access in the own national parliament. As Mello \& Peters (2018, p. 8-10) review, such informal sources of influence of parliaments can be highly important. At the same time, the different formal rights of parliaments, as well as the diverging procedures that parliaments and governments follow in practice, may complicate transnational information exchange (Bono, 2006, p. 440; see also Dieterich, Hummell \& Marschall, 2010; Peters \& Wagner, 2011).

\section{Expectations about transnational party activities in the Common Security and Defence Policy}

Chapter 3 develops three sets of theoretical expectations about the conditions under which national parties are prone to engage in transnational party activities with a view to policy seeking. In sum, these are that:

\section{Position within the national political system}

1.3 Opposition parties have more incentive to engage in transnational party activities than government parties (on government/opposition status in CFSP scrutiny see Herbel, 2017).

\section{Existence of (alternative) routes to obtain resources}

2.1 Parties with many alternative networks or much in-house capacity to generate policyseeking resources have less incentive to engage in transnational party activities;

2.2 Parties are more likely to engage in transnational party activities with sister parties that have relevant access to policy-seeking resources.

\section{Ideological coherence of the party family}

3. Parties are more likely to seek cooperation through multilateral channels when ideological coherence within their party family is strong, while they are more likely to rely on bilateral cooperation when ideological coherence is weak.

The resulting expectations about the transnational party activities of the SPD, the Left, and the Greens are mentioned in chapter 3 and substantiated in chapter 4. Before turning to the empirical investigation of these expectations, it is important to note that the area of foreign policy, and in particular of security and defence, is somewhat peculiar concerning the aspect of party ideology. That is, in the academic literature there are different views about the importance of national ideology for the formation of parties' preferences.

On the one hand, some research finds that preferences of parties from the same European party family are more similar than preferences of parties from different families in the same European country (e.g. Hofmann, 2013; Klingemann, Hofferbert \& Budge, 1994; Wagner et al., 2017). Parties on the left side of the political spectrum are generally against the use of force and military troop deployments, except for multilateral humanitarian operations. These so-called 'doves' are wary of resolving conflicts through 
force or the threat of force. Parties on the right side of the spectrum are generally more in favour of the use of force, military expenditure, and troop deployment. They have a higher willingness to take military action and are therefore also called 'hawks' (e.g. Rathbun, 2004; Wagner et al., 2017; for a review, see Raunio \& Wagner, forthcoming).

One explanation for this is that left-wing parties more than right-wing parties emphasize "inclusive foreign policy", "pronounced multilateralism", and "anti-militarism" (Rathbun, 2004, p. 2-3). This emphasis is the result of the general ideological convictions of left-wing parties about equal rights, equal opportunities, and liberty. An important qualification to the observed general tendency is, however, that also parties on the farright generally do not support international military operations. This can be understood by the primary concern of these parties with the national interest (Chryssogelos, 2015; Wagner et al., 2017).

On the other hand, research also shows that the ideological preferences of parties in the same party family can be inconsistent (e.g. Rathbun, 2004). In the European context, some research finds that national interests crucially influence the preferences of parties, especially in Eastern European member states (e.g. Schuster \& Maier, 2006). As a result of factors such as external security pressures, ideologically different parties from the same country adopt the same preferences. These preferences are usually based on the position of the country in international power constellations (Schuster \& Maier 2006, p. 224 and 235). Preferences of sister parties across Europe may also diverge if the decision to employ troops is more politicised in some countries than in others. Finally, some parties may traditionally be more militaristic than others (Kier, 1997, cited in Wagner et al., 2017, p. 36).

Descriptive data from the 2014 CHES dataset on the distribution of parties' positions in the socialist, radical left, and green party families towards EU foreign and security policy, as well as towards international security, indeed indicates that there are differences both between and within the party families.24 Figure 8 visualises that the radical left family is more strongly against the EU's foreign and security policy than the socialist and green families. The distribution of positions within the left family is, however, skewed towards more support, which is mainly due to the positions of the French and Luxembourgish Left.

Figure 9 shows that the radical left opposes troop deployment more than the green family, while the socialist family is on average more in favour. Yet both within the green and radical left family, some parties are more supportive of troop deployment. These are

24 See chapter 4 for an explanation of the dataset and my corrections to the classification of party families in the 1999-2014 CHES trend file. The 2014 codebook explains that the question on EU foreign and security policy (EU_FOREIGN) is "position of the party leadership in 2014 on EU foreign and security policy". The question on international security (INTERNATIONAL_SECURITY) is "position towards international security and peacekeeping missions". I reversed the original CHES scale that runs from 0 (strongly favours COUNTRY troop deployment) to 10 (strongly opposes COUNTRY troop deployment), so that a higher score reflects more support. This makes the data more easily comparable to the data on positions towards EU foreign and security policy. 
most importantly the French parties Radical Party of the Left (Parti radical de gauche, PRG) and anti-capitalist Ensemble! (see Kier, 1997, cited in Wagner et al., 2017, p. 36), and the Estonian and Latvian green parties (see Pennings, 2017). Amongst the Socialists, the Luxembourgish and Estonian socialist parties are more supportive of troop deployment, while the Maltese and Latvian socialist parties are more against (see e.g. Cheskin \& March, 2016; Fiott, 2015).

Figure 8 | Distribution of positions towards EU foreign and security policy of the green, radical left and socialist party families, 2014 (left figure)

Figure 9 | Distribution of positions towards international security and peacekeeping missions of the green, radical left and socialist party families, 2014 (right figure)
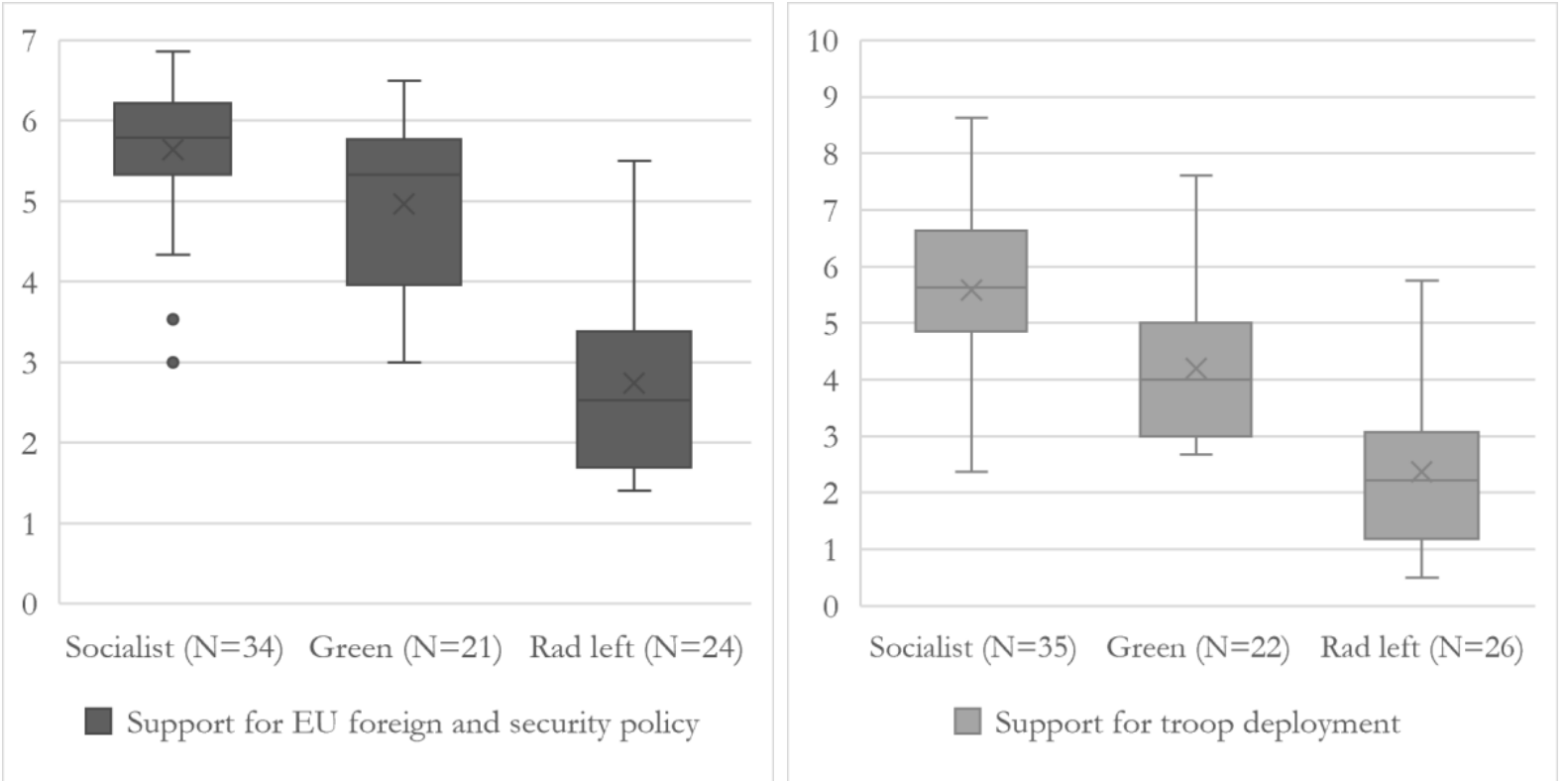

Source: 2014 CHES (Polke et al. 2017) and 1999-2014 CHES trend file (Bakeker et al., 2015).

Note: The scale EU foreign and security policy runs from 0 (strongly opposed) to 7 (strongly in favour). The scale international security and peacekeeping runs from 0 (strongly opposes troop deployment) to 10 (strongly favours troop deployment). None of the indicated outliers are major parties in the European Parliaments or parties from large EU member states. In figure 8, data is missing for the Portuguese Green party MPT, Greek and Spanish Radical leftparties Syriza and IU, and the Irish Socialist Labour. For further information on the data, see chapter 4, section 4.2.

Regarding the distribution of positions within the three families, figure 8 suggests that the socialist family is somewhat more coherent than the green and radical left families when it concerns support for the foreign and security policy of the EU. The range of positions is a little smaller, and the population standard deviation of the socialist party positions is lower (0.809) than those of the green (1.113) and radical left (1.126) families. The image is reversed concerning support for troop deployment. Figure 9 shows that the range of positions of the socialist family is slightly higher than that of the two other families, and also the standard deviation is slightly higher (1.365) than that of the green (1.209) and radical left (1.300) families. 
Figure 10 visualises that the SPD and the Greens are positioned close to the mean of their family, while the Left is somewhat more opposed than the average position.

Because EUNAVFOR Med concerns an international security operation, positions towards troop deployment are arguably more relevant than those towards the EU foreign and security policy as a whole. Therefore, with regard to theoretical expectation (3) about the ideological coherence of the party family, this data implies that the SPD is less likely to seek transnational cooperation through multilateral party channels with a view to EUNAVFOR Med in comparison to the Left and the Greens.

Figure 10 | Distribution of positions towards troop deployment and left/right positions of the Socialist, Green and Left EU party families, 2014

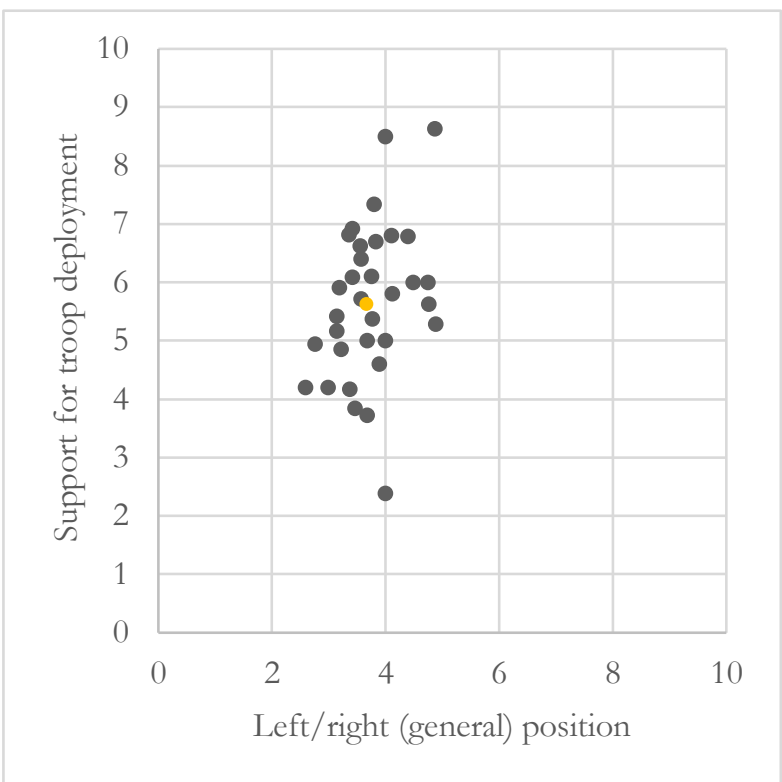

Socialist family $(\mathrm{N}=34$, missing data Maltese PL)

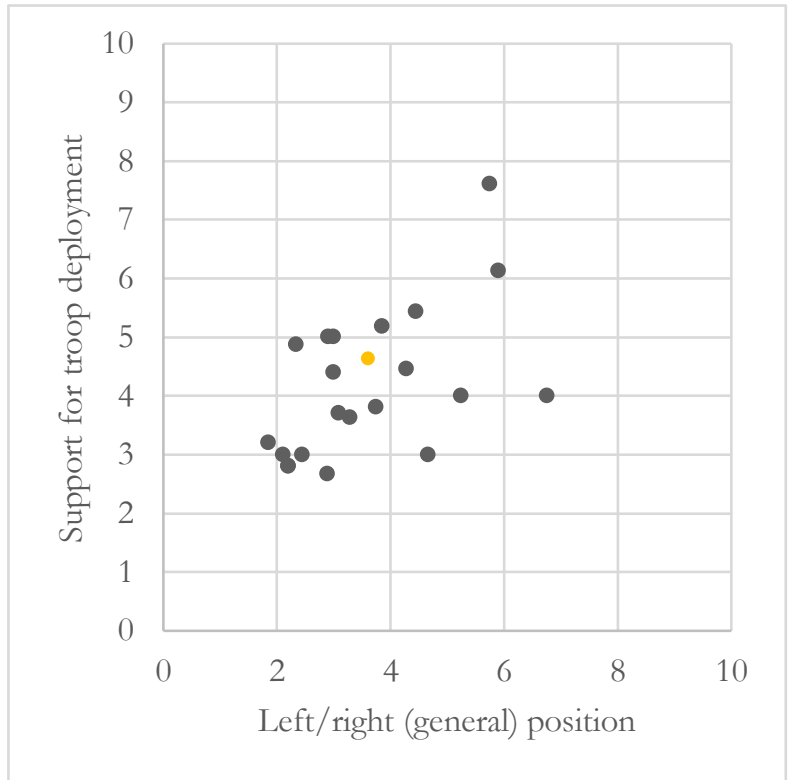

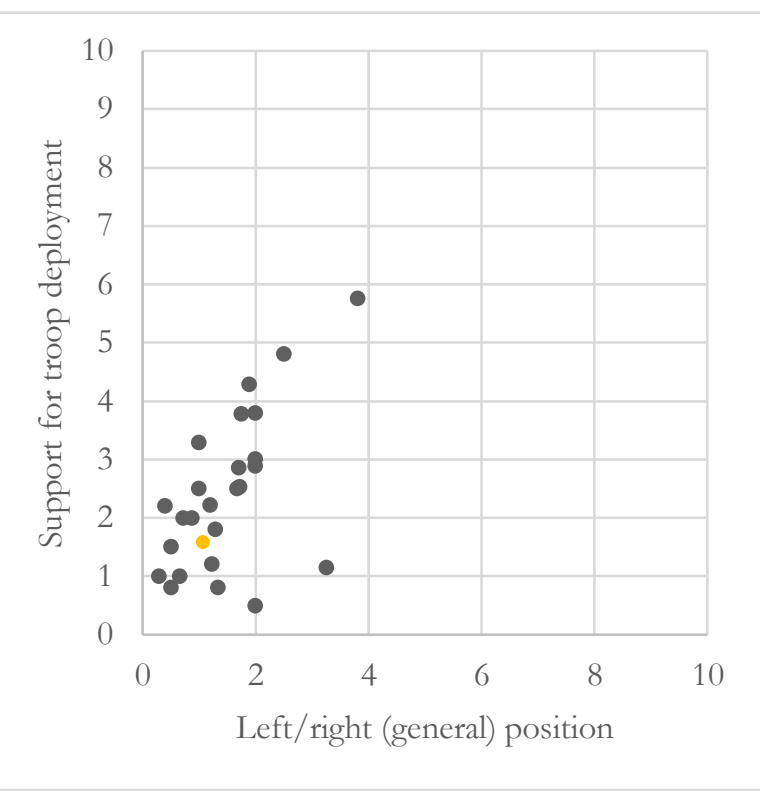

Radical left family ( $N=26)$
Source: 2014 CHES (Polk et al., 2017) and 19992014 CHES trend file (Bakker et al., 2015).

Note: The scale international security and peacekeeping runs from 0 (strongly opposes troop deployment) to 10 (strongly favours troop deployment). The scale left/ right runs from 0 (extreme left) to 10 (extreme right). The German parties are marked with a yellow dot. For further information about the data, see section 4.2 in chapter 4.

Green family $(N=22)$ 


\subsection{The German contribution to operation EUNAVFOR Med}

Germany has been a central actor in the EU Naval Force Mediterranean. Initially, the German government opposed Italian plans for a similar operation in 2013 on the grounds that the operation would serve as a "bridge to Europe" for migrants (Nováky, 2018, p 202). Yet in April 2015, public pressure to intervene increased after 800 people drowned in a shipwreck (p 202). Hence, in May 2015, and after bilateral agreement with the Italian government, the German government sent two ships to the Mediterranean Sea that were originally deployed in the EU anti-piracy operation EUNAVFOR Atalanta in the Horn of Africa (Deutscher Bundestag, 2015b, p. 1).

Operation EUNAVFOR Med was then launched by the Council of Ministers on 22 June 2015, with the contribution of almost all EU member states. It was the immediate result of a special meeting of the European Council to discuss the dying of people on the Mediterranean Sea, convened in April 2015. The official purpose of EUNAVFOR Med was to "disrupt the business model of human smuggling and trafficking networks in the Southern Central Mediterranean and prevent the further loss of life at sea". The core mandate was "to undertake systematic efforts to identify, capture and dispose of vessels and enabling assets used or suspected of being used by migrant smugglers or traffickers" (EEAS, About EUNAVFOR Med). The operation covered the area in the Southern Central Mediterranean between Italy and Libya, approximately from Sardinia to Crete, including the waters east to Tunisia.

EUNAVFOR Med was foreseen to consist of three phases. The first phase most importantly concerned the gathering of information about ongoing smuggling. Phase two consisted of the "boarding, search, seizure and diversion of vessels suspected of being used for human smuggling or trafficking" on the high seas. Upon approval of the United Nations Security Council (UNSC) and Libya, this would also include the territorial waters of Libya. In phase three, again upon approval, the mandate would be extended to include "all necessary measures (...), including disposing of (vessels) or rendering them inoperable" (Council, 2015a).

Particularly the third phase of the operation, during which troops would be authorised to destroy boats used for human trafficking, has been highly controversial as well as far-reaching in comparison to previous missions (Faleg \& Blockmans, 2015). The decision of the Council of June 2016 to extend the mandate of EUNAVFOR Med to include training of the Libyan coast guard has likewise been controversial (e.g. House of Lords, 2017). In spring 2019, after Italy changed its position towards the operation, EUNAVFOR Med was scaled down. The Council entirely suspended the deployment of ships. The operation only maintained limited air assets, along with the training of Libyan coast guards (Council of the European Union, 2019; Rasche, 2018, p. 4). 
Germany has been the largest contributor of assets and staff to EUNAVFOR Med, together with France.25 During the peak of the operation, the German government contributed 522 soldiers, whilst it had a Bundestag mandate to deploy up to 950 troops (Deutscher Bundestag, 2018b, p. 9). By far and large, this concerned troops on marine ships. EUNAVFOR Med is also connected to other military and border control operations in the Mediterranean to which Germany contributes. These most importantly include NATO operation Sea Guardian, previously known as Operation Active Endeavour, and Frontex operation Themis, previously known as Triton.

Under the German troop deployment law, the Bundestag must approve the deployment of troops. The parliament additionally approves extensions of or changes to the mandate of an operation. From the launch of the operation until summer 2018, the Bundestag took four decisions about EUNAVFOR Med (Deutscher Bundestag, 2015a; 2016a; 2017a; 2018a). By mid-September 2015, the German government made a first request to approve a German contribution to phase 2 of EUNAVFOR Med (launched in early October 2015). The decisions of the Bundestag on EUNAVFOR Med are summarised in figure 11, along with the main decisions of the Council on the operation.

Following the procedures of the Bundestag, government requests went through a first plenary reading. The Foreign Affairs committee then drew up recommendations for a decision, based on the opinion of other committees involved. On EUNAVFOR Med, these were the committees on Law and Consumer Protection, Defence, Human Rights and Humanitarian Aid, and Economic Cooperation and Development. The Budgetary committee assessed whether the deployment was compatible with the budget. A second reading in the plenary followed, after which the plenary voted. After the launch of an operation, the Defence committee is charged with daily scrutiny (Deutscher Bundestag, The defence committee).

\section{4 | Transnational party activities of German parliamentary parties on operation EUNAVFOR Med}

Policy goals about EUNAVFOR Med of the SPD, the Greens and the Left

The SPD, the Greens, and the Left have had different policy goals with a view to the EU Naval Force Mediterranean. As the junior government party, the SPD voted in favour of the various Bundestag decisions on the military operation, although in each roll call vote a handful of MPs from the SPD voted against. This is, however, common within the SPD, for example because a few MPs identify as pacifists (interview 5 and 17). By contrast, the opposition parties the Greens and the Left unanimously voted against the military operation (Deutscher Bundestag, 2015d; 2016b; 2017b; 2018c). 
Figure 11 | Key decisions on EUNAVFOR Med at EU and German level, April 2015-June 2018

Decisions at EU level

Decisions at the German level

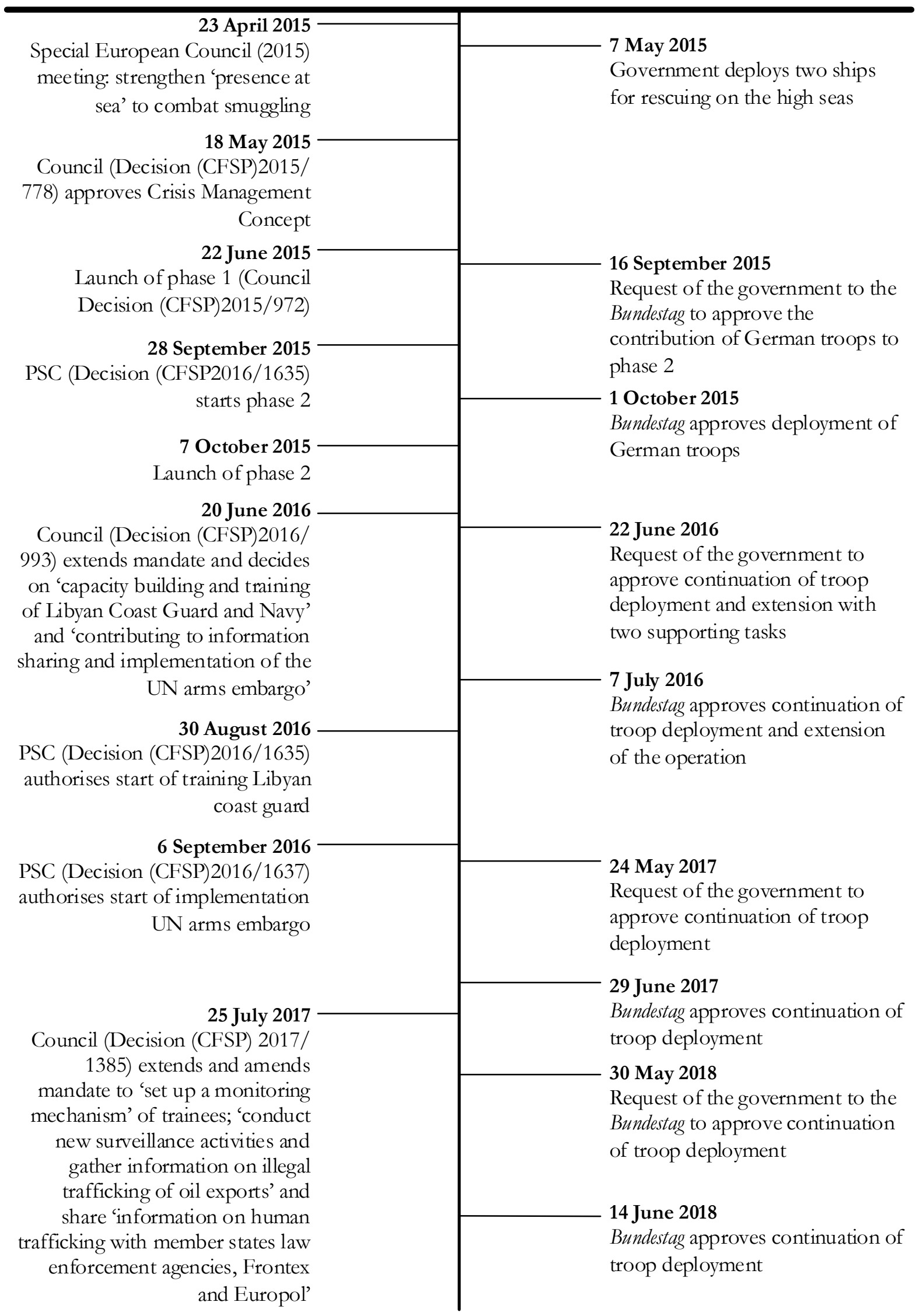

Source: own compilation from websites of the European External Action Service (EEAS) and of the German Bundestag. 
To explain the support of the SPD for a German contribution to phase 2 of EUNAVFOR Med, MPs mentioned the necessity of the operation to fight the criminal activities of human smugglers and to "destroy [their] business model" (2015d, p. 12342; 2015c). At the same time, they stressed that a strategy to resolve the crisis in the Mediterranean required several "building blocks" (2015c, p. 12060) or "mosaic pieces" (2015d, p. 12342), of which actions against smuggles would only be one. In this context, MPs also talked about the importance of the creation of "legal routes for immigration" (e.g. 2015c, p. 12060) and of continuing efforts to rescue people who are shipwrecked (e.g. 2015d, p. 12334). Similar language was used in later debates (e.g. 2016c, p. 17867; 2017b, p. 24925). Interviewees from the SPD likewise said that it was important to them that EUNAVFOR Med would not be the only element in a European response to the situation in the Mediterranean (interviews 3 and 7).

The Greens only supported the first phase of operation EUNAVFOR Med. They had also supported several other operations that "fight the symptoms" of larger underlying problems, including the launch of the counter-piracy operation EUNAVFOR Atalanta (Deutscher Bundestag, 2015c, p. 12057).26 In the plenary debates about the mandate for a German contribution to phase 2 of EUNAVFOR Med, however, MPs stated that the Greens could not live with the operation's priority with information gathering, rather than with rescueing people at sea (p. 12057; 2015d, p. 12339). In the debates about the extension of the mandate with the training of Libyan coast guards, MPs stressed that the combat of human trafficking required police rather than military actions, as well as the creation of "legal and safe immigration routes" (2016c, p. 17865; 2016b). Interviewees likewise explained that for the Greens, it was most important to make the rescuing of migrants and refugees at sea the priority of German troops, to stop military actions against smugglers, and to create safe routes to Europe (interviews 1 and 10). The training of Libyan coast guards was also a key question (interview 10).27

The Left has not voted in favour of the deployment of German troops for any mission ever since the first German foreign deployment of troops in 1992 (Ostermann et al., forthcoming). In the plenary debates about the German contribution to EUNAVFOR Med of 2015, one MP called the mandate a "sad high point of your [the government's] policy of sealing off borders" (Deutscher Bundestag, 2015c, p. 12055). Another MP likewise saw "the real goal" of EUNAVFOR Med as "preventing refugees from coming to Europe" (2015d, 12336). One interviewee indeed also commented on the "salami tactics" of the operation, namely that the operation brought in the military with limited tasks at first, but then sought to extend tasks step by step (interview 2). In later debates about extensions of the mandate and operation, an MP named the operation a "defence

26 For data on the parliamentary votes on the deployment of armed forces in the German Bundestag since July 1993, see the Parliamentary Deployment Votes Database (version 2) (Ostermann et al., forthcoming). ${ }_{27}$ See also the motions (Entschliessungsantrag) of the Greens in the Bundestag files 18/6208, 18/9069, $18 / 12967$ and $19 / 2708$. 
mission against refugees" (2016c, p. 17861) and mentioned that the Libyan coast guard took over the "dirty job" of EUNAVFOR Med, which was to bring migrants at sea back to Libya (2017b, p. 24927). Interviewees from the Left stressed the importance of legal migration routes important, and, unlike the Greens, called for the complete abolishment of EUNAVFOR Med and the launch of a civil rescuing programme (interviews 2, 4 and 9; see also 2015d, p. 12336).28 Hence, while both the Greens and the Left voted against a German contribution to EUNAVFOR Med, their arguments to do so and their own policy demands towards the operation differed.

\section{Transnational party activities to acquire political expertise for arguments in the national debate}

All three parties engaged in transnational party activities to acquire political expertise. Both during the discussions about the launch of operation EUNAVFOR Med and over the course of the operation, they sought after knowledge about the policy preferences of national governments in other EU member states and of the EU institutions. MPs and parliamentary staff members from the Greens, however, attributed more importance to political expertise than those from the SPD and the Left. Interviewees from all parties also mentioned limits to their transnational exchanges. Activities to acquire political expertise on debates surrounding EUNAVFOR Med often occurred through the InterParliamentary Conference on the CFSP/CSDP, and through contacts with the own national party group in the EP.

For the Greens, knowledge about the positions of EU actors and governments involved in decision-making processes on EUNAVFOR Med was of particular importance. Crucially, interviewees explained that it was difficult to acquire timely information about the actions of the German government and the preparatory work for a military operation in Brussels, particularly during the early stage of decision making. This included information about the Crisis Management Concept (CMC) and decision making in the Council (interview 1). Indeed, in late October 2015, the Greens filed a complaint against the government to the German Constitutional Court (Bundesverfassungsgericht). This was because the government had not provided the Bundestag with access to the draft CMC of the High Representative prior to the Council meeting of May 2015, at which EUNAVFOR Med was approved (Organstreitverfahren, 2015). In plenary debates about the launch of the operation, an MP also complained about information only being made available in the Document Security Office (Geheimschutzstelle), thereby restricting access (2015c, p. 12057). Another MP likewise mentioned the problem of late access to documents (2016b, p. 18108).

In this context, the Greens had initially hoped and expected that the IPC CFSP/CSDP would help to address a lack of early and timely information, because of its nature as a platform of parliamentarians rather than of governments (interview 1). Indeed, 
one interviewee mentioned that the fact that the conference brings together parliamentarians from across the EU served as an important reason to attend the conference in the first place (interview 14). In practice, however, the IPC CFSP/CSDP was not seen as a helpful avenue to acquire the necessary early information about decision making, most importantly because national interests dominated the discussions. Parliamentarians oftentimes defended their respective national government (interview 1).

Nonetheless, for several interviewees at the Greens, precisely the expression of national interests made the IPC an interesting and also important venue to attend. The discussions helped to acquire an overview of political argumentations on EUNAVFOR Med by relevant European and national actors (interviews 1 and 14). In this experience, the conference was an important place to learn about different perspectives and to acquire arguments that had not been made in the national realm before (interview 14). In addition, one interviewee commented positively on the role of HR/VP Mogherini at the IPC CFSP/CSDP in debates about the 'refugee crisis'. Mogherini took the stage to talk about the situation at the Mediterranean Sea, showing a strong moral sense of responsibility in her speech. To the interviewee, listening to discussions in which different viewpoints are exchanged, for example in response to the speech by the HR/VP, helped to become more informed - also compared to colleagues in the Bundestag not attending the conference. Hence, ultimately, knowing about the arguments of others helped to develop and improve arguments about EUNAVFOR Med for debates in the Bundestag (interview 1).

For interviewees from the SPD, the IPC CFSP/CSDP also functioned as a place to learn about what debates took place in other national parliaments and what the partypolitical positions of other actors were (interviews 7 and 11). Indeed, for one interviewee, the IPC was the most important place for transnational exchange about EUNAVFOR Med. The semi-annual conference, however, had taken place already in mid-March, just before the debates about the launch of the operation started in April 2015 (interview 11). Another interviewee found that attending the conference was primarily about "broadening the horizon". They exchanged opinions and discussed with colleagues from other countries, including, anecdotally, about the situation in different countries during the 'refugee crisis'. Such exchanges contributed to a better common understanding of how social democrats in different countries took decisions (interview 7), and of the political and historical background of national discussions (interview 11).

A second important aspect of the IPC CFSP/CSDP for interviewees of the SPD was that it provided MPs with an opportunity to network (interviews 7 and 11). They learned who the contact persons in other parliaments are, which is helpful if one wants to pursue initiatives at the European level (interview 11). Moreover, the conference provided an opportunity to socialise with the own national colleagues from other party groups, simply because the setting of being abroad together allowed for the time to have a drink in the evening. This contributed to a better understanding of each other's argumentation 
and viewpoints and thereby also benefitted parliamentary work at home in the Bundestag (interview 11; also interview 16).

Overall, however, interviewees from the SPD ascribed a lower level of importance to the IPC CFSP/CSDP for activities in the national realm than interviewees from the Greens. This was the case both in terms of the general importance of the conference, as well as in the context of debates about the response to the crisis in the Mediterranean Sea (interviews 7 and 11). One interviewee, for example, stated that they could not "concretely use" the conference beyond learning and deepening knowledge about different viewpoints. They ascribed this to a lack of continuity resulting from the rotating presidency of the conference and to the absence of a formal role EP in the mandating of EU military operations (interview 7). Moreover, the composition of the IPC fluctuated much, because national delegations changed after elections (interviews 7 and 11).

MPs from the Left, like those of the Greens, also complained about a lack of timely and complete information from the German government. During the debate about the vote on the first mandate for the deployment of German troops to operation EUNAVFOR Med, one MP, for example, found it highly problematic that only MPs from the parliamentary committees on Foreign Affairs and Defence were given access to the CMC through the Document Security Office. This access was also only provided less than a week before the parliamentary debate. Moreover, they commented that MPs only had half an hour to read the CMC, while the document was 677 pages long (2015d, p. 12338; see also 2018d, p. 3435-3436).

Despite this, at the Left, interviewees put relatively little emphasis on the importance of the resource of political expertise about operation EUNAVFOR Med. 29 The radical left EP party group, GUE-NGL, and the Left in the Bundestag regularly mutually communicated their positions (interview 12). One interviewee discussed that information from radical left party family meetings helped to increase awareness within the national party group and specifically within the working group (Arbeitskreis) on foreign affairs. This awareness concerned issues that should be followed up in more depth in parliament or through public relations (interview 4). Relevant party family meetings were meetings of the working groups of the Party of the European Left - most importantly the working groups on migration and on the Middle East, but also the working group on peace - as well as meetings of the Mediterranean Conference of the Left. The latter is a cooperation format of the Party of the European Left with left parties from regions around the Mediterranean Sea.

Also interviewees from the Greens and the SPD mentioned avenues beyond the IPC CFSP/CSDP to acquire political expertise on operation EUNAVFOR Med. At the Greens, most contacts happened informally between MPs and German MEPs, as well as 
between staff members (interviews 10 and 13). This was often on the own initiative of MPs or MEPs (interview 1). In the experience of one interviewee, contacts with MPs from other member states were rare (interview 10). Another interviewee mentioned that they were also in touch with parliamentarians from other member states via e-mail and telephone, but that they especially engaged in contact with the Greens in the European Parliament concerning the operation (interview 13). They explained that this helped to acquire information about how the military operation was viewed in other countries and that they hence obtained a broader perspective on the operation (interview 13).

Informal contacts may have been especially important in the case of very contentious mandates (interview 1). One interviewee, for example, explained that there had been contacts with the party in the European Parliament about operation EUNAVFOR Atalanta, the anti-piracy operation in the Horn of Africa. This concerned the controversial aspect of surveillance and actions over land. As the German government promised to renegotiate this, the Greens used contacts in the EP to acquire information on the progress of these negotiations, which helped to develop a stronger argument in the Bundestag. Hence, contacts to Brussels helped to better understand what motivates EU decisions (interview 10).

With regard to contacts between MPs and MEPs of the SPD, some interviewees mentioned that - with the exception of bi-annual mutual visits - such relations generally did not exist with a view to normal parliamentary business about security and defence (interviews 3 and 7). Other interviewees discussed that contacts did take place both at the level of staff and of parliamentarians, but mostly on an informal and personal basis including through WhatsApp groups (interview 11). They did not recall any contacts on EUNAVFOR Med, but mentioned the examples of Permanent Structured Cooperation (PESCO) and EU-Israel relations (interviews 5 and 11). Some explained the absence of contacts on operation EUNAVFOR Med by the lack of a formal say of MEPs on military operations (interviews 3 and 11). Indeed, one interviewee remarked that connections between MPs and MEPs in the area of foreign affairs functioned better on topics in which the EP is more involved, such as on the European defence industry (interview 15).

Concerning contacts with social democratic parliamentarians from other member states, one interviewee mentioned an occasional phone call with the social democratic Italian head of the defence committee about the 'refugee crisis', as this was also an important topic in the German media. They called the Italian colleague to ask about what went on in the Italian parliament in view of the crisis in the Mediterranean (interview 11). At various conferences, there were also general exchanges on security and defence with MPs and MEPs from different member states and parties. One interviewee provided the example of the annual Cercle Stratégique Franco-Allemand organised by the Friedrich Ebert Foundation (FES), at which the situation in the Mediterranean Sea was on the agenda.30

\footnotetext{
${ }_{30}$ Crises in the Middle East and North Africa were on the agenda of the 30th meeting in 2017, while migration, development and security issues in Africa were on the agenda of the $31_{\mathrm{st}}$ meeting in 2018. No 
They explained that one added value of attending these meetings may be to better understand the debates that take place in France (interview 5). Conferences also served as a basis for closer personal relations in the future (interview 11).

\section{The use of established sources of subject-matter expertise in the national debate}

In contrast to the previous resource of political expertise, the parliamentary groups of the SPD, the Greens, and the Left all had sources of subject-matter expertise that were more established and directly accessible than information from transnational contacts. Hence, in their domestic debates on operation EUNAVFOR Med, parties by far and large made use of established sources and networks to acquire information about the technical and normative aspects of the operation. Nevertheless, there is limited evidence of transnational party activities that were driven by a need to obtain subject-matter expertise with a view to debates in the national realm. This particularly concerned contacts with the own party group in the European Parliament, especially on the side of the Left.

For the SPD, government and ministerial sources were vital for the decision about the mandate to contribute German troops to EUNAVFOR Med (interviews 5, 7 and 17). As a government party, it was highly important to be involved in decision making prior to the formal executive decision on the mandate, so as to ensure majority support in the Bundestag (interview 17).31 In this consultation process, there was close, informal contact about the content of the operation's mandate between the SPD group in parliament and the party in government (interviews 3 and 5). One interviewee, for example, described themselves as having two conflictual roles, namely to both control and to support the government. To be able to flag agreement or disagreement with the mandate at a preliminary stage, they relied on consultation processes outside of the parliament. Given the speed of decision making, these consultation processes took place under high time pressure, so that only a few MPs could take part in them. The process hence required high levels of trust in those leading the negotiations of the SPD (interview 3). There were no major debates about the EUNAVFOR Med mandate within the SPD, but at a later stage there were questions from within the party about the training of Libyan coast guards (interview 5 and 17).

Also over the course of EUNAVFOR Med, the SPD relied on government information (interview 3, 5, 7 and 17). This included most importantly the weekly

topics related to migration or security around the Mediterranean were on the agendas of the 2015 and 2016 meetings. Information retrieved from https://www.fesparis.org.

31 This finding, and also the similar finding below about the Green party, supports the argument of Mello and Peters (2018) that informal sources of parliamentary influence are important in the area of security policy. The interviews, however, did not provide evidence that this informal influence also led to substantial changes in the mandate for the deployment of German troops to EUNAVFOR Med to ensure majority support (Mello 2019). One interviewee indeed explained that it was relatively easy to secure support as there was a 'grand coalition' of the time that could count on a very large majority in the Bundestag (interview 5). 
government updates about all operations in which German troops are deployed (Unterrichtung des Parlaments) (interviews 7 and 17). Interviewees mentioned that they could also directly request information, such as from ministries or from the Chief of Defence of the German armed forces (Generalinspekteur) (interviews 3 and 17). Because the Minister for Foreign Affairs was also from the SPD, there were close links to this Ministry. This brought about an informal flow of information (interview 5). One interviewee, however, remarked that contacts with the ministry were not always efficient, as it tends to operate through a rather hierarchical and formalised structure (interview 11).

Other sources of information for the SPD were the media, NGOs - particularly those active in rescuing operations at the Mediterranean Sea - and research institutes, such as the German Institute for International and Security Affairs (SWP) and the Center for International Peace Operations (ZIF) (interview 5). One interviewee also referred to the parliamentary scientific service as an important source of information (Wissenschaftliche Dienste) (interview 3). Finally, there were contacts to military staff employed in the operation, including also military staff from other EU member states (interview 3) and personal contacts to high-ranking German soldiers (interview 17). The latter were particularly valuable to obtain information on short notice (interview 17).

Government information was likewise an important source of information about the content-matter of operation EUNAVFOR Med for opposition parties the Greens and the Left. One interviewee from the Left explained that they received all necessary information about the goal and course of the operation from the Federal Foreign Office and Ministry of Defence, while they also drew on information from the media (interview 12). Similarly, an interviewee from the Greens mentioned that regular government updates about the operation, as well as information from the Commission's EEAS, served as the most important sources to scrutinise the operation. While they found information from the newspapers also very relevant, they saw this as a source that was additional to the government updates (interview 13). In this context, the Greens also generally tried to meet the government during the initial decision-making processes to attempt to change the content of an operation's mandate, also before mandate extensions. This is because once a government request for a parliamentary decision about a mandate reaches the Bundestag, MPs can only approve or disapprove the mandate as a whole (interview 1), leaving little room to steer policy through the work of the committees (interview 10).

Nevertheless, compared to the SPD, interviewees from the Left and the Greens attributed particular importance to other sources of subject-matter expertise than government information. Indeed, as discussed above, both the Greens and the Left complained about the difficulty of getting timely, clear and sufficient information from the government on EUNAVFOR Med (also interviews 1, 2 and 4). At the Left, one interviewee, for example, explained that they found the weekly updates about the operation EUNAVFOR Med highly incomplete. Information was presented solely from a 
military perspective and focused on the risks for the German troops. They hence saw it as their task to research what really happened on site (interview 4).

When asked about their sources for subject-matter expertise, interviewees of the Greens most importantly brought up the press, NGOs, research institutes, and think tanks (interviews 1, 10 and 14), such as the SWP and the European Council on Foreign Relations (interview 10). One interviewee also brought up the importance of access to mission reports through EuDox, which is the information system of the German Bundestag that provides access to EU-related documents (interview 10). Finally, information from people directly involved in EUNAVFOR Med was considered highly valuable, including also from diplomatic personnel (interviews 1 and 10). This helped to evaluate how the operation functioned in practice (interview 1).

Both at the Left and the Greens, interviewees also mentioned government responses to parliamentary questions (Kleine Anfragen) as an important source of additional information about EUNAVFOR Med (interviews 2, 10 and 14). At the Greens, one interviewee explained that they used information from external sources to formulate questions so as to obtain further or new information (interview 10). At the Left, an interviewee likewise discussed that they asked parliamentary questions with the aim to obtain further information. They used the privileged access of the Bundestag to EU documents and cables to do so (interview 2). During the 18th Bundestag, the Greens indeed sent three parliamentary questions that referred to operation EUNAVFOR Med and one that was entirely about the operation. The Left sent 33 questions that referred to operation EUNAVFOR Med, as well as eight questions that were entirely devoted to it.32

Indeed, for the Left, the latter strategy of questioning the government on the content of operation EUNAVFOR Med was crucial. As one interviewee explained, this strategy required arguments to prove the 'wrongfulness' of the operation. To develop such arguments, they needed highly in-depth knowledge about the situation on the Mediterranean Sea and in Libya. This, for example, concerned knowledge about the construction of a Maritime Rescue Coordination Centre (MRCC) in Tripoli with the help of Italy and funded by the EU (interview 2). This MRCC would potentially facilitate operation EUNAVFOR Med to pass on information to the Libyan coast guard.

To obtain the subject-matter knowledge to develop parliamentary questions, besides newspapers (interviews 2 and 4) and social media (interview 2), the Left has also maintained contacts within a broad network of human right organisations and left-wing activists (interviews 2 and 4). This included ties between MPs or their staff and rescuing organisations, such as Sea-Watch (interview 2 and 9). The network of the Left was

32 I retrieved all Kleine Anfragen that mentioned operation EUNAVFOR Med through the Documentation and Information system of the German Bundestag (DIP), using the search term "EUNAVFOR Med". The DIP retrieved 45 questions. The search term "Operation Sophia" did not lead to any additional questions. I categorised the questions based on the party group by which they were asked, namely the Greens or the Left. The SPD and CDU/CSU party groups did not send any Kleine Anfragen about operation EUNAVFOR Med. 
partially the result of the personal background of staff members who were or had been active in them and of their personal connections to activists (interviews 2 and 4). One interviewee, for example, mentioned that, through their personal network, they received important information about harmful actions of a Libyan boat at sea. They used this information in parliamentary questions (interview 2). Another interviewee explained that they had long been active in the German peace movement (Friedenbewegung), which also maintains connections to the solidarity movements for refugees. As such, they had personal links to people active on the NGO ships in the Mediterranean Sea. This provided them with information about what happened on site (interview 4).

In addition, to support the strategy of questioning the government on EUNAVFOR Med, the Left engaged in some exchange of information on the operation through the own national party group in the EP. Here, exchange with a German MEP of the Left who actively followed the dossier of the operation worked both ways. On the one hand, the offices of the MPs forwarded information to that of the MEP, because MPs often had better access to information than MEPs. Indeed, interviewees in the Bundestag explained that they had relatively privileged access to information about military operations compared to the EP, and also compared to opposition parties in other EU member states (interviews 2 and 4). One interviewee also said, however, that they had not been in touch with parliamentarians from other EU member states on EUNAVFOR Med specifically. Such contacts had taken place with Danish parliamentarians regarding Europol (interview 2).

On the other hand, the office of an MP of the Left in the Bundestag coordinated questions on EUNAVFOR Med with the office of a German MEP of the Left. The aim of this endeavour was in fact to obtain information from the Commission. That is, only MEPs can ask questions to the High Representative of the Union for Foreign Affairs and Security Policy. Answers to these questions were subsequently used in a Bundestag debate and in questions to the national government (interview 2). Indeed, references to questions asked by MEPs to the Commission can be found in three of the parliamentary questions of the Left in relation to operation EUNAVFOR Med. These questions particularly concerned the relation between the activities of EUNVOFR Med and the introduction of Libya into the "Seahorse" communication network for border surveillance.33 Another interviewee, however, mentioned that the MEP often did not receive answers from the Commission (interview 4).

Green MPs also engaged in regular informal written and telephone communication via the own network at the EP in Brussels. This was to acquire additional information about the content of EUNAVFOR Med or to exchange information (interviews 10, 13 and 14). One interviewee, for example, mentioned that a German policy advisor at the Greens/EFA group in the EP was an important contact person, whenever they faced a need to know something (interview 14). On the side of the SPD, interviewees did not 
recall contacts with their counterparts in the EP specifically about the subject-matter of EUNAVFOR Med. One interviewee explained that in general, whether such contacts take place depends on whether there is a parliamentarian or staff member in the EP who is active on the issue (interview 5).

\section{Transnational party activities to coordinate collective political positions at the European level}

The three German parties in parliamentary office made limited attempts to pursue their policy preferences regarding operation EUNAVFOR Med at the European level. If transnational party activities to participate in the formulation of collective political positions within the party family primarily took place, this was often at the level of the party in central or in government office, or in the European Parliament. Some activities, however, were pursued by MPs or staff member from the party in parliamentary office. Interviewees brought up examples of such activities taking place at the IPC CFSP/CSDP, through conferences of the Europarty, and through bilateral contacts.

With regard to the Left and the Greens, there is evidence for common viewpoints towards operation EUNAVFOR Med within the respective party families. In September 2015, when the European Parliament debated a draft Resolution on migration and refugees in Europe ((2015/2833(RSP), both the political groups GUE-NGL and Greens/EFA tabled motions in which they opposed EUNAVFOR Med. In their motion, GUE-NGL "call[ed] for the EU and its Member States to end the EUNAVFOR Med operation" (European Parliament, 2015a, p. 6). The Greens/EFA “object[ed] to the EUNAVFOR Med operation" and "reject[ed] the High Representative's initiative to launch phase two of the operation" (European Parliament, 2015b, p. 7). Similar statements can be found in documents of Congress or Council meetings of the European political parties of the Greens and the Left (e.g. European Green Party, 2015, p. 2; p. 12).

From the side of the party in parliamentary office, the Greens also made some attempts to foster common positions towards the naval operation. Most prominently, they sought to coordinate positions with other green parliamentarians present at the IPC CFSP/CSDP (interviews 1 and 14). Such coordination occurred informally during the conference (interview 14), but also at party family meetings prior to or during the interparliamentary conference, for example in Luxembourg in September 2015 and in The Hague in April 2016 (interviews 1 and 14).34 One interviewee explained that, contrary to the larger party families, these party family meetings often had to be initiated by the Greens themselves, as they were not logistically facilitated (interview 1). To prepare these meetings, there was close contact with a staff member of the Green party group in the EP. This helped to acquire the contact information of green parliamentarians who would attend the IPC, so that these could be contacted beforehand (interview 14). Positions that

34 The Greens/EFA party meeting is indeed on the agenda of the 2015 IPC CFSP/CSDP in Luxembourg, but not on that of the 2016 conference in the Hague, which does not mention any party family meetings. Both are available via www.ipex.eu. 
were coordinated amongst the green parliamentarians at the IPC CFSP/CSDP were subsequently used in the negotiation process for the final conclusions of the conference.

For the Left, it was important to oppose a perceived right-wing response to the crisis in the Mediterranean (interviews 2, 4 and 9). Attempts of the Left to foster common positions included transnational party activities through various avenues. To start with, EUNAVFOR Med and the crisis in the Mediterranean were a theme in bilateral conversations with sister parties to rally for an explicit and united "pro-refugee" standpoint. Such conversations, however, took place mostly at the central party level (interview 9). Moreover, discussions about common perspectives on the 'refugee crisis' in general took place within the respective working groups of the Party of the European Left (interviews 4 and 9) and at the Mediterranean Conference of the LEFT (interview 4). The focus of the latter conference was primarily on networking (interview 4). Nevertheless, the conference did publish a declaration that put forward collective positions of radical left parties from Europe, the Middle East, and North-Africa. On EUNAVFOR Med, the declaration of the 2017 conference in Malaga read "We denounce the process of the 'externalization of EU border control' by making the North African states the border guards at EU in order to hold migrants out of Europe", as well as:

All military operations such as EUNAVFOR Med Sophia aiming to contain migration must be terminated. Border control mechanisms such as FRONTEX must be replaced by multinational search and rescue operation in order to put an end to the ongoing tragedies in the Mediterranean (Declaration of the Third Mediterranean Conference).

In contrast, within the social democratic party family, there is little evidence of a common policy stance towards EUNAVFOR Med at the level of parties in central office - neither of the Socialists \& Democrats group in the EP, nor of the Party of European Socialists. In view of the debates in the EP in September 2015, the S\&D group filed a motion in which it "takes note of the launch of EUNAVFOR Med" (European Parliament, 2015, p. 7). In June 2016, the PES adopted a declaration outlining "ten points to tackle the refugee challenges", but it makes no mention of operation EUNAVFOR MED, nor does it provide a judgement about the desirability of a military operation. Moreover, the Czech CSSD, in government at the time, and Danish SD, in opposition at the time, declared themselves unbound by it (Party of European Socialists, 2016). At the preparatory meeting of the PES leaders for the Special European Council meeting of 23 April 2015, the leaders did explicitly support a "a wider European rescue operation in the Mediterranean" as well as "joint actions [...] with third countries to build capacities to fight against criminal networks" (Party of European Socialists, 2015a).35

35 The meeting was attended by prime ministers Matteo Renzi (Italy, PD), François Hollande (France, PS), Helle Thorning-Schmidt (Denmark, SD), Stefan Löfven (Sweden, SAP), and Joseph Muscat (Malta, LP), 
Nevertheless, there is limited evidence of ad hoc and bilateral transnational activities with a view to foster common positions on EUNAVFOR Med by the SPD in the Bundestag. In March 2015, two German MPs, together with the centre-left president of the standing committee for human rights in the Italian lower house, launched a GermanItalian parliamentary initiative to call for an EU mission on the Mediterranean Sea. That mission should have had at least the same "scope and standards" as the ceased, EUfunded, Italian search and rescue operation Mare Nostrum (Schwabe, Marazziti \& Heinrich, 2015). The declaration was launched one day ahead of the Special European Council meeting in April 2015. It was initially signed by 29 German and Italian MPs, but it was the intention of the initiators to rally "as many MPs as possible from all EU member states" behind the initiative (Schwabe \& Heinrich, 2015).

Moreover, and similar to the practice at the Greens, one interviewee mentioned that a group of ten to fifteen representatives of the socialist party family met at the various meetings of the IPC CFSP/CSDP. They discussed potential common perspectives on the draft conclusions of the conference and common views on amendments. They, however, also called these family meetings an "empty shell" and explained that little could be done at the IPC CFSP/CSDP. They saw this not just as the result of the absence of a fixed secretariat and fixed structures, but also of the draft conclusions being prepared by the Foreign Affairs committee of the European Parliament, which subsequently required unanimity to change (interview 15).

\section{The difficulties of establishing collective political strategies for ideological contestation}

Transnational party activities with a view to EUNAVFOR Med driven by the last resource dependency identified in the theoretical framework, collective political strategies, were limited for interviewees from all parties - and particularly so for those from the SPD. Only a few interviewees brought up examples of specific transnational strategies to contest operation EUNAVFOR Med beyond national borders. Several interviewees, however, commented on the potential normative (un)importance of such transnational strategies. At the same time, interviewees provided various explanations for the absence of actual transnational party activities to foster collective positions, as well as for the absence of an interest in such activities.

At the SPD, collective political strategies on EUNAVFOR Med of interviewees were particularly limited. One interviewee brought up an example of contestation of operation EUNAVFOR Med beyond national borders. Namely, they were informally approached by an Italian colleague to discuss the presence of NGO rescue ships on the Mediterranean Sea, as many of these ships are financed from Germany (interview 11).

as well as by the social democratic leaders in the Commission, the Parliament, and the PES. See https://www.pes.eu/en/news-events/news/detail/Prime-Ministers-agree-actions-needed-to-tacklemigrant-deaths/. 
Several interviewees stressed that more institutionalised transnational cooperation in security and defence would be important in the future (interviews 3, 5 and 11). In this perspective, the increasingly transnational character of European security and defence politics requires more intensive parliamentary cooperation - particularly in view of the situation that the EP has little to do with questions about defence. To interviewees, this also included using party contacts to raise the added value of the IPC CFSP/CSDP (interview 11), as well as moving towards common party family positions in the future (interviews 3 and 11). Such positions would also include a shared social democratic worldview that could serve as a basis for similar decisions across the EU (interview 11).

Other interviewees from the SPD, however, primarily argued that the position of social democratic sister parties in the EU were not important to them in view of operation EUNAVFOR Med (interviews 7 and 17). One interviewee explained that the SPD could and also did try to convince sister parties, but, as a party that did not do well in national elections, this was not very credible to social democratic parties elsewhere that held a majority (interview 7). Another interviewee discussed that common positions would only be important when a sister party is in government. A sister party in opposition could well be more focused on criticising the government about EUNAVFOR Med (interview 17).

To explain the absence of further attempts at transnational contestation of EUNAVFOR Med, interviewees often referred to substantial differences between the national interests of social democratic parliamentarians from across the EU (interviews 3, 7 and 11). That is, several interviewees from the SPD mentioned that transnational partisan activities were inhibited by the absence of a common social democratic view on the crisis in the Mediterranean and, accordingly, on operation EUNAVFOR Med. Some interviewees, for example, found exchanges with other social democratic MPs, also at the family meetings at the IPC CFSP/CSDP, difficult to deepen (interview 7 and 11). National differences had also made it very difficult to arrive at a common conclusion about the 'refugee crisis' at one of the meetings of the IPC (interview 7). Another interviewee observed that the role of party ideology was generally not as important in security and defence as in areas that come with explicit "social" questions. They found that national traditions and broad national consensus mattered more instead (interview 5).

Differences between the SPD and sister parties were perceived to be especially pronounced with MPs from several Central and Eastern European member states, such as from Poland and Hungary (interviews 3, 5 and 7). Viewpoints were seen to be more similar to, for example, the Dutch colleagues (interviews 3 and 11). One interviewee, for example, found discussions at the IPC with some social democratic colleagues from Eastern Europe 'disillusioning' (interview 3). Another interviewee signalled large differences between the policy preferences towards security and defence of Eastern European member states, like Poland, Latvia, and Lithuania, and Southern European member states, like Portugal and Spain (interview 3). 
Alterative explanations for the absence of further transnational activities by the SPD included various arguments about the structural organisation of cross-national contacts. The participation of parliamentarians at the IPC/CFSP fluctuates, not least due to electoral turnover (interviews 7 and 11). Moreover, armies are organised nationally and national parliaments have different rights concerning troop deployment. The latter complicated interaction (interviews 3 and 11), as did different parliamentary calendars (interviews 3 and 6). Moreover, relations with MEPs in the area defence are complicated by the absence of a mandate of MEPs to have a formal say in the area of security and defence (interviews 8 and 11) and by the resulting different organisational standings of the defence committees in the EP and the Bundestag (interviews 3 and 7). As one interviewee explained, the activities and rights of the EP's Subcommittee on Security and Defence (SEDE) are not congruent with those of the German defence committee, so that parliamentarians cannot exchange with one another on an equal footing. Parliamentarians both in Berlin and in Brussels hence act within their own "bubble" and MPs may simply argue that they do not need others (interview 3). Finally, one interview brought up that trips to inter-parliamentary conferences abroad are difficult to explain towards their constituency. Voters may think that such trips are just for fun, not least because the conference has no real decision-making capacity (interview 7).

The German Greens made some attempts to collectively steer negotiations with sister parties, albeit within the more low-profile IPC CFSP/CSDP. They attempted to influence the amendments to conclusions of the conference's working groups on migration and, ultimately, the final report of the IPC CFSP/CSDP (interview 1 and 14). The goal of the Greens was to include a more humanitarian perspective on the situation in the Mediterranean in the final conclusions of the conference, including a mention of the creation of legal and safe immigration routes to Europe (interview 1). The strategy to do this was to first reach agreement within the national delegation. After establishing common positions with green parliamentarians, other members of other delegations with similar views were approached. This process became easier after initial personal contacts were established (interview 14).

Beyond this, however, attempts to transnationally contest security and defence issues with sister parties in other national parliaments were said to be rare (interview 10). Interviewees did, however, provide examples of transnational contestation beyond the specific topic of operation EUNAVFOR Med. This included an occasional visit by a spokesperson on foreign policy from the Austrian green party to a working group session on general foreign policy issues (interview 10). There was also one example of close informal contact to a Swedish Green MEP about the topic of migration in general (interview 14). While the Greens did know about the position towards EUNAVFOR Med of other green parties in the EU and also considered these arguments of sister parties (interview 13 and 14), it was ultimately not considered to be very important that sister parties also voted in the same way (interview 1 and 13). That is, the vote about the 
mandate of the operation was really a decision of the Bundestag about the deployment of German armed forces (interviews 1 and 13).

The absence of further political cooperation may also be explained by the heterogeneity of the political organisation of the Greens across the EU. One interviewee found that green parties have declined in most European countries, with the exception of the Netherlands and Austria, or have suffered from internal fractures, such as in France. Hence, there are only a few 'strong' green parties in the EU that the German Greens could turn to (interview 10). Moreover, as a comparatively small party group in their own parliament, it was not always easy to attend conferences, because this requires a lot of work (interview 14). Another interviewee explained that the very extent of coordination of collective positions at the IPC CFSP/CSDP was small, given that only few Green representatives attended. Reflecting on the potential for more cooperation, they argued that transnational activities to steer decision making may become more important when another green party is in government (interview 1).

Indeed, with regard to the latter reflection, an interviewee from the Left brought up an example of an attempt to steer decision making elsewhere in the EU. They explained that the Left had started to develop cooperation with MPs in the Portuguese parliament of the radical left party Left Bloc (Bloco de Esquerda). The Left Bloc supported the Socialist minority government in Portugal at the time. The German Left gave advice about how to ask questions to the government, as well as about what questions to ask (interview 4). Moreover, the Left shared information it had about EUNAVFOR Med with sister parties in other EU member states to support opposition to the operation. This information was, for example, obtained through personal networks with NGOs. Particularly radical left parties in Spain, Italy, and Greece were interested in this information. Such exchanges occurred through the respective working groups in the Party of the European Left (interview 4).

Another interviewee at the Left provided an example of transnational ideological contestation through activist networks. They made use of the language service (Sprachendienst) of the Bundestag to translate their articles to English, to be able to subsequently share them on social media and with NGOs. This was done somewhat infrequently. While there was no collaboration with staff or parliamentarians of radical left parties in other national parliaments, the interviewee considered such collaboration to be potentially important (interview 2).

At the same time, substantial transnational contestation remained limited also at the Left. Interviewees responded that they made their decision about EUNAVFOR Med irrespective of the positions of sister parties (interview 12). They also found contestation of the operation most important to pursue with a view to the national government, rather than on a European level (interview 2). Any transnational activities indeed had to be translated to the national level, as this is where actual decisions were taken (interview 4). Moreover, the structures of individual Left MPs to have a say at the European level are limited, as are the topics that they can cover through these structures (interview 2). For 
example, the Left had previously attempted to foster transnational contestation through the network of the PEL, but these attempts had been very difficult. One explanation for this was the very small number of staff members at the PEL (interview 4). Moreover, in view of being a small opposition party, MPs may simply not have the time to engage in transnational interaction in view of procedures and workload in the Bundestag (interview 12). The transnational work of staff members may also be unpaid (interview 4).

\section{5 | Comparative analysis}

In this section, I analyse the findings about the transnational party activities of the SPD, the Left, and the Greens with a view to EUNAVFOR Med. I do so in two ways. First, I summarise how different resource dependencies have driven the transnational party activities of national parties in parliamentary office within the dossier of EUNAVFOR Med. This relates to the first overall research question of this dissertation about what drives the transnational party activities of national parties in the EU. Second, I compare the findings about transnational party activities across the cases of the SPD, the Left, and the Greens. This relates to the second overall question of this dissertation about the conditions under which national parties engage in transnational party activities.

\section{Motivations to engage in transnational party activities to seek, policy success}

With regard to the overall motivations of the parliamentary parties of the SPD, the Left, and the Greens to engage in transnational party activities with a view to military operation EUNAVFOR Med, three findings stand out.

First, transnational party activities of parties in parliamentary office are driven mostly by resource needs that result from the search for policy success within the national realm. They are especially useful to gather political expertise and to share subject-matter expertise. The aim of most transnational contacts with sister parties or with the political group in the European Parliament was to gather information or expertise that could be used either to formulate an opinion about the German military contribution to EUNAVFOR Med, or to scrutinise the national government about the execution of the operation. Transnational contacts to party actors beyond the Bundestag were most often a response to a need for political expertise about the positions of other decision makers about the military operation, such as that of other national parliaments and governments. When contacts concerned subject-matter expertise, this was mostly driven by a need to share or acquire information that originated from sources other than parliamentary or party actors.

Second, transnational party activities to seek policy success at the European level in the field of security and defence policy are relatively few, but certainly not non-existent. In terms of the motivation of individual actors, the absence of further activities at the European level can best be understood by the focus of parliamentary decision making on security and defence at the national level. Clearly, only the Bundestag has the right to make 
a decision about mandates for German troop deployments. This is why particularly in this area the work of parliamentarians and staff members is focused on the national level. With regard to EUNAVFOR Med, the parliamentary parties hence attributed little importance to transnational activities to foster collective positions or strategies to influence decision making beyond the Bundestag. There were, nevertheless, some transnational party activities that were driven by a desire to develop common positions and to influence negotiations outside of the national realm. For all three left-wing parties, such activities were primarily motivated by a desire to contest a perceived Europe-wide, conservative, right-wing response to the crisis in the Mediterranean Sea.

Third, some transnational party activities are primarily intended to obtain transorganisational legitimacy in the wider field of foreign and security policy. That is, beyond the resource dependencies related to policy-seeking behaviour with a view to operation EUNAVFOR Med discussed hitherto, some transnational party activities were motivated by a need to acquire trans-organisational legitimacy. Attending inter-parliamentary conferences or meetings, or transnational party meetings with sister parties, helped to develop and stabilise relationships. This included activities that did not involve any immediate exchange of resources, but that interviewees primarily perceived as 'symbolic' or as 'networking' (see also Peters, 2017). In this respect, interviewees mentioned that also contacts within the international parliamentary groups, including special meetings with the French parliament, were primarily symbolic and of a 'ritual' character (interviews 3 and 5).

\section{System-level factors that condition motivations to engage in transnational party activities to seek. policy success}

Table 17 summarises the findings of the case study on the transnational party activities with a view to EUNAVFOR Med specifically for the SPD, the Left, and the Greens. It reports on the overall level of importance that interviewees from each political party ascribed to transnational party activities to manage particular resource dependencies (see chapter 4, section 4.4). Although it may be that individual interviewees attributed somewhat more or less importance to transnational activities, generally, there were no big differences within the parliamentary parties.

On the basis of this comparison and the findings described in section 5.4, I can confirm the three (sets of) theoretical expectations about the conditions under which national parties engage in transnational party activities in EU affairs with a view to policyseeking. The case study, however, also leads to new insights with respect to each of these expectations.

First, the findings clearly confirm expectation (1.3) that opposition parties have more incentive to engage in transnational party activities than government parties. This is particularly so when it concerns activities to manage resource dependencies related to party goals at the national level. Yet it is also the case for collective transnational contestation of an EU decision at the European level after it has been taken. The findings show that opposition parties had more limited access to government information than 
government parties. They also had a stronger desire to acquire additional information both about the process of decision-making on EUNAVFOR Med and about the subjectmatter of the military operation. This confirms previous findings from literature on interparliamentary cooperation and the Europeanisation of political parties in the EU that opposition parties engage in transnational activities more often than government parties (e.g. Hefftler, 2015, p. 19; Johansson 1997, p. 214; Miklin, 2013, 23; compare Malang, 2019, p. 17).

Table 17 | Resource dependencies and the transnational party activities of the SPD, the Left and the Greens with a view to EUNAVFOR Med

\begin{tabular}{|c|c|c|}
\hline $\begin{array}{l}\text { Political party } \\
\text { (in parliament) }\end{array}$ & $\begin{array}{l}\text { Resource dependencies related to } \\
\text { party goals at the national level }\end{array}$ & $\begin{array}{l}\text { Resource dependencies related to } \\
\text { party goals at the European level }\end{array}$ \\
\hline SPD & $\begin{array}{l}\text { - Some importance attributed to } \\
\text { acquiring political expertise through } \\
\text { transnational party activities; } \\
\text { - No importance attributed to } \\
\text { acquiring subject-matter expertise } \\
\text { through transnational party activities. }\end{array}$ & $\begin{array}{l}\text { - Limited importance attributed to } \\
\text { developing collective political positions } \\
\text { through bilateral channels; } \\
\text { - No importance attributed to } \\
\text { facilitating collective political strategies. }\end{array}$ \\
\hline The Left & $\begin{array}{l}\text { - Substantial importance attributed } \\
\text { to sharing of subject-matter expertise } \\
\text { through transnational party activities; } \\
\text { - Some importance attributed } \\
\text { acquiring political expertise through } \\
\text { transnational party activities. }\end{array}$ & $\begin{array}{l}\text { - Some importance attributed to } \\
\text { aligning collective political positions, } \\
\text { - Some importance attributed to } \\
\text { facilitating collective political strategies } \\
\text { towards national governments } \\
\text { through multilateral and bilateral } \\
\text { channels. }\end{array}$ \\
\hline The Greens & $\begin{array}{l}\text { - Substantial importance attributed } \\
\text { to acquiring political expertise through } \\
\text { transnational party activities; } \\
\text { - Some importance attributed to } \\
\text { acquiring subject-matter expertise } \\
\text { through transnational party activities. }\end{array}$ & $\begin{array}{l}\text { - Some importance attributed to } \\
\text { developing collective political positions } \\
\text { through the IPC CFSP/CSDP; } \\
\text { - Some importance attributed to } \\
\text { facilitating collective political strategies } \\
\text { through the IPC CFSP/CSDP. }\end{array}$ \\
\hline
\end{tabular}

Importantly, however, the findings about the transnational party activities with a view to EUNAVFOR Med of the two opposition parties the Left and the Greens show that the 'opposition party' is not a unitary category. That is, the purpose of transnational party activities also depends on the domestic party strategy that a party pursues. In its fundamental opposition to EUNAVFOR Med, the Left focused its scrutiny mostly on the content of the operation, aiming to challenge the government through many technical questions. To do so, it faced a need for subject-matter expertise. For the Greens, scrutiny was more focused on the process of decision making, particularly at the start of the operation. Transnational party cooperation was used to gather information about the policy positions of various actors in the decision-making process. One explanation for these different strategies may be the existence of different policy goals. The Greens did 
not fundamentally oppose the idea of military operations and may have therefore been more focused on participating in the decision-making process. The Left did fundamentally oppose any military operation and may hence have been more focused on showing the wrongfulness of EUNAVFOR Med.

Second, the findings partially confirm the second set of expectations that (2.1) parties with many alternative networks or much in-house capacity to generate policyseeking resources have less incentive to engage in transnational party activities; and that (2.2) parties are more likely to engage in transnational party activities with sister parties that have relevant access to policy-seeking resources. With regard to the latter expectation (2.2), interviewees from the Greens explained that the absence of strong green parties in other EU member states inhibited further transnational party activities with a view to EUNAVFOR Med. The fact that the Left attributed special importance to coordinating with the Portuguese Left that supported the minority government also provides evidence to suggest that parties are particularly focused on those sister parties that are in - or, in this case, close to - government office.

With regard to the former expectation (2.1), on the one hand, the findings show that interviewees did not consider more in-house capacity to generate resources as an important factor that leads to fewer transnational party activities. By contrast, interviewees from the Left and the Greens stressed that it was not easy for a smaller party to engage in activities outside of the Bundestag, given more limited in-house resources in terms of time and staff (see also Vantaggiato, 2019).

On the other hand, parties did indeed mostly rely on existing networks that generate access to external resources. Particularly with a view to subject-matter expertise, interviewees at all three parties preferred to rely on actors within their own networks, be they the ministries, the media, or NGOs. Such personal contacts also reduce uncertainty. As one interviewee explained, parliamentarians require timely information and personal contacts facilitate such quick access to information (interview 17). Transnational party activities with a view to EUNAVFOR Med were likewise highly informal and mostly pursued through personal contacts. These contacts were strongest between the own national party group in the national parliament and in the European Parliament, both at the level of staff members and of parliamentarians (see also Miklin \& Crum, 2011).

Third, and finally, the findings confirm expectation (3) that parties are more likely to seek cooperation through multilateral channels when ideological coherence within their party family is strong, while they are more likely to rely on bilateral cooperation when ideological coherence is weak. The Greens and the Left, whose party families were shown to be more coherent based on CHES data about positions towards troop deployment, indeed cooperated through multilateral networks of cooperation. This included party family meetings at the IPC CFSP/CSDP and the Europarty. In turn, the SPD did not actively seek cooperation on EUNAVFOR Med through multilateral networks. More specifically, while interviewees attended multilateral meetings, contacts specifically on operation EUNAVFOR Med were pursued mostly on a bilateral and informal basis. 
Confirming the CHES data, interviewees from the SPD perceived strong ideological differences on defence within their party families, most importantly with the EastEuropean counterparts (see also Schuster and Maier 2016). They also explained that this particularly inhibited collective political positions and strategies for political contestation within the party family.

These findings moderate the argument of Miklin (2013) about the relation between ideological coherence and transnational party activities. He argues that parties with an "ideological profile" that allows them to integrate in a "European party network" engage more intensively in transnational party activities than parties that are non-affiliated to institutional frameworks for cooperation (p. 23). While this may be true, the current findings also show that parties that are well-integrated in a European party network may still not actually engage in transnational activities when there are different positions within the party family on a particular issue or policy area. In other words, the degree to which parties engage in transnational party activities does not depend on overall ideological coherence in the party family, but on issue-specific coherence.

On a critical note, on the basis of the findings about the transnational party activities of the SPD, the Left and the Greens with a view to operation EUNAVFOR Med alone, any weighing of the importance of one system-level factor vis-à-vis another is tentative. In other words, given the small number of cases and the limited variation between them, I can provide no conclusive answer to the questions of how the various system-level factors interact with each other and of the extent to which the presence or absence of transnational party activities can best be understood by one factor or another. For example, interviewees from the SPD may not have engaged in transnational activities to seek policy success at the European level because of major differences in policy positions with sister parties. Yet given that the SPD was also in government, it is not likely that they would have engaged in transnational activities if common viewpoints had existed. 



\section{Chapter 6}

\section{Transnational party activities in the context of campaigning for national and European elections}

In this chapter, I explore the transnational activities of the SPD, the Left and the Greens with a view to campaigning for national and European elections. I focus on preparations for the European elections (Europawab) of 2014 and 2019 and the federal elections (Bundestagswab) of 2013 and 2017. To contextualise the findings and to beef up the evidence on the patterns of cooperation, the study also involves some experiences with transnational cooperation on campaigns of earlier elections. Whereas the previous chapter focused on transnational party activities with a view to policy-seeking of the parties in parliamentary office, the current chapter focuses on the vote and office-seeking behaviour of the parties in central office.

The national and European elections after the first decade of the 2000 s provide a rich context to study transnational party activities of national parties on the left of the political spectrum. First, the growth of Eurosceptic parties on the radical right presented political parties at the more pro-European left with a political challenge. Populist radical right (PRR) parties obtained parliamentary office in about half of the EU member states (Mudde, 2016, p. 297-298) and particularly the 2019 European elections saw the entry of many radical right parties in the European Parliament. With some relative delay, also the German PRR party AfD found its way into the Bundestag (see e.g. Hansen \& Olsen 2018). Second, especially since the financial and economic crisis of 2008, social democratic parties on the centre-left in Europe have suffered an electoral decline. So did not least the German SPD (see e.g. Manwaring \& Kennedy, 2018, p. 5). Third, and on a different note, since the 2014 European elections, Europarties have elected lead candidates to run for Commission President, using a provision of the Lisbon Treaty that establishes a link between the outcome of the European elections and the proposal for a new Commission President by the European Council. 
Indeed, despite the infamous 'second-order effect' - whereby voters use elections to the European Parliament to express dissatisfaction with national government parties (Reif \& Schmitt, 1980; Hix \& Marsh, 2011; 2007) - research shows that the national and European level are interlinked in the context of elections. When politicisation of European issues is high, voters do consider the EU positions of political parties in European elections (Hobolt \& Spoon, 2012). Voters also punish parties without a clear stance towards the EU (Ferrara \& Weishaupt, 2004). Moreover, campaigning by the lead candidates of Europarties can increase voter turnout (Schmitt, Hobolt \& Popa, 2015). And even in national elections, EU issues matter when partisan conflict and salience among voters are high (De Vries, 2007).

This multi-level political system (see Swenden \& Maddens, 2009) presents national parties with strategic opportunities to cooperate with sister parties in view of both national and European election campaigns (e.g. Böhmelt, Ezrow, Lehrer \& Ward, 2016; Hertner, 2011b; Gagatek, 2009). Nevertheless, there is very little research that studies the activities of national political parties aimed at fostering electoral success across borders and levels (for an exception, see Dolowitz, Greenwold \& Marsh, 1999). Under what conditions do parties of the same party family actively seek to support each other's campaigns in national and European elections? And what is the role of Europarties in facilitating this?

The chapter follows a structure that is similar to chapter 5. The first section returns to the broad analytical framework of chapter 1, setting the scene with a discussion of the potential avenues for transnational party activities on elections specifically. Section two specifies the theoretical argument of chapter 3 and puts forward expectations about transnational party activities with a view to national and European elections. Section three provides background information to the election campaigns that are part of this inquiry. Section four reports on the findings about the transnational activities of the German SPD, the Left, and the Greens with a view to national and European election campaigns. In the final section of the chapter, I compare the findings in view of the resourcedependence perspective on transnational party activities in the EU.

\section{1 | Potential avenues for transnational party activities in campaigns for national and European elections}

A basic, but key, observation in the scholarly literature about the professionalisation of election campaigns is that strategies for election campaigns, as well as practices to run campaigns, 'travel' across borders (e.g. Böhmelt et al., 2016; Negrine, Holtz-Bacha, Mancini \& Papathanassopoulos, 2007). That is, campaign strategies show similarities across countries. To quote the observation that Swanson and Mancini (1996) make already in the 1990s, "many of the recent changes in election campaigning share common themes despite great differences in the political cultures, histories and institutions of the countries in which they have occurred" (p. 2). The United States (US) is often considered 
as the inspiration for and the source of such changes, as it is the primary example of professional campaigning (on the debate about this 'Americanisation', see e.g. Baines, Scheucher \& Plasser, 2001).

In brief, the development of more professional campaigns can be described as a change from campaigns that are "short, decentralised, and dependent on physical [wo]manpower" to campaigns that are long-term or even permanent and crucially rely on the input of professional campaigners (De Vreese, 2009, p. 8; see also Gibson \& Römmele, 2001). Parties also spend more money in a professional campaign - such as on media publicity - increasingly rely on communication technologies, and target individual voters (De Vreese, 2009, p. 8).

Such developments are accompanied by changes in the internal organisations of political parties. In Western Europe most notably, national parties have generally increased spending on staff at the level of the central party office. They have also gradually created an office around the party leader with "handpicked campaign, media and policy specialists" and have increasingly relied on "specialist campaign agencies and political consultants" (Farrell \& Webb, 2002, p. 119). Parties thus also increasingly employ professional campaign staff. These structural and strategic changes can be financed mostly by large parties (see e.g. Tenscher, 2013, p. 251).

Campaigns for European elections do not seem to show the same level of professionalisation as campaigns for national elections. Arguably, this is the result of their 'second-order nature' (e.g. De Vreese, 2009): elections to the European Parliament are less important to national parties, because national parties find that there is less at stake (Reif \& Schmitt, 1980). Nevertheless, there is some evidence to suggest that political parties have professionalised their European election campaigns more rapidly in recent years (Tenscher \& Mykkänen, 2014, p. 30-31). For example, various studies show that parties extensively rely on online campaign strategies also in European elections, which is one element of professional campaigning (e.g. Lorenzo Rodriguez \& Garmendia Madariaga, 2016; Nulty, Theocharis, Popa, Parnet \& Benoit, 2016).

Against this background of increasingly professional and technically complex election campaigns, national parties can behave as transnational actors both in the context of national and of European elections. With regard to the analytical framework presented in chapter 1, two potential avenues for transnational party activities in the European Union stand out. These are the Europarties and the party organisational structures of national parties themselves. It should, however, be noted that EP political groups and European party foundations may also take up a small role in European election campaigns, even though they are prohibited from financing any electoral campaigns. Political groups may, for example, provide information about their parliamentary work as input to the campaign of Europarties. And foundations may take up an advisory role in formulating Europarty manifestos (Gagatek \& Van Hecke, 2014, p. 100).

First, Europarties can play a role in fostering transnational party activities on election campaigns. This role plays out differently in the context of national elections, on 
the one hand, and European elections, on the other hand. Most importantly, Europarties are prohibited from funding campaigns for national elections and referenda. Although it would hence seem that they are not relevant for member parties in view of national elections, Europarties may still perform a role in establishing links between sister parties to facilitate the exchange of best practices. For example, Europarties have organised meetings between national staff members responsible for campaigning in view of their European election campaigns (see e.g. Hertner, 2011b). Moreover, practices of Europarty campaigning may transfer to the national election campaigns of member parties (Tenscher et al., 2012, p. 160), particularly when member parties second campaigners to the team of their Europarty.

International party organisations, such as the Socialist International and the Centrist Democrat International, can likewise play a role in facilitating transnational exchange between national parties about election campaign strategies. For example, the social democratic Progressive Alliance, created as an alternative to the Socialist International in 2013, has organised international campaign forums and seminars to discuss particular campaign strategies (Progressive Alliance, 2018, p. 62). International party organisations may also facilitate an exchange of knowledge about how particular policy positions can be beneficial in campaigns (see Krook, 2009, p. 24-25, 136 and 167).

In European elections, Europarties can finance campaigns, and can also develop manifestos together with their member parties. While the practice of Europarty manifestos is long-standing, the role of Europarties as campaign organisations is relatively recent and restricted. That is, Europarties only obtained the ability to use funds for campaigns in elections to the European Parliament with the 2007 regulation on Europarties (Regulation (EC) No 1524/2007). The initial regulation of 2003 that formally recognised Europarties still prohibited this (Regulation (EC) No 2004/2003). Importantly, however, the 2007 regulation does prohibit Europarties from directly or indirectly financing the European election campaigns of national parties (art. 8).

Since they were granted the ability to spend their budget on election campaigns, Europarties have enhanced their "role as campaigners" (Hertner, 2011b, p. 344). They have increased their visibility, for example through online campaigning (Gagatek, 2009, p. 69). In the European elections of 2014 and 2019, several Europarties also selected lead candidates to run for the position of President of the European Commission. This presented them with an opportunity to run transnational campaigns based on the personality of the so-called 'Spitzenkandidaten'. Although the visibility of the Spitzenkandidaten to voters has remained limited, "the lead candidates did make efforts to run a campaign which was distinctly European in its outlook", for example through televised 'Presidential' debates (Hobolt, 2014, p. 1534).

Because Europarties do not have their own transnational lists, it is unavoidable that they work with national parties in the organisation of a European campaign. Joint activities are allowed and are implicitly recognised in the 2014 regulation on Europarties (Wolfs, 2017, p. 10-11). The regulation specifies that financial statements should include 
"evidence of the expenditure incurred by the European political parties" for any activities "implemented [...] jointly with national political parties" (Regulation (EU, Euratom) No 1141/2014, art. 23 (2)). Europarties must hence show that they are genuinely involved in the joined event. This is not only difficult to do, but also difficult to assess retrospectively (p. 10-11). Moreover, national laws on elections campaigns can further complicate the ability of Europarties to conduct campaign activities (OSCE, 2009, p. 8).

Second, national parties can rely on organisational structures of their own as an avenue to transnational party activities. They can, for example, temporarily second expert staff working on election campaigns to serve an advisory role for a sister party abroad. They can also bring in such staff from sister parties. This may lead to the development of personal transnational relationships and networks, facilitating further exchange. One example of this is an exchange between the British Labour Party and the US Democrats in the 1990s, during which one of the main Labour strategists was "clearly influenced by his experiences in the Clinton campaign of 1992 and the contacts he made during his time in America" (Dolowitz et al. (1997, p. 727). Such exchanges of personnel between sister parties have also taken place in more recent years (Böhmelt et al. 2016, p. 397-398).

\subsection{What drives and what conditions transnational party activities in the context of national and European election campaigns?}

To explore the transnational activities of the SPD, the Left and the Greens, this chapter focusses on the resource dependencies of national parties in the EU that are related to the party goals of vote and office-seeking. These are presented and discussed in chapter 3. Table 18 once more presents the resource dependencies related to seeking electoral success and seeking the benefits of office at the national and European level respectively.

\section{Expectations about transnational party activities in national and European elections}

Beyond empirically exploring to what extent the identified resource dependencies drive transnational party activities with a view to election campaigns, the current chapter also explores the expectations about what system-level factors condition the transnational activities of the SPD, the Left, and the Greens. Chapter 3 sets out three sets of expectations about transnational party activities to seek the benefits of office and electoral success. These are:

\section{Position in the national political system}

(1.1) Parties that face a changing electorate have more incentive to engage in transnational party activities (with a view to vote-seeking);

(1.2) Parties that seek to obtain government office after a period of being in opposition have more incentive to engage in transnational party activities (with a view to officeseeking). 
Table 18 | Vote and office-seeking and resulting resource dependencies between parties at the national and EU level $\begin{array}{lll}\text { Party goals } & \begin{array}{l}\text { Resource dependencies related to party } \\ \text { goals at the national level }\end{array} & \begin{array}{l}\text { Resource dependencies related to party } \\ \text { goals at the European level }\end{array}\end{array}$

\begin{tabular}{|c|c|c|}
\hline $\begin{array}{l}\text { Electoral } \\
\text { success } \\
\text { (vote- } \\
\text { seeking) }\end{array}$ & $\begin{array}{l}\text { - Electoral positions input to the } \\
\text { national manifesto for elections or } \\
\text { positions to use in national debates } \\
\text { (Böhmelt et al., 2016; Dolowitz et } \\
\text { al., 1999; Külahci, 2010; Van Haute, } \\
\text { 2016a) } \\
\text { - Campaign expertise knowledge about } \\
\text { effective party campaigning } \\
\text { (Dolowitz et al., 1999) }\end{array}$ & $\begin{array}{l}\text { - Collective electoral positions common } \\
\text { election manifesto and common } \\
\text { positions (e.g. Bressanelli, 2013; } \\
\text { Külahci, 2010) } \\
\text { - Collective campaign strategies common } \\
\text { election campaign and lead candidates } \\
\text { (e.g. Gagatek, 2009; Hertner, 2011b; } \\
\text { Hobolt, 2014) }\end{array}$ \\
\hline $\begin{array}{l}\text { Benefits of } \\
\text { office } \\
\text { (office- } \\
\text { seeking) }\end{array}$ & $\begin{array}{l}\text { Public legitimacy public perception as } \\
\text { a legitimate government or } \\
\text { opposition party (McDonnell \& } \\
\text { Werner 2017; Poguntke et al., 2007; } \\
\text { Startin \& Brack, 2016) }\end{array}$ & $\begin{array}{l}\text { - Collective access to parliamentary and party } \\
\text { resources* acceptance as a member of a } \\
\text { party group in the European } \\
\text { Parliament and European political } \\
\text { party (Bressanelli, 2012; Whitaker \& } \\
\text { Lynch, 2014) }\end{array}$ \\
\hline
\end{tabular}

Trans-organisational legitimacy to maintain a "coalition of support" and access to resources (Pfeffer \& Salancik, 2003[1978], p. 24-27)

*Note that this resource was not mentioned as an important resource to be acquired from external actors by the German parties in the case of national and European elections between 2014 and 2019. It was therefore dropped from further investigation (see chapter 4, section 4.2).

\section{Existence of (alternative) routes to obtain resources}

(2.1) Parties with many alternative networks or much in-house capacity to generate vote or office-seeking resources have less incentive to engage in transnational party activities;

(2.2) Parties are more likely to engage in transnational party activities with successful vote or office-seeking sister parties.

\section{Ideological coherence of the party family}

(3) Parties are more likely to seek cooperation through multilateral channels when ideological coherence within their party family is strong, while they are more likely to rely on bilateral cooperation when ideological coherence is weak.

The overarching expectations with regard to the transnational party activities of the SPD, the Greens and the Left are discussed in chapter 3 already, and further substantiated in chapter 4, section 4.3. There are, however, two important additions to this in light of the Bundestagswablen and Europawablen between 2013 and 2019.

First, with regard to the aspect of in-house capacity to generate vote or officeseeking resources, figure 12 contains data on the annual spending on election campaigns 
of the three German parties under study. It shows that there is substantial variation between the annual campaign spending specifically of the large SPD, and the smaller Greens and Left. At the same time, there is little variation in the share of total expenditures that parties spend on campaigns - although the Greens generally spend a slightly higher share of their total expenditures than the Left and the SPD.

Figure 12 | Annual spending in euros (millions) on campaigns SPD, the Left and the Greens from 2002-2017

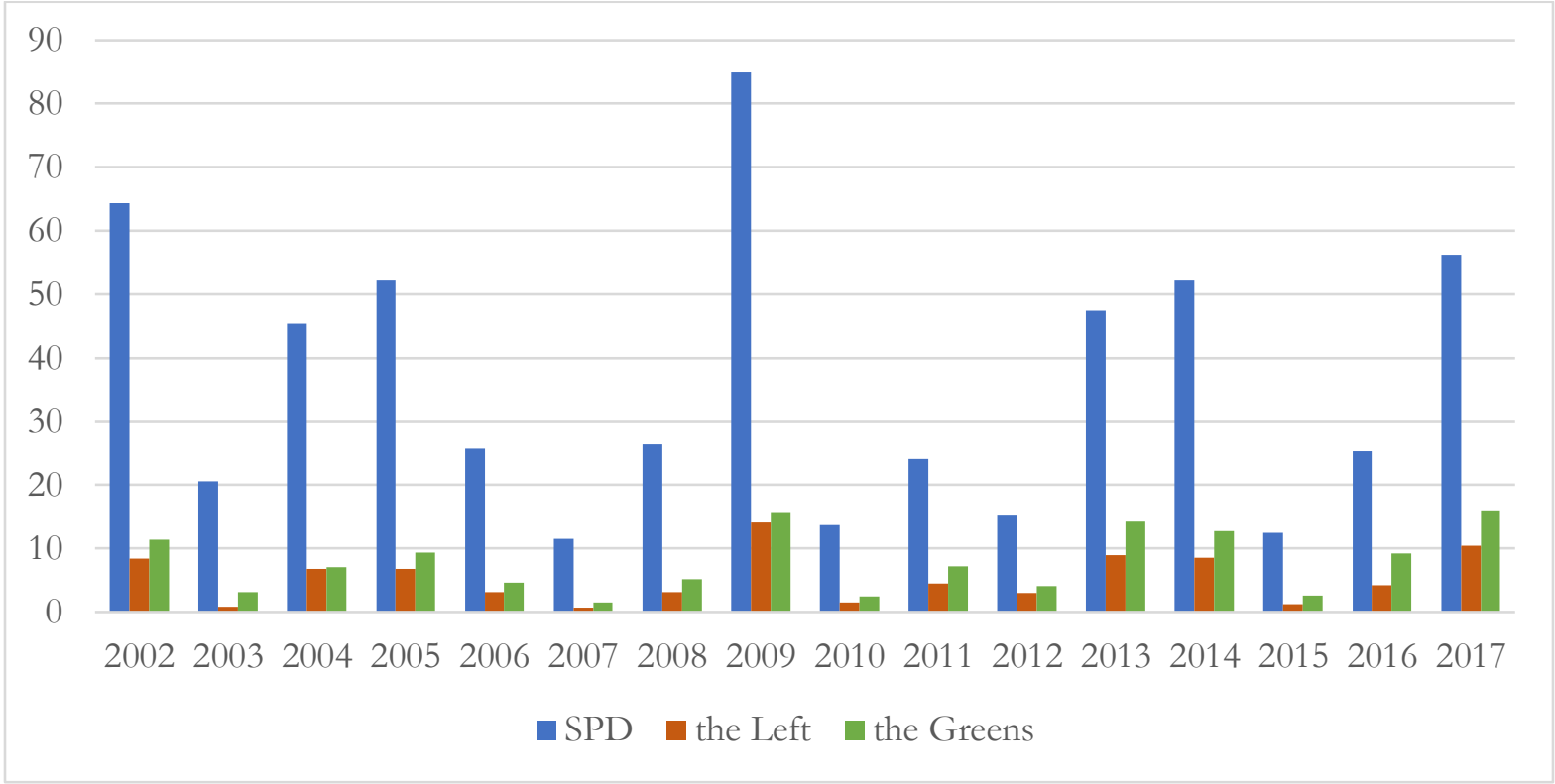

Data from the statements of accounts (Rechenschaftsberichten), available via http://pdok.bundestag.de. Data on 2018 was not available at the time this research was conducted. National federal elections took place in 2002, 2005, 2009, 2013 and 2017. European elections took place in 2004, 2009 and 2014. The graph does not display the annual campaign spending of the WASG, which merged with the Left in 2007.

The graph suggests that, at least financially, the three parties did not run permanent campaigns (Gibson \& Römmele, 2001). Rather, campaign spending substantially increases just before and during election years. It is difficult to judge if campaign spending is lower for European than for national elections. This seems to be the case, for example for the 2004 European elections compared to the 2002 and 2005 national elections, but not for the spending of the SPD during the 2014 elections compared to the 2013 national elections. The year 2009 was an extraordinary election years (Superwabljabr) as there were both national and European elections.

All in all, with a view to expectation (2.1), this data supports the general expectation formulated in chapter 3. The SPD has fewer incentives to engage in transnational party activities than the Left and the Greens, as it has more in-house resources for election campaigning.

Second, with regard to expectation (3) about ideological coherence, previous research suggests that national parties debate and contest the EU mostly in terms of their attitudes in favour or against European integration during election campaigns, rather than in terms of their left/right stance (e.g. Hobolt \& Spoon, 2012; Kriesi et al., 2006; Nulty et 
al., 2016). This may not matter much for transnational party activities with a view to national election campaigns, as party positions towards the EU are usually of little relevance during national elections (but see De Vries, 2007).36 It may, however, have implications for transnational party activities with a view to European election campaigns. That is, if the member parties of a Europarty have very diverging standpoints on the direction of European integration, it would be difficult for them to develop collective positions and strategies within the party family.

Figure 13 | Distribution of positions towards EU integration of the green, radical left and socialist EU party families, 2014

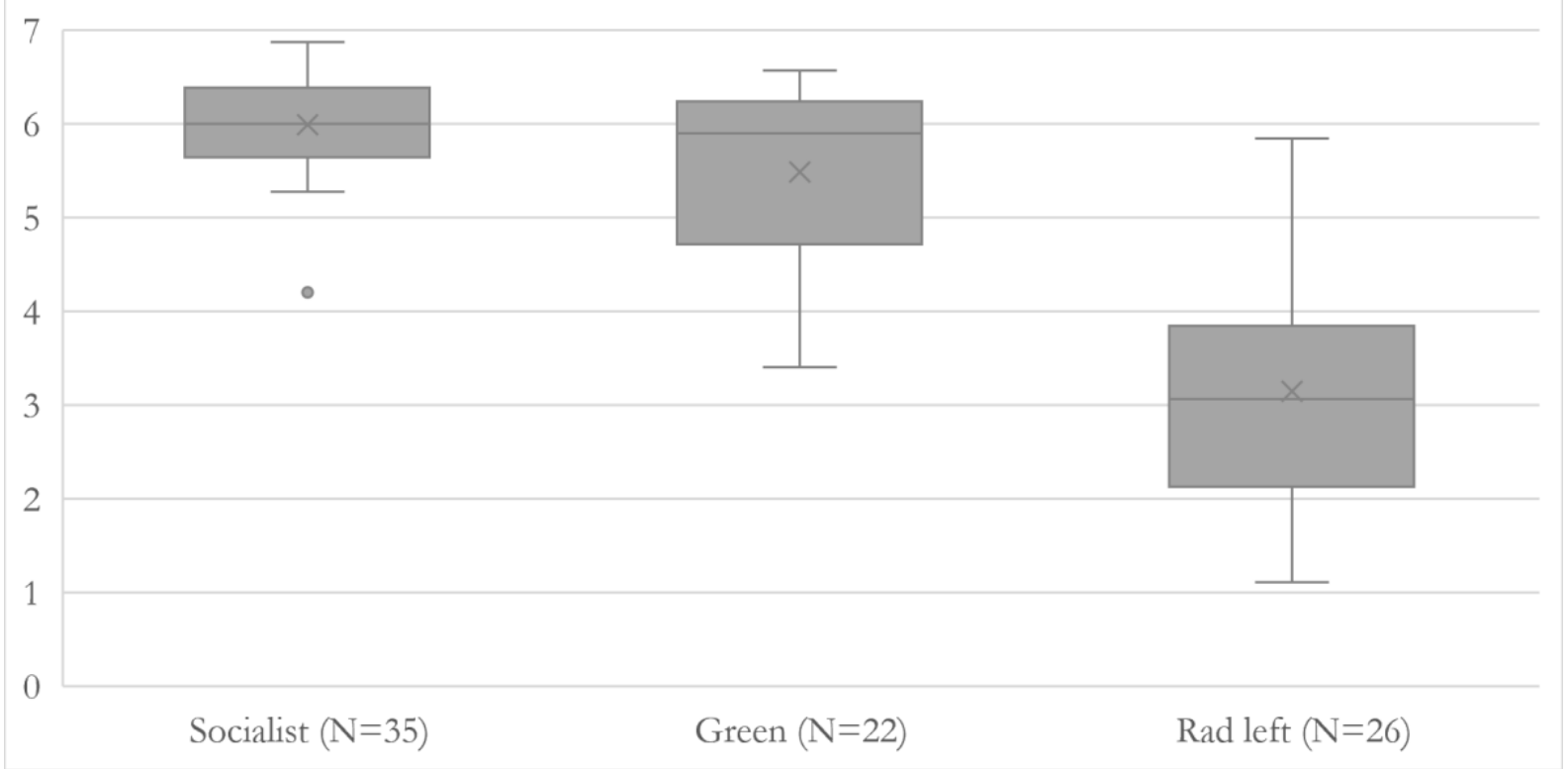

Source: 2014 CHES (Polk et al., 2017) and 1999-2014 CHES trend file (Bakeker et al., 2015).

Note: The scale European integration runs from 0 (strongly opposed) to 7 (strongly in favour). None of the indicated outliers are major parties in the European Parliament or parties from large EU member states. For further information on the data, see section 4.2 in chapter 4.

In this respect, figure 13 shows the box plots for the distribution of positions towards EU integration of the socialist, green, and radical left party families in the EU. The socialist family is most coherent when it comes to the positions of its parties towards European integration. The range of positions is smaller, and the population standard deviation of the socialist parties in the EU is also lower (0.519) than that of the green (0.939) and radical left (1.161) parties. The outlier towards less support for European integration in the socialist party family is the Latvian SDPS. In the radical left family, the French PRG and the Croatian HL-SR lean towards comparatively more support, while in the Green family, the Portuguese MPT and the Dutch PvdD lean towards comparatively less support.

36 For transnational party activities with a view to national election campaigns, the ideological positions of sister parties on the left/right or GAL/TAN scale are probably more important. These are reported in figure 6 of chapter 4, section 4.3, and not repeated here. 
Hence, with regard to expectation (3), this data implies that the Left is less likely to cooperate on a European election campaign through the multilateral framework of the Europarty than the SPD and the Greens.

\section{3 | The German Bundestagswahlen and Europawahlen between 2013 and 2019}

The German elections between 2013 and 2019 were characterised by two main shifts. These were an increasing fragmentation of the electorate and party system, and declining electoral support of the SPD. Historically, both shifts can partially be attributed to the welfare reforms of SPD Chancellor Gerhard Schröder between 1998 and 2005. The reforms remained unpopular with the SPD's electorate and led to a split by leading WestGerman SPD politicians. This ultimately resulted in the creation of the Left in 2007, a party that remained an important electoral competitor of the SPD (Decker, 2014; Dostal, 2017). In addition, the two shifts can be attributed to the various so-called 'Grand Coalitions' (GroKo) between the SPD and the CDU/CSU under Merkel's Chancellorship. The historically unique phenomenon in the German context of the GroKo arguably "pushed voters to other parties" (Poguntke, 2019, p. 71).

The division of seats in the 18th Bundestag did not reflect the changing party system yet (see table 19). As a result of the 5\% minimum vote threshold, the left-wing parties SPD, the Left, and the Greens obtained a majority of seats without having obtained a majority of votes (Decker, 2014, p. 20). The SPD, which had been in opposition in the preceding parliamentary term, won a few seats. The party, however, only made up a small part of the major losses the party had incurred in the 2009 elections. The Left and the Greens lost some seats. Indeed, the 2013 elections were a challenge to the Left, as the party had incurred important losses in preceding state elections (Faas, 2015, p. 240). The CDU/CSU was by far most successful in the 2013 Bundestagswabl and almost won an absolute parliamentary majority. Yet its junior coalition partner Freie Demokratische Partei (FDP) barely missed the minimum threshold. The newly founded right-wing populist party AfD likewise just failed to enter parliament. The result of the 2013 elections was the conclusion of another GroKo.

After the 2017 elections, an increasing fragmentation of the electorate led to a different division of seats in the 19th Bundestag. The 2017 Bundestagswabl was characterised by large losses of the two government parties CDU/CSU and SPD and by the success of the AfD. The latter party entered the Bundestag as the largest opposition party and also de FDP re-entered the parliament. For the first time, then, the Bundestag hosted six party groups. The Left and Greens made small gains. After negotiations for a so-called Jamaica coalition between the FDP, Greens, and CDU/CSU failed, another GroKo was installed.

The campaigns for the 2013 and 2017 Bundestagswablen were both dominated by the political issues surrounding the Chancellorship of Merkel. Merkel was highly popular during the 2013 election campaign. This can be understood by her handling of the 
Eurozone crisis and the economic upturn in Germany at the time. Moreover, Merkel moved towards the political centre on matters that the left-wing parties traditionally politicised in their election campaigns, including on the welfare state and climate. During the campaign, the left-wing parties could thus hardly mobilise voters on these matters (Decker, 2014, p. 22; Faas, 2015, p. 239-240). By contrast, in the 2017 campaign, the highly political issue of the refugee and migration 'crisis' dominated the political debate (Dostal, 2017, p. 591-596). Most importantly, dissatisfaction about the migration policy of Merkel was the prime cause for the success of the AfD in the 2017 Bundestagswabl (Hansen \& Olsen, 2019).

The major shifts in the German domestic political constellations also provide the context for the Europawablen. That is, the 2014 and 2019 European elections were arguably more significant to the German parties compared to previous editions, as they were an opportunity for parties to "(re)shape their distinctive profiles" (Möller, 2019). Moreover, EU affairs also became more politicised, and the 2014 European elections for the first time saw the campaigns of European Spitzenkandidaten. Nevertheless, compared to the election campaigns for the Bundestagswablen, the campaigns for the Europawablen remained "low-key" (Holtz-Bacha, 2019, p. 37).

Indeed, the German campaign in the 2014 Europwahl was called "uneventful and uninspiring", not least because of the few EU issues on the agenda (Niedermayer, 2014, p. 533). Such issues did include the crisis in Ukraine that had started in 2013 and access to German welfare benefits for workers from newly acceded EU countries (p. 531-532). The most striking result of the 2014 elections to the European Parliament in Germany was the success of the SPD, which obtained a higher vote share than in the 2013 Bundestagswabl. Arguably, Martin Schulz, who ran both as national and European Spitzenkandidat, had a mobilising effect on the electorate of the SPD. The SPD had also been domestically successful in realising pension reforms (p. 539).

In the 2019 Europawabl, however, the coalition parties CDU/CSU and SPD incurred major losses, as had been the case in the 2017 Bundestagswabl. Both parties obtained the lowest nation-wide results in their histories. By contrast, the Greens ran a highly successful campaign. In the context of several environmental scandals, as well as of the school strikes for the climate that became popular by late 2018, the Europawahl was called a 'climate election'. Another important issue in the campaign was the rise of the right-wing populist party AfD and several parties mobilised voters against the AfD (Holtz-Bacha, 2019). Ultimately, the Greens overtook the position of the SPD as the leading party on the left of the political spectrum, which was a "watershed in the development of the German party system” (Poguntke, 2019, p. 71). 
Table 19 | Vote shares and lead candidates in national and European elections in Germany (2013-2019)

\begin{tabular}{|c|c|c|c|}
\hline & & 2013 Bundestagswahl & 2017 Bundestagswahl \\
\hline Election date & & 22 September 2013 & 24 September 2017 \\
\hline \multirow{2}{*}{ Vote share } & SPD & $25.7 \%$ & $20.5 \%$ \\
\hline & the Left & $8.6 \%$ & $9.2 \%$ \\
\hline \multirow[t]{3}{*}{$\%$ Loss or gain } & SPD & $+2.7 \%$ & $-5.2 \%$ \\
\hline & the Left & $-3.3 \%$ & $+0.6 \%$ \\
\hline & he Greens & $-2.3 \%$ & $+0.5 \%$ \\
\hline National lead candidates & he Greens & Jürgen Trittin \& Katrin Göring-Eckhardt & Katrin Göring-Eckhardt \& Cem Özdemir \\
\hline \multirow[t]{4}{*}{ Party status preceding legislative ter } & $\mathrm{m} \quad \mathrm{SPD}$ & Opposition & Junior government party \\
\hline & the Left & Opposition & Opposition \\
\hline & he Greens & Opposition & Opposition \\
\hline & & 2014 Europawahl & 2019 Europawahl \\
\hline Election date & & 25 May 2014 & 26 May 2019 \\
\hline \multirow{2}{*}{$\%$ Loss or gain } & the Left & $-0.1 \%$ & $-1.9 \%$ \\
\hline & he Greens & $-1.4 \%$ & $+9.8 \%$ \\
\hline \multirow{3}{*}{ National lead candidates } & SPD & Martin Schulz & Katarina Barley \& Udo Bullmann \\
\hline & the Left & Gabi Zimmer & Özlem Demirel \& Martin Schirdewan \\
\hline & he Greens & Rebecca Harms \& Sven Giegold & Ska Keller \& Sven Giegold \\
\hline \multirow[t]{3}{*}{ European lead candidates } & SPD & Martin Schulz & Frans Timmermans (PvdA, the Netherlands) \\
\hline & the Left & Alexis Tsipras (Syriza, Greece) & $\begin{array}{l}\text { Violeta Tomič (Levica, Slovenia) \& Nico Cué (trade } \\
\text { union, Belgium) }\end{array}$ \\
\hline & he Greens & Ska Keller \& José Bové (EELV, France) & Ska Keller \& Bas Eickhout (GreenLeft, the Netherlands) \\
\hline
\end{tabular}

\footnotetext{
Source: own research and data from the ParlGov database (Döring \& Manow, 2018).
} 


\subsection{Transnational party activities on national and European campaigns}

\section{The limited use of electoral positions for national party manifestos in European elections}

The first resource dependency identified in the theoretical framework to drive transnational party activities with a view to vote-seeking is that of electoral positions. Yet the party headquarters of the SPD, the Left, and the Greens all had substantial own party resources to formulate national manifestos both for the 2013 and 2017 Bundestagswablen, and for the 2014 and 2019 Europawablen. Hence, at all three parties, input in terms of positions from sister parties or the Europarty for the own party manifesto, let alone for national debates, was not considered relevant. This was particularly so with a view to national elections. With respect to European elections, interviewees from the SPD and the Greens did attribute limited importance to the positions of their Europarties as input for their own positions - albeit to different degrees.

The various party manifestos for the 2013 and 2017 Bundestagswablen, as well as for the 2014 and 2019 Europawablen, contained only few explicit references to specific positions of the respective Europarties of the SPD, the Left and the Greens.37 The SPD referred to some achievements of the social democratic party family in its election manifestos. These included references to a social democratic initiative against youth unemployment in its 2014 Europawabl manifesto (Sozialdemokratische Partei Deutschlands, 2014a, p. 7; see also Party of European Socialists, 2014a, p. 3) and to preparations for a Financial Transaction Tax achieved through "social democratic pressure in Europe" in the 2013 Bundestagswabl and 2019 Europawabl manifestos (2013a, p. 103; 2019, p. 14). By contrast, for the 1989, 1994, and 1999 Europawablen, the SPD had integrally adopted a German translation of the PES programme.38

Interviewees at the SPD confirmed that the party did not find the positions of sister parties or the PES very important for to the positions of the SPD during Bundestagswablen or Europawablen (interview 27). In view of the 2019 Europawabl, one interviewee, for example, remarked that it was the aim of the SPD to write a party manifesto that would not contradict that of the PES (interview 29). Another interviewee believed that the SPD did make sure that the two manifestos were compatible and that there were some resonances between them (interview 34). For the 2019 Europawabl, this was facilitated by the early conclusion of the PES manifesto, as well as by having the same SPD staff member coordinate both the PES and the SPD manifesto. More importantly, the preparation of the PES manifesto was said to have presented an instrument to launch a broader participatory process within the SPD. That is, the preparation and conclusion

37 I searched the election manifestos for the keywords Familie, Parteienfamilie, schwester, sozial-demokratische, grune, linke, zusammen mit, gemeinsam, unser(e), europäischer Ebene, EU-Ebene, Fraktion, Parlament, EU-Parlament, Europaparlament, EGP, SPE, EL.

38 See the website of the Friedriech Ebert Stiftung for the archive of the SPD manifestos for national and European elections: https://www.fes.de/bibliothek/grundsatz-regierungs-und-wahlprogramme-der-spd1949-heute. 
of the PES manifesto was used to "infiltrate" the own party organisation with the topic of the European elections (interview 29).

The Greens added a German translation of the preamble of the common EGP manifesto to their own manifesto for the 2014 Europawahl (Bündnis 90/Die Grünen, 2014, p. 121-127), but did not do so again in view of the 2019 European elections. The 2019 manifesto made a few explicit references to achievements of the green party family. This, for example, included pressure from the party group in the European Parliament that resulted in a Commission proposal about protection of whistle-blowers (2019, p. 83; see also European Green Party, 2018b, p. 2). There were, however, no clear references to positions of the EGP in national election manifestos for the 2013 and 2017 Bundestagswablen.

One interviewee confirmed that the Greens found the EGP manifesto relevant to the content of the national party manifesto for the Europawablen. In preparation of the 2019 Europawabl, for example, the Greens emphasized several priorities of the EGP manifesto also in their own manifesto and campaign. Amongst other issues, this included a ban on the use of toxic pesticides, European legislation on the minimum wage, and the ability to control the spending of European funds in states that do not comply to the EU's standards of democracy (interview 25). Indeed, these issues were three of the twelve priorities of the EGP (European Green Party, 2018a, p. 2-3; European Green Party, 2018b, p. 4-5, 10-11) and they were also discussed as key (sub)issues in the manifesto of the Greens (Bündnis 90/Die Grünen, 2018, p. 39, 75-76, 80-85).

The Left made some explicit references to policy proposals that it would pursue together with the PEL. In its manifestos for the 2013 Bundestagswabl and 2014 Europawabl, the party, for example, called for "a one-off tax payment on capital above one million Euros" "together with the European Left" (Die Linke, 2013a, p. 46-47; 2014a, p. 17; see also Party of the European Left, 2014, p. 5). In its manifesto for the 2019 Europawahl, it proposed "together with the European Left [...] a fund for social, inclusive, solidary and ecologic development” (2019, p. 27; see also Party of the European Left, 2019, p. 3).

Nevertheless, interviewees explained that they did not consider common positions of the PEL to be important as input to their own positions and campaigns during national and European elections (interviews 19, 21 and 30). One interviewee explained that the European dimension of the Left was not well developed and that the party focused mostly on national issues. They thus found that the party usually approached European policy from a national perspective. They also considered the programme of the Left to be similar to that of the PEL, but more concrete (interview 30).

Both at the EGP and the PEL, the value of the Europarty manifestos was mostly described in terms of its support to smaller parties. At the EGP, one interviewee mentioned that the smallest parties, with few capacities for election campaigning, internalised the agenda of the EGP to a much greater extent than larger parties (interview 20). This, for example, was the case for the Polish greens (interview 24). Similarly, in the case of the PEL, interviewees explained that the common manifestos or declarations were 
important for parties in smaller member states (interview 19) and also for parties in member states with a less stable Left, such as in Italy (interviews 21 and 30).

Finally, one interviewee at the SPD provided a historical example of how electoral positions of sister parties can be important when a party or party leader seeks to change its position within the national realm. This concerned programmatic influence from the United States and Great Britain during the 1990s. In Europe, British Labour prime minister Tony Blair at the time was the frontrunner of a 'new centre' or 'third way', economically liberal approach of social democrats. In the campaigns for the 1998 elections, SPD candidate Chancellor Gerhard Schröder similarly talked about 'die neue Mitte' (see also Blair \& Schröder, 1999). The approach led to major controversies, also within the SPD (e.g. Cuperus, 1999). Yet according to the interviewee, using the language of the movement in political communication during the 1998 campaign served to show that a vote for the SPD was not a 'risk'. To them, this strategy was important in the context of the preceding sixteen years of government under a CDU chancellor and the 'change' that the SPD advocated for the future (interview 27).

\section{Transnational party activities to acquire campaign expertise and enhance national campaign strategies}

In contrast to the limited importance attributed to electoral positions of sister parties and Europarties, transnational party activities with a view to exchange campaign expertise were prominent. All parties engaged in contacts with sister parties and Europarties about such issues as the structure, organisation, tools and content of campaigns. Interviewees from the SPD and the Greens particularly emphasized the importance of such activities. Exchanges by far and large took place at the operational, rather than at the political level. That is, between campaign managers and other campaign staff. They also mostly took place on an informal and bilateral basis with sister parties, although the Europarties were said to have increasingly taken up a role in facilitating the more systematic exchange of campaign expertise. For all parties, the goal of transnational party activities to acquire campaign expertise was the professionalisation of their election campaigns, most importantly for elections to the Bundestag.

Interviewees most frequently mentioned exchanges about campaign strategies with sister parties in Western Europe. The central party office of the SPD, the so-called WillyBrandt-Haus, regularly exchanged with the Swedish Social Democrats (Socialdemokraterna, SAP), the Dutch Labour Party (Partij van de Arbeid, PvdA), and the British Labour Party, but also with the French Socialist Party (Parti Socialiste, PS) (interviews 18, 27, 28, 29 and 31). At the Left, exchanges took place with the Danish Red-Green Alliance (EnhedslistenDe Rod-Gronne, Enhl.) and also with the radical left parties in Ireland and Austria, the Dutch Socialist Party (Socialistische Partij, SP), and the French Party of the Left (Parti de Gauche, PG) (interview 19). At the Greens as well, there were exchanges with the Dutch sister party GreenLeft (GroenLinks) and also in particular with the Finnish and the Austrian green parties (interviews 24 and 33). 
Although it was stressed that green parties in the EU were always a valuable example, the Greens also visited the campaigns of the US Democrats (interview 33), as did the SPD at various moments in time (interviews 27, 28, 31 and 33). One interviewee from the SPD, however, explained that this was most relevant when the Democrats had won elections. Visiting those who had lost elections was not very productive or motivating (interview 31). In September 2015, for example, leader of the SPD at the time Sigmar Gabriel brought in Jim Messina to help construct the campaign of the SPD for the 2017 Bundestagswahl. Messina had served as the campaign manager for the 2012 campaign of US democratic President Obama. He, however, left the campaign headquarters, the socalled Kampa, again before the "hot phase" of the election campaign took off (Jun, 2018, p. 16-17).

Mutual visits and exchanges on campaign strategies were often based on the personal contacts of individuals within the central party office who saw the value of transnational exchange and who occupied positions that allowed them to engage in transnational activities. At the Left most markedly, bilateral cooperation was said to be based on the personal contacts of staff to other radical left parties in Europe. Contacts took place via e-mail and over the telephone, but also through meetings in person, such as with the Danish Enhl. The information obtained from various contacts would then be discussed within the international committee of the Left, which supports the work of the central party board (interview 19). According to another interviewee, however, cooperation with other parties about electoral strategies for national elections was not very important (interview 30).

Within the SPD, exchanges included the regular organisation of workshops with sister parties. These workshops brought together a broader group of staff members (interviews 28 and 31). One interviewee explained that this was because campaign experts themselves knew best how to adapt acquired campaign expertise to the structures of the SPD (interview 28). For example, in the period running up to the 2013 Bundestagswabl, there were regular exchanges between the SPD and the Dutch PvdA. An interviewee explained that this 'network' was the result of a window of opportunity that emerged due to a re-organisation at the Willy-Brandt-Haus. Contacts started a year-and-a-half before the election and interaction became more intensive towards the election date. The participants in the three two-day meetings were campaign managers, about eight on each side. For the interviewee, having a small group helped to establish mutual trust and an openness to criticism (interview 18).

Other campaign seminars took place with the British Labour Party, as well as with the Swedish SAP (interviews 28 and 31). One interviewee provided the illustration of visits to Sweden, during which the heads of department from the Willy-Brandt-Haus exchanged with their counterparts of the SAP. There were also visits from the Swedish campaign manager to the SPD, as well as contacts on the level of communication managers, spokespersons, and advertising strategists (see e.g. Sozialdemokratische Partei Deutschlands, 2015). According to the interviewee, cooperation was more intensive one 
or two years before national elections. At this early stage, there would still be time for transnational exchanges and campaign plans were still in preparation (interview 28).

The Greens likewise exchanged campaign expertise during trainings and visits. This included many travels to green parties in other EU member states. Sometimes, these took place during the campaign of a sister party, such as during the last week of the Finnish Green League (Vihreä liitto, VIHR) campaign for the 2011 national elections. At other times, this took place in between elections, such as with the Dutch GreenLeft (interview 33). One interviewee mentioned that it was easy to establish such contacts, for instance through the Council meetings of the EGP, but also through bilateral phone calls (interview 33). The international secretary of the Greens also played a role in coordinating contacts (interview 25).

For all three parties, a common theme in transnational party activities on campaign expertise was that of the professionalisation of campaigning on the ground. This included so-called 'canvassing', also known as 'door-to-door' campaigning. Indeed, in response to Merkel's strategy to depoliticise issues during election campaigns, particularly the SPD and the Greens launched large door-to-door campaigns to mobilise voters during the 2013 Bundestagswabl. The instruments to do so were, however, not well established in Germany yet (Faas 2015, 241-242).

Hence, the most important result of contacts between the Dutch PvdA and the SPD in the running up to the 2013 Bundestagswabl was the development of a new campaign strategy for the SPD, which was based on the canvassing campaign used in the Netherlands.39 The strategy involved the mobilisation of a very large number of SPD volunteers to talk to voters directly (see Sozialdemokratische Partei Deutschlands, 2013b). The PvdA, in turn, was said to have benefitted from the comparatively advanced data system of the SPD (interview 18). Also exchanges between the SPD and the Swedish SAP concerned the topic of canvassing. In particular, the parties discussed the use of an app that allows for tracking voter responses and the use of geo-targeting in neighbourhoods based on socio-economic data (interview 28; see also Theiling, 2017).

Similarly, at the Greens, interviewees mostly brought up examples of campaign expertise about campaigning on the ground. There were exchanges with the French green party about canvassing (interview 33) and a grassroots campaigner of the Dutch GreenLeft provided a training at the German Greens (interview 24). The Greens also learned from the Finnish VIHR about a more active approach to campaigning on the ground. That is, the common practice in Germany was to wait until people approached campaigners on the street, which sometimes led to situations in which voters came to complain or to insult campaigners. From the VIHR, the Greens learned about how to actively approach voters (interview 33). Likewise, learning about the development of

39 The brochure that resulted from this (Sozialdemokratische Partei Deutschlands, 2013b) indeed also refers to "sister parties in the US, France and the Netherlands" that ran successful door-to-door campaigns based on mass mobilisation (p. 5). 
door-to-door campaigning was relevant to the Left and was, for example, discussed with the Danish Enhl. (interview 19).

The three German parties also exchanged other types of knowledge about campaign strategies with a view to enhance their own national campaigns. The Left engaged in various general discussions with sister parties about what did and what did not work well in campaigning. For example, the party was inspired by the campaign of JeanLuc Mélanchon of the French PG. Mélanchon's very concrete way of addressing voters helped the German Left to re-think its own, often theoretical way of explaining political issues. The party also borrowed or transformed some of the ideas of the Austrian left party The Change (Der $W$ anded), such as posters about tax dumping in the EU (interview 19).

The SPD tried to learn from the US Democrats about the use of social media, as well as about databases for data-based campaigning (interview 28). Developing a database with details about the population in each German constituency was also the task of Messina when he assisted the SPD's campaign for the 2017 Bundesstagswabl (Jun, 2018, p. 17; Klask and Krupa, 2017). Themes of workshops between the SPD and the Dutch PvdA with a view to the 2013 Bundestagswabl likewise concerned the use of social media and voter surveys, as well as the establishment of a permanent campaign (interview 18).

In addition, two interviewees discussed the historical importance of a tour of SPD staff to France, Great Britain, the Netherlands, Sweden, and the US in the running up to the 1998 Bundestagwabl. At the time, the question of how to professionalise the SPD's campaign was crucial in view of the SPD's attempt to return to the office of Chancellor after sixteen years in opposition (interviews 27 and 31). Most was learned from the large campaigns in the US and Great Britain. Expertise acquired included the professional use of polls, investing in the message to voters, and campaigning on the ground (interviews 27 and 29). The SPD also for the first time instituted the Kampa as an organisational body outside of the party headquarters, employing a large majority of staff from outside the headquarters to generate more innovative capacity (interview 27). This bore similarity to the organisation of the campaigns of the US democratic President Bill Clinton and British Labour prime minister Tony Blair (Holtz-Bacha, 2002, p. 29).

Although contacts with a view to acquire campaign expertise were thus prominent, there were also limits to cooperation. For example, at the SPD, internal party structures sometimes did not facilitate informal exchanges of campaign expertise with sister parties. One interviewee discussed that conflicts within the Willy-Brandt-Haus at higher political levels ahead of the 2013 Bundestagswahl were an impediment to the development of more fixed frameworks for contacts with sister parties about campaign strategies. Campaign managers did, however, use external cooperation as 'munition' to push for innovations within the organisation (interview 18). Another interviewee explained that it was oftentimes more efficient to find information online: travelling to other countries took valuable time and the staff of sister parties was not always open to discussions when the workload during campaigns was very high (interview 31). 
Moreover, strategies or techniques from sister parties had to be adapted to the context of the German society and political environment. At the Greens, one interviewee stressed that learning was not a matter of copy-pasting. Rather, they mostly used practices of sister parties as inspiration (interview 33). At the SPD, interviewees provided some examples of differences between national contexts. That is, the US model of data-based campaigning with micro-targeting was considered unsuitable given the German rules about privacy and data security (interview 28 and 31). Also the budget of the US Democrats was much higher not just in terms of its total amount, but also in terms of money spent to mobilise an individual voter (interview 31). Campaign strategists thus needed to think creatively about how to 'translate' ideas (interviews 24 and 31).

In this context, some interviewees found that being more 'similar' to another party was crucial to facilitate mutual exchange. With respect to cooperation between the SPD and the Dutch PvdA, for example, one interviewee remarked that the similarities between the two parties were highly important - although differences between the two party cultures and organisations were still striking. To them, the importance of being similar also explained why the focus of the 'network' about campaigning between social democratic parties was on North-Western Europe (interview 18). Another interviewee found that much could be learned from parties acting in political systems similar to that of Germany, such as in Sweden, Norway, Finland, and the Netherlands. This was different for parties in post-communist states (interview 28). The ability to speak the same language was also mentioned as a relevant aspect (interview 24). One interviewee, however, emphasized that the issue was not just one of sharing a similar political and party culture. To them, relevant expertise could be acquired from sister parties that were electorally successful and organisationally well-functioning (interview 31).

Finally, several interviewees discussed that Europarties had started to take up a more prominent role in facilitating more institutionalised exchange on electoral strategies. To start with, the PES provided an avenue to reach out to sister parties already in the late 1990s (interview 31). Yet towards the 2014 and 2019 European elections, it reinforced frameworks to facilitate the exchange of best practices between campaign leaders (Party of European Socialists, 2015b, p. 3). This included a European and a national campaign managers network, at which campaign managers exchanged ideas and best practices (interview 23).

Meetings and workshops on campaigning organised by the PES were also considered relevant by the SPD (interview 29). One interviewee explained that exchanges about campaigning with sister parties through the PES had indeed become more prevalent in the most recent European election campaigns (interview 34). Moreover, the regular meetings organised at the PES in general meant that sister parties were more likely to meet at the PES than through bilateral platforms (interview 26). Nevertheless, one interviewee explained that the PES became a focal point particularly for smaller parties. For the SPD, both multilateral and bilateral interactions remained important, given its the relatively strong position within the party family (interview 28). 
For the Greens, the EGP functioned as an important "contact hub" (interview 20), as it supported and provided access to networks (interviews 24 and 25). One interviewee explained that parties usually searched for contacts with sister parties through the EGP, as this was easier than seeking contacts directly (interview 20). Via the international secretaries of national parties, questions about relevant contacts in sister parties were mostly directed to the staff member at the EGP in charge of relations with national parties (interviews 20 and 25). Contacts could then be further pursued outside of the EGP (interview 24). The international secretaries hence played an important role in the network of the EGP, although the organisational standing of these secretaries differed across national green parties (interviews 20 and 25). At the Greens, for example, the position was only created within the central party board in January 2018 (interview 25).

Finally, also the PEL facilitated bilateral cooperation between parties by providing a network of parties, but this was limited in comparison to the PES and the EGP. One interviewee at the Left explained that the network of the PEL facilitated further informal contacts with individual parties, but that not all radical left parties were part of the PEL. Hence, the Left also spent considerable time and energy on establishing bilateral contacts with parties outside of the PEL, such as with the radical left government party in Iceland (interview 19). The PEL also had a working group on campaigns and communications, inter alia charged with social media. It was, however, small and still in its infancy, not least because the members of this "communication working group" worked on a voluntary basis. This meant that its work was not very effective (interview 19).

\section{Drawing on 'successful' sister parties and visible Spitzenkandidaten to foster public legitimacy}

To seek the benefits of office, national parties may engage in transnational party activities to seek public legitimacy and foster a perception with the national public as a capable government or legitimate opposition party. During the Bundestagswablen and Europawablen between 2013 and 2019, the three German parties engaged in some transnational party activities with sister parties to do so. Interviewees at the SPD and the Greens discussed some examples of joined activities with successful sister parties to seek public legitimacy in view of national elections to the Bundestag and also the Left relied on some of its sister parties. For the 2014 and 2019 European elections, the SPD and the Greens by far and large drew on their own Spitzenkandidaten to foster an image of being a competent, 'European' party. Only the Left and the Greens explicitly affiliated themselves with their Europarty in European election manifestos.

All three parties occasionally invited leaders from successful sister parties to speech at their party congresses. For example, the Dutch party leader of the GreenLeft, Jesse Klaver, was invited to speak at the 2017 general party congress of the German Greens - three months prior to the 2017 Bundestagswabl. One interviewee explained that this was primarily because GreenLeft was very successful in the Netherlands at the time, while the German Greens faced declining support in opinion polls (interview 24). The Greens had also incurred major losses in the May 2017 state elections in North-Rhine 
Westphalia (Lees, 2018, p. 124). Amongst other issues, in his speech, Klaver talked about the successful campaign of the GreenLeft (Bündnis 90/Die Grünen, 2017). It was hoped that this success would "radiate" on the German Greens (interview 24, see also Braun, 2017). The Left likewise hosted speeches from foreign leaders at their congresses, such as by leader of the Portuguese Left Bloc Francisco Louçã in 2012 and by deputy leader and MEP of the same party Marisa Matias in 2013 (Die Linke, 2012; 2013b).

The SPD organised various events with leaders of sister parties. For example, party leader of the Spanish Socialist Workers' Party (Partido Socialista Obrero Español, PSOE) at the time, Pedro Sánchez, spoke at the 2018 SPD party congress, at which the SPD elected its new party leader (Sozialdemokratische Partei Deutschlands, 2018, p. 22-25). And at the 2013 congress, Italian prime minister of the Democratic Party (Partito Democratico, PD), Enrico Letta, took the floor (Sozialdemokratische Partei Deutschlands, 2013, p. 114-119).

During the 2013 Bundestagswahl, candidate Chancellor Peer Streinbrück travelled through Europe. He, for example, visited the social democratic French President at the time, François Hollande (interview 34; see also Wiegel, 2013). In the late 1990s, the SPD had also organised several international conferences on the economy where it invited sister parties, including, for example, representatives from social democratic parties in Great Britain, Italy, and the US, as well as the social democratic leaders at the time from Austria and Sweden (interview 27).

Interviewees explained that these events were intended to demonstrate the competence and political relevance of the SPD. One interviewee, for example, said that the purpose of the international conferences towards the 1998 Bundestagswabl was to show voters that the SPD knew how to act internationally. This was important, as the SPD wanted to return to government office after much time in opposition. That is, in opposition, the international arena is 'blocked' by government parties. An international conference, then, provides an image of nevertheless having a strong community, network, and know-how on international affairs (interview 27). Another interviewee likewise explained that the purpose of rallies with and visits to sister parties during later national elections was to show the capability of the SPD to act at the European level. That is, as government party, the SPD would be able to draw on networks and common positions with other social democrats in government office. Also in their view, showing that a candidate Chancellor sees 'eye-to-eye' with incumbent social democratic leaders in the EU was particularly relevant when the SPD had been in opposition during the legislative term before the elections, as was the case for the 2013 Bundestagswahl (interview 34).

During the 2014 and 2019 European elections, the three parties also drew on the lead candidates for Commission President elected by their Europarties. This helped to foster an image of being a party capable of acting at the European level. The Left, however, only did so for the Europawahl of 2014. The party invited the Spitzenkandidat of the PEL - Alexis Tsipras from the Greek Coalition of the Radical Left (Synaspismós Rizospastikis Aristerás, Syriza) - to speech at its party congress two weeks prior to election day (Die Linke, 2014b). The party also referred to Tsipras as the candidate of the German 
Left for Commission President in its electoral strategy for the 2014 Europawabl (Die Linke, 2014c).

The SPD and the Greens mostly relied on their own Spitzenkandidaten, who were also lead candidates for their European party. At the Greens, for example, one interviewee explained that the party found it highly important to support the Spitzenkandidaten system and to work towards the development of transnational lists, given its "DNA" as a European party. This was the case even though the party had the capacity to run its own campaign (interview 33). For another interviewee, the European identity of the Greens implied that the party would have campaigned for the Spitzenkandidaten even if these candidates had been from another EU member state. They found this necessary in view of the democratic legitimacy of the election of the President of the Commission (interview 25).

During the campaigns for the 2019 Europawablen, the Greens mostly adopted the story that their national lead candidate, Ska Keller, was present also in the rest of Europe as a candidate for European Commission President. She had a strong European profile and could explain the EU based on her own expertise. This was also as the result of her co-presidency of the Greens/EFA in the European Parliament (interview 25). Events with the other Spitzenkandidat, Bas Eickhout from the Dutch GreenLeft, were, however, much more limited (interview 25).

Similarly, in the 2014 Europawabl, the strategy of the SPD was to construct its campaign around the pro-European character of Martin Schulz. Schulz was the PES Spitzenkandidat as well as the national lead candidate of the SPD at the time (interview 27; see also Sozialdemokratische Partei Deutschlands, 2014b, p. 9). Through telling the story about Schulz's candidacy for President of the Commission, the SPD closely linked the campaigns that ran at the national and European level (interview 34). One interviewee explained that one reason for the emphasis on Schulz was that programmatic differences between the SPD and the other national parties only concerned highly technical issues or issues on which the electorate was clearly positioned against or in favour. Hence, these differences were considered unsuitable as the basis for the campaign. It was perceived that the one difference that did exist was that of the personality of the Spitzenkandidat (interview 27). In other words, the SPD effectively turned the campaign into a competition for office, rather than a competition over policies.

The personality of Frans Timmermans did not, however, play a similar role during the campaign of the 2019 Europawabl (interview 27), as - although he spoke German Timmermans came from the Dutch PvdA. One interviewee, however, mentioned that the SPD did find it relevant to give visibility to Timmermans, for example through television debates. They explained that this was because data had shown that the public knew Timmermans and his main opponent - the German Manfred Weber of the CSU - about just as well. Moreover, the principle of having Spitzenkandidaten had become known to the German public (interview 34). In this context, another interviewee signalled that the significance of European party families, as well as the awareness and understanding of 
these families, had increased in Germany. This was not least so in the context of debates about the EPP membership of Viktor Orbán's Fidesz in the running up to the 2019 elections (interview 28). Finally, there was also an internal party dynamic to the Spitzenkandidaten system. That is, Frans Timmermans visited the SPD's conference on the EU elections in November 2018 so as to raise awareness of the European elections within the SPD. The visit also served to show support to Timmermans (interview 29).

Finally, in their party manifestos for elections in Germany between 2013 and 2019, the Greens and the Left included some explicit references to their Europarty affiliations. The Greens did so in their manifestos for the 2014 and 2019 European elections. The preambles of both manifestos mentioned that the Greens are a member of the EGP and that strive to realise their ideas in cooperation with the green party family (Bündnis 90/Die Grünen, 2014; 2018). The Left likewise affiliated itself with their Europarty and with radical left sister parties more broadly (e.g. Die Linke, 2017, p. 103; 2019, p. 44, 48, 59). In its manifesto for the 2014 Europawabl, the party also explicitly mentioned its support for Tsipras (2014a, p. 6). Yet in 2019, it did not do so again for the Spitzenkandidaten Violeta Tomić and Nico Cué.

By contrast, the party manifestos of the SPD did not mention membership of the PES. The 2014 manifesto did, however, refer to the "party family" of "European social democracy" in the context of the nomination of Martin Schulz as "Spitzenkandidat of all European social democrats" (Sozialdemokratische Partei Deutschlands, 2014a, p. 3). In 2019, however, the manifesto neither referred to Frans Timmermans, nor to the very presence of a European social democratic Spitzenkandidat (Sozialdemokratische Partei Deutschlands, 2019).

\section{The perceived importance of establishing collective electoral positions}

The sub-section on transnational party activities to acquire electoral positions already shows that the SPD, the Left and the Greens relied on their own party resources to formulate manifestos for national and European elections. With regard to the resource dependency of collective electoral positions, then, the Europarty common manifestos were at best a limited input into the national manifesto for European elections. Nonetheless, interviewees at all parties found it very important to invest in collective electoral positions. Hence, the SPD, the Left, and the Greens all played a key role in the formulation of common party manifestos of their Europarties.

The Greens were very closely involved in the formulation of the manifesto of the EGP. Over the course of 2018, for example, the Greens participated in the various meetings and conference calls of the manifesto working group of the EGP to prepare the Europarty manifesto for the 2019 elections. Moreover, the Greens were also in bilateral contact with the Dutch GreenLeft about the development of the election programme. One interviewee explained that, in the process of formulating the manifesto, disagreements mostly concerned different priorities of member parties. For example, while transparency was a big issue in the German context, tax evasions were salient in 
Greece. The role of the EGP was to moderate such disagreements between national green parties (interview 20; see also European Green Party, 2018c). In the perception of the interviewee, the Greens managed to 'upload' many of their preferences in the process of negotiating priorities (interview 25; see also European Green Party, 2018d).

For one interviewee, the common EGP manifesto for the European elections that emerged from the negotiations reflected the consensus that green parties could reach, given the heterogeneous preferences within the party family. To them, this consensus was most importantly about the issue of climate change (interview 33). To another interviewee, however, the consensus represented a set of issues from which national party could "pick" priorities and focal points (interview 25). In addition, it was suggested that the Spitzenkandidaten played an important role in setting the political agenda for national debates during the European elections. Ska Keller was associated with the topics of migration and tax evasion, while Bas Eickhout was known for his work on climate change in the EP. These topics supported a narrative of a "green way" that member parties could jump on (interview 20).

Why were common positions important to the Greens, despite their perceived low value for the Europawabl nationally? One interviewee reasoned that larger players within the EGP generally needed the common manifesto the least, but used the EGP the most. They explained that this was because common party manifestos create a 'liability' for larger parties - such as the German Greens - in the national election campaign. Common positions may constitute a risk in national debates if the press or other national parties hold them against you. Larger parties thus sought to manage their liabilities, for instance through in-depth discussions about the content of the manifesto (interview 12). Another interviewee argued that the Greens had to invest in a collective campaign and collective positions through the EGP, because it perceived itself as a party with a strong European identity (interview 33). Having collective positions was thus important for both normative and political reasons.

Also at the SPD, it was considered highly important to have a common party manifesto of the PES, as well as a common campaign based on that manifesto. This was mainly explained in terms of the political stance of the SPD in favour of further European integration (interviews 27 and 28). One interviewee, for example, found that too little was still done in terms of developing a common programme and a common line of communication (interview 27). Another interviewee explained that having a common manifesto was core to the further development of a future European political sphere. In this sphere, Europarties would also play an important role (see also Sozialdemokratische Partei Deutschlands, 2019, p. 70). In view of the European elections, the SPD thus pushed forward on a PES manifesto, even when some social democratic parties - such as the Scandinavians - wanted to hold it back (interview 28).

The international secretariat of the SPD, in coordination with the party leadership, was the key SPD actor in the negotiations about the common PES manifestos for European elections. The PES worked on the common manifestos primarily through 
discussions between the international secretaries of the PES member parties in a 'coordination team'. This process took several rounds of revisions. It was based on a first draft by the PES and subsequent amendments from the national parties. Within the SPD, there was no standard procedure to involve the internal party organisation. One interviewee, however, explained that the international secretariat did at some stage try to involve the SPD delegates to the PES Congress who would vote on the manifesto. Whether these delegates were actually involved also depended on the availability of time, so that this consultation process was not organised during every preparation for European elections (interview 34).

The Left also engaged in various contacts with the PEL before the 2014 and 2019 European elections to discuss the formulation of a common programme. These contacts included discussions about the central messages of the PEL for the elections, as well as the elaboration of these messages (interview 19). One interviewee explained that the discussions showed what themes were of national importance and what themes were of collective importance (interview 19). In the process of formulating a common manifesto, the German President of the PEL and key politician of the Left, Gregor Gysi, played an important role (interview 30). The Left was said to have had no clear priorities about what should be in a common manifesto of the PEL (interview 30). Yet a common declaration of the Left was considered important as a "symbolic" expression of the European Left (interview 30) and also as a step towards the development of a self-understanding of the European left (interview 21).

Nevertheless, the formulation of collective electoral positions was complicated by disagreements within the ranks of the radical left party family, not least about the future of European integration. One interviewee also explained that there was a culture within the PEL of not discussing issues on which the member parties could not find a compromise. Any common documents thus reflected a 'lowest common dominator' position. The German Left tried to stabilise and moderate disagreements. To the interviewee, this was not only because the Left is numerically one of the largest radical left parties in the European Parliament and is from one of the most influential EU member states, but also because the party has a historical duty to 'think' European (interview 21).

\section{Attempts and difficulties to establish collective campaign strategies}

Concerning the final resource dependency about vote seeking on the European level, collective campaign strategies, it is clear that both the SPD, the Greens, and the Left upheld the idea of having lead candidates for European Commission President. Their respective Europarties also all elected Spitzenkandidaten for the 2014 and 2019 European elections. The actual transnational party activities of the German parties with a view to develop a common election campaign and a common lead candidate were, however, most prominent at the Greens and least prominent at the Left. At the SPD, several interviewees stressed the desirability of having more engagement in a collective PES campaign. Finally, 
particularly interviewees from the SPD and the Left brought up challenges for the establishment of collective campaigns.

For the 2019 European elections, the SPD insisted on the election of a PES Spitzenkandidat, although this was not uncontested within the party family at the time (interview 28). This position can be understood not only by the relatively strong support of the SPD for European integration (see e.g. Sozialdemokratische Partei Deutschlands, 2019, p. 70-71), but also by the close relation of the SPD to the principle of the Spitzenkandidaten. Specifically, the PES candidate for the 2014 European elections, Martin Schulz, came from within the ranks of the SPD. Schulz had also been closely involved in making the innovation of the Spitzenkandidaten process happen. The PES Secretary General, Achim Post, was likewise a politician from the SPD, and had been closely involved in developing the selection procedure for the Spitzenkandidat within the PES (interview 34). Moreover, one interviewee explained that it was important to the SPD to have a common campaign and that the election of a Spitzenkandidat implied the development of a such a campaign (interview 28).

The Greens supported their own candidate Ska Keller as one of the two lead candidates of the EGP, both for the 2014 and 2019 European elections. For the 2014 European elections, the EGP had organised an online primary in which European citizens could elect the two Spitzenkandidaten. Yet in the running up to the 2019 elections, not enough green parties were involved to organise such a public consultation again. Because it was found important to have all parties on board, the EGP Council thus elected the Spitzenkandidaten after an internal process. In this process, the Greens also supported the Dutch candidate Bas Eickhout, while the Dutch GreenLeft supported Ska Keller in return. The two parties subsequently liaised with each other to discuss the division of topics between the two candidates, so as to allow for having different focuses during the campaign (interview 25). One interviewee, however, mentioned that a drawback of having Keller run both as the German national Spitzenkandidat and as EGP Spitzenkandidat in the 2019 Europwahl was that there was less time for campaigning in Germany, given Keller's appointments throughout the EU (interview 25).

By contrast, both for the 2014 and 2019 European elections, the Left did not support a lead candidate of the PEL from within its own ranks. One interviewee explained that it was the position of the Left that a Spitzenkandidat should not be German, given the weight that the Left already had within the PEL and given the historical legacy of Germany in Europe (interview 21). Nevertheless, Gregor Gysi played an important role in finding Spitzenkandidaten for the 2019 elections. According to one interviewee, it was the Left that pushed for the election of Violeta Tomic of the Slovenian The Left (Levica) (interview 30).

The SPD and the Greens were also involved in other collective campaign strategies, while this was much more limited for the Left. One interviewee mentioned that the Left, within the PEL, attempted to develop a common campaign, but that this remained very limited (interview 30). Another interviewee explained that the election 
materials that the PEL developed based on the common manifesto were not important for the campaign in Germany (see also Die Linke, 2014c; 2018). They found that these materials were more relevant to radical left parties in smaller countries. Moreover, they mentioned that the German public was rather uninterested in the EU compared to voters elsewhere, such as in Austria (interview 19). Nonetheless, the Left shared posters of the European election campaign of the French communist party on its website for the 2014 elections (Die Linke, n.d.). An interviewee explained that they also shared posters through social media channels, such as those of the Austrian The Change (interview 19).

The PES launched various new initiatives to develop collective campaign strategies in the running up to the 2014 and 2019 European elections. In 2014, for example, the Europarty launched a European training academy to invest in transnational networks between young Socialists and in acquainting more people within national parties with European affairs (interview 23; see also Party of European Socialists, 2014b). In September 2018, the PES also launched a Campaign Academy. This included the organisation of large, two-day meetings called "campaign camps" alongside the PES conferences (interview 23). To these academies, the PES invited speakers from within and outside of Europe involved in the organisation of campaigns, including campaign managers from the US Democrats (interview 23; see also Party of European Socialists, 2018a). Ultimately, it was the ambition of the PES to train 15.000 activists from member parties (Party of European Socialists, 2018b).

According to one interviewee, the SPD adopted a leading role in such PES networks, not only because of its historically unique position in European integration, but also because it was concerned about the rise of Eurosceptic actors (interview 23). Several interviewees at the SPD indeed stressed that they found it highly important to have common campaign strategies. They, for example, stressed the urgency of preparing a common campaign structure at least two years ahead of European elections (interview 31). They also highlighted the significance of training of activists as a 'learning scheme' within the PES and an investment in campaign capital (interview 27). Nevertheless, it was widely perceived that the common PES campaign was still limited and that more should be done in the future (interviews 27, 29, 31 and 34). This would, for example, include individual PES membership rights (interview 31) and the development of a real transnational social media campaign (interview 31).

The EGP also invested in the development of a common campaign. The work for the campaign of the 2019 European elections started three years ahead. This process was described as 'bottom-up'. For example, party leaders and staff members of national parties drafted the plan for the preparation of the EGP campaign at the Council meeting in Sweden, in 2017 (interview 20). In January 2019, a communication working group started its work, functioning as a 'fast response' team (interview 20). Collective electoral resources and strategies most importantly included online campaign material, the joint organisation of electoral events about Europe, own events of the EGP, and, in the 2019 elections, the digital citizens' movement Tilt!. The latter also included a go-to-vote 
campaign (interview 20; see also European Green Party, 2018c, p. 3, 7-11). During the campaign, resources were distributed according to the demand of national parties. Particularly small and medium-sized Green parties made use of this (interview 20 and 33, see also see also European Green Party, 2018c, p. 5). There was, however, also a priority to countries that were on the verge of having one more MEPs in the polls (interview 20).

Despite being a relatively large party within the green party family, the Greens considered the collective content of the EGP valuable. The party saw a common campaign as the logical next step after the development of collective positions. Hence, campaign content from the EGP, such as tweets and videos, was also shared in the national campaign for the Europawablen (interview 25). More generally, one interviewee characterised the relation between the German Greens and the EGP as reciprocal. The Greens shared their experience with running large campaigns, while the EGP had the capacity to translate this experience to the European context (interview 25). Another interviewee found the sharing of electoral strategies with sister parties highly important, not only for European, but also for national elections. They argued that, beyond being a strong party nationally, the Greens could only reach their political goals by acting on a European basis and by contributing to a strong European green family (interview 33).

To facilitate exchange on the more strategic aspects of the common campaign, the department of public relations was closely connected to that of the EGP for the duration of the European campaigns (interview 25). Activities included meetings with other national campaign staff through the EGP's campaign working groups. During the 2019 campaign, exchange of content took place through the online collaboration hub 'Slack' (European Green Party, 2018c, p. 13). For the 2019 Europawabl, the Greens also organised a separate meeting to discuss storytelling and campaign strategies, which was also attended by the EGP. This provided a starting point for the further development of the national campaign of the Greens (interview 25). Moreover, one interviewee mentioned that Reinhard Bütikofer, co-chair of the EGP and MEP for the Greens, and Ska Keller, Spitzenkandidat and member of Board of the Greens, provided the Greens with a strong position in exchanges about strategic issues with the EGP (interview 25).

Interviewees at all three parties, however, also brought up challenges to the organisation of their collective campaigns. First, at the level of the Europarties, interviewees commented on the financial regulations for Europarties (interviews 20 and 23). One interviewee, for example, explained that it was problematic that the European regulation was not in line with national rules about campaign funding (interview 20). For example, in some countries, like in France, no external funding of local or national campaigns is allowed, while for the European rules, an event or campaign only counts as 'European' when it involves seven to eight member states (interview 20).

Second, at the level of the national parties, interviewees brought up challenges in the coordination of collective strategies. This was the case at the SPD most markedly. To start with, the practical coordination of campaign strategies was difficult when the SPD only appointed its campaign managers half a year prior to the Europawablen. This, for 
example, was the case for the 2014 Europawabl (interview 27) and had also been the case for the 2009 Europawabl (interview 31). Attempts to exchange strategies came too late (interview 27), and that there was too little time to really interact with the PES and with sister parties (interview 31). Moreover, one interviewee explained that there were suggestions, also from within the SPD, to develop a real structure for the coordination of a PES campaign, but that this was not put in place. They suggested that this was a result of a pre-occupation with the different political situations within member states (interview 31).

At the Left, coordination of campaigns with the PEL was highly limited. This was not only because the extent of a common campaign remained very small, but also because the staff of the PEL only comprised of a handful of full-time employees. Any efforts to coordinate campaigns across Europe were thus limited (interview 19). At the Greens, interviewees did not bring up specific challenges related to coordination with the EGP or with sister parties. One interviewee, however, stressed that the election campaigns also required coordination with the fractions of the Greens on the local level. The latter had different priorities depending on their area (interview 25). At the EGP, an interviewee mentioned that having local or national campaigns simultaneously with European elections was a challenge to the organisation of a common green campaign, because such campaigns left no room for European issues. Also in some German states, local or federal elections took place simultaneously with European elections (interview 20).

Finally, at all three political parties, interviewees mentioned that the extent of a common campaign was limited by different preferences within the party family. At the SPD, for example, one interviewee mentioned that there was no real ability yet to have a common campaign, because there was no common political sphere (interview 29). Hence, in practice, national parties did not implement a common campaign (interviews 29 and 34). Another interviewee mentioned that the SPD would have wanted to work towards transnational lists, but that other parties rejected this, including the Danish and British social democrats (interview 28). While there was more common ground within the green family, one interviewee likewise mentioned that the common campaign was limited by the consensus that could be reached and that the campaign of the Greens for the Europawablen was still run on a national basis mostly (interview 33).

Interviewees of the Left brought up more fundamental divisions within the party family, as well as within the own party. Some important and larger radical left parties were not a member of the PEL, including the Spanish We can (Podemos). Moreover, in 2018, the movement DiEM25 of Yannis Varoufakis, former Syriza finance minister in Greece, launched a transnational electoral list for the 2019 European elections. Varoufakis himself ran during the Europawabl in Germany, separately to the German Left. Clearly, these developments were not to the benefit of the Left, as it led to direct competition over leftwing voters (interviews 21 and 30).

In the year preceding the 2019 European elections, the Party of the European Left also became divided. Most importantly, the French PG, member of Jean-Luc 
Mélenchon's movement La France Insoumise ('Unsubmissive France') and co-founded by Mélenchon himself, withdrew from the PEL over disagreements about Syriza's membership of the PEL. In a message to the Council of Chairpersons of the PEL, the PG argued that Syriza had adopted an "austeritarian logic" and "imposed a drama on the Greek people", and should hence be excluded from the PEL (Parti de Gauche, 2018). Gregor Gysi, in return, made clear that the PEL "would not fare better but clearly worse during European elections in 2019" without Syriza (Party of the European Left, 2018). One interviewee also explained that solidarity with Syriza was important to the German Left, given the history of Germany and the role of the country in the managing of the government-debt crisis in Greece (interview 21). Subsequently, in April 2018, La France Insoumise, the Portuguese Left Bloc, one of the founding parties of the PEL, and the Spanish Podemos launched a separate platform to campaign in the 2019 European elections, called Now the People (Maintenant le Peuple). Also the Danish, Finnish, and Swedish radical left parties supported it.

There were thus, in effect, three radical left strategies during the 2019 European elections, namely that of the PEL, which wanted to be a platform for the entire family, of Now the People, and of Varoufakis' Diem25 (interview 30). This also led to disagreements within the German Left. Katja Kipping, one of the co-chairs of the Left, had openly supported the launch of DiEM25 (interview 21; see also Hecht, 2018). Sahra Wagenknecht, chair of the Left in the Bundestag, launched a new left-wing political movement called Aufstehen ('Stand up') in September 2018. She sympathised with La France Insoumise of Mélenchon, and her movement was both similar and connected to it (interview 21; see also Jesse, 2018).

At the German Left, some interviewees were dissatisfied with the resulting fragmentation of the party family. For example, one interviewee explained that the Left had an important responsibility towards the PEL given its role within the Europarty (interview 21). In the eyes of another interviewee, sufficient common ground for a collective strategy did exist, based on positions on issues such as austerity, militarisation, and social rights (interview 30). Both interviewees also saw a common strategy as urgent, given the rise of far-right parties across Europe (interviews 21 and 30). One interviewee found the European Forum, a platform launched in 2017 that brings together both socialist, green, and radical left parties, an important vehicle to arrive at a more united party family in the future. They, however, also noted that this perception was not shared within the entire German Left (interview 30).

\section{5 | Comparative analysis}

This final section of the chapter analyses the findings about the transnational party activities of the SPD, the Left, and the Greens with a view to the 2013 and 2017 Bundestagswablen, and the 2014 and 2017 Europawablen. In relation to the first research question of this dissertation about what drives the transnational party activities of national 
parties in the EU, I analyse the motivations for the central party offices to engage in transnational party activities within the case of the national and European elections. In relation to the second research question about the conditions under which national parties engage in transnational party activities, I compare the findings across the cases of the SPD, the Left, and the Greens.

\section{Motivations to engage in transnational party activities to seek electoral success and the benefits of office}

On the one hand, transnational party activities to seek electoral success and the benefits of office at the national level are driven by actual resource needs. Most importantly, the transnational activities of the SPD, the Left and the Greens were driven by a need for campaign expertise. The exchange of campaign expertise with sister parties regularly went beyond an occasional exchange of best practices, even when transnational activities were based on personal contacts of individuals within the central party office. The purpose of acquiring this expertise was to professionalise party campaigns for the Bundestagswablen. Campaign expertise was often about the use of information and communication technologies in campaigning, including the use of large databases and social media. Some transnational party activities were also driven by a need to acquire public legitimacy as a relevant and competent political party. These activities involved visits by or to sister parties and events with Spitzenkandidaten. For the period 2013-2019, there is very little evidence of transnational party activities motivated by a need to acquire electoral positions for the national realm.

On the other hand, transnational party activities to seek electoral success at the European level are driven by a concern with managing normative expectations about the aspects of a 'real' or 'good' European campaign. That is, the SPD, the Left, and the Greens did not themselves need collective electoral positions and collective campaign strategies as actual resources for their own national campaign. Nevertheless, the three parties still perceived a strong sense of responsibility for the development of a Europarty manifesto and campaign. In line with Resource Dependence Theory, this behaviour can best be understood as the management of social demands about the outcomes that the parties should strive for. Interestingly, the perceived demands about legitimate behaviour during European election campaigns were stemming both from the domestic and European arena. Interviewees at the SPD and the Greens perceived that active involvement in the formulation of Europarty manifestos and campaigns was necessary in light of their ideological support for further European integration. Interviewees at the Left found that the Left had to actively engage with the formulation of common positions and campaigns given Germany's historical legacy in Europe and recent dominance in EU decision making.

Moreover, there is anecdotal evidence that parties had to manage conflicting demands about legitimate courses of action. The SPD occasionally had to manage conflicts between normative expectations at home and the preferences of sister parties in 
the EU. For instance, some sister parties were opposed to the Spitzenkandidaten process, but to the SPD it was important to uphold the Spitzenkandidaten process in view of its ideological position about the future of European integration. The Left supported the idea of the Spitzenkandidaten, but also believed that the candidate should not be a German politician given the already dominant position of the German Left within the PEL. At times, parties thus faced a 'trade-off' between managing trans-organisational legitimacy - that is, maintaining a coalition of support among sister parties - and managing social demands about how parties that support a particular idea about European integration should act.

\section{System-level factors that condition motivations to engage in transnational party activities to seek electoral success and the benefits of office}

Table 20 summarises the findings of the case study on transnational party activities in the context of campaigning for national and European elections. The table reports on the overall level of importance that interviewees from the SPD, the Left, and the Greens ascribed to transnational party activities to manage particular resource dependencies (see chapter 4, section 4.4). The discussion shows, however, that there were anecdotal inconsistencies between the perceptions of different interviewees within the same political party. For example, at the Left, one interviewee found campaign expertise from sister parties mostly irrelevant (interview 30), but another interviewee engaged in exchanges with sister parties about campaign strategies that they perceived as relevant (interview 19).

The comparison between the activities of the SPD, the Left and the Greens provides mixed evidence concerning the three (sets of) theoretical expectations about the conditions under which national parties engage in transnational party activities.

First, several findings confirm expectation (1.1) that parties that face a changing electorate have more incentives to engage in transnational party activities with a view to vote-seeking. This dynamic can primarily be observed with regard to transnational activities to acquire campaign expertise for electoral success at the national level. A most striking example is that of the SPD, which brought in the campaign manager of Barack Obama for the 2017 Bundestagswabl, during a time when it faced declining electoral support.40 The party also sought cooperation with several of its European sister parties, most importantly to acquire expertise about mobilising voters. Also the Greens sought to learn from the campaign strategies of sister parties to mobilise voters when they faced slides in the polls. There is, however, no evidence that parties that face a changing electorate also find collective electoral positions and strategies more important.

40 An alternative explanation from the literature on the professionalisation of party campaigns is that new party leaders seek to push professional campaigning to reinforce their leadership (Gibson \& Römmele, 2001) 
Table 20 | Resource dependencies and the transnational party activities of the SPD, the Left and the Greens with a view to Bundestagswahlen and Europawahlen

\begin{tabular}{|c|c|c|}
\hline $\begin{array}{l}\text { Political party } \\
\text { (in central } \\
\text { party office) }\end{array}$ & $\begin{array}{l}\text { Resource dependencies related to } \\
\text { party goals at the national level }\end{array}$ & $\begin{array}{l}\text { Resource dependencies related to } \\
\text { party goals at the European level }\end{array}$ \\
\hline SPD & $\begin{array}{l}\text { - Limited importance attributed to } \\
\text { acquiring electoral positions through } \\
\text { transnational party activities; } \\
\text { - Substantial importance attributed to } \\
\text { acquiring campaign expertise through } \\
\text { transnational party activities; } \\
\text { - Some importance attributed to } \\
\text { obtaining public legitimacy through } \\
\text { visits of sister parties and } \\
\text { Spitzenkandidaten. }\end{array}$ & $\begin{array}{l}\text { - Substantial importance attributed to } \\
\text { developing collective political positions } \\
\text { through the Europarty, but some } \\
\text { activities in practice; } \\
\text { - Substantial importance attributed to } \\
\text { establishing collective campaign strategies, } \\
\text { but some activities in practice. }\end{array}$ \\
\hline The Left & $\begin{array}{l}\text { - No importance attributed to } \\
\text { acquiring electoral positions; } \\
\text { - Some importance attributed } \\
\text { acquiring campaign expertise through } \\
\text { transnational party activities; } \\
\text { - Some importance attributed to } \\
\text { obtaining public legitimacy through } \\
\text { visits of sister parties and } \\
\text { Spitzenkandidaten. }\end{array}$ & $\begin{array}{l}\text { - Substantial importance attributed to } \\
\text { developing collective political positions } \\
\text { through the Europarty, but limited } \\
\text { activities in practice; } \\
\text { - Some importance attributed to } \\
\text { establishing collective campaign strategies, } \\
\text { but limited activities in practice. }\end{array}$ \\
\hline The Greens & $\begin{array}{l}\text { - Limited importance attributed to } \\
\text { acquiring electoral positions through } \\
\text { transnational party activities; } \\
\text { - Substantial importance attributed to } \\
\text { acquiring campaign expertise through } \\
\text { transnational party activities; } \\
\text { - Some importance attributed to } \\
\text { obtaining public legitimacy through } \\
\text { visits of sister parties and } \\
\text { Spitzenkandidaten. }\end{array}$ & $\begin{array}{l}\text { - Substantial importance attributed to } \\
\text { developing collective political positions } \\
\text { through the Europarty, and } \\
\text { substantial activities in practice; } \\
\text { - Substantial importance attributed to } \\
\text { establishing collective campaign strategies, } \\
\text { and substantial activities in practice. }\end{array}$ \\
\hline
\end{tabular}

In more general terms, the concern of the three left-wing parties with acquiring knowledge from sister parties about the use of modern technologies for communication and information-gathering can be understood by a need to respond to societal changes. This is in line with the fundamental premise of the literature on the professionalisation of party campaigns. That is, political parties seek to alter their campaign strategies to respond to changes in the political system and the media that result from the "modernisation of society" (Negrine, 2007, p. 28; see also Gibson \& Römmele, 2001).

The interview findings, however, also suggest that similar campaign practices and understanding of professional campaigning of parties across Europe (e.g. Tenscher, Mykkänen \& Moring, 2012; Tenscher et al., 2016) do not just result from similar societal 
developments. Rather, parties actively and regularly exchange knowledge about campaign strategies, and even share concrete tools for national election campaigns. This exchange is not "restricted to second-order elections" in which there are "transnational endeavors in campaigning" by the Europarties (Tenscher et al., 2012, p. 159). Quite to the contrary, Europarties have taken up a role in orchestrating and stimulating processes of exchange of campaign strategies that exist also outside the organisation of the Europarty.

There is anecdotal evidence about expectation (1.2) that parties that newly seek to obtain government office have more incentive to engage in transnational party activities with a view to office-seeking. The findings about the 2013 and 2017 Bundestagswablen, however, do not clearly confirm or reject this expectation. Only two interviewees from the SPD explained that engaging in activities with sister parties to foster public legitimacy as a capable government party was more important when the party came from the opposition benches. They provided the examples of visits to and from sister parties in view of the 1998 and 2013 Bundestagswablen (interviews 27 and 34).

Second, with a view to the set of expectations about the existence of routes to obtain resources, the findings do not confirm expectation (2.1) that parties with many alternative networks or much in-house capacity to generate vote or office-seeking resources have less incentive to engage in transnational party activities. By contrast, the findings show that the party spending least on elections campaigns, the Left, generally attributed less importance to transnational party activities in the context of election campaigns than the party spending most, the SPD. This is particularly so concerning the resource of campaign expertise. One explanation of this may be the tendency of "parties with large budgets" to professionalise their campaigns for national elections more than smaller parties (Gibson \& Römmele, 2001, p. 37; Tenscher \& Mykkänen, 2014, p. 34). Moreover, as discussed above, parties with the in-house resources to develop their own campaigns and manifestos may still attribute high normative importance to collective positions and campaigns, and hence to transnational activities to develop these.

There is evidence to confirm expectation (2.2) that parties are more likely to engage in transnational party activities with successful vote or office-seeking sister parties. Both the SPD, the Greens and the Left brought in leaders of sister parties who had been electorally successful or occupied government office to their national party conferences. Also in view of transnational party activities with a view to campaign expertise, parties usually cooperated with those sister parties than ran successful campaigns. As one interviewee of the SPD argued concerning visits to the campaigns of the US Democrats, there was little use in visiting the remnants of a lost election (interview 31).

These findings confirm the argument of Böhmelt et al. (2016, p. 400) about policy learning. Namely, the electoral success of parties abroad serves as a useful "heuristic" to make decisions about with whom to interact. The current findings, however, do not confirm that this is also the case for electoral positions. With the exception of the historical example of the SPD in 1998, parties did not attribute much importance to transnational activities with a view to acquire electoral positions. Moreover, and in 
contrast to the argument that policy learning takes place from any successful foreign party (2016, p. 400), transnational exchanges on campaigns by far and large took place with ideologically similar, sister parties (see also Dolowitz, Greenwold \& Marsh, 1999). Several interviewees also stressed the importance of having similar party organisations and a similar culture of the political system to facilitate exchange. This may serve as another heuristic.

Third, the findings confirm expectation (3) that parties are more likely to seek cooperation through multilateral channels when ideological coherence within their party family is strong, while they are more likely to rely on bilateral cooperation when ideological coherence is weak. Most obviously, interviewees at the Left perceived a strong ideological fragmentation of their party family in the EU. Beyond disagreements about the future of European integration, shown also in the CHES data of section 6.2, this concerned conflicts about the appropriate behaviour of member parties of the PEL. As a result, in practice, transnational activities of the Left to develop collective electoral positions and strategies were limited. One interviewee also explained that bilateral contacts were important in view of contacts with sister parties about campaign expertise, because various larger sister parties are not a member of the PEL (interview 19). Also interviewees at the SPD brought up examples of ideological differences with sister parties. In their view, such differences limited the prospects for more substantial collective positions and campaigns. Hence, even when overall ideological coherence is strong, specific disagreements - such as about the role of Europarties or the Spitzenkandidaten may still inhibit multilateral cooperation on campaigns.

Finally, and as also the comparative analysis of the dossier on EUNAVFOR Med stresses, the findings of the study of this dossier alone do not allow for a conclusive answer about the importance of one system-level factor vis-à-vis another. Additionally, interviewees brought up an important alternative explanation for the degree to which they engaged in transnational party activities. That is, internal party dynamics may drive such activities. At the Left, some interviewees found that the European dimension of the party was not well developed, so that there was not much interest in material from the PEL or sister parties. At the SPD, one interviewee found that there was little internal awareness of EU elections. They hence used the PES manifesto and 'their' Spitzenkandidat as a catalyst for raising awareness within the own party organisation (interview 29). 


\section{Part III}

Discussion and conclusion 



\section{Chapter 7}

\section{Synthesis and theoretical reflection}

The theoretical framework of chapter 3 starts out with the observation that the development of theoretical approaches is an important first step to further investigate the relation between parties and their environment (Montero \& Gunther, 2002, p. 15). The Europeanisation approach is dominant in research about national parties in the EU environment (see Ladrech, 2002). But while the concept of Europeanisation importantly directs attention to the EU as a significant element of the environment of national parties, it does little to explain the nature of the active response of parties to the $\mathrm{EU}$ environment. In this dissertation, I proposed a resource-dependence perspective on transnational party activities in the EU to understand the transnational party activities of national parties.

In this final chapter of the dissertation, I evaluate this resource-dependence perspective in two ways. I first synthesize the findings from the exploratory study of the transnational party activities of the SPD, the Left and the Greens with a view to the two dossiers EUNAVFOR Med, and national and European election campaigns.41 I return to the general theoretical argument about what drives and what conditions transnational party activities in the EU. I evaluate both the expectations about the motivations to engage in transnational party activities and about the three sets of system-level factors that condition transnational party activities. I also reflect on the limitations of the case studies examined in this dissertation.

I then evaluate the suitability of Resource Dependence Theory as such to understand transnational party activities in the EU. By considering other research on inter-parliamentary and transnational party cooperation in light of the current framework, I reflect on the strengths of the resource-dependence perspective. In so doing, I also 
explore alternative or additional explanations. Ultimately, I find that the importance that parties ascribe to transnational party activities on a particular EU dossier depends most importantly on the position of parties in the national political system with regard to that dossier. I also argue that the 'bottom-up' resource-dependence perspective provides an understanding of transnational party activities in the EU that is more "systematic and precise” (Wry, Cobb \& Aldrich, 2013, p. 466) than the dominant, 'top-down' approaches to transnational party activities in the EU.

\subsection{Synthesis of the findings in light of the resource-dependence perspective on transnational party activities in the EU}

\section{Motivations to engage in transnational party activities}

What drives transnational party activities of national political parties in European Union affairs? Tables 21 and 22 summarise the findings of the case studies on EUNAVFOR Med and election campaigns, based on the theoretical expectations about the motivations of parties to engage in transnational party activities. The tables report on the overall evaluation of the findings of both case studies. From the comparison of the two dossiers, three findings stand out.

First, actual transnational party activities are driven most importantly by a need to effectively achieve party goals at the national level. In the dossier of EUNAVFOR Med, interviewees generally found political expertise about the positions of other decisionmaking actors in the EU the most important resource to obtain through transnational party activities. In the dossier of national and European election campaigns, interviewees emphasized the particular importance of transnational party activities to acquire campaign expertise about strategies and tools for election campaigns from sister parties.

This primary importance of transnational party activities for reaching party goals at the national level follows from the primary locus of party activities at the national level in the two dossiers. A basic premise of Resource Dependence Theory is that parties "transact" with external actors "to acquire needed resources" (Pfeffer \& Salancik, $2003[1978]$, p. 2). What these "needed resources" are, depends on the goals that organisations strive to obtain. With regard to EUNAVFOR Med, the most important goal was influence on the policy decision about the deployment of German troops in the national Bundestag. With regard to national and European election campaigns, the most important goal was to obtain votes from the German electorate. In view of this, it is only natural that the three parties attributed most importance to transnational party activities to manage resource dependencies related to their 'national' goals.

Second, transnational party activities to develop collective resources at the European level are driven mostly by a need to manage social demands, rather than by actual resource needs. Overall, the parties attributed more importance to activities to acquire collective resources in the dossier of election campaigns than in the dossier of EUNAVFOR Med. This can most importantly be explained by differences in the extent 
to which parties saw a need to respond to normative demands about appropriate policyseeking and vote-seeking behaviour in the context of the two dossiers respectively (Deephouse, 1996; Powell \& DiMaggio, 1991).

Table 21 | Evaluating the main expectations about the resource dependencies that motivate transnational party activities when it comes to party goals at the national level

\begin{tabular}{|c|c|c|c|c|c|}
\hline $\begin{array}{l}\text { Party } \\
\text { goals }\end{array}$ & Case study & Resource dependencies & SPD & the Left & Greens \\
\hline \multirow{2}{*}{$\begin{array}{l}\text { Electoral } \\
\text { success }\end{array}$} & \multirow{2}{*}{$\begin{array}{l}\text { National } \\
\text { and } \\
\text { European } \\
\text { election } \\
\text { campaigns } \\
(2013-2019)\end{array}$} & $\begin{array}{l}\text { Electoral positions input to } \\
\text { the national manifesto or } \\
\text { positions to use in } \\
\text { national debates }\end{array}$ & $\begin{array}{l}\text { Limited } \\
\text { importance }\end{array}$ & $\begin{array}{l}\text { No } \\
\text { importance }\end{array}$ & $\begin{array}{l}\text { Limited } \\
\text { importance }\end{array}$ \\
\hline & & $\begin{array}{l}\text { Campaign expertise } \\
\text { knowledge about effective } \\
\text { party campaigning }\end{array}$ & $\begin{array}{l}\text { Substantial } \\
\text { importance }\end{array}$ & $\begin{array}{l}\text { Some } \\
\text { importance }\end{array}$ & $\begin{array}{l}\text { Substantial } \\
\text { importance }\end{array}$ \\
\hline $\begin{array}{l}\text { Benefits } \\
\text { of office }\end{array}$ & $\begin{array}{l}\text { National } \\
\text { and } \\
\text { European } \\
\text { election } \\
\text { campaigns } \\
(2013-2019)\end{array}$ & $\begin{array}{l}\text { Public legitimacy public } \\
\text { perception a legitimate } \\
\text { government or opposition } \\
\text { party }\end{array}$ & $\begin{array}{l}\text { Some } \\
\text { importance }\end{array}$ & $\begin{array}{l}\text { Some } \\
\text { importance }\end{array}$ & $\begin{array}{l}\text { Some } \\
\text { importance }\end{array}$ \\
\hline \multirow{2}{*}{$\begin{array}{l}\text { Policy } \\
\text { success }\end{array}$} & \multirow{2}{*}{$\begin{array}{l}\text { European } \\
\text { Union Naval } \\
\text { Force } \\
\text { Mediterrane } \\
\text { an (2015- } \\
2018)\end{array}$} & $\begin{array}{l}\text { Political expertise knowledge } \\
\text { about preferences of EU } \\
\text { actors and national } \\
\text { governments }\end{array}$ & $\begin{array}{l}\text { Some } \\
\text { importance }\end{array}$ & $\begin{array}{l}\text { Some } \\
\text { importance }\end{array}$ & $\begin{array}{l}\text { Substantial } \\
\text { importance }\end{array}$ \\
\hline & & $\begin{array}{l}\text { Subject-matter expertise } \\
\text { knowledge about technical } \\
\text { and normative aspects of } \\
\text { EU dossiers }\end{array}$ & $\begin{array}{l}\text { No } \\
\text { importance }\end{array}$ & $\begin{array}{l}\text { Substantial } \\
\text { importance }\end{array}$ & $\begin{array}{l}\text { Some } \\
\text { importance }\end{array}$ \\
\hline
\end{tabular}

For EUNAVFOR Med, the perceived normative importance of collective political positions or strategies was low. Most interviewees stressed that the decision about the deployment of German troops to the operation was 'national' in nature. They thus considered the positions of sister parties, and any collective positions or strategies, of little relevance to the legitimacy of their national decision. This can be understood by the strong notion that the German troops are a 'parliamentary army' (Parlamentsarmee): only the Bundestag can decide about troop deployment (see e.g. Wagner, 2017). By contrast, for European election campaigns, the perceived normative importance of collective electoral positions and strategies was high. Interviewees referred to a need to be actively involved in the development of Europarty manifestos and campaigns, given the position of their parties in the EU and their support for European integration. This can be understood in light of the persisting "supranational European identity" of German political elites 
(Banchoff, 1999, p. 283), particularly at the left of the German political spectrum (Rohrschneider \& Whitefield, 2017).

Table 22 | Evaluating the main expectations about the resource dependencies that motivate transnational party activities when it comes to party goals at the European level

\begin{tabular}{|c|c|c|c|c|c|}
\hline $\begin{array}{l}\text { Party } \\
\text { goals }\end{array}$ & Case study & Resource dependencies & SPD & the Left & Greens \\
\hline \multirow{2}{*}{$\begin{array}{l}\text { Electoral } \\
\text { success }\end{array}$} & \multirow{2}{*}{$\begin{array}{l}\text { National } \\
\text { and } \\
\text { European } \\
\text { election } \\
\text { campaigns } \\
(2013-2019)\end{array}$} & $\begin{array}{l}\text { Collective electoral positions* } \\
\text { common election } \\
\text { manifesto and common } \\
\text { positions }\end{array}$ & $\begin{array}{l}\text { Substantial } \\
\text { importance }\end{array}$ & $\begin{array}{l}\text { Substantial } \\
\text { importance }\end{array}$ & $\begin{array}{l}\text { Substantial } \\
\text { importance }\end{array}$ \\
\hline & & $\begin{array}{l}\text { Collective electoral strategies* } \\
\text { common election } \\
\text { campaign and lead } \\
\text { candidates }\end{array}$ & $\begin{array}{l}\text { Substantial } \\
\text { importance }\end{array}$ & $\begin{array}{l}\text { Some } \\
\text { importance }\end{array}$ & $\begin{array}{l}\text { Substantial } \\
\text { importance }\end{array}$ \\
\hline \multirow{2}{*}{$\begin{array}{l}\text { Policy } \\
\text { success }\end{array}$} & $\begin{array}{l}\text { European } \\
\text { Union Naval }\end{array}$ & $\begin{array}{l}\text { Collective political positions } \\
\text { common policy positions } \\
\text { at the EU level }\end{array}$ & $\begin{array}{l}\text { Limited } \\
\text { importance }\end{array}$ & $\begin{array}{l}\text { Some } \\
\text { importance }\end{array}$ & $\begin{array}{l}\text { Some } \\
\text { importance }\end{array}$ \\
\hline & $\begin{array}{l}\text { Mediterrane } \\
\text { an (2015- } \\
2018)\end{array}$ & $\begin{array}{l}\text { Collective political strategies } \\
\text { access to EU decision- } \\
\text { making processes and } \\
\text { skills to steer negotiations }\end{array}$ & $\begin{array}{l}\text { No } \\
\text { importance }\end{array}$ & $\begin{array}{l}\text { Some } \\
\text { importance }\end{array}$ & $\begin{array}{l}\text { Some } \\
\text { importance }\end{array}$ \\
\hline
\end{tabular}

* Note that for these resource dependencies, the table reports on the 'symbolic' importance attributed to transnational party activities to seek these resources. Interviewees at the SPD and the Left considered actual activities to fall short of this importance. See chapter 6 , section 6.5 for a discussion.

Third, parties have to manage conflicting demands about transnational party activities. This most importantly concerns conflicts between demands 'at home' and demands from external actors 'abroad'. With regard to policy seeking, for example, interviewees had to juggle the need to attend inter-parliamentary meetings that are symbolically important and useful for networking, with the time constraints of daily work in the Bundestag - the latter forum clearly being more visible to voters than the former. With regard to vote seeking, for example, particularly the SPD had to juggle domestic demands about upholding the Spitzenkandidaten system and PES manifesto, with the preferences of sister parties in the EU.

\section{System-level factors that condition motivations to engage in transnational party activities}

Under what conditions do national political parties engage in transnational party activities in European Union affairs? Table 23 evaluates the main expectations about the systemlevel factors that condition transnational party activities in the EU. It synthesizes the findings of the exploration of the transnational activities of the SPD, the Left, and the Greens with a view to EUNAVFOR Med, and national and European election campaigns. The case studies confirm most of the expectations from the resource- 
dependence perspective of chapter 3. From the in-depth exploration of the activities of the three parties in the two dossiers, I can draw some further conclusions about the explanatory power of the three sets of conditions.

Crucially, whether parties ascribe importance to transnational party activities on a particular EU dossier is conditioned primarily by the position of parties in the national political system with regard to that dossier. This follows from the finding that transnational party activities are driven most importantly by a need to achieve particular party goals nationally. While both dossiers demonstrate the primary importance of domestic constellations, particularly the analysis of the policy-seeking behaviour in the dossier of EUNAVFOR Med serves to illustrate the importance of the specific constellations of domestic politics. Clearly, opposition parties the Left and the Greens ascribed more importance to transnational party activities than government party SPD. The type of resources that the two opposition parties sought after was furthermore conditioned by domestic strategies vis-à-vis the national government. That is, the Left ascribed most importance to subject-matter expertise, given its primary focus on the content of operation EUNAVFOR Med. By contrast, the Greens ascribed most relevance to political expertise, given its primary focus on decision-making processes about the military operation.

In turn, the ideological coherence of the party family is an important condition for the type or intensity of the transnational activities that parties engage in. It does not condition the motivation to engage in transnational party activities as such (see also Miklin, 2013, p. 36). The case of the Left within the dossier on election campaigns, for example, provides evidence of this dynamic. On the one hand, interviewees at the Left signalled an important need to develop collective positions in the radical left family. This emanated from their perceived 'European' responsibility. Yet on the other hand, ideological conflicts in its European party family meant that both the content and the extent of collective positions were limited in practice.

The comparison of the two dossiers also shows that the factor of ideological coherence is issue specific. This follows most clearly from the different practices of the SPD and the Left in the context of the two dossiers. In contrast to the issue of European election campaigns, on the issue of EUNAVFOR Med the radical left family was united in its position against a 'militarisation' of EU external borders. Multilateral activities of the German Left regarding the operation hence worked well. At the SPD, multilateral activities on EUNAVFOR Med did not work well, given ideological disagreements with sister parties. Such disagreements were more limited in view of common European election campaigns, in which the SPD did pursue various multilateral activities.

The presence of successful sister parties and of alternative networks that provide access to resources likewise most importantly conditions the type or intensity of transnational party activities, rather than the motivation to engage in transnational activities. For example, for all three parties, the exchange of campaign expertise was most intensive with sister parties that ran relatively successful campaigns. And in the 
EUNAVFOR Med dossier, interviewees from the Greens mentioned that transnational activities were limited by the small number of strong green parties in other national parliaments. For interviewees of the Left, personal contacts in NGOs were a more readily accessible external source of information than sister parties. Its comparatively good access to information, in turn, made the Left an important partner for its sister parties.

Finally, in-house capacities are not a straightforward condition on transnational party activities. Some findings show that the availability of in-house resources indeed conditions the incentive for transnational party activities. This most importantly concerns the finding that the three parties found transnational exchange of electoral positions of little relevance to their national election campaigns. Instead, interviewees explained that electoral positions are sought after by sister parties that do not have the in-house resources to develop their own positions (see also Van Haute, 2016a, p. 320). Yet findings on other resource dependencies show a different dynamic. Most notably, despite having a very large central party office, interviewees of the SPD ascribed substantial importance to transnational party activities to exchange campaign strategies (see Gibson \& Römmele, 2001, p. 37; Tenscher \& Mykkänen, 2014, p. 34).

\section{The 'provisional character' of the case-based explanations}

Importantly, the conclusions about the resource-dependence perspective on transnational party activities are tentative. The "provisional character [of] theoretical conclusions" is inherent not just to the exploratory nature of this research project, but also to explanations based on a small number of case studies in general (George \& Bennett, 2004, p. 90-91). Most importantly, given that I compare only few political parties, but study a wider range of explanatory factors, I cannot be certain about the explanatory power of each system-level condition relative to other conditions. The combination of the across-case comparison with insights from within the cases addresses part of this problem. However, several limitations to the theoretical conclusions remain.

For example, the focus on the dossiers of EUNAVFOR Med and election campaigns may lead to an overestimation of the importance of conditions on transnational party activities in the EU that emanate from domestic politics. That is, the party goals in both dossiers are clearly located at the national level. When transnational party activities are pursued primarily with a view to national party goals, it is only to be expected that domestic political constellations are an important condition on these activities. Should the party goals of a particular EU issue be more clearly located at the European level, domestic political constellations may be less important. At the same time, however, the findings on EUNAVFOR Med do show that the parliamentary opposition parties also had more incentive to pursue party goals at the European level through collective positions and strategies. This was because they could not reach their policy goals at the national level. 
Table 23 | Evaluating the main expectations about the system-level factors that condition transnational party activities

\begin{tabular}{|c|c|c|c|}
\hline Set of expectations & Expectation & Case study & Evaluation \\
\hline \multirow{2}{*}{$\begin{array}{l}\text { Position in the } \\
\text { national political } \\
\text { system }\end{array}$} & $\begin{array}{l}\text { (1.1) Parties that face a changing electorate have more } \\
\text { incentive to engage in transnational party activities (vote- } \\
\text { seeking) }\end{array}$ & $\begin{array}{l}\text { National and European election } \\
\text { campaigns (2013-2019) }\end{array}$ & $\begin{array}{l}\text { Findings confirm this } \\
\text { expectation }\end{array}$ \\
\hline & $\begin{array}{l}\text { (1.3) Opposition parties have more incentive to engage in } \\
\text { transnational party activities than government parties (policy- } \\
\text { seeking) }\end{array}$ & $\begin{array}{l}\text { European Union Naval Force } \\
\text { Mediterranean (2015-2018) }\end{array}$ & $\begin{array}{l}\text { Findings confirm this } \\
\text { expectation }\end{array}$ \\
\hline \multirow{2}{*}{$\begin{array}{l}\text { Existence of } \\
\text { (alternative) } \\
\text { routes to obtain } \\
\text { resources }\end{array}$} & $\begin{array}{l}\text { (2.1) Parties with many alternative networks or much in- } \\
\text { house capacity to generate resources have less incentive to } \\
\text { engage in transnational party activities }\end{array}$ & Both case studies & $\begin{array}{l}\text { Findings partially confirm } \\
\text { and partially reject this } \\
\text { expectation }\end{array}$ \\
\hline & $\begin{array}{l}\text { (2.2) Parties are more likely to engage in transnational party } \\
\text { activities with sister parties that have relevant access to } \\
\text { resources }\end{array}$ & Both case studies & $\begin{array}{l}\text { Findings confirm this } \\
\text { expectation }\end{array}$ \\
\hline $\begin{array}{l}\text { Ideological } \\
\text { coherence of the } \\
\text { party family }\end{array}$ & $\begin{array}{l}\text { (3) Parties are more likely to seek cooperation through } \\
\text { multilateral channels when ideological coherence with their } \\
\text { party family is strong, while they are more likely to rely on } \\
\text { bilateral cooperation when ideological coherence is weak }\end{array}$ & Both case studies & $\begin{array}{l}\text { Findings confirm this } \\
\text { expectation }\end{array}$ \\
\hline
\end{tabular}


Moreover, the focus on the SPD, the Left, and the Greens may lead to an underestimation of the importance of transnational party activities with a view to establishing a network of sister parties. That is, the three German parties all occupy strong positions within their party families. They maintain often long-standing bilateral connections to sister parties and occupy key posts within their respective Europarties. Political parties that do not have such an established 'coalition of support' (March \& Simon, 1958; see Pfeffer \& Salancik, 2003[1978], p. 24-27) may undertake more substantial 'symbolic' activities to establish stronger relationships with sister parties or Europarties.

Indeed, and relatedly, I cannot draw conclusions about the resource dependencies of procedural expertise and access to collective parliamentary and party resources that the resource-dependence perspective on transnational party activities in the EU also identifies. With regard to the access to collective resources, I did not cover any newly established parties that are aligned with a Europarty or EP party group yet. This means that the study does not provide insights into transnational party activities with a view to becoming accepted as a member of a party group in the European Parliament and European political party (Bressanelli, 2012; Whitaker \& Lynch, 2014). With regard to procedural expertise, the exploration of the SPD, the Left and the Greens did not find evidence about transnational activities to acquire knowledge on EU policy making procedures (Crum \& Fossum, 2013; Hefftler, 2015; Miklin, 2013). This is most likely because the German parliamentary parties could rely on their in-house expertise, as well as on the strong expertise of the Bundestag on EU affairs (see Höing, 2015).

\section{2 | Theoretical reflection: Other approaches to transnational party activities in the EU in light of the resource-dependence perspective}

Since Pfeffer and Salancik developed Resource Dependence in the 1970s, organisations have grown more interconnected in view of globalisation of economies and political processes and systems. This is not least the case for the system of multilevel governance in the European Union. Clearly, the EU environment "entails a level complexity" that goes well beyond what Pfeffer and Salancik originally theorised (Wry et al., 2013, p. 444). Yet as I have argued in chapter 3, the focus of RDT on how organisations perceive and manage environmental complexity makes the approach highly suitable to study the interorganisational activities of organisations in the EU (see also Beyers \& Kerremans, 2007; Bouwen, 2002; Fonck, 2018; Vantaggiato, 2019; Vestlund, 2017).

In particular, I contend that the "bottom-up approach" of RDT provides a "more systematic and precise" understanding of the complexity that national parties face in the EU than existing, mostly "top-down" approaches to this complexity (Wry et al., 2013, p. 466). In the following, I first discuss existing research that takes a top-down approach to transnational party activities in the EU in light of the RDT perspective. I subsequently 
discuss the few existing bottom-up approaches to transnational party activities in light of RDT.

\section{Top-down approaches to transnational party and inter-parliamentary cooperation vis-à-vis RDT}

In the literature on inter-parliamentary and transnational party cooperation in the EU, 'top-down' approaches are dominant. Conceptually, these approaches study complexity at a level 'above' that of national parties themselves, including at institutional fields, governance systems, and networks. They subsequently study the competing demands on political parties that arise from the dynamics of these higher-level structures (see Wry et al., 2013, p. 466-467).

For example, Crum and Fossum (2009, p. 251) conceptualise the complex structure of democratic representation in the EU in terms of a 'multi-level parliamentary field'. This 'field' consists of "institutions and norms that serve the coordination of the EU's constituent parliaments" (p. 260). The interests of the national parliaments and the EP are "defined by virtue of their position in the field in relation to the other [parliaments]" (p. 260). Given this approach, the multi-level parliamentary field directs attention to the "character and density of inter-parliamentary interaction" (p. 262) in the context of overarching decision-making areas (e.g. Herranz-Surrallés, 2014).

Likewise, the Europeanisation approach is primarily concerned with conceptualising the complexity of the EU environment as part of the "operating arena" of national parties (Ladrech, 2002, p. 395; Carter, Luther \& Poguntke, 2007, p. 6-8). Europeanisation then aims to "trace [how] an EU source" leads to changes in national parties (Ladrech, 2002, p. 396). Studies adopting a Europeanisation perspective on transnational party cooperation hence focus on the influence of Europarties on national parties (e.g. Hertner, 2011; Von dem Berg \& Poguntke, 2013). Adopting a somewhat different perspective, accounts of transnational party cooperation based on transnational approaches conceptualise complexity at the level of networks between party elites and of Europarties. In this perspective, the multi-level system of governance of the EU is characterised by "complex actor constellations" and "informal political infrastructures" (Salm, 2016, p. 8). The researcher, then, maps transnational networks and assesses their functioning and impact (p. 9; see also Johansson, 2017; Lightfoot, 2005).

Clearly, these approaches provide important insights into the higher-level norms and institutional or network dynamics that are important for understanding interparliamentary and transnational party cooperation in the EU. Nevertheless, the 'topdown' approaches provide little analytical leverage to link environmental complexity to the actual choices and behaviour of different national parties in engaging in transnational contacts (Wry et al., 2013). Rather, the approaches mostly presume that national parties will take part in transnational networks, Europarties, or inter-parliamentary conferences when they have the material interests and the resources to do so (Beyers \& Kerremans 2007, p. 464). 
By contrast, the resource-dependence approach to transnational party activities analyses complexity not as originating from 'fixed' institutional settings, but from the perspective of individual national parties. In other words, its analytical starting point is that of parties themselves. RDT also treats environmental complexity as changing depending on the issue at hand. It is sensitive to how environmental constellations, and thus responses of political parties, are different both over time and in the context of different EU issues. The findings of the exploratory study of the two dossiers in this dissertation clearly illustrate this. All in all, the shift from a 'top-down' to a 'bottom-up' perspective may seem small, but it "help[s] scholars to clarify both the source and level of complexity surrounding particular issues and decisions" (Wry et al., 2013, p. 468).

Indeed, the resource-dependence perspective on transnational party activities in the EU helps to understand the conclusions of top-down approaches to transnational party cooperation. The most common finding of transnationalism and the Europeanisation approach is that the influence of Europarties and transnational networks is in fact limited by domestic political constellations. Studying the PES, Lightfoot (2005), for example, finds that "domestic policy imperatives and ideological differences between the member parties hindered the development of a true policy-seeking [Euro]party" (p. 2). Studying the EPP, Johansson (2016) finds that "national arenas of politics constrain [national] parties and therefore serve to limit the scope for [Europarty influence]" (p. 81). And one of Salm's (2016) conclusions from the study of socialist party networks is that "the political ambitions of the various socialist network actors involved [...] strongly reflected domestic and intra-party conflicts" (p. 161). These findings are clearly in line with the argument of this dissertation that transnational party activities are conditioned most importantly by the position of parties in the domestic political system.

Yet problematically, the primary concern of transnationalism and the Europeanisation approach is to theorise about how Europarties or transnational party networks influence EU decision-making (e.g. Johansson, 2017; Lightfoot, 2005; Salm, 2016). To nevertheless facilitate a consideration of domestic factors, some scholars attempt to combine their top-down approach with insights from Comparative Politics (Johansson, 2004; Timuş, 2014). However, the empirical analysis, and thus the further development of theory, remains primarily concerned with assessing Europarty influence. Domestic politics, then, is understood as a 'limit' or 'constraint' on such influence (e.g. Johansson, 2016). By contrast, RDT provides a tool to identify the domestic demands on political parties more systematically and carefully. This includes a consideration of how domestic constellations may drive rather than constrain transnational party activities and of how national parties manage discrepancies between domestic demands and demands from sister parties.

The resource-dependence perspective also helps to go beyond overarching analyses of the character of inter-parliamentary relations at the EU level. For example, Herranz-Surrallés (2014) finds that the field of inter-parliamentary cooperation in CFSP/CSDP is characterised by a "mismatch between the formal constitutional authority 
and the actual parliamentary capital" of national parliaments and the EP (p. 961). This mismatch has led national parliaments and the EP to make competing demands about their authority in CFSP/CSDP decision making. Yet whereas the "logic" (Wry et al., 2013) of the mismatch may indeed be the prime cause of competing demands, the complexity that it creates is likely to be different for different parliaments. Indeed, Herranz-Surrallés (2014, p. 969) shows that national parliaments held different preferences even when the mismatch was particularly severe. A resource-dependence perspective would further clarify the importance of the mismatch for particular parliamentary actors in the context of the other environmental demands that they face. It would also help to understand the relevance of the mismatch in the context of different political issues (see Wry et al., 2013, p. 468-470).

\section{Other bottom-up approaches to transnational party and inter-parliamentary cooperation vis-à-vis $\mathrm{RDT}$}

There are very few scholars who have previously developed a 'bottom-up' theoretical approach to transnational party activities in the EU. Most notably, Hanley (2008; see also Külahci, 2010) employs principal-agent theory to understand the relationship between national parties and Europarties. He conceptualises national parties as 'principals' that delegate a number of functions to Europarties as 'agents'. National parties will subsequently seek to control the autonomy of these agents (p. 25). An important strength of principal-agent approach is that it does not pre-suppose that Europarties will naturally become more powerful with further European integration. Instead, and much like RDT, the approach directs attention to the motives of parties to delegate certain capacities to Europarties (p. 23).

Indeed, the findings of Hanley's study on the development of Europarties in different party families can be incorporated in the resource-dependence perspective on transnational party activities in the EU. That is, Hanley argues that national parties delegate certain "functions" to Europarties. These functions include the "exchange of information, meetings of elites, elaboration of possible policy options and concertation of action, where necessary, in European international fora" (p. 202). He also underlines that the "identity-related function" of Europarties - namely, the source of public and organisational legitimacy that Europarties provide - is a crucial "political good" for national parties (p. 202). Clearly, these functions bear very strong similarity to the resources identified in the resource-dependence framework of the current dissertation.

Also Hanley's key argument that national parties prefer to create "weak" Europarties, with little power to dictate the behaviour of its members, can be understood from a resource-dependence perspective. As discussed in chapter 3 of this dissertation, RDT posits that organisations seek to limit a loss of autonomy, in so far as giving up autonomy creates power imbalances and is not necessary to manage access to resources and maintain a coalition of support (Oliver, 1991, p. 943). 
Ultimately, however, Hanley concludes that beyond the general preference for weak Europarties, "it is surprising how differently some national parties can use their [Europarty] and what ambitions they may have for it" (p. 204). The principal-agent model cannot account for this diversity, as it simply assumes that national parties want to delegate functions to Europarties when benefits outweigh costs (Hanley, 2008, p. 25). Moving beyond his initial principal-agent model, Hanley thus goes on to propose an "explanatory schema as a first, tentative step to understanding [the] very wide range of national approaches" (p. 204). Based on his empirical findings, he proposes that the relative size of national parties, the presence of well-established bilateral ties, and domestic government or opposition status are key factors to understand the diverse preferences of national parties in transnational party activities (p. 206-210).

Clearly, the resource-dependence perspective incorporates these factors in the analysis of the preferences of national parties in engaging in transnational activities at the outset already. While principal-agent theory analytically 'zooms in' on the specific exchange relation between Europarties and national parties only, RDT directs attention to the overall embeddedness of political parties in their environment. It is this environmental embeddedness that provides the context to understanding the relation between Europarties and national parties, and, as such, to understanding the different demands of national parties towards Europarties over time and in different EU dossiers (see also Beyers \& Kerremans, 2007). Hence, Hanley's (2008, p. 206) finding that national parties have very different perceptions of their "own interests" to engage in transnational party activities follows much more naturally from the resource-dependence perspective.

Finally, the resource-dependence perspective can also accommodate some of the hypotheses formulated about transnational party activities that have not been grounded in a comprehensive theoretical perspective. Miklin (2013), for example, essentially formulates a resource-dependence argument when he states that transnational party cooperation provides national parties with the "functions" of access to information and coordination. He notes that opposition parties cannot count on the government to performs these functions and that the ability to engage in cooperation requires a degree of ideological coherence with sister parties. Hence, parties engage in cooperation depending on "their status within the parliament (whether they are in government or in opposition) and the objectives they pursue (their ideology)" (p. 26).

However, Miklin goes on to assess the overall frequency of national parties' engagement in transnational party activities, as do scholars who assess similar hypotheses on the basis of attendance data of inter-parliamentary conferences (Gattermann, 2014; Malang, 2019; Wagner, 2013). RDT, however, cautions that complexity is "episodic" (Wry et al., 2013, p. 467). Hence, how national parties manage their resource dependencies is not fixed by their location in the institutional system. Rather, transnational party activities should be understood "by examining what's at stake [...] in a given situation" (p. 467). Indeed, Miklin (2013) finds that the bilateral contacts of parties are "mainly issue-driven" (p. 31). He brings up one example of this when he discusses the substantial transnational 
contacts of the SPÖ in view of the EU Services Directive (p. 34). As the approach of the current dissertation shows, the resource-dependence perspective allows for a more encompassing consideration of the various factors that lead national parties to search transnational contacts in such particular situations. It also allows for a more systematic consideration of 'functions' or resources of transnational party cooperation other than those of coordination and information only. 



\section{Conclusion}

The aim of this dissertation is to better understand the transnational party activities of national parties in the European Union, both theoretically and empirically. The introduction presents the puzzle about such activities. That is, on the one hand, national parties have strategic opportunities to engage in transnational party activities. These opportunities arise from the nature of multi-level decision making in the European Union. On the other hand, national parties face domestic constraints in making use of such opportunities. These constraints include both practical constraints, such as the availability of time and money, and political constraints, such as the generally low salience of European affairs to domestic voters.

The review of the historical development of different avenues to transnational party activities in chapter 1 further problematises this puzzle. The constellation of institutional platforms for inter-parliamentary and transnational party cooperation in the EU is complex. Platforms have different memberships and purposes and have also grown increasingly interconnected. Chapter 2 shows that the academic literature so far addresses this constellation from a 'top-down' perspective. Scholars by far and large study the functioning of formal forms of cooperation, such as inter-parliamentary conferences and Europarties. The questions remain when national parties make use of the opportunities for transnational activities that exist and what the informal transnational activities of national parties look like.

This dissertation thus studied transnational party activities from a 'bottom-up' perspective. It studied the choices that national parties make in their interaction with sister parties in the EU. I relied on Resource Dependence Theory to develop a new, theoretically informed perspective on transnational party activities in the European Union. I subsequently explored the plausibility of this perspective through a qualitative analysis of the transnational activities of the SPD, the Left and the Greens - the three parties on the left of the political spectrum in the German Bundestag. I studied their transnational activities with a view two cases, namely the EU naval operation EUNAVFOR Med that was launched in 2015, and the national and European elections between 2013 and 2019. I relied on semi-structured interviews with forty politicians and 
staff members, as well as on an analysis of various primary sources to triangulate the interview findings.

In this conclusion, I first briefly summarise the findings of the dissertation to answer the two research questions set out at the start. I subsequently discuss the normative implications of these findings in light of the debate about the democratic legitimacy of the EU and the role of national parties therein. Finally, I present an agenda for future research on transnational party activities in the EU.

\section{With a little help from our friends: Why national parties (don't) engage in transnational party activities in EU affairs}

The introduction to this dissertation sets out two research questions, namely what drives transnational party activities of national political parties in European Union affairs? and under what conditions do national political parties engage in transnational party activities in European Union affairs? The former question asks about the motivations of national parties to engage in transnational party activities, while the latter question concerns the system-level factors that impact on these motivations.

As chapter 7 discusses, the answers to both questions point to the importance of domestic constellations. Transnational party activities on EU affairs are driven most importantly by resource dependencies that result from a desire to effectively achieve a certain party goal at the national level. In turn, transnational party activities are most importantly conditioned by the position of a party in the national political system with regard to that goal.

Put differently, it is clear that political parties and parliamentarians engage in 'multi-level games' on EU affairs with their 'friends' in the EU. That is, sister parties in the EU can be friends to rely on not just to advance goals at the European level, but also to advance goals at the national level. 'With a little help from their friends', parties acquire knowledge, skills, or status that strengthens their position nationally. In turn, parties also provide their friends with such benefits.

The finding that this is the case even in matters of EU affairs may seem counterintuitive at first sight. One may think that having allies within the EU arena is beneficial primarily to pursue goals at the level of the EU. The finding is more obvious, however, in the context of the contuining importance of the national level of democratic representation in the EU's system of governance. As Johansson (2004) writes, "[t]he nature of party politics at the European level can no more be understood without reference to domestic party politics than EU policymaking can be explained without reference to political processes within the member states" (p. 26).

Various other causes of and conditions for transnational party activities in the EU, however, also come into play. Crucially, in particular transnational party activities to develop collective strategies or positions can also be driven by considerations about transorganisational and public legitimacy. Especially parties that adopt a favourable attitude 
towards European integration can perceive it as their duty to 'act European' on a particular EU dossier and can find that transnational party activities are important to reinforce their legitimacy in the eyes of the national electorate. At the same time, the perception that there is normative importance to the 'national' nature of a particular EU dossier can mean that national parties do not ascribe much relevance to transnational party activities.

The resource-dependence perspective that this dissertation develops furthermore directs attention to the changing character of national parties' engagement in transnational party activities in the EU. While it is clear that there are overarching factors that condition transnational party activities in the EU, such factors play out differently depending on the particular issue at stake (see also Wry, Cobb \& Aldrich, 2013, p. 467). Most importantly, whether a party has similar or different ideological views in the context of a particular dossier is an important condition on the type or intensity of transnational activities that a party engages in. Ideological coherence does not, however, condition the motivation to engage in transnational party activities as such.

The existence of (other) routes to obtain resources likewise conditions the type or intensity of transnational party activities. This especially concerns the presence of inhouse resources, the existence of personal contacts with external actors, and the availability of successful sister parties. It is hence very important to consider the transnational party activities of national parties in the context of relations to other actors than sister parties and Europarties only (see also Beyers \& Kerremans, 2007).

\section{Limits, potentials and threats for transnational party activities in the EU}

The findings from the exploration of the transnational party activities of the SPD, the Left and the Greens have a number of normative implications for the debate about the democratic legitimacy of the EU. National parties continue to play a crucial role in the democratic system of the EU (e.g. Bellamy \& Kröger, 2014; Lindberg, Rasmussen \& Warntjen, 2008). This is not least because the European Parliament does not have an equal say to the Council of Ministers in all EU decisions and because the Europarties have little capacity to contest EU policy issues. But perhaps more importantly, national parties and parliaments remain more well-known and visible to citizens than the Europarties or the EP.

The topic of this dissertation speaks to three 'aspirations' in the academic literature on the democratic involvement of national parties and parliaments in the EU.42 These are, first, that Europarties and inter-parliamentary conferences may enhance the role of national parties and parliaments (e.g. Crum \& Fossum, 2013b; Külahci \& Lighfoot, 2014; compare Raunio, 2009). Second, that national parties may engage in more partisan 
contestation of EU affairs, which would contribute to a more developed democratic debate about EU affairs (e.g. De Wilde \& Zürn, 2012; Hefftler, 2018; Van Middelaar, 2016). And third, that national parties may increase their influence in EU affairs by relying on informal sources of information and participation (e.g. Mello \& Peters, 2018; Miklin, 2013; Salm, 2016). What do the findings of the case studies on transnational party activities with a view to EUNAVFOR Med and election campaigns imply about these aspirations?

First, the resource-dependence approach illustrates the limitations of platforms for party and inter-parliamentary cooperation. This raises doubts about the degree to which inter-parliamentary conferences and Europarties may actually address a lack of democratic involvement of parties in EU affairs. Most importantly, the mere existence of Europarties and inter-parliamentary conferences is not sufficient for them to become centres of individual parties' transnational activities (cf. Crum \& Fossum, 2013a; Raube, MüftülerBaç \& Wouters, 2019). The findings show that this is particularly the case for the interparliamentary conference for the CFSP/CSDP. Granted, the conference comes with resource benefits, including access to information about different political positions towards an EU policy dossier. Yet at the same time, its functioning is uncertain and its symbolic value is low. To acquire resources related to policy-seeking on EU affairs, parties may thus prefer to rely on other, often domestic, actors to which they have longstanding relationships (see also Beyers \& Kerremans, 2007, p. 464).

It is pressing to address the limited potential of the IPC CFSP/CSDP, because governments increasingly seem to integrate their defence and security policies in the EU. The initiation of PESCO in 2017, for example, involves binding commitments to further integrate defence capabilities. To enhance the involvement of parties in parliamentary office in EU security and defence, it can be worthwhile to strengthen the organisation of the IPC CFSP/CSDP along the lines of party families. Meetings with sister parties provide an avenue to coordinate positions in the short run, and to enhance mutual understanding and facilitate networks in the long run. This potential, however, would remain small for smaller opposition parties in the EU. Moreover, so long as the IPC CFSP/CSDP continues to have few formal capabilities, also party family meetings are bound to remain of limited value added. It may be more promising for Europarties and EP party groups to invest in stronger links between parliamentarians on security and defence committees. To level the playing field, this would require upgrading the security and defence in the EP from a subcommittee into a full committee (see Herranz-Surrellés, 2019, p. 37-38).

Second, the finding that transnational party activities are more important to opposition than to government parties lends support to more optimistic assessments about the involvement of opposition parties in EU affairs (e.g. Hefftler, 2018; Karlsson \& Persson, 2018). Opposition parties can make use of their contacts to the EP and to sister parties to strengthen their position vis-à-vis the government (see also Miklin, 2013). There is also evidence that parties actively foster common positions with sister parties and 
attempt to influence the debate about EU affairs across borders. Particularly for the leftwing opposition parties, these transnational activities are motivated by an awareness that they 'cannot go it alone' when they demand a different course of action on EU matters. This supports the idea that there is a transnational dimension to debates about European issues (Kinski \& Crum, 2019). At the same time, the findings also show that transnational party activities to acquire resources for domestic purposes are more important than activities to contest EU affairs across borders. This is in line with previous findings that EU affairs are debated primarily in terms of national interests (e.g. Wendler, 2018).

Third, the bottom-up approach of this dissertation shows that national parties need informal networks to act transnationally in the European Union, beyond formal avenues for cooperation (see also Salm, 2016). The creation of these networks crucially depends on the initiative of MPs, MEPs, and staff in parliamentary and central party office. Once established, informal networks can provide resources both for party goals in the national and the European realm. Of course, one may question if such informal contacts are 'good' or 'bad' in the context of democratic processes (see Christiansen \& Neuhold, 2013, p. 1201-1203). Importantly, however, informal contacts can strengthen the abilities and capacities of national parties, such as with respect to scrutinising the national government in EU affairs and adapting to electoral changes in the modern society.

In light of the importance of informal contacts, a high turnover of parliamentarians in national parliaments and the EP can be problematic. Notably, the 9th EP has the highest turnover of MEPs in history: 61\% of MEPs are new (European Parliament, 2019). Turnover may be even higher within certain parliamentary committees, as Herranz-Surrallés, for instance, shows for the EP's SEDE committee (2019, p. 38-38). In many national parliaments in the EU, legislative turnover has modestly increased, particularly since the 1990s (Verzichelli, 2019). Also the nineteenth Bundestag, elected in 2017, saw the highest percentage of MPs that entered the parliament for the first time since 1990, namely 37\% (Deutscher Bundestag, 2019). Although newly elected MEPs and MPs may bring established networks, they may not have substantial experience with the legislative area to which they are assigned. Given that it takes substantial amounts of time and resources to establish relationships based on mutual trust and familiarity (see also Costa, 2018a), high parliamentary or staff turnovers make the existence of informal networks fragile.

\section{Directions for future research on transnational party activities in the EU}

The increasing politicisation of EU affairs and the changing interconnectedness of different levels of governance provide national parties with strategic opportunities. There are a number of promising methodological, theoretical and empirical directions in which to further study the ways in which national parties make use of these opportunities. 
Methodologically, future research should study transnational party activities in other cases. First, there is a need to explore the transnational party activities of parties with fewer in-house resources, and weaker institutional capacity and powers of control in EU affairs. This would allow for a better understanding of the relationship between political parties' domestic capacities and their activism in transnational activities. Small parties may stand to gain most from transnational party activities, but they are also likely to have too few resources to actively participate in party networks. The study of mediumsized parties is thus most promising. They do not have access to all the resources they need, but do have the capacity to engage in transnational contacts (see Vantaggiato, 2019, p. 1541). In this respect, the study of the activities of right-wing populist parties may be particularly intriguing, as the Euroscepticism of these parties does not allow them to easily develop networks at the European level (see e.g. Startin \& Brack, 2016).

Second, there is a need to explore transnational party activities in other policy dossiers and areas. This would provide more insight, for example, into the relation between transnational activism and public salience, or between transnational activism and the nature of EU decision making - that is, supranational or intergovernmental.

A promising methodological approach to study such other cases is to draw on social network analysis. Data could be based on surveys or structured interviews about the informal contacts of MPs, MEPs, and staff members. Social network analysis, then, can provide insights into the 'density' and the 'connectedness' of networks (see Scott \& Carrington, 2011). This allows for describing differences in the strength of networks of different political parties and in different policy dossiers. Social network analysis also allows for the identification of key actors, as well as for insights into the direction of contacts and the strength of ties between actors (see e.g. Granovetter, 1973). Nevertheless, because transnational party activities can be politically sensitive, more open, unstructured, or semi-structured interviews with party elites remain important. Interviews are also key to understand the importance of the symbolic dimension of engagement in party families.

Theoretically, there is potential to further theorise about the motivations of individuals within party organisations to engage in transnational party activities. The dissertation provides anecdotal evidence about how individuals can use transnational activities to 'force' matters within their national party organisations. For example, interviewees discussed how the Europarty manifesto could be used to raise awareness about European elections within a party and how campaign expertise of sister parties could help to push forward on new campaign strategies internally. Clearly, the resourcedependence perspective on transnational party activities in the EU is sensitive towards different resource needs of individuals within political parties. Ultimately, however, it seeks to explain party behaviour in the face of external actors, including the national government and the electorate. At the level of individuals within political parties, other factors may drive and condition the willingness to engage in transnational interaction, such as internal power struggles (Costa 2018a, p. 6). 
In this respect, one promising direction for future research is to draw on boundary-spanning theory. Boundary spanners are those members of staff and politicians who link the party to outside organisations, interact with those organisations, and diffuse knowledge or experiences within the own organisation. In the context of political parties, international secretaries, for example, perform the role of boundary spanner (see also Salm, 2016). Yet boundary-spanning roles can also be assumed by party actors who are not assigned with such roles per se, such as 'ordinary' MPs and staff members. Boundaryspanning theory, then, helps to address questions about which organisational roles facilitate transnational party activities, under what conditions individuals take up these roles, and how individuals wield power within the party organisation through boundary spanning roles (see e.g. Davis \& Stazyk, 2015; Tushman \& Scanlan, 1981). This approach to transnational party activities in the EU would tie-in well with the resurgence of interest in the analysis of the roles that MPs take on in national parliaments (see Blomgren \& Rozenberg, 2015).

Empirically, there is a need to consider the informal, 'behind the scenes' activities of national parties in EU affairs more systematically. This has also previously been advocated, such as with respect to coordination between national parliaments as institutional actors (Christiansen \& Neuhold, 2013), to the role of parliamentary parties in decision making about security policy (Mello \& Peters, 2018), and to transnational cooperation between national parties (Salm, 2016). There is nevertheless still very little evidence about such informal processes. This is problematic, because an assessment of national parties' involvement in EU affairs based on the study of formal routes provides an incomplete picture of parties' actual strengths and weaknesses.

Moreover, there is a need to more systematically consider the various 'arenas' for the engagement of national parties in relation to each other. The large majority of existing research studies transnational party activities at the levels of inter-parliamentary platforms, in EP party groups, or in Europarties. Yet, as the findings of this dissertation show, these arenas are related and interconnected - even more so than formal structures for cooperation suggest (see also Miklin, 2013). This requires a bottom-up approach that starts with the motives of national parties to engage in transnational party activities. To take this a step further, future research should also explore the transnational engagement of national parties in EU affairs beyond the parliamentary and party arenas. That is, national parties also engage with actors such as citizens' movements, NGOs, and research institutions on EU affairs. What role do national parties play in such activist networks on EU affairs? And how do they link such networks to debates and decisions in national parliaments (see also Kinski \& Crum, 2019)?

In sum then, the findings of this dissertation show that further empirical research is necessary to understand the ways in which national parties manage the discrepancy between their predominantly national organisation and the increasingly European nature of political decisions (Burnell \& Gerrits, 2010, p. 1071-1072). Because cooperation and exchange with sister parties provide a way to make use of the opportunities that the multi- 
Conclusion

level system of governance of the EU provides, they provide one important avenue to manage this discrepancy. 


\section{References}

Abedi, A. (2002). Challenges to established parties: The effects of party system features on the electoral fortunes of anti-political-establishment parties. European Journal of Political Research, 41(4), 551-583.

Aldrich, H. \& Herker, D. (1977). Boundary spanning roles and organization structure. Academy of Management Review, 2(2), 217-230.

Allern, E.H. (2010). Political Parties and Interest Groups in Norway. Colchester: ECPR press.

Angelucci, D. \& Isernia, P. (2019). Politicization and security policy: Parties, voters and the European Common Security and Defense Policy. European Union Politics. https://doi.org/10.1177/1465116519851193

Anheier, H.K. (2001). Foundations in Europe: A comparative perspective. Civil Society Working Paper, 18. Retrieved from http://eprints.lse.ac.uk/8498/1/CSWP18-revised_july_2001.pdf

Auel, K. (2007). Democratic accountability and national parliaments: Redefining the impact of parliamentary scrutiny in EU affairs. European Law Journal, 13(4), 487-504.

Auel, K. \& Benz, A. (2005). The politics of adaptation: The Europeanisation of national parliamentary systems. The Journal of Legislative Studies, 11(3-4), 372-393.

Auel, K., Eisele, O. \& Kinski, L. (2018). What happens in parliament stays in parliament? Newspaper coverage of national parliaments in EU affairs. Journal of Common Market Studies, 56(3), 628-645.

Auel, K. \& Höing, O. (2015). National parliaments and the Eurozone crisis: Taking ownership in difficult times? West European Politics, 38(2), 375-395.

Auel, K. \& Raunio, T. (2014). Introduction: Connecting with the electorate? Parliamentary communication in EU affairs. The Journal of Legislative Studies, 20(1), 1-12.

Auel, K., Rozenberg, O. \& Tacea, A. (2015). To scrutinise or not to scrutinise? Explaining variation in EU-related activities in national parliaments. West European Politics, 38(2), 282304.

Aylott, N. (1997). Between Europe and unity: The case of the Swedish social democrats. West European Politics, 20(2), 119-136.

Aylott, N. (2007). A long, slow march to Europe: The Europeanization of Swedish political parties. In T. Poguntke, N. Aylott, E. Carter, R. Ladrech \& K.R. Luther (Eds.), The Europeanization of National Political Parties: Parties and Organizational Adaptation (pp. 149-174). London: Routledge.

Aylott, N., Blomgren, M. \& Bergman, T. (2013). Political Parties in Multi-Level Polities: The Nordic Countries Compared. Basingstoke: Palgrave Macmillan.

Baines, P., Scheucher, C. \& Plasser, F. (2001). The "Americanisation" myth in European political markets: A focus on the United Kingdom. European Journal of Marketing, 35(9-10), 10991117.

Bakker, R., De Vries, C., Edwards, E., Hooghe, L., Jolly, S., Marks, G. ... \& Vachudova, M. (2015). Measuring party positions in Europe: The Chapel Hill expert survey trend file, 1999-2010. Party Politics, 21(1), 143-152.

Banchoff, T. (1999). German identity and European integration. European Journal of International Relations, 5(3), 259-289.

Barbé, E. \& Herranz Surrallés, A. (2008). The power and practice of the European Parliament in security policies. In D. Peters, W. Wagner \& N. Deitelhoff (Eds.), The Parliamentary Control of European Security Policy, ARENA Report (7/08) (pp. 77-107). Oslo: ARENA Centre for European Studies. 
Barbière, C. (2018). European Parliament votes against transnational lists. EURACTIV. Retrieved March 24, 2020, from https://www.euractiv.com/section/elections/news/epvotes-against-transnational-lists/.

Bardi, L. (1994). Transnational party federations, European Parliament party groups and the building of Europarties. In R. Katz \& P. Mair (Eds.), How Parties Organize: Change and Adaptation in Party Organizations in Western Democracies (pp. 357-372). London: Sage Publications.

Bardi, L. (1996). Transnational trends in European parties and the 1994 elections of the European Parliament. Party Politics, 2(1), 99-114.

Bardi, L. (1997). Direct elections of the European Parliament and transnational trends in European parties. Paper presented at the European Community Studies Association, Washington. Retrieved from http://aei.pitt.edu/2531/1/002501_1.PDF

Bardi, L. \& Calossi, E. (2009). Models of party organization and Europarties. In J. DeBardeleben \& J. Pammett (Eds.), Activating the Citizen: Dilemmas of Participation in Europe and Canada (pp. 151-172). Basingstoke: Palgrave Macmillan.

Baum, J. \& Oliver, C. (1991). Institutional linkages and organizational mortality. Administrative Science Quarterly, 36(2), 187-218.

Bell, D. \& Lord, C. (Eds.). (1998). Transnational parties in the European Union. Aldershot: Ashgate.

Bellamy, R. \& Kröger, S. (2014). Domesticating the democratic deficit? The role of national parliaments and parties in the EU's system of governance. Parliamentary Affairs, 67(2), 437457.

Bengtson, C. (2007). Interparliamentary cooperation within Europe. In J. O'Brennan \& T. Raunio (Eds.), National Parliaments within the Enlarged European Union: From 'Victims' of Integration to Competitive Actors? (pp. 46-65). Abingdon: Routledge.

Bergman, T. (1997). National parliaments and EU affairs committees: Notes on empirical variation and competing explanations. Journal of European Public Policy, 4(3), 373-387.

Bergman, T. (2000). The European Union as the next step of delegation and accountability. European Journal of Political Research, 37(3), 415-429.

Benz, A. (2004). Path-dependent institutions and strategic veto players: National parliaments in the European Union. West European Politics, 27(5), 875-900.

Beyers, J. \& Kerremans, B. (2007). Critical resource dependencies and the Europeanization of domestic interest groups. Journal of European Public Policy, 14(3), 460-481.

Beyers, J., De Bruycker, I. \& Baller, I. (2015). The alignment of parties and interest groups in EU legislative politics: A tale of two different worlds? Journal of European Public Policy, 22(4), 534551.

Biermann, R. \& Harsch, M. (2017). Resource dependence theory. In R. Bierman \& J. Koops (Eds.), Palgrave Handbook of Inter-Organizational Relations in World Politics (pp. 135-155). Basingstoke: Palgrave Macmillan.

Blair, T. \& Schröder, G. (1999). Europe: The third way/die Neue Mitte. London: Labour Party.

Blom, T. \& Vanhoonacker, S. (2015). The European External Action Service (EEAS), the new kid on the block. In M. Bauer \& J. Trondal (Eds.), The Palgrave Handbook of the European Administrative System (pp. 208-223). Basingstoke: Palgrave Macmillan.

Blomgren, M. \& Rozenberg, O. (Eds.). (2015). Parliamentary Roles in Modern Legislatures. Abingdon: Routledge.

Böhmelt, T., Ezrow, L., Lehrer, R. \& Ward, H. (2016). Party policy diffusion. American Political Science Review, 110(2), 397-410.

Bomberg, E. (2002). The Europeanisation of green parties: Exploring the EU's impact. West European Politics, 25(3), 29-50.

Bono, G. (2006). Challenges of democratic oversight of EU security policies. European Security, 15(4), 431-449. 
Boomgaarden, H., De Vreese, C., Schuck, A., Azrout, R., Elenbaas, M., Van Spanje, J. \& Vliegenthart, R. (2013). Across time and space: Explaining variation in news coverage of the European Union. European Journal of Political Research, 52(5), 608-629.

Borońska-Hryniewiecka, K. (2015). The best of both worlds: The unexploited potential of interparliamentary cooperation in the EU. PISM Policy Paper, 27(129). Retrieved from https://www.pism.pl/files/?id_plik=20212.

Börzel, T. (2002). States and Regions in the European Union: Institutional Adaptation in Germany and Spain. Cambridge: Cambridge University Press.

Börzel, T. \& Heard-Lauréote, K. (2009). Networks in EU multi-level governance: Concepts and contributions. Journal of Public Policy, 29(2), 135-151.

Bouwen, P. (2002). Corporate lobbying in the European Union: The logic of access. Journal of European Public Policy, 9(3), 365-390.

Bowler, S. \& McElroy, G. (2015). Political group cohesion and 'hurrah' voting in the European Parliament. Journal of European Public Policy, 22(9), 1355-1365.

Braun, S. (2017). Neustart mit Gästen; Die Grünen haben sich für ihren Parteitag viel vorgenommen. Er soll sie aus dem Umfragetief holen. Dabei soll ihnen auch der Niederländer Jesse Klaver helfen. Der weiß, wie man einen Wahlerfolg zustande bringt. Süddeutsche Zeitung.

Braun, D. \& Popa, S.A. (2018). This time it was different? The salience of the Spitzenkandidaten system among European parties. West European Politics, 41(5), 1125-1145.

Braun, D. \& Schwarzbözl, T. (2019). Put in the spotlight or largely ignored? Emphasis on the Spitzenkandidaten by political parties in their online campaigns for European elections, Journal of European Public Policy, 26(3), 428-445.

Braunthal, G. (2003). The SPD, the welfare state, and Agenda 2010. German Politics and Society, 21(4), 1-29.

Bremer, B. (2017). The crisis of the SPD: Where now for Germany's social democrats? LSE European Politics and Policy (EUROPP) Blog. Retrieved from http:/ / eprints.lse.ac.uk/84815/1/europpblog-2017-09-28-the-crisis-of-the-spd-wherenow-for-germanys.pdf

Bressanelli, E. (2012). National parties and group membership in the European Parliament: Ideology or pragmatism? Journal of European Public Policy, 19(5), 737-754.

Bressanelli, E. (2013). Competitive and coherent? Profiling the Europarties in the 2009 European Parliament elections. Journal of European Integration, 35(6), 653-668.

Bressanelli, E. (2014). Europarties After enlargement: Organization, Ideology and Competition. Basingstoke: Palgrave MacMillan.

Brucker, M. (2007). Trans-national actors in democratizing states: The case of German political foundations in Ukraine. Journal of Communist Studies and Transition Politics, 23(2), 296-319.

Brunsson, N. (1986). Organizing for inconsistencies: On organizational conflict, depression and hypocrisy as substitutes for action. Scandinavian Journal of Management Studies, 2(3-4), 165-185.

Brzozowski, A., Rios, B. \& Fortuna, G. (2019). EPP votes to suspend Hungary's Fidesz party membership. EURACTIV. Retrieved July 17, 2019, from https://www.euractiv.com/section/future-eu/news/epp-votes-to-suspend-hungarysfidesz-party-membership/

Budden, P. (2002). Observations on the Single European Act and 'relaunch of Europe': A less 'intergovernmental' reading of the 1985 Intergovernmental Conference. Journal of European Public Policy, 9(1), 76-97.

Budge, I. (1994). A new spatial theory of party competition: Uncertainty, ideology and policy equilibria viewed comparatively and temporally. British Journal of Political Science, 24(4), 443467.

Budge, I. \& Laver, M. (1986). Office seeking and policy pursuit in coalition theory. Legislative Studies Quarterly, 11(4), 485-506. 
Bukow, S. (2016). The green party in Germany. In E. Van Haute (Ed.), Green Parties in Europe (pp. 126-153). Abingdon: Routledge.

Bulmer, S. (2008). Theorizing Europeanization. In P. Graziano \& M Vink (Eds.), Europeanization: New Research Agendas (pp. 46-58). Basingstoke: Palgrave Macmillan.

Bündnis 90/Die Grünen (2014). Europa mitentscheiden erneuern zusammenhalten: Europawahlprogramm 2014 von Bündnis 90/Die Grünen. Retrieved from https://cms.gruene.de/uploads/documents/Gruenes-Europawahlprogramm-2014.pdf

Bündnis 90/Die Grünen (2017, June 16). Jesse Klaver: Rede Bundesparteitag 2017 [video file]. Retrieved from https://www.youtube.com/watch?v=dHHensLTmzM

Bündnis 90/Die Grünen (2018). Europas Versprechen erneuern: Europawahlprogramm 2019. Retrieved from https://cms.gruene.de/uploads/documents/B90GRUENE_Europawahlprogramm_2019 barrierefrei.pdf

Burban, J.L. (1972). Relations entre le Parlement européen et les parlements nationaux. Revue du Marché Commun, 16(160), 780-790.

Burnell, P. \& Gerrits, A. (2010). Promoting party politics in emerging democracies. Democratization, 17(6), 1065-1084.

Calossi, E. \& Coticchia, F. (2013). The role of Europarties in framing the European Union foreign and security policy. RSCAS Working Papers, 3. Retrieved from http://cadmus.eui.eu/bitstream/handle/1814/25839/RSCAS_2013_03.pdf

Carothers, T. (2006). Examining international political party aid. In P. Burnell (Ed.), Globalising Democracy (pp. 81-99). London: Routledge.

Carter, E., Luther, K.R. \& Poguntke, T. (2007). European integration and internal party dynamics. In T. Poguntke, N. Aylott, E. Carter, R. Ladrech \& K.R. Luther (Eds.), The Europeanization of National Political Parties: Parties and Organizational Adaptation (pp. 1-27). London: Routledge.

Carter, E. \& Poguntke, T. (2010). How European integration changes national parties: Evidence from a 15-country study. West European Politics, 33(2), 297-324.

Casciaro, T. \& Piskorski, M.J. (2005). Power imbalance, mutual dependence, and constraint absorption: A closer look at resource dependence theory. Administrative Science Quarterly, 50(2), 167-199.

Chappell, L. (2016). Germany, Poland and the Common Security and Defence Policy: Converging Security and Defence Perspectives in an Enlarged EU. Basingstoke: Palgrave Macmillan.

Charmaz, K. (1995). Grounded theory. In J. Smith, R. Harré \& L. Langenhove (Eds.), Retbinking Methods in Psychology (pp. 27-49). London: Sage Publications.

Chiochetti, P. (2017). The Radical Left Party Family in Europe, 1989-2015. Abingdon: Routledge.

Christiansen, T. (2016). After the Spitzenkandidaten: Fundamental change in the EU's political system? West European Politics, 39(5), 992-1010.

Christiansen, T \& Groen, A. (2018). Inter-parliamentary cooperation in the European Union: Towards institutionalization? In K. Raube, M. Muftuler-Bac \& J. Wouters (Eds.), Parliamentary Cooperation and Diplomacy in EU External Relations (pp. 29-52). Cheltenham: Edward Elgar.

Christiansen, T. \& Neuhold, C. (2013). Informal politics in the EU. Journal of Common Market Studies, 51(6), 1196-1206.

Chryssogelos, A.S. (2015). Patterns of transnational partisan contestation of European foreign policy. European Foreign Affairs Review, 20(2), 227-245.

Chryssogelos, A.S. (2017). Transnational European party federations as EU foreign policy actors: The activities of Europarties in Eastern Partnership states. Journal of Common Market Studies, 55(2), 257-274. 
Claeys, P. \& Loeb-Mayer, N. (1979). Trans-European party groupings: Emergence of new and alignment of old parties in the light of the direct elections to the European Parliament. Government and Opposition, 14(4), 455-478.

Closa, C. \& Maatsch, A. (2014). In a spirit of solidarity? Justifying the European Financial Stability Facility (EFSF) in national parliamentary debates. Journal of Common Market Studies, 52(4), 826-842.

Collier, D. (2011). Understanding process tracing. Political Science \& Politics, 44(4), 823-830.

Cooper, I. (2015). A yellow card for the striker: National parliaments and the defeat of EU legislation on the right to strike, Journal of European Public Policy, 22(10), 1406-1425.

Cooper, I. (2016). The politicization of interparliamentary relations in the EU: Constructing and contesting the 'Article 13 Conference' on economic governance. Comparative European Politics, 14(2), 196-214.

Cooper, I. (2017). The emerging order of interparliamentary cooperation in the EU: Functional specialization, the EU Speakers Conference, and the parliamentary dimension of the Council presidency. EUI Working Paper RSCAS, 5. Retrieved from http://cadmus.eui.eu/bitstream/handle/1814/45151/RSCAS_2017_05.pdf

Corbett, R. (1998). The European Parliament's Role in Closer EU Integration. Basingstoke: Palgrave Macmillan.

COSAC (2014a). COSAC: Historical development. Retrieved January 8, 2017, from http://www.cosac.eu/documents/

COSAC (2014b). Twenty-first bi-annual report: Developments in European Union procedures and practices relevant to parliamentary scrutiny. Retrieved from http://www.cosac.eu/documents/bi-annual-reports-of-cosac/

Costa, E. (2018a). The Labour Party, Denis Healey and the International Socialist Movement: Rebuilding the Socialist International during the Cold War, 1945-1951. Cham: Palgrave Macmillan.

Costa, E. (2018b). The Socialist International and Italian social democracy (1948-50): Cultural differences and the 'internationalisation of domestic quarrels'. Historical Research, 91(251), 160-184.

Costa, O. \& Latek, M. (2001). Paradoxes and limits of interparliamentary cooperation in the European Union. Journal of European Integration, 23(2), 139-164.

Council of the European Union (2019). EUNAVFOR MED Operation Sophia: Mandate extended until 30 September 2019. Press release. Retrieved April 25, 2019, from https://www.consilium.europa.eu/en/press/press-releases/2019/03/29/eunavfor-medoperation-sophia-mandate-extended-until-30-september-2019/

Council Decision (CFSP)2015/778 on a European Union Military Operation in the Southern Central Mediterranean (EUNAVFOR MED). (2015). Official Journal of the European Union, L122, 31-35.

Council Decision (CFSP)2015/972 launching the European Union Military Operation in the Southern Central Mediterranean (EUNAVFOR MED). (2015). Official Journal of the European Union, L157, 51.

Council Decision (CFSP)2016/993 amending decision (CFSP)2015/778 on a European Military Operation in the Southern Central Mediterranean (EUNAVFOR MED operation Sophia). (2016). Official Journal of the European Union, L162, 18-20.

Council Decision (CFSP)2017/1385 of 25 July 2017 amending Decision (CFSP)2015/778 on a European Union Military Operation in the Southern Central Mediterranean (EUNAVFOR MED operation SOPHIA). (2017). Official Journal of the European Union, L194, 61-62.

Cravinho Report (1991). Report on the relations between the European Parliament and the national parliaments (DOC 116394.150.961/BUR/fin). Brussels: European Parliament.

Cross, M. (2013). Rethinking epistemic communities twenty years later. Review of International Studies, 39(1), 137-160. 
Crum, B. \& Fossum, J.E. (2009). The multilevel parliamentary field: A framework for theorizing representative democracy in the EU. European Political Science Review, 1(2), 249-271.

Crum, B. \& Fossum, J.E. (Eds.). (2013a). Practices of Inter-Parliamentary Coordination in International Politics: The European Union and Beyond. Colchester: ECPR Press.

Crum, B. \& Fossum, J.E. (2013b). Conclusion: Towards a democratic multi-level playing field? In B. Crum \& J.E. Fossum (Eds.), Practices of Inter-Parliamentary Coordination in International Politics: The European Union and Beyond (pp. 251-267). Colchester: ECPR Press.

Cuperus, R. (1999). Het Duitse debat: Over Schröder, Lafontaine en 'das Papier'. Socialisme en Democratie, 56(11), 509-513.

Cusumano, E. (2019). Migrant rescue as organized hypocrisy: EU maritime missions offshore Libya between humanitarianism and border control. Cooperation and Conflict, 54(1), 3-24.

Dakowska, D. (2002). Beyond conditionality: EU enlargement, European party federations and the transnational activity of German political foundations. Perspectives on European Politics and Society, 3(2), 271-296.

Dakowska, D. (2005). German political foundations: Transnational party go-betweens in the EU enlargement process. In W. Kaiser \& P. Starie (Eds.), Transnational European Union: Towards a Common Political Space (pp. 166-185). London: Routledge.

Dakowska, D. (2009). Networks of foundations as norm entrepreneurs: Between politics and policies in EU decision-making. Journal of Public Policy, 29(2), 201-221.

Dalton, R. \& Wattenberg, M. (2002). Parties without Partisans: Political Change in Advanced Industrial Democracies. Oxford: Oxford University Press.

Damgaard, E. \& Jensen, H. (2005). Europeanisation of executive-legislative relations: Nordic perspectives. The Journal of Legislative Studies, 11(3-4), 394-411.

Davis, G. \& Cobb, J.A. (2010). Resource dependence theory: Past and future. In C.B. Schoonhoven \& F. Dobbin (Eds.), Stanford's Organization Theory Renaissance, 1970-2000 (pp. 21-42). Bingley: Emerald Group Publishing.

Davis, R. \& Stazyk, E. (2015). Examining the links between senior managers' engagement in networked environments and goal and role ambiguity. Journal of Public Administration Research and Theory, 26(3), 433-447.

Day, S. (2005). Developing a conceptual understanding of Europe's transnational political parties (with a specific focus on the Party of European Socialists). Journal of Contemporary European Studies, 13(1), 59-77.

Day, S. (2014). Between 'containment' and 'transnationalization': Where next for the Europarties? Acta Politica, 49(1), 5-29.

De Cleen, B., Moffitt, B., Panayotu, P. \& Stavrakakis, Y. (2019). The potentials and difficulties of transnational populism: The case of the Democracy in Europe Movement 2025 (DiEM25). Political Studies. https://doi.org/10.1177/0032321719847576

De Vries, C. (2007). Sleeping giant: Fact or fairytale? How European integration affects national elections. European Union Politics, 8(3), 363-385.

De Vries, C. \& Edwards, E. (2009). Taking Europe to its extremes: Extremist parties and public Euroscepticism. Party Politics, 15(1), 5-28.

De Wilde, P. (2011). Ex ante vs. ex post: The trade-off between partisan conflict and visibility in debating EU policy-formulation in national parliaments. Journal of European Public Policy, 18(5), 672-689.

De Wilde, P. \& Zürn, M. (2012). Can the politicization of European integration be reversed? Journal of Common Market Studies, 50(1), 137-153.

Decker, F. (2014). Follow-up to the Grand Coalition: The German party system before and after the 2013 federal election. German Politics and Society, 32(2), 19-40.

Declaration of the Third Mediterranean Conference of the Left (2017). Retrieved from https://portside.org/2017-04-26/declaration-third-mediterranean-conference-left 
Deephouse, D. (1996). Does isomorphism legitimate? Academy of Management Journal, 39(4), 10241039.

Delwit, P., Külahci, E. \& Van De Walle, C. (2004). The Europarties: Organisation and Influence. Brussels: Editions de l'Université de Bruxelles.

Deschouwer, K. (2000). The European multi-level party systems: Towards a framework of analysis, EUI W orking Papers (RSC), 47.

Deutscher Bundestag (n.d.). The defence committee: Tasks and procedures. Retrieved January 25, 2018, from https://www.bundestag.de/ausschuesse/a12_Verteidigung/arbeit-undaufgaben-des-verteidigungsausschusses-englisch/542648

Deutscher Bundestag (n.d.). The liaison office of the German Bundestag in Brussels. https://www.btg-bestellservice.de/pdf/81023000.pdf

Deutscher Bundestag (2015a). Beteiligung bewaffneter deutscher Streitkräfte an der EUOperation EUNAVFOR MED als ein Teil der Gesamtinitiative der EU zur Unterbindung des Geschäftsmodells der Menschenschmuggel- und Menschenhandelsnetzwerke im südlichen und zentralen Mittelmeer (18/6013). Antrag der Bundesregierung. Retrieved from http://dip21.bundestag.de/dip21/btd/18/060/1806013.pdf

Deutscher Bundestag (2015b). Antwort der Bundesregierung auf die Kleine Anfrage der Abgeordneten Ulla Jelpke, Herbert Behrens, Jan Korte, weiterer Abgeordneter und der Fraktion DIE LINKE (18/5572). Retrieved from http://dip21.bundestag.de/dip21/btd/18/055/1805572.pdf

Deutscher Bundestag (2015c). Stenografischer Bericht 124. Sitzung: Berlin, Donnerstag, den 24. September 2015. (Plenarprotokoll 18/124). Retrieved from http://dipbt.bundestag.de/dip21/btp/18/18124.pdf

Deutscher Bundestag (2015d). Stenografischer Bericht 127. Sitzung: Berlin, Donnerstag, den 1. Oktober 2015. (Plenarprotokoll 18/127). Retrieved from http://dipbt.bundestag.de/doc/btp/18/18127.pdlesf

Deutscher Bundestag. (2016a). Fortsetzung und Erweiterung der Beteiligung bewaffneter deutscher Streitkräfte an EUNAVFOR MED Operation SOPHIA (18/8878). Antrag der Bundesregierung. Retrieved from http://dip21.bundestag.de/dip21/btd/18/088/1808878.pdf

Deutscher Bundestag. (2016b). Stenografischer Bericht 183. Sitzung: Berlin, Donnerstag, den 7. Juli 2016. (Plenarprotokoll 18/183). Retrieved from http://dipbt.bundestag.de/doc/btp/18/18183.pdf

Deutscher Bundestag. (2016c). Stenografischer Bericht 180. Sitzung: Berlin, Donnerstag, den 24. Juni 2016. (Plenarprotokoll 18/180). Retrieved from http://dipbt.bundestag.de/doc/btp/18/18180.pdf

Deutscher Bundestag (2017a). Fortsetzung der Beteiligung bewaffneter deutscher Streitkräfte an EUNAVFOR MED Operation SOPHIA (18/12491). Antrag der Bundesregierung. Retrieved from http://dipbt.bundestag.de/dip21/btd/18/124/1812491.pdf

Deutscher Bundestag (2017b). Stenografischer Bericht 243. Sitzung: Berlin, Donnerstag, den 29. Juni 2017. (Plenarprotokoll 18/243). Retrieved from http://dipbt.bundestag.de/dip21/btp/18/18243.pdf

Deutscher Bundestag (2018a). Fortsetzung der Beteiligung bewaffneter deutscher Streitkräfte an EUNAVFOR MED Operation SOPHIA (19/2381). Antrag der Bundesregierung. Retrieved from http://dipbt.bundestag.de/dip21/btd/19/023/1902381.pdf

Deutscher Bundestag (2018b). Operation EUNAVFOR Med Sophia: Hintergrundinformationen (WD 2 - 23000 - $379 / 18$ ). Retrieved from https://www.bundestag.de/resource/blob/564232/90f5762db0821ec9a0b963253fc03912 /wd-2-079-18-pdf-data.pdf 
Deutscher Bundestag (2018c). Stenografischer Bericht 39. Sitzung: Berlin, Donnerstag, den 14. Juni 2018. (Plenarprotokoll 19/39). Retrieved from http://dipbt.bundestag.de/dip21/btp/19/19039.pdf

Deutscher Bundestag (2018d). Stenografischer Bericht 36. Sitzung: Berlin, Donnerstag, den 7. June 2018. (Plenarprotokoll 19/36). Retrieved from http://dipbt.bundestag.de/dip21/btp/19/19036.pdf

Deutscher Bundestag (2019). Datenhandbuchs zur Geschichte des Deutschen Bundestages. Berlin: Deutscher Bundestag. Retrieved from https://www.bundestag.de/datenhandbuch

Die Linke (n.d.). Wahlkampfmaterialien befreundeter Parteien im Europawahlkampf 2014. Retrieved from https://archiv2017.die-linke.de/die-linke/wahlen/archiv/europawahlen2014/kampagne/wahlkampfmaterialien-befreundeter-parteien/

Die Linke (2012). Auf euren Erfolg hofft ganz Europa: Rede von Francisco Louçã, Vorsitzender des Linksblocks Portugal, auf dem Göttinger Parteitag. Retrieved from https://archiv2017. die-linke.de/index.php?id $=10075$

Die Linke (2013a). 100\% sozial: Wahlprogramm zur Bundestagswahl 2013. Retrieved from https://archiv2017.die-

linke.de/fileadmin/download/wahlen2013/bundestagswahlprogramm/bundestagswahlpro gramm2013_langfassung.pdf

Die Linke (2013b). Sind wir stark genug? Noch nicht! Rede von Marisa Matias, MdEP, Linksblock (Portugal), Stellvertretende Vorsitzende der Partei der Europäischen Linken. Retrieved from https://archiv2017.die-linke.de/partei/organe/parteitage/archiv/dresdnerparteitag-2013/reden/marisa-matias-mdep-linksblock-stellvertretende-vorsitzende-derpartei-der-europaeischen-linken/

Die Linke (2014a). Europa geht anders: Sozial, friedlich, demokratisch. Retireved from https://www.die-

linke.de/fileadmin/download/wahlprogramme_alt/europawahlprogramm2014.pdf

Die Linke (2014b). Dieser Mai ist unser: Rede von Alexis Tsipras, Vorsitzender von SYRIZA (Griechenland) und Spitzenkandidat der Europäischen Linkspartei für die Europawahl. Retrieved from https://archiv2017.die-linke.de/partei/organe/parteitage/archiv/berlinerparteitag-2014/reden/alexis-tsipras/

Die Linke (2014c). Strategie der Partei DIE LINKE für die Wahl zum Europäischen Parlament 2014: Beschluss des Parteivorstandes. Retrieved from https://archiv2017.die-linke.de/dielinke/wahlen/archiv/europawahlen-2014/wahlstrategie/

Die Linke (2017). Die Zukunft für die wir kämpfen! Langfassung des Wahlprogramms zur Bundestagswahl 2017. Retrieved from https://www.dielinke.de/fileadmin/download/wahlen2017/wahlprogramm2017/die_linke_wahlprogramm 2017.pdf

Die Linke (2018). Wahlstrategie für die Europawahl 2019: Beschluss des Parteivorstandes. Retrieved from https://www.die-linke.de/partei/parteistruktur/parteivorstand/20162018/beschluesse/detail/news/wahlstrategie-fuer-die-europawahl-2019/

Die Linke (2019). Europa nur solidarisch: Europawahl 2019 Wahlprogramm. Retrieved from https://www.die-

linke.de/fileadmin/download/wahlen2019/wahlprogramm_pdf/Europawahlprogramm_2 019_-_Partei_DIE_LINKE_Druckversion_.pdf

Dieterich, S., Hummel, H. \& Marschall, S. (2010). Parliamentary war powers: A survey of 25 European parliaments. Geneva Centre for Democratic Control of Armed Forces, Occasional Paper, 21.

Dietz, T. (1997). Die Grenzuberschreitende Interaktion Gruner Parteien in Europa. Opladen: Westdeutscher Verlag.

Dietz, T. (2000). Similar but different? The European Greens compared to other transnational party federations in Europe. Party Politics, 6(2), 199-210. 
Dimitrakopoulos, D. (2001). Incrementalism and path dependence: European integration and institutional change in national parliaments. Journal of Common Market Studies, 39(3), 405-422.

Dolowitz, D., Greenwold, S. \& Marsh, D. (1999). Policy transfer: Something old, something new, something borrowed, but why red, white and blue? Parliamentary Affairs, 52(4), 719-730.

Döring, H. \& Manow, P. (2019). Parliaments and governments database (ParlGov): Information on parties, elections and cabinets in modern democracies. Development version. Retrieved from http://www.parlgov.org

Dostal, J. (2017). The German federal election of 2017: How the wedge issue of refugees and migration took the shine off Chancellor Merkel and transformed the party system. The Political Quarterly, 88(4), 589-602.

Dowling, J. \& Pfeffer, J. (1975). Organizational legitimacy: Social values and organizational behavior. Pacific Sociological Review, 18(1), 122-136.

Downs, A. (1957). An Economic Theory of Democracy. New York: Harper and Row.

Drees, J. \& Heugens, P. (2013). Synthesizing and extending resource dependence theory: A metaanalysis. Journal of Management, 39(6), 1666-1698.

Drögemöller, M. (2005). Zwei Schwestern in Europa: Die Deutsche und Niederländische Sozialdemokratie zur Zeit der Teilung Deutschlands 1945-1990 (Doctoral dissertation). Münster: Westfälischen Wilhelms-Universität.

Dunphy, R. \& March, L. (2013). Seven year itch? The European Left party: Struggling to transform the EU. Perspectives on European Politics and Society, 14(4), 520-537.

Duverger, M. (1954). Political Parties: Their Organization and Activities in the Modern State. London: Methuen.

Eldersveld, S. (1964). Political Parties. Chicago: Rand McNally.

Emerson, R.M. (1962). Power-dependence relations. American sociological review, 27(1), 31-41.

Erdmann, G. (2006). Hesitant bedfellows: The German Stiftungen and party aid in Africa. In P. Burnell (Ed.), Globalising Democracy (pp. 193-211). London: Routledge.

European Commission (2020). Shaping the Conference on the Future of Europe. Press release. Retrieved from https://ec.europa.eu/commission/presscorner/detail/en/ip_20_89.

European Communities (2001). Gaetano Martino: Ten Years in the European Parliament (1957-1967). A Scientist at the Service of Europe - Parliamentary Speeches Given During Various Periods of Office. Retrieved http://www.europarl.europa.eu/RegData/etudes/etudes/join/2001/305002/DG-4AFCO_ET(2001)305002_EN.pdf

EU Speakers Conference (1963). Final Communique after the Speakers Conference on 11 January 1963. Retrieved from http://www.ipex.eu/IPEXLWEB/dossier/files/download/082dbcc538a48f380139911bc1025df6.do

EU Speakers Conference (1975). Final Communiqué after the Speakers Conference on 26-27 September 1975. Retrieved from http://www.ipex.eu/IPEXLWEB/dossier/files/download/082dbcc538a48f380139441b84813f8f.do

EPP Group (n.d.). How we make it happen: With national parliaments. Retrieved June 29, 2019, https://www.eppgroup.eu/how-we-make-it-happen/with-national-parliaments

European Council. (2015). Special meeting of the European Council, 23 April 2015 - Statement. Retrieved from https://www.consilium.europa.eu/en/press/pressreleases/2015/04/23/special-euco-statement/

European External Action Service (n.d.). About EUNAVFOR MED operation SOPHIA. Retrieved September 18, 2017, from https://eeas.europa.eu/csdp-missionsoperations/eunavfor-med/36/about-eunavfor-med-operation-sophia_en

European Green Party (2015). Resolution "The EU and Europeans can do more for refugees". Lyon, 23rd Council. Retrieved from https://europeangreens.eu/sites/europeangreens.eu/files/news/files/4.EU\%20and $\% 20 \mathrm{E}$ 
uropeans $\% 20$ can $\% 20 \mathrm{do} \% 20$ more $\% 20$ for $\% 20$ Refugees $\% 20$ resolution $\% 20$ as $\% 20$ adopted.p df

European Green Party (2018a). EGP priorities for 2019: What European greens fight for. Berlin, 29th Council. Retrieved from https:// europeangreens.eu/sites/europeangreens.eu/files/Adopted $\% 20 \mathrm{EGP} \% 20$ priorities $\% 20$ for $\% 202019$ EN.pdf

European Green Party (2018b). Adopted EGP manifesto 2019. Berlin, 29th Council. Retrieved from

https://europeangreens.eu/sites/ europeangreens.eu/files/8.\%20PROOFREAD\%20Adop ted $\% 20 \% 20$ EGP $\% 20$ Manifesto $\% 202019$.pdf

European Green Party (2018c). Campaign plan. Berlin, 29th Council. Retrieved from https:// europeangreens.eu/sites/europeangreens.eu/files/7.1\%20Adopted $\% 20$ -

$\% 20$ Campaign $\% 20 \mathrm{Plan} \% 20-\% 20$ EGP.pdf

European Green Party (2018d). Amendments to the draft manifesto 2019. Berlin, 29th Council. Retrieved from https://europeangreens.eu/sites/europeangreens.eu/files/008.\%20FULL\%20SET\%20$\% 20$ Amendments_to_draft_manifesto $\% 200 T \% 20 \mathrm{av} \% 20 \mathrm{OT} \% 20 \mathrm{av}$.pdf

European Parliament (n.d.). Funding from the European Parliament to political parties at European level per party and per year, http://www.europarl.europa.eu/pdf/grants/funding_amounts_parties_01-2019.pdf

European Parliament (2015a). Motion for a resolution to wind up the debate on the statements by the Council and the Commission pursuant to Rule 123(2) of the Rules of Procedure on migration and the situation of refugees (B8-0835/2015). Retrieved from https://www.europarl.europa.eu/doceo/document/B-8-2015-0835_EN.pdf

European Parliament (2015b). Motion for a resolution to wind up the debate on the statements by the Council and the Commission pursuant to Rule 123(2) of the Rules of Procedure on migration and refugees in Europe (B8-0837/2015). Retrieved from https://www.europarl.europa.eu/doceo/document/B-8-2015-0837_EN.pdf

European Parliament (2019). Constitution of the 9th legislature of the European Parliament. Press Release. Retrieved from https://www.europarl.europa.eu/news/en/pressroom/20190627IPR55404/constitution-of-the-9th-legislature-of-the-european-parliament

Faas, T. (2003). To defect or not to defect? National, institutional and party group pressures on MEPs and their consequences for party group cohesion in the European Parliament. European Journal of Political Research, 42(6), 841-866.

Faas, T. (2015). The German federal election of 2013: Merkel's triumph, the disappearance of the Liberal Party, and yet another grand coalition. West European Politics, 38(1), 238-247.

Faleg, G. \& Blockmans, S. (2015). EU naval force EUNAVFOR MED sets sail in troubled waters, CEPS Commentary. Retrieved from https://www.ceps.eu/wpcontent/uploads/2015/06/CEPS $\% 20$ Commentary $\% 20$ EUNAVFOR $\% 20$ G $\% 20 \mathrm{Faleg}^{0} \% 20$ S\%20Blockmans_0.pdf

Farrell, D. \& Webb, P. (2002). Political parties as campaign organizations. In R. Dalton \& M. Wattenberg (Eds.), Parties without Partisans: Political Change in Advanced Industrial Democracies (pp. 108-128). Oxford: Oxford University Press.

Fasone, C. (2012). Interparliamentary cooperation and democratic representation in the European Union. In S. Kröger \& D. Friedrich (Eds.), The Challenge of Democratic Representation in the European Union (pp. 41-58). Basingstoke: Palgrave Macmillan.

Ferrara, F. \& Weishaupt, J. (2004). Get your act together: Party performance in European Parliament elections. European Union Politics, 5(3), 283-306.

Finke, D. \& Herbel, A. (2015). Beyond rules and resources: Parliamentary scrutiny of EU policy proposals. European Union Politics, 16(4), 490-513. 
Fiott, D. (2015). Being small, acting tall? Malta and European defence. In D. Fiott (Ed.), The Common and Security Policy: National Perspectives, Egmont Paper 69. Brussels: Egmont - The Royal Institute for International Relations.

Flick, U. (2004). Triangulation in qualitative research. In U. Flick, E. von Kardoff \& I. Steinke (Eds.), A Companion to Qualitative Research (pp. 178-183). London: Sage Publications.

Flinders, M. \& Kelso, A. (2011). Mind the gap: Political analysis, public expectations and the parliamentary decline thesis. The British Journal of Politics and International Relations, 13(2), 249268.

Follesdal, A. \& Hix, S. (2006). Why there is a democratic deficit in the EU: A response to Majone and Moravcsik. Journal of Common Market Studies, 44(3), 533-562.

Fonck, D. (2018). Parliamentary diplomacy and legislative-executive relations in EU foreign policy: Studying the European Parliament's mediation of the Macedonian political crisis (2015-17). Journal of Common Market Studies, 56(6), 1305-1322.

Fonck, D., Haesebrouck, T. \& Reykers, Y. (2019). Parliamentary involvement, party ideology and majority-opposition bargaining: Belgian participation in multinational military operations. Contemporary Security Policy, 40(1), 85-100.

Franzmann, S., Giebler, H. \& Poguntke, T. (2019). It's no longer the economy, stupid! Issue yield at the 2017 German federal election. West European Politics, 1-29. https://doi.org/10.1080/01402382.2019.1655963

Fromage, D. (2016). Increasing inter-parliamentary cooperation in the European Union: Current trends and challenges. European Public Law, 22(4), 749-772.

Gaffney, J. (Ed.) (1996). Political Parties and the European Union. London: Routledge.

Gagatek, W. (2009). European Political Parties as Campaign Organisations: Towards a Greater Politicization of the European Parliament Elections. Brussels: Wilfried Martens Centre for European Studies.

Gagatek, W. \& Van Hecke, S. (2014). The development of European political foundations and their role in strengthening Europarties. Acta Politica, 49(1), 86-104.

Galaskiewicz, J. (1985). Interorganizational relations. Annual Review of Sociology, 11(1), 281-304.

Gattermann, K. (2014). Opportunities, strategies and ideologies: The incentives of European Parliament political groups for inter-parliamentary cooperation. OPAL Online Paper Series, 16.

Gattermann, K., De Vreese, C. \& Van Der Brug, W. (2016). Evaluations of the Spitzenkandidaten: The role of information and news exposure in citizens' preference formation. Politics and Governance, 4(1), 37-54.

Gattermann, K. \& Hefftler, C. (2015b). Beyond institutional capacity: Political motivation and parliamentary behaviour in the Early Warning System. West European Politics, 38(2), 305-334.

Gattermann, K., Högenauer, A.L. \& Huff, A. (2016). Research note: Studying a new phase of Europeanisation of national parliaments. European Political Science, 15(1), 89-107.

Gehler, M. (2010). On the long and winding road to European Union membership: Austrian party elites in transnational political networks. In W. Kaiser, B. Leucht \& M. Gehler (Eds.), Transnational Networks in Regional Integration: Governing Europe 1945-1983 (pp. 199-220). London: Palgrave Macmillan.

George, A. \& Bennett, A. (2004). Case Studies and Theory Development in the Social Sciences. Cambridge, Massachusetts: MIT Press.

Gerring, J. (2004). What is a case study and what is it good for? American Political Science Review, 98(2), 341-354.

Gerring, J. (2006). Case Study Research: Principles and Practices. Cambridge: Cambridge University Press.

Gerring, J. (2007). The case study: What it is and what it does. In C. Boix \& S. Stokes (Eds.), The Oxford Handbook of Comparative Politics (pp. 90-122). Oxford: Oxford University Press.

Gibson, R. \& Römmele, A. (2001). Changing campaign communications: A party-centered theory of professionalized campaigning. Harvard International Journal of Press/Politics, 6(4), 31-43. 
Gilpin, R. (1971). The politics of transnational economic relations. International Organization, 25(3), 398-419.

Goetz, K. \& Meyer-Sahling, J.H. (2008). The Europeanisation of national political systems: Parliaments and executives, Living Reviews in European Governance, 3(2). Retrieved from http://www.livingreviews.org/lreg-2008-2

Goldstein, K. (2002). Getting in the door: Sampling and completing elite interviews. Political Science \& Politics, 35(4), 669-672.

Gómez-Reino, M. (2018). Nationalisms in the European Arena: Trajectories of Transnational Party Coordination. Basingstoke: Palgrave Macmillan.

Gondo, M., Amis, J. \& Vardaman, J. (2010). Case within a case. In A. Mills, G. Durepos \& E. Wiebe (Eds.), Encyclopedia of Case Study Research (pp. 135-137). Thousand Oaks: Sage Publications.

Granat, K. (2018). The Principle of Subsidiarity and Its Enforcement in the EU Legal Order: The Role of National Parliaments in the Early Warning System. Oxford: Hart Publishing.

Granovetter, M.S. (1977). The strength of weak ties. American Journal of Sociology, 78(6), 1360-1380.

Green-Pedersen, C. (2012). A giant fast asleep? Party incentives and the politicisation of European integration. Political Studies, 60(1), 115-130.

Groen, A. \& Christiansen, T. (2015). National parliaments and the European Union: Conceptual choices in the European Union's constitutional debate. In C. Heffter, C. Neuhold, O. Rozenberg \& J. Smith (Eds.), The Palgrave Handbook of National Parliaments and the European Union (pp. 43-59). Basingstoke: Palgrave Macmillan.

Grosek, K. (2018). European political parties and political foundations: Statute and funding. Briefing: EU legislation in progress. European Parliamentary Research Service, PE 620.198. Retrieved

from http://www.europarl.europa.eu/RegData/etudes/BRIE/2018/620198/EPRS_BRI(2018)6 20198_EN.pdf

Guidelines for Inter-parliamentary Cooperation in the European Union (2008). Retrieved from https://secure.ipex.eu/IPEXL-WEB/about/guidelines.do

Guyomarch, A. (1995). The European dynamics of evolving party competition in France. Parliamentary Affairs, 48(1), 100-125.

Haas, E. (1958). The Uniting of Europe: Political, Social and Economic Forces, 1950-57. London: Stevens and Sons.

Haas, P. (1992). Introduction: Epistemic communities and international policy coordination. International Organization, 46(1), 1-35.

Hanley, D. (2008). Beyond the Nation State: Parties in the Era of European Integration. Basingstoke: Palgrave Macmillan.

Hansen, M. \& Olsen, J. (2019). Flesh of the same flesh: A study of voters for the Alternative for Germany (AfD) in the 2017 Federal Election. German Politics, 28(1), 1-19.

Harmel, R. \& Janda, K. (1994). An integrated theory of party goals and party change. Journal of Theoretical Politics, 6(3), 259-287.

Harvey, W. (2011). Strategies for conducting elite interviews. Qualitative Research, 11(4), 431-441.

Haughton, T. (2009). Driver, conductor or fellow passenger? EU membership and party politics in Central and Eastern Europe. Journal of Communist Studies and Transition Politics, 25(4), 413 426.

Haverland, M. (2006). Does the EU cause domestic developments? Improving case selection in Europeanisation research. West European Politics, 29(1), 134-146.

Heaney, M. (2010). Linking political parties and interest groups. In L. Maisel \& J. Berry (Eds.), The Oxford Handbook of American Political Parties and Interest Groups (pp. 568-587). Oxford: Oxford University Press. 
Hecht, P. (2018). Über Grenzen hinweg; Varoufakis Bewegung DiEM25 will bei den Europawahlen antreten und könnte Linken und Grünen Konkurrenz machen. Am Samstag steht die Gründung des deutschen Flügels an. taæ, die tageszeitung.

Hefftler, C. (2015). An ever closer inter-parliamentary network? National parliaments' priorities in inter-parliamentary cooperation in the EU. Paper presented at EUSA Conference, Boston. Retrieved from http://aei.pitt.edu/79038/1/Hefftler.pdf

Hefftler, C. (2018). Opposition Parties and EU Affairs in National Parliaments: Cooperation or Competition? (Doctoral dissertation). Retrieved from https://kups.ub.unikoeln.de/8595/1/Dissertation \%20Hefftler\%202018.pdf

Hefftler, C. \& Gattermann, K. (2015). Interparliamentary cooperation in the European Union: Patterns, problems and potential. In C. Heffter, C. Neuhold, O. Rozenberg \& J. Smith (Eds.), The Palgrave Handbook of National Parliaments and the European Union (pp. 94-115). Basingstoke: Palgrave Macmillan.

Hefftler, C., Neuhold, C., Rozenberg, O. \& Smith, J. (Eds.). (2015). The Palgrave Handbook of National Parliaments and the European Union. Basingstoke: Palgrave Macmillan.

Hegeland, H. \& Neuhold, C. (2002). Parliamentary participation in EU affairs in Austria, Finland and Sweden: Newcomers with different approaches. European Integration online Papers, 6(10).

Heidar, K. \& Saglie, J. (2003). Predestined parties? Organizational change in Norwegian political parties. Party Politics, 9(2), 219-239.

Heinisch, R. (2003). Success in opposition-failure in government: Explaining the performance of right-wing populist parties in public office. West European Politics, 26(3), 91-130.

Hepburn, E. (Ed.) (2010). Using Europe: Territorial Party Strategies in a Multi-Level System. Manchester: Manchester University Press.

Herbel, A. (2017). Parliamentary scrutiny of the EU's Common Foreign and Security Policy. West European Politics, 40(1), 161-182.

Héritier, A. (2003). Composite democracy in Europe: The role of transparency and access to information. Journal of European Public Policy, 10(5), 814-833.

Herman, V. \& Van Schendelen, R. (Eds.) (1979). The European Parliament and the National Parliaments. Westmead: Saxxon House.

Herranz-Surrallés, A. (2014). The EU's multilevel parliamentary (battle) field: Inter-parliamentary cooperation and conflict in foreign and security policy. West European Politics, 37(5), 957975.

Herranz-Surrallés, A. (2019). Paradoxes of parliamentarization in European security and defence: When politicization and integration undercut parliamentary capital. Journal of European Integration, 41(1), 29-45.

Hertner, I. (2011a). Don't mention Europe: A study of the Europeanisation of Party Organisation in the British Labour Party, the French Socialist Party and the German Social Democratic Party (Doctoral dissertation). Department of Politics and International Relations: University of London.

Hertner, I. (2011b). Are European election campaigns Europeanized? The case of the Party of European Socialists in 2009. Government and Opposition, 46(3), 321-344.

Hillman, A., Shropshire, C. \& Cannella, A. (2007). Organizational predictors of women on corporate boards. Academy of Management Journal, 50(4), 941-952.

Hillman, A., Withers M. \& Collins, B. (2009). Resource Dependence Theory: A review. Journal of Management, 35(6), 1404-1427.

Hix, S. (1996). The transnational party federations. In J. Gaffney (Ed.), Political Parties and the European Union (pp. 308-331). London: Routledge.

Hix, S. \& Hagemann, S. (2009). Could changing the electoral rules fix European Parliament elections? Politique européenne, 2(28), 37-52.

Hix, S. \& Lesse, U. (2002). Shaping a Vision: A History of the Party of European Socialists. Brussels: Party of European Socialists.

Hix, S. \& Lord, C. (1997). Political Parties in the European Union. London: Palgrave Macmillan. 
Hix, S. \& Marsh, M. (2011). Second-order effects plus pan-European political swings: An analysis of European Parliament elections across time. Electoral Studies, 30(1), 4-15.

Hix, S. \& Marsh, M. (2007). Punishment or protest? Understanding European parliament elections. The Journal of Politics, 69(2), 495-510.

Hix, S. \& Noury, A. (2009). After enlargement: Voting patterns in the sixth European Parliament. Legislative Studies Quarterly, 34(2), 159-174.

Hix, S., Kreppel, A. \& Noury, A. (2003). The party system in the European Parliament: Collusive or competitive? Journal of Common Market Studies, 41(2), 309-331.

Hix, S., Noury, A. \& Roland, G. (2007). Democratic Politics in the European Parliament. Cambridge: Cambridge University Press.

Hobolt, S. (2014). A vote for the President? The role of Spitzenkandidaten in the 2014 European Parliament elections. Journal of European Public Policy, 21(10), 1528-1540.

Hobolt, S. \& Karp, J. (2010). Voters and coalition governments. Electoral Studies, 29(3), 299-307.

Hobolt, S. \& Spoon, J. (2012). Motivating the European voter: Parties, issues and campaigns in European Parliament elections. European Journal of Political Research, 51(6), 701-727.

Högenauer, A.L. \& Neuhold, C. (2015). National parliaments after Lisbon: Administrations on the rise? West European Politics, 38(2), 335-354.

Högenauer, A.L., Neuhold, C. \& Christiansen, T. (2016). Parliamentary Administrations in the European Union. Basingstoke: Palgrave Macmillan.

Hofmann, S. (2013). European Security in NATO's Shadow: Party Ideologies and Institution Building. Cambridge: Cambridge University Press.

Höing, O. (2015). With a little help of the constitutional court: The Bundestag on its way to an active policy-shaper. In C. Hefftler, C. Neuhold, O. Rozenberg \& J. Smith (Eds.), The Palgrave Handbook of National Parliaments and the European Union (pp. 191-208). Basingstoke: Palgrave Macmillan.

Holmes, M. \& Lightfoot, S. (2011). Limited influence? The role of the Party of European Socialists in shaping social democracy in Central and Eastern Europe. Government and Opposition, 46(1), 32-55.

Holtz-Bacha, C. (2019). The European election in Germany: The Greta effect? In N. Bolin, K. Falasca, M. Grusell \& L. Nord (Eds.), Euroreflections: Leading Academics on the European Elections 2019 (p. 37). Sundsvall: Mittuniversitetet, Demicom.

Holtz-Bacha, C. (2002). Professionalization of political communication, Journal of Political Marketing, 1(4), 23-37.

Holzhacker, R. (2002). National parliamentary scrutiny over EU issues: Comparing the goals and methods of governing and opposition parties. European Union Politics, 3(4), 459-479.

Holzhacker, R. (2005). The power of opposition parliamentary party groups in European scrutiny. The Journal of Legislative Studies, 11(3-4), 428-445.

Hooghe, L. \& Marks, G. (2018). Cleavage theory meets Europe's crises: Lipset, Rokkan, and the transnational cleavage. Journal of European Public Policy, 25(1), 109-135.

Hooghe, L., Marks, G. \& Wilson, C. (2002). Does left/right structure party positions on European integration? Comparative political studies, 35(8), 965-989.

Hough, D. \& Keith, D. (2019). The German left party: A case of pragmatic populism. In G. Katsambekis \& A. Kioupkiolis (Eds.), The Populist Radical Left in Europe (pp. 129-144). Abingdon: Routledge.

Hough, D., Koss, M. \& Olsen, J. (2007). The Left Party in Contemporary German Politics. Basingstoke: Palgrave Macmillan.

Houghton, D.P. (2007). Reinvigorating the study of foreign policy decision making: Toward a constructivist approach. Foreign Policy Analysis, 3(1), 24-45.

House of Lords. (2017). Operation Sophia: A failed mission (HL Paper 5). Retrieved from https://publications.parliament.uk/pa/ld201719/ldselect/ldeucom/5/5.pdf 
Hudson, V. (2005). Foreign policy analysis: Actor-specific theory and the ground of international relations. Foreign Policy Analysis, 1(1), 1-30.

Huff, A. (2015). Executive privilege reaffirmed? Parliamentary scrutiny of the CFSP and CSDP. West European Politics, 38(2), 396-415.

Hult, K. (2003) Environmental perspectives on public institutions. In B.G. Peters \& J. Pierre (Eds.), Handbook of Public Administration (pp. 149-159). London: Sage Publications.

Insall, T. (2010) Haakon Lie, Denis Healey and the Making of an Anglo-Norwegian Special Relationship 1945-1951. Oslo: Oslo Academic Press.

IPEX (2018) The History of the EU Speakers Conference. Retrieved April 11, 2018, from http://www.ipex.eu/IPEXL-

WEB/dossier/files/download/082dbcc54af19e11014af1d1d7770017.do

Gunther, R., Montero, J. \& Linz, J. (Eds.) (2002). Political Parties: Old Concepts and New Challenges. Oxford: Oxford University Press.

Ingemann Johansen, A. (2017). Assessing the European Union's strategic capacity: The case of EUNAVFOR MED Operation Sophia. European Security, 26(4), 507-526.

Jacobs, K. \& Spierings, N. (2016). Social Media, Parties, and Political Inequalities. Basingstoke: Palgrave Macmillan.

Jäger, T., Oppermann, K., Höse, A. \& Viehrig, H. (2009). The salience of foreign affairs issues in the German Bundestag. Parliamentary Affairs, 62(3), 418-437.

Jansen, T. \& Van Hecke, S. (2011). At Europe's service: The origins and evolution of the European People's Party. Berlin-Heidelberg: Springer.

Janssen, T. (2016). A love-hate relationship: Far-right parties and the European Union. Brussels: Rosa Luxembourg Stiftung.

Jesse, E. (2018). Aufstehen prend modèle sur La France insoumise. Le Monde. Retrieved June 14, 2019 from https://www.lemonde.fr/idees/article/2018/09/22/aufstehen-prend-modelesur-la-france-insoumise_5358614_3232.html

Johansson, K.M. (1997). Transnational Party Alliances: Analysing the Hard-Won Alliance Between Conservatives and Christian Democrats in the European Parliament. Lund: Lund University Press.

Johansson, K.M. (1999). Tracing the employment title in the Amsterdam Treaty: Uncovering transnational coalitions. Journal of European Public Policy, 6(1), 85-101.

Johansson, K.M. (2002a). Party elites in multilevel Europe: the Christian democrats and the Single European Act. Party Politics, 8(4), 423-439.

Johansson, K.M. (2002b). Another road to Maastricht: the Christian Democrat coalition and the quest for European union. Journal of Common Market Studies, 40(5), 871-893.

Johansson, K.M. (2004). Toward a theory of federations of political parties in multilevel Europe: At the nexus of international relations and comparative politics. In P. Delwit, E. Külahci \& C. Van De Walle (Eds.), The Europarties: Organisation and Influence (pp. 17-43). Brussels: Editions de l'Université de Bruxelles.

Johansson, K.M. (2005). The alliance of European Christian democracy and conservatism: Convergence through networking. In W. Kaiser \& P. Starie (Eds.), Transnational European Union: Towards a Common Political Space (pp. 131-149). Abingdon: Routledge.

Johansson, K.M. (2009). The emergence of political parties at the European level: Integration unaccomplished. In S. Gustavsson, L. Oxelheim \& L. Pehrson (Eds.), How Unified is the European Union? European Integration between Visions and Popular Legitimacy (pp. 157-178). Berlin-Heidelberg: Springer.

Johansson, K.M. (2015). Europarties: A Research Note. Bonn: Zentrum für Europäische Integrationsforschung.

Johansson, K.M. (2016). Europarty influence and its limits: The case of the European People's Party and the Amsterdam Treaty. Journal of European Integration, 38(1), 79-94.

Johansson, K.M. (2017). The role of Europarties in EU treaty reform: Theory and practice. Acta Politica, 52(3), 286-305. 
Johansson, K.M. \& Raunio, T. (2005). Regulating Europarties: Cross-party coalitions capitalizing on incomplete contracts. Party Politics, 11(5), 515-534.

Johansson, K.M. \& Zervakis, P. (Eds.). (2002). European Political Parties between Cooperation and Integration. Baden-Baden: Nomos.

Joll, J. (2014[1955]). The Second International, 1889-1914. London: Routledge.

Judge, D. (1995). The failure of national parliaments? West European Politics, 18(3), 79-100.

Jun, U. (2018). Die SPD nach der Bundestagswabl 2017: Raus aus der GroKo, rein in die GroKo. Sankt Augustin/Berlin: Konrad Adenauer Stiftung.

Kaczyński, P. (2011). Paper tigers or sleeping beauties? National parliaments in the post-Lisbon European political system, CEPS Special Report. Brussels: Centre for European Policy Studies.

Kaiser, W. (2007). Christian Democracy and the Origins of European Union. Cambridge: Cambridge University Press.

Kaiser, W. (2008). Transnational networks in European governance: The informal politics of integration. In W. Kaiser, B. Leucht \& M. Rasmussen (Eds.), The History of the European Union: Origins of a Trans- and Supranational Polity 1950-1972 (pp. 24-45). Abingdon: Routledge.

Kaiser, W. (2010). Informal politics and the creation of the European Community: Christian democratic networks in the economic integration of Europe. In W. Kaiser, B. Leucht \& M. Gehler (Eds.), Transnational Networks in Regional Integration: Governing Europe 1945-1983 (pp.85-107). London: Palgrave Macmillan.

Kaiser, W. \& Starie, P. (2005). The European Union as a transnational political space: Introduction. In W. Kaiser \& P. Starie (Eds.), Transnational European Union: Towards a Common Political Space (pp. 1-14). Abingdon: Routledge.

Kaiser, W., Leucht, B. \& Gehler, M. (Eds.) (2010). Transnational Networks in Regional Integration: Governing Europe 1945-1983. London: Palgrave Macmillan.

Karlas, J. (2011). Parliamentary control of EU affairs in Central and Eastern Europe: Explaining the variation. Journal of European Public Policy, 18(2), 258-273.

Karlsson, C. \& Persson, T. (2018). The alleged opposition deficit in European Union politics: Myth or reality? Journal of Common Market Studies, 56(4), 888-905.

Katz, R. (1999). Representation, the locus of democratic legitimation and the role of the national parliaments in the European Union. In R. Katz \& B. Wessels (Eds.), The European parliament, the national parliaments, and European integration (pp. 21-44). Oxford: Oxford University Press.

Katz, D. \& Kahn, R. (1966). The Social Psychology of Organizations. New York: Wiley.

Katz, R. \& Mair, P. (1993). The evolution of party organizations in Europe: The three faces of party organization. American Review of Politics, 14(4), 593-617.

Katz, R. \& Mair, P. (1995). Changing models of party organization and party democracy the emergence of the cartel party. Party Politics, 1(1), 5-28.

Keck, M. \& Sikkink, K. (1999). Transnational advocacy networks in international and regional politics. International Social Science Journal, 51(159), 89-101.

Keohane, R. \& Nye, J. (1972). Transnational Relations and World Politics. Cambridge, MA: Harvard University Press.

Kesgin, B. \& Kaarbo, J. (2010). When and how parliaments influence foreign policy: The case of Turkey's Iraq decision. International Studies Perspectives, 11(1), 19-36.

Kieffer, G. \& Millar, D. (1979). Relations between the European Parliament and the national parliaments. In V. Herman \& R. Van Schendelen (Eds.), The European Parliament and the National Parliaments (pp. 32-45). Westmead: Saxxon House.

Kier, E. (1997). Imagining War: French and British Military Doctrine between the Wars. Princeton: Princeton University Press. 
Kiiver, P. (2006). The National Parliaments in the European Union: A Critical View on EU Constitutionbuilding. Biggleswade: Kluwer Law International.

King, G., Keohane, R. \& Verba, S. (1994). Designing Social Inquiry: Scientific Inference in Qualitative Research. Princeton: Princeton University Press.

Kinski, L. \& Crum, B. (2019). Transnational representation in EU national parliaments: Concept, case study, research agenda. Political Studies. https://doi.org/10.1177/0032321719848565.

Kirchheimer, O. (1966). The transformation of Western European party systems. In J. La Palombara \& M. Weiner (Eds.), Political Parties and Political Development (pp. 177-200). Princeton: Princeton University Press.

Klask, F. \& Krupa, M. (2017). Wie viel Schulz erträgt das Land?: Der SPD-Kanzlerkandidat geht auf Deutschlandtournee - und muss aufpassen, dass er nicht überdreht. Die ZEIT. Retrieved June 4, 2019, from https://www.zeit.de/2017/06/spd-kanzlerkandidat-martinschulz-wahlkampf-deutschland-tournee

Klingemann, H.D., Hofferbert, R. \& Budge, I. (1994). Parties, Policies, and Democracy. Boulder: Westview Press.

Klüver, H. \& Rodon, T. (2012). Explaining policy position choice of Europarties: The effect of legislative resources. British Journal of Political Science, 43(3), 629-650.

Knutelská, V. (2013). Cooperation among national parliaments: An effective contribution to EU legitimation? In B. Crum \& J.E. Fossum (Eds.), Practices of Inter-Parliamentary Coordination in International Politics: The European Union and Beyond (pp. 33-49). Colchester: European Consortium for Political Research Press.

Koole, R. (1996). Cadre, catch-all or cartel? A comment on the notion of the cartel party. Party Politics, 2(4), 507-523.

Kopecký, P. \& Mudde, C. (2002). The two sides of Euroscepticism: Party positions on European integration in East Central Europe. European Union Politics, 3(3), 297-326.

Kostadinova, P. \& Giurcanu, M. (2019). Europarties' election pledges and European Commission legislative priorities: An assessment of their overlap. Party Politics. https://doi.org/10.1177/1354068818820646

Kreilinger, V. (2013). The new inter-parliamentary conference for economic and financial governance. Notre Europe Policy Paper, 100. Retrieved from http://www.institutdelors.eu/wpcontent/uploads/2018/01/interparliamentaryconferenceecofinkreilingerne-jdioct2013.pdf

Kreppel, A. \& Hix, S. (2003). From "Grand Coalition" to left-right confrontation: Explaining the shifting structure of party competition in the European Parliament. Comparative Political Studies, 36(1-2), 75-96.

Kreppel, A. \& Tsebelis, G. (1999). Coalition formation in the European Parliament. Comparative Political Studies, 32(8), 933-966.

Kriesi, H., Grande, E., Lachat, R., Dolezal, M., Bornschier, S. \& Frey, T. (2006). Globalization and the transformation of the national political space: Six European countries compared. European Journal of Political Research, 45(6), 921-956.

Kröger, S. \& Bellamy, R. (2016). Beyond a constraining dissensus: The role of national parliaments in domesticating and normalising the politicization of European integration. Comparative European Politics, 14(2), 131-153.

Krook, M.L. (2010). Quotas for Women in Politics: Gender and Candidate Selection Reform Worldwide. Oxford: Oxford University Press.

Külahci, E. (2010). Europarties: Agenda-setter or agenda-follower? Social democracy and the disincentives for tax harmonization. Journal of Common Market Studies, 48(5), 1283-1306.

Kuilahci, E. (2012). Europeanisation and Party Politics: How the EU Affects Domestic Actors, Patterns and Systems. Colchester: ECPR Press. 
Külahci, E. \& Lightfoot, S. (2014). Governance, Europarties and the challenge of democratic representation in the EU: A case study of the Party of European Socialists. Acta Politica, 49(1), 71-85.

Kuper, E. (2006). Zwischen nationaler und internationaler Ebene: Transnationale Parteienkooperation in Europa als Forschungsproblem der Politikwissenschaft. In J. Mittag (Ed.), Politische Parteien und europäische Integration: Entwicklung und Perspektiven transnationaler Parteienkooperation in Europa (pp. 77-96). Essen: Klartext.

Kvale, S. \& Brinkmann, S. (2009). InterV iews: Learning the Craft of Qualitative Research Interviewing. Thousand Oaks: Sage.

Ladrech, R. (1993). Social democratic parties and EC integration. European Journal of Political Research, 24(2), 195-210.

Ladrech, R. (1997). Partisanship and party formation in European Union politics. Comparative Politics, 29(2), 167-185.

Ladrech, R. (2002). Europeanization and political parties: Towards a framework for analysis. Party Politics, 8(4), 389-403.

Ladrech, R. (2003). The Party of European Socialists: Networking Europe's social democrats. Journal of Policy History, 15(1), 113-129.

Ladrech, R. (2007). Europeanization and national party organization: Limited but appropriate adaptation? In T. Poguntke, N. Aylott, E. Carter, R. Ladrech \& K.R. Luther (Eds.), The Europeanization of National Political Parties: Parties and Organizational Adaptation (pp. 195-212). London: Routledge.

Ladrech, R. (2012). Party change and Europeanisation: Elements of an integrated approach. West European Politics, 35(3), 574-588.

Lancaster, K. (2017). Confidentiality, anonymity and power relations in elite interviewing: Conducting qualitative policy research in a politicised domain. International Journal of Social Research Methodology, 20(1), 93-103.

Larhant, M. (2005). La cooperation interparlementaire dans l'UE. Notre Europe Policy Paper, 16.

Laursen, F. \& S. Pappas (Eds.) (1995). The Changing Role of Parliaments in the European Union. Maastricht: European Institute of Public Administration.

Lavelle, A. (2008). The Death of Social Democracy: Political Consequences in the 21st Century. Aldershot: Ashgate.

Lees, C. (2018). The German Greens and the 2017 federal election: Between strategic calculation and real-world politics. German Politics, 27(1), 124-130.

Lenz, R. \& Engledow, J. (1986). Environmental analysis: The applicability of current theory. Strategic Management Journal, 7(4), 329-346.

Levy, J. (2008). Case studies: Types, designs, and logics of inference. Conflict Management and Peace Science, 25(1), 1-18.

Lightfoot, S. (2005). Europeanising Social Democracy? The Rise of the Party of European Socialists. Abingdon: Routledge.

Lightfoot, S. (2006). The consolidation of Europarties? The 'party regulation' and the development of political parties in the European Union. Representation, 42(4), 303-314.

Lindberg, B., Rasmussen, A. \& Warntjen, A. (2008). Party politics as usual? The role of political parties in EU legislative decision-making. Journal of European Public Policy, 15(8), 1107-1126.

Lipson, M. (2017). Organization theory and cooperation and conflict among international organizations. In R. Bierman \& J. Koops (Eds.), Palgrave Handbook of Inter-Organizational Relations in World Politics (pp. 67-96). Basingstoke: Palgrave Macmillan.

Lorenzo Rodriguez, J. \& Garmendia Madariaga, A. (2016). Going public against institutional constraints? Analyzing the online presence intensity of 2014 European Parliament election candidates. European Union Politics, 17(2), 303-323.

Luther, K.R. (2007). Structural adjustment and incumbent elite empowerment: Austrian parties' adaptation to European integration. In T. Poguntke, N. Aylott, E. Carter, R. Ladrech \& 
K.R. Luther (Eds.), The Europeanization of National Political Parties: Parties and Organizational Adaptation (pp. 26-52). London: Routledge.

Lupo, N. \& Fasone, C. (Eds.) (2016). Interparliamentary Cooperation in the Composite European Constitution. Oxford and Portland, OR: Hart.

Lupo, N. \& Griglio, E. (2018). The conference on stability, economic coordination and governance: Filling the gaps of parliamentary oversight in the EU. Journal of European Integration, 40(3), 358-373.

Mahoney, J. (2000). Strategies of causal inference in small-N analysis. Sociological Methods \& Research, 28(4), 387-424.

Mahoney, J. \& Goertz, G. (2006). A tale of two cultures: Contrasting quantitative and qualitative research. Political Analysis, 14(3), 227-249.

Mair, P. (1994). Party organizations: From civil society to the state. In R. Katz \& P. Mair (Eds.), How Parties Organize: Change and Adaptation in Party Organizations in Western Democracies (pp. 1 22). London: Sage Publications.

Mair, P. (1997). Party System Change: Approaches and Interpretations. Oxford: Oxford University Press.

Mair, P. (2000). The limited impact of Europe on national party systems. West European Politics, 23(4), 27-51.

Mair, P. (2007). Political parties and party systems. In P. Graziano \& M Vink (Eds.), Europeanization: New Research Agendas (pp. 154-166). Basingstoke: Palgrave Macmillan.

Mair, P. (2013). Ruling the Void: The Hollowing of Western Democracy. London: Verso.

Mair, P. \& Mudde, C. (1998). The party family and its study. Annual Review of Political Science, 1(1), 211-229.

Malang, T. (2019). Why national parliamentarians join international organizations. The Review of International Organizations, 14(3), 407-430.

Manwaring, R. \& Kennedy, P. (Eds.). (2017). Why the Left Loses: The Decline of the Centre-Left in Comparative Perspective. Bristol: Policy Press.

March, J. \& Olsen, J. (1984). The new institutionalism: Organizational factors in political life. American Political Science Review, 78(3), 734-749.

March, J. \& Simon, H. (1958). Organizations. New York: Wiley.

Marks, G. \& Steenbergen, M. (2002). Understanding political contestation in the European Union. Comparative Political Studies, 35(8), 879-892.

Marks, G., Wilson, C. \& Ray, L. (2002). National political parties and European integration. American Journal of Political Science, 46(3), 585-594.

Marschall, S. (2007). European parliaments in transnational organisations: Parliamentary cooperation beyond the European Union. Paper presented at the Conference "Fifty Years of Interparliamentary Cooperation", Berlin. Retrieved from https://www.swpberlin.org/fileadmin/contents/products/projekt_papiere/070829marschall_ks.pdf

Marschall, S. (2008). Transnational parliamentary assemblies and European security policy. In D. Peters, W. Wagner \& N. Deitelhoff (Eds.), The Parliamentary Control of European Security Policy, ARENA Report (7/08) (pp. 109-132). Oslo: ARENA Centre for European Studies.

Marsden, P., Cook, C. \& Knoke, D. (1996). American organizations and their environments: A descriptive overview. In A. Kalleberg, D. Knoke, P. Marsden \& J. Spaeth (Eds.), Organizations in America: Analyzing Their Structures and Human Resources Practices (pp. 45-66). Thousand Oaks: Sage.

Mastenbroek, E., Spendzharova, A. \& Versluis, E. (2014). Clawing back lost powers? Parliamentary scrutiny of the transposition of EU social policy directives in the Netherlands. West European Politics, 37(4), 750-768.

Mastenbroek, E., Zwaan, P., Groen, A., van Meurs, W., Reiding, H., Dörrenbächer, N. \& Neuhold, C. (2014). Engaging with Europe: Evaluating National Parliamentary Control of EU Decision Making after the Lisbon Treaty (Part I: Report of findings). Nijmegen: Radboud University. 
Maurer, A. \& Wessels, W. (2001). National Parliaments on their Ways to Europe. Losers or Latecomers? Baden-Baden: Nomos.

McDonnell, D. \& Werner, A. (2018). Respectable radicals: Why some radical right parties in the European Parliament forsake policy congruence. Journal of European Public Policy, 25(5), 747 763.

McElroy, G. \& Benoit, K. (2007). Party groups and policy positions in the European Parliament. Party Politics, 13(1), 5-28.

Meijers, M. (2017). Contagious Euroscepticism: The impact of Eurosceptic support on mainstream party positions on European integration. Party Politics, 23(4), 413-423.

Mello, P. (2018). National restrictions in multinational military operations: A conceptual framework. Contemporary Security Policy, 40(1), 38-55.

Mello, P. \& Peters, D. (2018). Parliaments in security policy: Involvement, politicisation, and influence. The British Journal of Politics and International Relations, 20(1), 3-18.

Meyer, J. \& Rowan, B. (1977). Institutionalized organizations: Formal structure as myth and ceremony. American Journal of Sociology, 83(2), 340-363.

Miklin, E. (2013). Inter-parliamentary cooperation in EU affairs and the Austrian parliament: Empowering the opposition? The Journal of Legislative Studies, 19(1), 22-41.

Miklin, E. (2017). Beyond subsidiarity: The indirect effect of the Early Warning System on national parliamentary scrutiny in European Union affairs. Journal of European Public Policy, 24(3), 366-385.

Miklin, E. \& Crum, B. (2011). Inter-parliamentary contacts of Members of the European Parliament: Report of a survey. RECON Online Working Papers, 8. Retrieved from http://www.reconproject.eu/main.php/RECON_wp_1108.pdf?fileitem $=50512020$

Miller, V. \& Ware, R. (1996). Keeping national parliaments informed: The problem of European legislation. The Journal of Legislative Studies, 2(3), 184-197.

Mitsilegas, V. (2007). Interparliamentary co-operation in EU Justice and Home Affairs. Paper presented at the Conference "Fifty Years of Interparliamentary Cooperation", Berlin. Retrieved from https://www.swpberlin.org/fileadmin/contents/products/projekt_papiere/070829mitsilegas_ks.pdf

Mittag, J. (Ed.) (2006). Politische Parteien und Europä̈sche Integration: Entwicklung und Perspektiven transnationaler Parteienkooperation in Europa. Essen: Klartext.

Mittag, J. (2011). Über Grenzen: Transnationale Parteienkooperationen. Moving the Social, 46, 5-8.

Möller, A. (2019). European election campaigns in Germany. Clingendael. Retrieved from https://www.clingendael.org/publication/european-election-campaigns-germany

Monroe, J. (2001). The Political Party Matrix: The Persistence of Organization. New York: State University of New York Press.

Montero, J.R. \& Gunther, R. (2002). Introduction: Reviewing and reassessing parties. In R. Gunther, J.R. Montero \& J. Linz (Eds.), Political Parties: Old Concepts and New Challenges (pp. 1-35). Oxford: Oxford University Press.

Moses, J. \& Knutsen, T. (2012). Ways of Knowing: Competing Methodologies in Social and Political Research. Basingstoke: Palgrave Macmillan.

Mudde, C. (2016). Populist radical right parties in Europe today. In J. Abromeit, B. Chesterton, \& Y. Norman (Eds.), Transformations of Populism in Europe and the Americas: History and Recent Tendencies (pp. 295-307). London: Bloomsbury Academic.

Mühlböck, M. (2012). National versus European: Party control over Members of the European Parliament. West European Politics, 35(3), 607-631.

Mundy, K. \& Murphy, L. (2001). Transnational advocacy, global civil society? Emerging evidence from the field of education. Comparative Education Review, 45(1), 85-126.

Natow, R. (2019). The use of triangulation in qualitative studies employing elite interviews. Qualitative Research. https://doi.org/10.1177/1468794119830077 
Negrine, R. (2007). The professionalisation of political communication in Europe. In R. Negrine, C. Holtz-Bacha, P. Mancini \& S. Papathanassopoulos (Eds), The Professionalisation of Political Communication (pp. 27-45). Bristol: Intellect.

Negrine, R., Holtz-Bacha, C., Mancini, P. \& Papathanassopoulos, S. (Eds). (2007). The Professionalisation of Political Communication. Bristol: Intellect.

Neuhold, C. \& De Ruiter, R. (2010). Out of REACH? Parliamentary control of EU affairs in the Netherlands and the UK. The Journal of Legislative Studies, 16(1), 57-72.

Neuhold, C. \& Högenauer, A.L. (2016). An information network of officials? Dissecting the role and nature of the network of parliamentary representatives in the European Parliament. The Journal of Legislative Studies, 22(2), 237-256.

Neunreither, K. (1994). The democratic deficit of the European Union: Towards closer cooperation between the European Parliament and the national parliaments. Government and Opposition, 29(3), 299-314.

Neunreither, K. (2005). The European Parliament and national parliaments: Conflict or cooperation? The Journal of Legislative Studies, 11(3-4), 466-489.

Niedermayer, O. (1983). Europdische Parteien? Zur gren₹iiberschreitenden Interaktion politischer Parteien im Rahmen der EG. Frankfurt: Campus Verlag.

Niedermayer, O. (1984). The transnational dimension of the election. Electoral Studies, 3(3), 235243.

Niedermayer, O. (2014). Immer noch eine „nationale Nebenwahl “? Die Wahl zum Europäischen Parlament vom 25. Mai 2014. Zeitschrift für Parlamentsfragen, 45(3), 523-546.

Nielsen, N. (2018). New EU party finance rules short circuit accountability. euobserver. Retrieved June 27, 2019 from https://euobserver.com/political/141637

Nordsieck, W. (2019). Parties and Elections in Europe: Parliamentary Elections and Governments since 1945, European Parliament Elections, Political Orientation and History of Parties. Retrieved from http://www.parties-and-elections.eu/index.html

Norton, P. (Ed.) (1996). National Parliaments and the European Union. London: Frank Cass.

Nováky, N. (2018). The road to Sophia: Explaining the EU's naval operation in the Mediterranean. European View, 17(2), 197-209.

Nulty, P., Theocharis, Y., Popa, S.A., Parnet, O. \& Benoit, K. (2016). Social media and political communication in the 2014 elections to the European Parliament. Electoral studies, 44, 429444.

Nye, J. (1974). Multinational corporations in world politics. Foreign Affairs, 53(1), 153-175.

O’Brennan, J. \& Raunio, T. (Eds.). (2007). National Parliaments Within the Enlarged European Union: From 'Victims' of Integration to Competitive Actors? Abingdon: Routledge.

Oliver, C. (1991). Network relations and loss of organizational autonomy. Human Relations, 44(9), 943-961.

Orenstein, M. \& Schmitz, H. (2006). The new transnationalism and Comparative Politics. Comparative Politics, 38(4), 479-500.

Organization for Security and Co-operation in Europe (2009) Elections to the European Parliament 47 June 2009: OSCE/ODIHR Expert Group Report. Warsaw: OSCE. Retrieved from https://www.osce.org/odihr/elections/eu/38680

Organstreitverfahren der Fraktion BUNDNIS 90/DIE GRUNEN im Deutschen Bundestag gegen die Bundesregierung (2015). Retrieved from https://www.gruenebundestag.de/fileadmin/media/gruenebundestag_de/themen_az/rechtspolitik/Antragssch rift-EUNAVFOR-MED_26_Oktober_2015.pdf

Ostermann, F., Böller, F., Christiansen, F.J., Coticchia, F., Fonck, D., Herranz-Surrallés, A. ... \& Raunio, T. (forthcoming). Voting on the use of armed force: Challenges of data indexing, classification, and the value of a comparative agenda. In D. Deschaux-Dutard (Ed.), Methods in Defence Studies: A Pluridisciplinary Handbook. London and New York: Routledge. 
Pahre, R. (1997). Endogenous domestic institutions in two-level games and parliamentary oversight of the European Union. Journal of Conflict Resolution, 41(1), 147-174.

Panebianco, A. (1988). Political Parties: Organization and Power. Cambridge: Cambridge University Press.

Papini, R. (1997). The Christian Democrat International. Lanham: Rowman \& Littlefield.

Parsons, T. (1956). Suggestions for a sociological approach to the theory of organizations. Administrative Science Quarterly, 1(1), 225-239.

Parti de Gauche (2018). Le Parti de Gauche s'adresse au PGE. Retrieved from https://www.lepartidegauche.fr/le-parti-de-gauche-sadresse-au-pge/

Party of European Socialists (2014a). Towards a new Europe: PES manifesto. Rome, Election Congress. Retrieved from https://www.pes.eu/export/sites/default/Downloads/PESDocuments/110001306_PES_Manifesto_UK.pdf_2063069299.pdf

Party of European Socialists (2014b). Successful launch of the first PES Training Academy in Vienna. Retrieved from https://www.pes.eu/en/news-events/news/detail/Successfullaunch-of-the-first-PES-Training-Academy-in-Vienna

Party of European Socialists (2015a). Presidency declaration ahead of the extraordinary EU Council meeting. Brussels, 23 April. Retrieved from https://www.pes.eu/export/sites/default/Downloads/Policy-

Documents/World/Presidency_declarationMigration-23042015.pdf_1449513791.pdf

Party of European Socialists (2015b). PES roadmap toward 2019. Budapest, 10th Congress. Retrieved from https://www.pes.eu/export/sites/default/Downloads/PESDocuments/FINAL_PES_Roadmap_2019-EN.pdf_1943303196.pdf

Party of European Socialists (2016). Ten points to tackle the refugee challenges. Retrieved January 15, 2018, https://www.pes.eu/export/sites/default/Downloads/PolicyDocuments/World/Paris_10_points_to_tackle_refugee_crisis_approved70716.pdf_242615993.pdf

Party of European Socialists (2018a). 2018 PES campaign camp Lisbon: Draft agenda. Retrieved June 15, from https://www.pes.eu/export/sites/default/galleries/Documentsgallery/Campaign-Camp-Lisbon-2018_12.11.2018.pdf_2063069299.pdf

Party of European Socialists (2018b). The PES to train 15000 activists for European elections. Retrieved from https://www.pes.eu/en/news-events/news/detail/The-PES-to-train15000-activists-for-European-elections/

Party of the European Left (n.d.). Evaluation using the questionnaires filled in by Member and observer parties for the 5th EL Congress. Retrieved from https://www.europeanleft.org/wp-content/uploads/2018/10/4_-_en_-_evaluation_and_evolution_document_final.pdf

Party of the European Left (2014). EL manifesto for the 2014 European elections: Escaping austerity, rebuilding Europe. Retrieved from http://dnpprepo.ub.rug.nl/618/1/pel2014.pdf

Party of the European Left (2016). Political document "Refound Europe: Create new progressive convergence". Berlin, 5th Congress. Retrieved from https://www.european-left.org/wpcontent/uploads/2018/10/1___en___political_document_el_-_congress_final.pdf

Party of the European Left (2018). Regarding the resolution of the Parti de Gauche to submit a motion on the expulsion of Syriza from the EL. Retrieved from https://www.europeanleft.org/903-2/

Party of the European Left (2019). Common platform for the 2019 European elections: For a progressive exit from the crisis. Retrieved from https://www.transformnetwork.net/fileadmin/user_upload/1.-en-electoral-platform-2019.pdf

Peabody, R., Hammond, S., Torcom, J., Brown, L., Thompson, C. \& Kolodny, R. (1990). Interviewing political elites. Political Science \& Politics, 23(3), 451-455. 
Pegan, A. \& Högenauer, A.L. (2016) The role of parliamentary administrations in interparliamentary cooperation. In N. Lupo \& C. Fasone (Eds.), Interparliamentary Cooperation in the Composite European Constitution (pp. 147-164). Oxford and Portland, OR: Hart.

Peñalver García, N. \& Priestley, J. (2015). The Making of a European President. Basingstoke: Palgrave Macmillan.

Pennings, P. (2006). An empirical analysis of the Europeanization of national party manifestos, 1960-2003. European Union Politics, 7(2), 257-270.

Pennings, P. (2017). Trends in the partisan positions on internationalism and defence in Europe, 1945-2016. Paper presented at Party politics of foreign and security policy in Europe, Amsterdam.

Peters, D. (2017). Actor, network, symbol: The interparliamentary conference on CFSP/CSDP. PACO Working Paper, 3. Retrieved from https:/ghum.kuleuven.be/ggs/research/paco/working-papers/pacowp-03-submitted.pdf

Peters, A. (2018). Between military deployment and democracy: Use of force under the German constitution. Journal on the Use of Force and International Law, 5(2), 246-294.

Peters, D. \& Wagner, W. (2010). Between military efficiency and democratic legitimacy: Mapping parliamentary war powers in contemporary democracies, 1989-2004. Parliamentary Affairs, 64(1), 175-192.

Peters, D., Wagner, W. \& Deitelhoff, N. (2010). Parliaments and European security policy: Mapping the parliamentary field. European Integration online Papers, 14(1), 1-25.

Peters, D., Wagner, W. \& Glahn, C. (2014). Parliamentary control of CSDP: The case of the EU's fight against piracy off the Somali coast. European Security, 23(4), 430-448.

Pfeffer, J. (1981). Management as symbolic action: The creation and maintenance of organizational paradigm. In L. Cummings \& B. Staw (Eds.), Research in Organizational Behavior (pp. 1-52). Greenwich: JAI Press.

Pfeffer, J. (1987). A resource dependence perspective on interorganizational relations. In M.S. Mizruchi \& M. Schwartz (Eds.), Intercorporate Relations: The Structural Analysis of Business (pp. 22-55). Cambridge: Cambridge University Press.

Pfeffer, J. (2003). Introduction to the classic edition. In J. Pfeffer \& G.R. Salancik, The External Control of Organizations: A Resource-Dependence Perspective (pp. xi-xxix). Stanford: Standford Business Classics.

Pfeffer, J. \& Salancik, G.R. (2003[1978]). The External Control of Organizations: A Resource-Dependence Perspective. Stanford: Stanford Business Classics.

Pinto-Duschinsky, M. (1991). Foreign political aid: The German political foundations and their US counterparts. International Affairs, 67(1), 33-63.

Plasser, F. \& Plasser, G. (2002). Global Political Campaigning: A Worldwide Analysis of Campaign Professionals and their Practices. Westport: Praeger.

Poguntke, T. (1998). Alliance 90/The Greens in East Germany: From vanguard to insignificance? Party Politics, 4(1), 33-55.

Poguntke, T. (2019). The German party system falling apart. In N. Bolin, K. Falasca, M. Grusell \& L. Nord (Eds.), Euroreflections: Leading Academics on the European Elections 2019 (p. 71). Sundsvall: Mittuniversitetet, Demicom.

Poguntke, T., Aylott, N., Ladrech, R. \& Luther, K.R. (2007). The Europeanisation of national party organisations: A conceptual analysis. European Journal of Political Research, 46(6), $747-$ 771.

Poguntke, T., Aylott, N., Carter, E., Ladrech, R. \& Luther, K.R. (Eds.) (2007). The Europeanization of National Political Parties: Parties and Organizational Adaptation. London: Routledge.

Pöhle, K. (1987). Le Parlement européen et les parlements nationaux. Revue du Marché Commun, 4(339). 
Pollak, J. \& Slominski, P. (2003). Influencing EU politics? The case of the Austrian parliament. Journal of Common Market Studies, 41(4), 707-729.

Political and Security Committee Decision (CFSP)2015/1772 concerning the transition by EUNAVFOR MED to the second phase of the operation (2015). Official Journal of the European Union, L258, 5-6.

Political and Security Committee Decision (CFSP)2016/1635 on the commencement of the capacity building and training of the Libyan Coast Guard and Navy by the European Union military operation in the Southern Central Mediterranean (EUNAVFOR MED operation SOPHIA) (2016). Official Journal of the European Union, L243, 11-12.

Political and Security Committee Decision (CFSP)2016/1637 on the commencement of the European Union military operation in the Southern Central Mediterranean (EUNAVFOR MED operation SOPHIA) contributing to the implementation of the UN arms embargo on the high seas off the coast of Libya (2016). Official Journal of the European Union, L243, 1415.

Polk, J., Rovny, J., Bakker, R., Edwards, E., Hooghe, L., Jolly, S. ...Zilovic, M. (2017). Explaining the salience of anti-elitism and reducing political corruption for political parties in Europe with the 2014 Chapel Hill Expert Survey data. Research \& Politics. https://doi.org/10.1177/2053168016686915

Ponterotto, J. (2006). Brief note on the origins, evolution, and meaning of the qualitative research concept thick description. The Qualitative Report, 11(3), 538-549.

Prosser, C. (2016). Dimensionality, ideology and party positions towards European integration. West European Politics, 39(4), 731-754.

Powell, W. \& DiMaggio, P. (Eds.) (1991). The New Institutionalism in Organizational Analysis. Chicago: University of Chicago Press.

Pridham, G. (1986). European elections, political parties and trends of internalization in community affairs. Journal of Common Market Studies, 24(4), 279-296.

Pridham, G. (1999a). Patterns of Europeanization and transnational party cooperation: Party development in Central and Eastern Europe. Paper presented at ECPR Sessions, workshop "European Aspects of Post-Communist Party Development", University of Mannheim. Retrieved from https://ecpr.eu/Filestore/PaperProposal/13d01896-aec9-4f22-bdbfbe07464ab4bd.pdf

Pridham, G. (1999b). Complying with the European Union's democratic conditionality: Transnational party linkages and regime change in Slovakia, 1993-1998. Europe-Asia Studies, 51(7), 1221-1244.

Pridham, G. (2008). European party cooperation and post-communist politics: Euroscepticism in transnational perspective. In A. Szczerbiak \& P. Taggart (Eds.), Opposing Europe: The Comparative Party Politics of Euroscepticism. Vol. 2, Comparative and Theoretical Perspectives (pp. 76103). Oxford: Oxford University Press.

Pridham, G. \& Pridham, P. (1979). The new European party federations and direct elections. The World Today, 35(2), 62-70.

Pridham, G. \& Pridham, P. (1981). Transnational Party Co-operation and European Integration: The Process Towards Direct Elections. Abingdon: Routledge.

Put, G.J., Van Hecke, S., Cunningham, C. \& Wolfs, W. (2016). The choice of Spitzenkandidaten: A comparative analysis of the Europarties' selection procedures. Politics and Governance, 4(1), 9-22.

Radaelli, C.M. (2000). Whither Europeanization? Concept stretching and substantive change. European Integration online Papers, 4(8).

Rasche, L. (2018). In troubled waters: What does the future hold for Operation Sophia? Policy Brief. Jacques Delors Institute. Retrieved from https://www.delorsinstitut.de/2015/wpcontent/uploads/2018/12/20181214_OperationSophia_Rasche.pdf 
Rasmussen, A. (2008). Party soldiers in a non-partisan community? Party linkage in the European Parliament. Journal of European Public Policy, 15(8), 1164-1183.

Rathbun, B. (2004). Partisan Interventions: European Party Politics and Peace Enforcement in the Balkans. New York: Cornell University Press.

Rathkolb, O. (2010). Brandt, Kreisky and Palme as policy entrepreneurs: Social democratic networks in Europe's policy towards the Middle East. In W. Kaiser, B. Leucht \& M. Gehler (Eds.), Transnational Networks in Regional Integration: Governing Europe 1945-83 (pp. 152-175). London: Palgrave Macmillan.

Rattinger, H., Roßteutscher, S., Schmitt-Beck, R. \& Weßels, B. (2011). Zwischen Langeweile und Extremen: Die Bundestagswabl 2009. Baden-Baden: Nomos.

Raube, K., Müftüler-Baç, M. \& Wouters, J. (Eds.) (2019). Parliamentary Cooperation and Diplomacy in EU External Relations. Cheltenham: Edward Elgar.

Raunio, T. (1999a). Always one step behind? National legislatures and the European Union, Government and Opposition, 34(2), 180-202.

Raunio, T. (1999b). Facing the European challenge: Finnish parties adjust to the integration process. West European Politics, 22(1), 138-159.

Raunio, T. (2000). Losing independence or finally gaining recognition? Contacts between MEPs and national parties. Party Politics, 6(2), 211-223.

Raunio, T. (2002). Why European integration increases leadership autonomy within political parties. Party Politics, 8(4), 405-422.

Raunio, T. (2005). Holding governments accountable in European affairs: Explaining crossnational variation. The Journal of Legislative Studies, 11(3-4), 319-342.

Raunio, T. (2009). National parliaments and European integration: What we know and agenda for future research. The Journal of Legislative Studies, 15(4), 317-334.

Raunio, T. (2011). The gatekeepers of European integration? The functions of national parliaments in the EU political system. Journal of European Integration, 33(3), 303-321.

Raunio, T. (2018[1997]). The European Perspective: Transnational Party Groups in the 1989-94 European Parliament. Abingdon: Routledge.

Raunio, T. \& Hix, S. (2000). Backbenchers learn to fight back: European integration and parliamentary government. West European Politics, 23(4), 142-168.

Raunio, T. \& Wagner, W. (2017). Towards parliamentarisation of foreign and security policy? West European Politics, 40(1), 1-19.

Regulation (EC) No 2004/2003 of the European Parliament and of the Council of 4 November 2003 on the regulations governing political parties at European level and the rules regarding their funding (2003). Official Journal of the European Union, L297, 1-4.

Regulation (EC) No 1524/2007 of the European Parliament and of the Council of 18 December 2007 amending Regulation (EC) No 2004/2003 on the regulations governing political parties at European level and the rules regarding their funding (2007). Official Journal of the European Union, L343, 5-8.

Regulation (EU, Euratom) No 1141/2014 of the European Parliament and of the Council of 22 October 2014 on the statute and funding of European political parties and European political foundations (2014). Official Journal of the European Union, L317, 1-27.

Regulation (EU, Euratom) 2018/673 of the European Parliament and of the Council of 3 May 2018 amending Regulation (EU, Euratom) No 1141/2014 on the statute and funding of European political parties and European political foundations (2018). Official Journal of the European Union, L114, 1-6.

Reh, C., Héritier, A., Bressanelli, E. \& Koop, C. (2013). The informal politics of legislation: Explaining secluded decision making in the European Union. Comparative Political Studies, 46(9), 1112-1142.

Reiding, H. \& Meijer, F. (2019). 'This time it's different': The European lead candidate procedure of 2014 and its historical background. Parliaments, Estates and Representation, 39(1), 64-79. 
Reif, K. \& Schmitt, H. (1980). Nine second-order national elections: A conceptual framework for the analysis of European election results. European Journal of Political Research, 8(1), 3-44.

Rettman, A. (2015). France, Germany, and Italy outline migrant plan. euobserver. Retrieved August 10, 2018, from https://euobserver.com/justice/129177

Rhodes, R. (1981). Control and Power in Central-Local Government Relations. Gower and Brookfield VT: Ashgate.

Rhodes, R. \& Dunleavy, P. (1995). Prime Minister, Cabinet and Core Executive. New York: Palgrave Macmillan; St. Martin's Press.

Riker, W. (1962). The Theory of Political Coalitions. New Haven: Yale University Press.

Risse, T. (2007). Transnational actors and world politics. In W. Zimmerli, M. Holzinger \& K. Richter (Eds.), Corporate Ethics and Corporate Governance (pp. 251-286). Berlin-Heidelberg: Springer.

Rohrschneider, R. \& Whitefield, S. (2016). Responding to growing European Union-skepticism? The stances of political parties toward European integration in Western and Eastern Europe following the financial crisis. European Union Politics, 17(1), 138-161.

Rohrschneider, R. \& Whitefield, S. (2017). Party positions about European integration in Germany: An electoral quandary? German Politics, 26(1), 83-103.

Rosén, G. (2015). EU confidential: The European Parliament's involvement in EU security and defence policy. Journal of Common Market Studies, 53(2), 383-398.

Rosén, G. \& Raube, K. (2018). Influence beyond formal powers: The parliamentarisation of European Union security policy. The British Journal of Politics and International Relations, 20(1), 69-83.

Rosenau, J. (1990). Turbulence in World Politics: A Theory of Change and Continuity. Princeton: Princeton University Press.

Rozenberg, O. \& Hefftler, C. (2015) Introduction. In C. Heffter, C. Neuhold, O. Rozenberg \& J. Smith (Eds.), The Palgrave Handbook of National Parliaments and the European Union (pp. 1-39). Basingstoke: Palgrave Macmillan.

Ruiz de Garibay, D. (2013). Coordination practices in the parliamentary control of Justice and Home Affairs agencies: The case of Europol. In B. Crum \& J.E. Fossum (Eds.) Practices of Inter-parliamentary Coordination in International Politics: The European Union and Beyond (pp. 87104). Colchester: ECPR Press.

Rules of procedure of the Inter-Parliamentary Conference for the Common Foreign and Security Policy and the Common Security and Defence Policy (2014). Retrieved from https://secure.ipex.eu/IPEXL-

$\mathrm{WEB} /$ conference $/$ getconference.do?type $=082 \mathrm{dbcc} 5420 \mathrm{~d} 8 \mathrm{f} 48014247 \mathrm{cca} 6 \mathrm{f} 04248$

Rules of procedure of the Interparliamentary Conference on Stability, Economic Coordination and Governance in the European Union (2015). Retrieved from https://secure.ipex.eu/IPEXL-

WEB/conference/getconference.do?type $=082 \mathrm{dbcc} 5420 \mathrm{~d} 8 \mathrm{f} 480142510 \mathrm{~d} 09574 \mathrm{e} 02$

Rules of procedure of the Conference of Parliamentary Committees for Union Affairs of Parliaments of the European Union (2011). Official Journal of the European Union, C229, 1-6.

Saalfeld, T. (2005). Deliberate delegation or abdication? Government backbenchers, ministers and European Union legislation. The Journal of Legislative Studies, 11(3-4), 343-371.

Saidel, J. (1991). Resource interdependence: The relationship between state agencies and nonprofit organizations. Public Administration Review, 51(6), 543.

Salm, C. (2016) Transnational Socialist Networks in the 1970s European Community Development Aid and Southern Enlargement. Basingstoke: Palgrave Macmillan.

Sartori, G. (2005[1976]). Parties and Party Systems: A Framework for Analysis. Colchester: ECPR Press.

Sartori, G. (2005). Party types, organisation and functions. West European Politics, 28(1), 5-32. 
Schakel, A. (2018). Rethinking European elections: The importance of regional spillover into the European electoral arena. Journal of Common Market Studies, 56(3), 687-705.

Scharpf, F. (1994). Community and autonomy: Multi-level policy-making in the European Union. Journal of European Public Policy, 1(2), 219-242.

Scharpf, F. (2001). Notes toward a theory of multilevel governing in Europe. Scandinavian Political Studies, 24(1), 1-26.

Schlesinger, J. (1984). On the theory of party organization. The Journal of Politics, 46(2), 369-400.

Schmitt, H., Hobolt, S. \& Popa, S.A. (2015). Does personalization increase turnout? Spitzenkandidaten in the 2014 European Parliament elections. European Union Politics, 16(3), 347-368.

Schotter, A., Mudambi, R., Doz, Y. \& Gaur, A. (2017). Boundary spanning in global organizations. Journal of Management Studies, 54(4), 403-421.

Schuster, J. \& Maier, H. (2006). The rift: Explaining Europe's divergent Iraq policies in the runup of the American-led war on Iraq. Foreign Policy Analysis, 2(3), 223-244.

Schüttemeyer, S. (2009). The German politics lecture 2008. Deparliamentarisation: How severely is the German Bundestag affected? German Politics, 18(1), 1-11.

Schwabe, F. \& Heinrich, G. (2015). Pressemitteilung: Deutsch-italienische Parlamentarierinitiative ruft nach effektiver Seenotrettung. Retrieved from https://gabrielaheinrich.de/workspace/media/static/pressemitteilung-frank-schwabe-5537917b0a1ab.pdf

Schwabe, F., Marazziti, M. \& Heinrich, G. (2015). Europas Werte dürfen nicht im Mittelmeer untergehen! Retrieved June 17, 2018, from http://www.swen-schulz.de/wpcontent/uploads/2015/04/EU-Flüchtlingsaufruf-DE-Hintergrundinfos-MdB.pdf

Schwartz-Shea, P. \& Yanow, D. (2012). Interpretive Research Design: Concepts and Processes. New York: Routledge.

Scoffoni, G. (1992). Les relations entre le Parlement Européen et les parlements nationaux et le renforcement de la légitimité démocratique de la Communauté. Cabiers de Droit Europeéen, 28(2), 233-252.

Scott, J. (1999). Transnationalizing democracy promotion: The role of Western political foundations and think-tanks. Democratization, 6(3), 146-170.

Scott, W.R. (2003[1981]). Organisations: Rational, Natural and Open Systems. New Jersey: Prentice Hall.

Scott, J. \& Carrington, P.J. (2011). The SAGE Handbook of Social Network Analysis. London: Sage Publications.

Seawright, J. \& Gerring, J. (2008). Case selection techniques in case study research: A menu of qualitative and quantitative options. Political Research Quarterly, 61(2), 294-308.

Segert, D. (2002). The PDS: Regional party or a second social-democratic party in Germany? In A. Bozóki \& J. Ishiyama (Eds.), The Communist Successor Parties of Central and Eastern Europe (pp. 166-187). Armonk: M.E. Sharpe.

Senninger, R. (2017). Issue expansion and selective scrutiny: How opposition parties used parliamentary questions about the European Union in the national arena from 1973 to 2013. European Union Politics, 18(2), 283-306.

Senninger, R. \& Bischof, D. (2018). Working in unison: Political parties and policy issue transfer in the multilevel space. European Union Politics, 19(1), 140-162.

Shackleton, M. (1995). Interparliamentary cooperation and the 1996 intergovernmental conference. In F. Laursen \& S. Pappas (Eds.), The Changing Role of Parliaments in the European Union (pp. 165-184). Maastricht: European Institute of Public Administration.

Shackleton, M. (2017). Transforming representative democracy in the EU? The role of the European Parliament. Journal of European Integration, 39(2), 191-205.

Sjursen, H. (2011). Not so intergovernmental after all? On democracy and integration in European foreign and security policy. Journal of European Public Policy, 18(8), 1078-1095. 
Smith, E. (Ed.) (1996). National Parliaments as Cornerstones of European Integration. London: Kluwer Law International.

Smith, J. (1997). A Sense of Liberty: The History of the Liberal International 1947-1997. London: Liberal International.

Smith, J. (2001). Political parties in a global age. In D. Josselin \& W. Wallace (Eds.), Non-state Actors in World Politics (pp. 59-75). Basingstoke: Palgrave Macmillan.

Sozialdemokratische Partei Deutschlands (2009). Europamanifest der Sozialdemokratischen Partei Deutschlands für die Wahlen zum Europäischen Parlament 2009. Für Europa: Stark und sozial! Retrieved from http://library.fes.de/prodok/ip02017/europamanifest_2009_final.pdf

Sozialdemokratische Partei Deutschlands (2013a). Das Wir entscheidet: Das Regierungsprogramm 2013-2017. Retrieved from http://library.fes.de/pdffiles/bibliothek/downl/7758779/20130415_regierungsprogramm_2013_2017.pdf

Sozialdemokratische Partei Deutschlands (2013b). Die SPD klopft an: Von Tür zu Tür im neuen Stil. Retrieved from https://www.spd-bw.de/dl/2015_Wegweiser_Tuer-zu-Tuer.pdf

Sozialdemokratische Partei Deutschlands (2013c). Protokoll des ordentlichen Bundesparteitags der SPD. Leipzig. $\quad$ Retrieved from https://www.spd.de/fileadmin/Dokumente/Beschluesse/Bundesparteitag/Protokoll_des _Bundesparteitages_2013__Leipzig.pdf

Sozialdemokratische Partei Deutschlands (2014a). Europa eine neue Richtung geben: Wahlprogramm für die Europawahl am 25. Mai 2014. Retrieved from http:/ /library.fes.de/pdf-files/bibliothek/downl/7767555/wahlprogramm-data.pdf

Sozialdemokratische Partei Deutschlands (2014b). Eckpunkte der Kampagne zur Europawabl am 25. Mai 2014. Berlin: SPD-Parteivorstand.

Sozialdemokratische Partei Deutschlands [SPD] (2015, September 15). Keynote von Jan Larsson (Socialdemokraterna) auf dem Campaign Camp 2015 (englisch) [video file]. Retrieved from https://www.youtube.com/watch?v=Q1z0qvB890E

Sozialdemokratische Partei Deutschlands (2018). Protokoll des außerordentlichen Bundesparteitages der SPD. Wiesbaden. Retrieved from https://www.spd.de/fileadmin/Dokumente/Beschluesse/Bundesparteitag/Protokoll_des _ausserordentlichen_Parteitags_in_Wiesbaden_22.4.2018.pdf

Sozialdemokratische Partei Deutschlands (2019). Kommt zusammen und macht Europa stark! Wahlprogramm für die Europawahl am 26. Mai 2019. Retrieved from http://library.fes.de/pdf-files/bibliothek/downl/spd_europaprogramm_2019.pdf

Sprungk, C. (2010). Ever more or ever better scrutiny? Analysing the conditions of effective national parliamentary involvement in EU affairs. European Integration online Papers, 14(2).

Startin, N. \& Brack, N. (2016). To cooperate or not to cooperate? The European radical right and pan-European cooperation. In J. FitzGibbon, B. Leruth \& N. Startin (Eds.), Euroscepticism as a Transnational and Pan-European Phenomenon (pp. 42-59). London: Routledge.

Steinnes, K. (2008). Socialist party networks in northern Europe: Moving towards the EEC applications of 1967. In W. Kaiser, B. Leucht \& M. Rasmussen (Eds.), The History of the European Union: Origins of a Trans- and Supranational Polity 1950-1972 (pp. 93-109). Abingdon: Routledge

Street, J. (2012). Do celebrity politics and celebrity politicians matter? The British Journal of Politics and International Relations, 14(3), 346-356.

Strelkov, A. (2015). National Parliaments in the Aftermath of the Lisbon Treaty: Adaptation to the New Opportunity Structure' (Doctoral dissertation). Maastricht: Datawyse/Universitaire Pers Maastricht.

Strøm, K. (1990). A behavioral theory of competitive political parties. American Journal of Political Science, 34(2), 565-598. 
Strøm, K. \& Müller, W. (1999). Political parties and hard choices. In W. Müller \& K. Strøm (Eds.), Policy, Office, or Votes? How Political Parties in Western Europe Make Hard Decisions (pp. 1-35). Cambridge: Cambridge University Press.

Sturges, J. \& Hanrahan, K.J. (2004). Comparing telephone and face-to-face qualitative interviewing: A research note. Qualitative Research, 4(1), 107-118.

Suchman, M. (1995). Managing legitimacy: Strategic and institutional approaches. Academy of management review, 20(3), 571-610.

Swenden, W. \& Maddens, B. (2009). Introduction. Territorial party politics in Western Europe: A framework for analysis. In W. Swenden \& B. Maddens (Eds.), Territorial Party Politics in Western Europe (pp. 1-30). Houndmills: Palgrave Macmillan.

Szczerbiak, A. \& Taggart, P. (2008). Opposing Europe?: The Comparative Party Politics of Euroscepticism: Volume 2: Comparative and Theoretical Perspectives. Oxford: Oxford University Press.

Taggart, P. \& Szczerbiak, A. (2004). Contemporary Euroscepticism in the party systems of the European Union candidate states of Central and Eastern Europe. European Journal of Political Research, 43(1), 1-27.

Tans, O., Zoethout, C. \& Peters, J. (2007). National Parliaments and European Democracy: A Bottomup Approach to European Constitutionalism. Groningen: Europa Law Publishing.

Tenscher, J. (2013). First-and second-order campaigning: Evidence from Germany. European Journal of Communication, 28(3), 241-258.

Tenscher, J. \& Mykkänen, J. (2014). Two levels of campaigning: An empirical test of the partycentred theory of professionalisation. Political Studies, 62(1), 20-41.

Tenscher, J., Mykkänen, J. \& Moring, T. (2012). Modes of professional campaigning: A fourcountry comparison in the European parliamentary elections, 2009. The International Journal of Press/Politics, 17(2), 145-168.

Tenscher, J., Koc-Michalska, K., Lilleker, D., Mykkänen, J., Walter, A.S., Findor, A. ... \& Róka, J. The professionals speak: Practitioners' perspectives on professional election campaigning. European Journal of Communication, 31(2), 95-119.

Theiling, F. (2017). Tür-zu-Tür-App: Wie die SPD den Wahlkampf digitalisiert. Vorwärts. Retrieved June 4, 2019, from https://www.vorwaerts.de/artikel/tuer-tuer-app-spdwahlkampf-digitalisiert

Thomas, C. (2001a). Political Parties \& Interest Groups: Shaping Democratic Governance. Boulder: Lynne Rienner.

Thomas, C. (2001b). Toward a systematic understanding of party-group relations in liberal democracies. In C. Thomas (Ed.), Political Parties \& Interest Groups: Shaping Democratic Governance (pp. 269-291). Boulder: Lynne Rienner.

Thompson, J. (1967). Organizations in Action. New York: McGraw-Hill.

Timuş, N. (2014). Transnational party Europeanization: EPP and Ukrainian parties. Acta Politica, 49(1), 51-70.

Timuş, N. \& Lightfoot, S. (2014). Europarties: Between the processes of 'deepening' and 'widening'. Acta Politica, 49(1), 1-4.

Tordoff, L. (2000). The conference of European affairs committees: A collective voice for national parliaments in the European Union. The Journal of Legislative Studies, 6(4), 1-8.

Toshkov, D. (2016). Research Design in Political Science. London: Palgrave Macmillan.

Tushman, M. \& Scanlan, T. (1981). Boundary spanning individuals: Their role in information transfer and their antecedents. Academy of Management Journal, 24(2), 289-305

Van Biezen, I. \& Molenaar, F. (2012). The Europeanisation of party politics? Competing regulatory paradigms at the supranational level. West European Politics, 35(3), 632-656.

Van Biezen, I., Mair, P. \& Poguntke, T. (2012). Going, going,... gone? The decline of party membership in contemporary Europe. European Journal of Political Research, 51(1), 24-56.

Van den Dool (2019). Forum duwt ChristenUnie uit Europese politieke familie. NRC Handelsblad. $\quad$ Retrieved July 17, 2019, from 
https://www.nrc.nl/nieuws/2019/06/05/forum-duwt-christenunie-uit-europese-politiekefamilie-a3962696

Van Haute, E. (2016a). Conclusion. Green parties in Europe: Which family ties? In E. Van Haute (Ed.), Green Parties in Europe (pp. 315-324). Abingdon: Routledge.

Van Haute, E. (Ed.) (2016b). Green Parties in Europe. Abingdon: Routledge.

Van Hecke, S. (2009). Europeanization and political parties: The Partido Popular and its transnational relations with the European People's Party. International Journal of Iberian Studies, 22(2), 109-124.

Van Hecke, S. (2010). Do transnational party federations matter? (... and why should we care?). Journal of Contemporary European Research, 6(3), 395-411.

Van Hecke, S. (2012). Polity-building in the constitutional convention: Transnational party groups in European Union institutional reform. Journal of Common Market Studies, 50(5), 837 852.

Van Middelaar, L. (2016). The return of politics: The European Union after the crises in the eurozone and Ukraine. Journal of Common Market Studies, 54(3), 495-507.

Vanhoonacker, S. (2005). The institutional framework. In C. Hill \& M. Smith (Eds.), International Relations and the European Union (pp. 67-89). Oxford: Oxford University Press.

Vanhoonacker, S., Dijkstra, H. \& Maurer, H. (2010). Understanding the role of bureaucracy in the European security and defence policy: The state of the art. European Integration online Papers, 14(4).

Vantaggiato, F. (2019). Networking for resources: How regulators use networks to compensate for lower staff levels. Journal of European Public Policy, 26(10), 1540-1559.

Verbruggen, S., Christiaens, J. \& Milis, K. (2011). Can resource dependence and coercive isomorphism explain nonprofit organizations' compliance with reporting standards? Nonprofit and Voluntary Sector Quarterly, 40(1), 5-32.

Verger, C. (2018). Transnational lists: A political opportunity for Europe with obstacles to overcome. Notre Europe Policy Paper, 216. Retrieved from https://institutdelors.eu/wpcontent/uploads/2018/02/Transnationallists-Verger-Feb18.pdf.

Verzichelli, L. (2018). Degradable elites? Modes and factors of parliamentary turnover in Europe in the early twenty-first century. In L. Vogel, R. Gebauer \& A. Salheiser (Eds.), The Contested Status of Political Elites: At the Crossroads (pp. 101-121). London: Routledge.

Vestlund, N. (2017). Pooling administrative resources through EU regulatory networks. Journal of European Public Policy, 24(1), 61-80.

Von dem Berge, B. \& Poguntke, T. (2013). The influence of Europarties on Central and Eastern European partner parties: A theoretical and analytical model. European Political Science Review, 5(2), 311-334.

Radaelli, C.M. (2000). Whither Europeanization? Concept stretching and substantive change. European Integration online Papers, 4(8).

Rauh, C. (2015). Communicating supranational governance? The salience of EU affairs in the German Bundestag, 1991-2013. European Union Politics, 16(1), 116-138.

Rooyen, E. (2009). De Europeanisering van Belangengroepen en Politieke Partijen in Nederland 1990-2000 (Doctoral dissertation). Amsterdam: Pallas Publications.

Wagner, W. (2005). From vanguard to laggard: Germany in European Security and Defence Policy. German Politics, 14(4), 455-469.

Wagner, W. Conclusion: Who is coming? Attendance patterns in the NATO and WEU parliamentary assemblies. In B. Crum \& J.E. Fossum (Eds.), Practices of Inter-Parliamentary Coordination in International Politics: The European Union and Beyond (pp. 195-212). Colchester: ECPR Press.

Wagner, W. (2017). The Bundestag as a champion of parliamentary control of military missions. Sicherbeit und Frieden, 35(2), 60-65. 
Wagner, W., Herranz-Surrallés, A., Kaarbo, J. \& Ostermann, F. (2017). The party politics of legislative-executive relations in security and defence policy. West European Politics, 40(1), 2041.

Walter, A., Van der Brug, W. \& Van Praag, P. (2014). When the stakes are high: Party competition and negative campaigning. Comparative Political Studies, 47(4), 550-573.

Weick, K. (1979[1969]). The Social Psychology of Organizing (second edition). New York: AddisonWesley.

Weissenbach, K. (2010). Political party assistance in transition: The German 'Stiftungen' in subSaharan Africa. Democratization, 17(6), 1225-1249.

Wendler, F. (2016). Debating Europe in National Parliaments. London: Palgrave Macmillan.

Westlake, M. (1995). The European Parliament, the national parliaments and the 1996 Intergovernmental Conference. The Political Quarterly, 66(1), 59-73.

Westlake, M. (2016). Chronicle of an election foretold: The longer-term trends leading to the 'Spitzenkandidaten' procedure and the election of Jean-Claude Juncker as European Commission President. LEQS Paper, 102.

Whitaker, R. \& Lynch, P. (2014). Understanding the formation and actions of Eurosceptic groups in the European Parliament: Pragmatism, principles and publicity. Government and Opposition, 49(2), 232-263.

Wiegel, M. (2013). Deutsch-französisches Treffen: Steinbrück unterstützt Hollande. Frankfurter Allgemeine. $\quad$ Retrieved July 2019 3, from https://www.faz.net/aktuell/politik/ausland/deutsch-franzoesisches-treffen-steinbrueckunterstuetzt-hollande-12138706.html

Williams, P. (2002). The competent boundary spanner. Public administration, 80(1), 103-124.

Williams, C. \& Spoon, J. (2015). Differentiated party response: The effect of Euroskeptic public opinion on party positions. European Union Politics, 16(2), 176-193.

Winzen, T. (2010). Political integration and national parliaments in Europe. Living Reviews in Democracy, 2. Retrieved from https:/ethz.ch/content/dam/ethz/specialinterest/gess/cis/cis-

dam/CIS_DAM_2015/WorkingPapers/Living_Reviews_Democracy/Winzen.pdf

Winzen, T. (2012). National parliamentary control of European Union affairs: A cross-national and longitudinal comparison. West European Politics, 35(3), 657-672.

Winzen, T., De Ruiter, R. \& Rocabert, J. (2018). Is parliamentary attention to the EU strongest when it is needed the most? National parliaments and the selective debate of EU policies. European Union Politics, 19(3), 481-501.

Wolfs, W. (2017). EU party funding: A pro-European instrument to support Euroscepticism? OECD Global Anti-Corruption \& Integrity Forum. Retrieved from http://www.oecd.org/cleangovbiz/Integrity-Forum-2017-Wolfs-EU-Party-Funding.pdf

Wolinetz, S. (2002). Beyond the catch-all party: Approaches to the study of parties and party organization in contemporary democracies. In R. Gunther, J. Montero \& J. Linz (Eds.), Political Parties: Old Concepts and New Challenges (pp. 136-165). Oxford: Oxford University Press.

Wolkenstein, F., Senninger, R. \& Bischof, D. (2019). Party policy diffusion in the European multilevel space: What it is, how it works, and why it matters. Journal of Elections, Public Opinion, and Parties. https://doi.org/10.1080/17457289.2019.1666403.

Wonka, A. (2016). The party politics of the Euro crisis in the German Bundestag: Frames, positions and salience. West European Politics, 39(1), 125-144.

Wry, T., Cobb, J.A. \& Aldrich, H.E. (2013). More than a metaphor: Assessing the historical legacy of resource dependence and its contemporary promise as a theory of environmental complexity. The Academy of Management Annals, 7(1), 441-488.

Yordanova, N. \& Mühlböck, M. (2015). Tracing the selection bias in roll call votes: Party group cohesion in the European Parliament. European Political Science Review, 7(3), 373-399. 


\section{Annex 1 | List of interviews by case study}

\begin{tabular}{|c|c|c|}
\hline Interview & Affiliation of the interviewee & Interview place and date \\
\hline \multicolumn{3}{|c|}{ Case study on EUNAVFOR Med } \\
\hline Interview 1 & Two staff members in the Bundestag, Greens & Berlin, 11 December 2017 \\
\hline Interview 2 & Staff member in the Bundestag, the Left & Berlin, 11 December 2017 \\
\hline Interview 3 & MP of the SPD & Berlin, 12 December 2017 \\
\hline Interview 4 & Staff member in the Bundestag, the Left & Berlin, 12 December 2017 \\
\hline Interview 5 & Staff member in the Bundestag, SPD & Berlin, 12 December 2017 \\
\hline Interview 6 & Parliamentary staff in the Bundestag & Berlin, 13 December 2017 \\
\hline Interview 7 & MP of the SPD & Berlin, 14 December 2017 \\
\hline Interview 8 & $\begin{array}{l}\text { Staff member in the European Parliament, } \\
\text { SPD }\end{array}$ & $\begin{array}{l}\text { Telephone interview, 12 January } \\
2018\end{array}$ \\
\hline Interview 9 & $\begin{array}{l}\text { Staff member in the central party office, the } \\
\text { Left }\end{array}$ & Berlin, 15 January 2018 \\
\hline Interview 10 & Staff member in the Bundestag, Greens & Berlin, 16 January 2018 \\
\hline Interview 11 & MP of the SPD & Berlin, 17 January 2018 \\
\hline Interview 12 & MP of the Left & $\begin{array}{l}\text { Answers to written questions via } \\
\text { e-mail, } 29 \text { January } 2018\end{array}$ \\
\hline Interview 13 & MP of the Greens & $\begin{array}{l}\text { Answers to written questions via } \\
\text { voice message, } 31 \text { July } 2018\end{array}$ \\
\hline Interview 14 & MP of the Greens & Skype interview, 27 August 2018 \\
\hline Interview 15 & Staff member in the Bundestag, SPD & Brussels, 28 August 2018 \\
\hline Interview 16 & MP of the PvdA (Dutch party) & The Hague, 19 October 2018 \\
\hline Interview 17 & Staff member in the Bundestag, SPD & Berlin, 2 May 2019 \\
\hline \multicolumn{3}{|c|}{ Case study on national and European elections } \\
\hline Interview 18 & $\begin{array}{l}\text { Staff member in the central party office, } \\
\text { SPD }\end{array}$ & Berlin, 17 March 2017 \\
\hline Interview 19 & $\begin{array}{l}\text { Staff member in the central party office, the } \\
\text { Left }\end{array}$ & Berlin, 11 December 2017 \\
\hline Interview 20 & Staff member of the European Green Party & Brussels, 28 November 2018 \\
\hline Interview 21 & $\begin{array}{l}\text { Staff member of the Rosa Luxembourg } \\
\text { Stiftung }\end{array}$ & Berlin, 10 December 2018 \\
\hline Interview 22 & $\begin{array}{l}\text { Staff member in the central party office, } \\
\text { PvdA (Dutch party) }\end{array}$ & Utrecht, 21 January 2019 \\
\hline Interview 23 & $\begin{array}{l}\text { Staff member of the Party of European } \\
\text { Socialists }\end{array}$ & $\begin{array}{l}\text { Telephone interview, } 14 \text { February } \\
2019\end{array}$ \\
\hline Interview 24 & $\begin{array}{l}\text { Staff member in the central party office, } \\
\text { GreenLeft (Dutch party) }\end{array}$ & Den Bosch, 27 February 2019 \\
\hline Interview 25 & $\begin{array}{l}\text { Staff member in the central party office, } \\
\text { Greens }\end{array}$ & Berlin, 5 March 2019 \\
\hline Interview 26 & Staff member in the central party office, & Leiden, 7 March 2019 \\
\hline
\end{tabular}


PvdA (Dutch party)

Interview 27 Staff member in the central party office, Berlin, 30 April 2019 SPD

Interview 28 Staff member in the central party office, Berlin, 2 May 2019 SPD

Interview 29 Staff member in the central party office,

Telephone interview, 2 May 2019 SPD

Interview 30 Staff member in the central party office, the Telephone interview, 23 May Left 2019

Interview 31 Staff member in the central party office, Skype interview, 27 May 2019 SPD

Interview 32 Staff member in the central party office,

Skype interview, 18 June 2019 Groen (Belgian party)

Interview 33 Staff member in the central party office, Telephone interview, 9 July 2019 Greens

Interview 34 Staff member in the central party office, Telephone interview, 11 July SPD 2019

\begin{tabular}{lll}
\hline General/other & & \\
\hline Interview 35 & $\begin{array}{l}\text { Staff member in the Bundestag, Greens } \\
\text { Interview 36 }\end{array}$ & $\begin{array}{l}\text { Staff member in the European Parliament, } \\
\text { S\&D Group }\end{array}$ \\
Interview 37 & $\begin{array}{l}\text { Staff member in the European Parliament, } 2016 \\
\text { EFD Group }\end{array}$ & $\begin{array}{l}\text { e-mail, 6 December } 2017 \\
\text { Brussels, 23 January } 2018\end{array}$ \\
Interview 38 & $\begin{array}{l}\text { Staff member in the European Parliament, } \\
\text { ALDE Group }\end{array}$ & Brussels, 23 January 2018 \\
Interview 39 & Local activist, PvdA (Dutch party) & Amsterdam, 4 January 2019 \\
\hline
\end{tabular}

Several interviewees are actually former staff members of the various parties or shifted positions between the Bundestag and the central party office. However, to safeguard their anonymity, the table does not show which interviewees this concerns. It rather reports the affiliation that was relevant to the interview. One interviewee was interviewed for both case studies. 


\section{Samenvatting}

\section{Met wat hulp van onze vrienden: Transnationale activiteiten van de SPD, Die Linke en Bündnis 90/Die Grünen in de Europese Unie}

Nationale politieke partijen zijn cruciaal in het democratische systeem van de Europese Unie (EU). Ze zijn de "voertuigen” (Strøm \& Müller, 1999, p. 1) tussen burgers en Europees beleid. In de media, bijvoorbeeld, zijn nationale politici zichtbaarder voor kiezers dan spelers op het Europese toneel (Boomgaarden et al., 2013). Tegelijkertijd zijn de verschillende niveaus van besluitvorming in de EU sterk met elkaar verweven. De EU is een 'meerlaags politiek systeem', waarin politieke partijen strategische mogelijkheden hebben. Onderzoek naar de transnationale activiteiten van nationale politieke partijen is daarom van groot belang om te begrijpen hoe democratie in de EU werkt.

Het is ingewikkeld om interacties tussen politieke partijen over grenzen heen te begrijpen. Aan de ene kant zijn er voordelen aan transnationale activiteiten. Partijen kunnen contact zoeken met Kamerleden uit andere EU-lidstaten om informatie te verkrijgen of proberen om standpunten van hun Europese politieke partij te beïnvloeden. Aan de andere kant zijn er beperkingen aan transnationale activiteiten. Contact leggen over grenzen heen kost bijvoorbeeld tijd en energie: wanneer leveren contacten iets op?

Dit proefschrift verkent 1) wat de transnationale activiteiten van nationale politieke partijen in Europese Zaken drijft en 2) onder welke omstandigheden nationale politieke partijen transnationale activiteiten ondernemen in Europese Zaken. Met andere woorden, het proefschrift beziet transnationale partij-activiteiten vanuit de spelers (waarom doen partijen wat ze doen?) en vanuit het systeem (welke factoren beïnvloeden de keuzes die partijen maken?).

Het proefschrift concentreert zich op de transnationale activiteiten van drie Duitse partijen aan de linkerkant van het politieke spectrum: de sociaal-democratische Sozialdemokratische Partei Deutschlands (SPD), de groene Bündnis 90/Die Grünen (de Groenen) en de radicaal-linkse Die Linke (Links). De focus ligt op de landelijke bureaus en Kamerfracties in de Bondsdag (2013-2017). De SPD, de Groenen en Links zijn interessante casussen voor een vergelijkende, kwalitatieve analyse van transnationale activiteiten. Ze zijn invloedrijk binnen hun fracties in het Europees Parlement, hebben een lange traditie van internationale samenwerking binnen hun partijfamilies en zijn belangrijk voor hun zusterpartijen vanwege de positie van Duitsland in Europa.

Omdat transnationale activiteiten plaatsvinden in de context van de onderwerpen waar politieke partijen mee bezig zijn, richt het onderzoek zich op twee 'dossiers'. Het eerste dossier is de European Naval Force Mediterranean (EUNAVFOR Med), de controversiële militaire operatie tegen mensensmokkelaars in de Middellandse Zee waaraan de meeste EU-lidstaten deelnamen (2015-2020). De campagnes voor de verkiezingen voor de Bondsdag van 2013 en 2017, en voor het Europees Parlement van 
2014 en 2019 vormen het tweede dossier. Naast allerlei officiële publicaties, vormen veertig interviews met politici en stafleden de belangrijkste bron van het onderzoek.

\section{Resource dependence theory als theoretisch kader voor de transnationale activiteiten van politieke partijen in de EU}

In het proces van Europese integratie zijn veel platformen ontstaan voor samenwerking tussen partijen en parlementen in de EU. De belangrijkste zijn de Europese politieke partijen, fracties in het Europees Parlement, conferenties voor interparlementaire samenwerking en afdelingen voor internationale samenwerking van nationale partijen. Partijen hebben dus meerdere routes om samen te werken in een 'meerlaags speelveld'. Dat speelveld is complex: de verschillende platformen zijn met elkaar verbonden, maar hebben ook eigen regels en dynamieken. Daarom is het belangrijk dat onderzoek kijkt naar "de versmelting van verschillende patronen van interactie" (Johansson, 2004, p. 18).

Bestaand onderzoek heeft maar weinig aandacht voor die versmelting. Veruit de meeste studies beschrijven transnationale activiteiten 'van bovenaf': vanuit het perspectief van de afzonderlijke, formele platformen voor samenwerking. Door in plaats daarvan een perspectief 'van onderaf' te kiezen, draagt dit proefschrift bij aan kennis over de informele transnationale activiteiten van politieke partijen, en kennis over de strategische en politieke belangen die een rol spelen bij het leggen van transnationale contacten.

Om transnationale partij-activiteiten te verklaren, presenteert dit proefschrift twee overkoepelende argumenten op basis van Resource Dependence Theory (RDT) (Pfeffer \& Salancik, 2003[1978]). RDT komt uit de bestuurs- en organisatiewetenschap. Haar uitgangspunt is dat organisaties middelen uitwisselen met externe actoren om hun doelen te realiseren. Daarbij proberen organisaties zo goed mogelijk controle te houden op de mate waarin ze extern afhankelijk zijn en op de sociale verwachtingen van externe actoren. Met haar nadruk op de motieven van organisaties is RDT beter geschikt als theoretisch kader voor transnationale partij-activiteiten dan de concepten van Europeanisering en transnationalisme, waarop de meeste bestaande literatuur terugvalt.

Het eerste theoretische argument dat het proefschrift uiteenzet betreft de oorzaak van transnationale partij-activiteiten - in lijn met de eerste onderzoeksvraag. Nationale partijen in de EU zijn afhankelijk van externe middelen en kunnen contact zoeken met gelijkgezinde partijen om die afhankelijkheid te beheersen. Er zijn drie categorieën van afhankelijkheid van zusterpartijen, zowel op nationaal als Europees niveau, namelijk in relatie tot middelen om zoveel mogelijk stemmen te trekken (votes), om toegang te krijgen tot invloedrijke posities (office) en om beleid te realiseren (policy) (Strøm, 1990).

Het tweede argument betreft de mate waarin nationale partijen transnationale partijactiviteiten ondernemen - de tweede onderzoeksvraag van het proefschrift. Hier zijn drie categorieën van systeemfactoren belangrijk, namelijk 1) de positie van een partij in het nationale politieke systeem, bijvoorbeeld in de regering of in de oppositie; 2) het bestaan van (alternatieve) routes voor toegang tot externe middelen, zoals zusterpartijen die in de regering zitten; en 3) de mate van ideologische samenhang in de Europese partijfamilie. 
De drie Duitse partijen zijn verschillend wat betreft deze drie systemfactoren. De SPD was bijvoorbeeld onderdeel van de regeringscoalitie, terwijl Links en de Groenen in de oppositie zaten. En eerder onderzoek laat zien dat de zusterpartijen van de sociaaldemocratische SPD ideologisch dichter bij elkaar staan als het gaat over Europese integratie dan de zusterpartijen van de Groenen en Links, maar niet als het gaat over militaire interventie - dan liggen de sociaal-democratische partijen juist verder uit elkaar.

\section{Waarom nationale partijen (geen) transnationale activiteiten ondernemen in Europese Zaken}

De empirische bevindingen over de transnationale activiteiten van de SPD, de Groenen en Links in het kader van de twee 'dossiers' - EUNAVFOR Med en campagnes voor verkiezingen - zijn in lijn met de belangrijkste theoretische verwachtingen van het proefschrift en leiden ook tot een aantal nieuwe inzichten.

Drie bevindingen springen in het oog wat betreft de oorzaak van transnationale partij-activiteiten. Ten eerste, nationale partijen zoeken voornamelijk contacten binnen hun partijfamilie in het kader van hun doelstellingen op het nationale niveau. In het geval van verkiezingscampagnes, bijvoorbeeld, benadrukten respondenten het belang van transnationale activiteiten om expertise over campagnestrategieën en -tools te delen. Een belangrijke kanttekening is dat het belang van nationale doelstellingen ook karakteristiek is voor de twee dossiers die het proefschrift analyseert.

Ten tweede, als nationale partijen proberen om gezamenlijke middelen te realiseren met hun Europese partijfamilie - zoals gezamenlijke standpunten of campagnes - is dat meestal om te beantwoorden aan sociale verwachtingen. De SPD, de Groenen en Links hechtten meer belang aan gezamenlijke middelen voor verkiezingscampagnes dan voor EUNAVFOR Med. De partijen vonden het belangrijk om Europees te handelen in Europese verkiezingscampagnes, om zo te voldoen aan verwachtingen van Duitse kiezers en van zusterpartijen in de EU. Bij besluitvorming over EUNAVFOR Med hechtten de partijen minder normatief belang aan Europees handelen, met uitzondering van Links.

Ten derde, partijen hebben soms te maken met conflicterende verwachtingen over hun transnationale activiteiten. Sommige politici vonden het bijvoorbeeld belangrijk om aanwezig te zijn bij interparlementaire conferenties om te netwerken en democratische betrokkenheid te laten zien, maar die 'reisjes' waren soms moeilijk te combineren met prioriteiten in de Bondsdag. In het geval van Europese verkiezingscampagnes wilde de SPD het systeem van een gemeenschappelijke kandidaat behouden voor Duitse kiezers, maar sommige zusterpartijen wilden niet dat er zo'n 'Spitzenkandidat' zou komen.

De positie van een partij in het nationale politieke systeem is de belangrijkste verklarende systeemfactor voor de mate waarin de partij transnationale activiteiten onderneemt. Dit ligt ook in het verlengde van de bevinding dat transnationale activiteiten vaak plaatsvinden in het kader van nationale doelstellingen. Vooral de analyse van EUNAVFOR Med illustreert het belang van nationale politiek. De oppositiepartijen Links en de Groenen vonden transnationale activiteiten veel belangrijker dan de SPD. En 
waar Links vooral informatie zocht om de regering te kunnen bevragen op de inhoud van de operatie, zochten de Groenen vooral expertise over standpunten om controle te houden op besluitvormingsprocessen.

De vergelijking van de twee dossiers laat ook zien dat de factor van ideologische samenhang binnen de partijfamilie onderwerp-specifiek is. Dit blijkt vooral uit de verschillende praktijken van de SPD en Links in de twee dossiers. Over Europese integratie was bevoorbeeld veel verdeeldheid binnen de radicaal-linkse partijfamilie, wat het moeilijk maakte voor Links om multilateraal samen te werken met zusterpartijen tijdens verkiezingscampagnes. Maar waar het ging om militaire interventie was de partijfamilie eensgezinder en kon Links tot gemeenschappelijke posities komen.

Wat betreft routes voor toegang tot externe middelen zijn de bevindingen meer ambigu. De drie Duitse partijen hadden inderdaad vooral contact met 'succesvolle' zusterpartijen, bijvoorbeeld als ze zochten naar expertise voor hun verkiezingscampagnes. Politici en stafleden van de Groenen benoemden ook dat transnationale activiteiten over EUNAVFOR Med moeilijk waren omdat er weinig sterke groene partijen in de EU zijn. Links maakte vooral gebruik van persoonlijke contacten in niet-gouvernementele organisaties over EUNAVFOR Med. Tot slot was het hebben van eigen middelen soms een reden om niet samen te werken, zoals in het geval van verkiezingsprogramma's maar niet altijd, zoals voor campagnestrategieën.

Het verkennende karakter van dit onderzoek betekent dat de conclusies voorzichtig zijn. Het proefschrift analyseert daarom ook de bevindingen van een aantal andere studies naar transnationale partij-activiteiten in het licht van het resource dependence perspectief. De conclusies die in sommige van deze studies afwijkend zijn met de conceptuele lens die de auteur gebruikt, kunnen goed verklaard worden met RDT.

\section{Beperkingen, mogelijkheden en gevaren voor transnationale partij- activiteiten in de $\mathbf{E U}$}

De bevindingen hebben een aantal implicaties voor het debat over de democratische legitimiteit van de Europese Unie. Enerzijds illustreert het proefschrift de beperkingen van formele platformen voor samenwerking tussen partijen en parlementen, vooral wat betreft de interparlementaire conferentie Gemeenschappelijk Buitenlands- en Veiligheidsbeleid. Dit leidt tot nieuwe vragen, omdat in de literatuur de hoop bestaat dat interparlementaire conferenties democratie in de EU kunnen versterken.

Anderzijds ondersteunt de bevinding dat met name oppositiepartijen voordeel kunnen hebben van transnationale partij-activiteiten het meer optimistische idee dat er ook binnen nationale parlementen meer debat ontstaat over Europees beleid.

Tot slot laat het onderzoek zien dat nationale partijen informele netwerken nodig hebben voor hun transnationale activiteiten. Via hun informele contacten kunnen nationale partijen hun capaciteiten vergroten, bijvoorbeeld om de nationale regering te controleren in Europese Zaken of om zich aan te passen aan grote veranderingen in het electoraat. 


\section{Valorisation addendum}

Not only academics struggle with understanding what the nature of the European Union is and, more specifically, what the nature of democracy in the European Union is. So do national parliamentarians, officials in central party offices, and active members of political parties at the national level. And for them, being part of an organisation that neither has the means nor the time to extensively study the EU, understanding the 'nature of the beast' can be a daunting task. At the same time, the European Union has become an important part of national parties' work of debating and making policies for citizens.

In this so-called 'valorisation addendum', I first reflect on the societal and political relevance of the research on transnational party activities in the EU that this dissertation presents. I also mention to whom the results are relevant. Subsequently, I elaborate on how I disseminated the results of the research project.

\section{'Who cares and so what?' The societal and political relevance of the research project}

I have already reflected on some of the wider political implications of this research project in the introduction and conclusion of this book. In this valorisation addendum, I want to flag two further implications of the findings of this research project on the transnational activities of national political parties. One of these implications relates to the wider societal debate and the other relates to politics.

\section{It is vital to think through the practical implementation of democratic reforms in the European Union}

Let me start with the first, societal implication. The public debate on the democratic legitimacy of the European Union is often a theoretical, abstract debate. It is about organisational processes, individual institutions, the relations between a few institutions, or even the structure of the whole of institutions. Should the European Parliament have more or less power? Should national parliaments convene in a 'Second Chamber' of the European Union or should they 'claw' back lost powers? Yet importantly, while democratic representation and accountability take place through institutions, they do not take place by institutions as such. Rather, it is actual people - parliamentarians and staff who try to make sure that other people are represented and that some people are held accountable.

The findings of this dissertation show that it is highly important to take into account the practices of politicians and their staff in the debate about democracy in Europe. For instance, the idea of a 'Second Chamber' of the European Union in which national parliamentarians are represented may seem nice to experts or politicians who would like to see more involvement of national Members of Parliament at the European 
level, but it is an empty promise if in practice these parliamentarians do not have the incentives nor the time to make this Chamber a success. The research findings allow me to illustrate this point with two further examples.

First, there is an ongoing discussion about the desirability of transnational lists of Europarties in elections to the European Parliament (see Verger, 2018).43 Ultimately, having transnational lists would mean that citizens from any EU member state can vote for candidates from any EU member state. The Europarties, and in particular their member parties, would be responsible for compiling the lists. Regardless of whether this is a good idea normatively speaking, the findings of this dissertation suggest that neither national parties nor most Europarties are currently ready and able to implement fullfledged transnational lists. Europarties have little resources in comparison to their larger member parties; and while national parties may have positive experience with exchanging campaign expertise, experience with developing common positions is much more mixed.

Second, various observers have advocated more intensive inter-parliamentary cooperation between parliaments in the European Union, including both national parliaments and the European Parliament (e.g. Borońska-Hryniewiecka, 2015; Kreilinger \& Larhant, 2016). They hope that such cooperation strengthens the role that national parliaments play in EU affairs, which would enhance the quality of democratic representation in EU affairs. Yet the findings of this dissertation show that the creation of new institutions for inter-parliamentary cooperation does not mean that such conferences are also relevant in practice for national parties or individual parliamentarians. Some parliamentarians do see their value, but others find that they have little incentive to spend their time at inter-parliamentary meetings. It may help to give the conferences more 'teeth' in terms of formal capabilities, but underlying issues about the national priorities of parliamentarians remain.

This is not to say that societal discussions about the democratic legitimacy of the EU should be about what is possible rather than about what is desirable. The argument is rather that questions regarding the system of democratic accountability and representation in the EU cannot be 'fixed' with recourse to new institutions or legal processes only. This is because political engagement with new formal platforms does not naturally follow from the creation of these platforms. If poorly executed, such new institutions and processes can make the EU even more complicated to understand for national citizens and politicians alike - particularly if they do not have their anticipated effect as a result of poor functioning. This may reduce rather than increase trust and engagement.

The issue of institutional reform of the European Union seems to be high up on the European agenda again. This is not least the case in the context of the corona-crisis that has made some of the strengths and - more painfully - weaknesses of the current

43 In February 2018, a majority of the MEPs rejected the idea of a transnational list for the 2019 elections to the European Parliament. That list would have kept 46 of the 79 seats left empty by the United Kingdom after Brexit for a "pan-European list" (Barbière, 2018). 
system apparent, such as with regard to the difficulties to sort out inter-governmental conflicts. The new Commission of Ursula von der Leyen had already in summer 2019 announced a new 'Conference on the Future of the Europe', during which the Spitzenkandidaten system and transnational lists would be one of the two main "work strands" (European Commission, 2020). In these discussions, it is vital for those with a seat at the table to think through the practical viability and implementation of new - and old - ideas.

\section{The value of transnational party activities is not immediately obvious to national parties}

This brings me to the second, political implication of the research findings of this dissertation. That is, the value of spending time and energy on relations with 'sister' parties or with fellow parliamentarians in other EU member states is not immediately obvious. This is certainly the case for the Member of Parliament, who may have 'better' things to do for the citizens that she or he wants to represent. Why would one go through the long process of establishing long-term relationships abroad?

The findings of this research project do not only show that there is value to transnational party activities, but also show under what circumstances transnational contacts can be particularly helpful. For example, sister parties may have useful policy expertise or knowledge about details of European negotiations, especially if they occupy a position in government office. Or they may have experience with organising campaigns in the context of a highly polarised political debate. But also in the longer run, having an informal transnational network and having access to international meetings can help parliamentarians to become experts in their field and to get their message across beyond the national realm.

Beyond these opportunities for transnational party activities, the findings also point to a few threats. To start with, several interviewees spoke about national capitals and Brussels in terms of isolated 'bubbles'. Even when a mutual exchange of information exists between MEPs and MPs, relations may still be hampered by mutual misunderstanding of political dynamics 'at home' or in the European Parliament respectively. Moreover, and as the conclusion of the dissertation outlines, several parliaments - including the European Parliament - have witnessed a high turnover of parliamentarians. Given that international contacts require mutual trust, such high turnovers make the existence of informal networks fragile.

In short then, the findings of this research project may serve as an additional argument for national parties and parliamentarians to better establish the infrastructure for their transnational activities. This, in turn, may help political parties to better perform their roles in the multi-level playing field of the European Union. It is crucial that national parties play their part on that stage, as they still function as the most important "“transmission belts" (Lindberg et al., 2008, p. 1107) between citizens and EU policies.

Finally, one can identify some 'best practices' for the actual organisation of transnational party activities from the research results. Most importantly, national parties 
can benefit from establishing personal networks among sister parties, on which they can rely for informal exchanges. To facilitate this, some national parties have, for example, exchanged staff members between their own parliamentary groups in the national and in the European Parliament. This can additionally contribute to a better understanding of each other's 'bubbles'. Some Europarties have also taken up a role in establishing transnational party networks, such as by providing training and exchanges for young party activists from the various EU member states.

For national parliamentarians, it can be worthwhile to regularly attend interparliamentary conferences, and particularly the party family meetings at these conferences, so as to establish personal relationships with MPs or MEPs from other member states. The usefulness of party family meetings can be aided by contacting parliamentarians from sister parties prior to inter-parliamentary conferences, as this can help to align agendas and organise fringe meetings.

Regarding exchanges in the context of election campaigns, successful examples of mutual learning usually have two characteristics. Namely, 1) they concern the use of specific tools or campaign strategies and 2) they facilitate campaign staff to 'translate' learning to the own national context. This can, for example, be accomplished by having a campaigner contribute to the election campaign of a sister party for a longer period of time, but also by facilitating shorter term exchange between actual campaign experts. Finally, alongside meetings in person, digital tools and virtual platforms can help to establish fast and comprehensive exchange of ideas and campaign material. In the context of European election campaigns, Europarties would do well to create such exchanges at an early stage.

\section{Dissemination of research findings}

I have shared the results of this research project with others in various ways. First, and foremost, the interviews with parliamentarians and with staff of parliaments and political parties has been an important avenue for dissemination as such. For some interviewees, it was interesting to hear insights from me about practices in other parties or parliaments. For others, the interview provided an opportunity on their own practices in transnational party activities - or the absence of such activities - in the European Union. Indeed, the phrase I perhaps most commonly heard was "we could do more".

Second, I have shared my research findings at various conferences and events. These include the DIA Graduiertenkolleg 'Conflict and Cooperation in Europe' in (Amsterdam, 2016), the NIG Research Colloquium 'International and EU Governance' (the Hauge, 2017), the ACCESS Europe workshop 'Party Politics of Foreign and Security Policy in Europe' (Amsterdam, 2017), the ECPR General Conference (Hamburg, 2018), and the Politicologenetmaal (Antwerp, 2019).

Third, I have published about my research in various outlets. Two chapters of the dissertation have been turned into academic publications. Chapter 2 has been published as part of the edited volume Parliamentary Cooperation and Diplomacy in EU External Relations. 
The findings of chapter 5, along with part of the theoretical framework of chapter 3, will be published as part of a special issue in Foreign Policy Analysis (peer-reviewed). I have also previously contributed to research on the role of national parliaments in the EU in The Palgrave Handbook of National Parliaments and the European Union, in a research report for the Dutch lower house (Tweede Kamer) called Engaging with Europe, and as co-editor of a special issue on national parliaments in the Internationale Spectator. During the $\mathrm{PhD}$ project, I also contributed to the Horizon 2020 project EUENGAGE by carrying out a survey on engagement with EU affairs in the Dutch parliament. I have furthermore written several professional publications and blogs on national parliaments and politics in the EU, such as for De Hofvijver of the Dutch Montesquieu Institute, for Alliance Europa, and for EInternational Relations.

Fourth, there was an opportunity to engage directly with stakeholders during the organisation of the 'Maastricht Debate' with the candidates for the office of Commission President for the 2019 European elections. I contributed to the preparatory work of this debate and co-hosted a side-event in Maastricht during which young party representatives debated EU affairs. I had also substantially contributed to the organisation of the 'First European Presidential Debate' in Maastricht in 2014, for example by establishing and maintaining contact with the Europarties and by putting together a network of universities that held side-events.

Fifth, and finally, I have shared my insights into the politics of European Union affairs with the next generation of policy makers in my teaching in the BA and MA European Studies in Maastricht. This, for example, included lectures on the role of parliaments in the European Union; supervision of theses about how national parties engage with EU affairs; helping students to learn about qualitative research methods including interviews and case studies - in courses on research methods; and guiding students in drawing up recommendations for the European Commission at the Maastricht Student Forum in Brussels. 



\section{About the author}

Afke Groen (Wageningen, 1991) obtained a BA in International Relations and International Organization at the University of Groningen (cum laude) and an MSc in European Studies at Maastricht University. During her studies, she worked as a research assistant to several projects, including the Observatory of Parliaments after Lisbon and the Maastricht Centre for European Governance. She then took up a position as junior lecturer and junior researcher at the Faculty of Arts and Social Sciences (FASoS) in Maastricht, during which she contributed to a research project on the yellow card procedure for the Dutch Tweede Kamer.

While conducting the research for this dissertation as a $\mathrm{PhD}$ candidate, Afke taught extensively in the Bachelor in European Studies at FASoS. She also took on the role of faculty coordinator of the Basis Kwalificatie Onderwijs (BKO) and co-initiated the FASoS Teaching and Learning Blog. After completing her dissertation, she briefly worked as postdoctoral lecturer and wrote a case study on risk governance for the Horizon 2020 project RECIPES. Afke currently works as a researcher for the think tank Mr. Hans van Mierlo Stichting. 
